
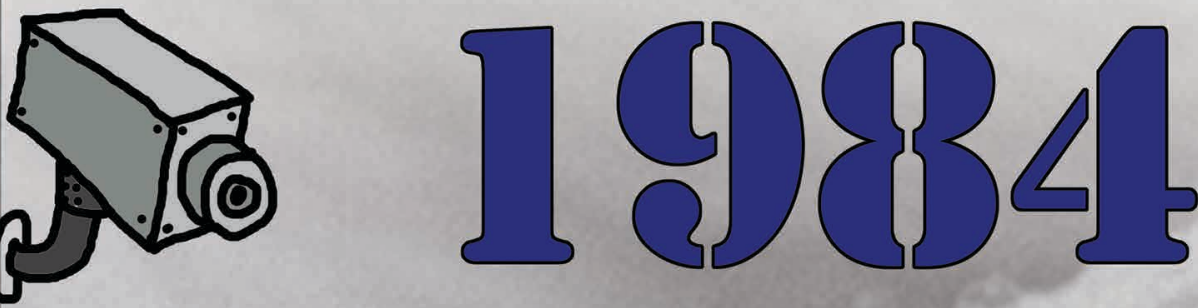

On Monitoring Cell Fate in Three-Dimensional Polymeric Scaffolds for Tissue Engineering Applications

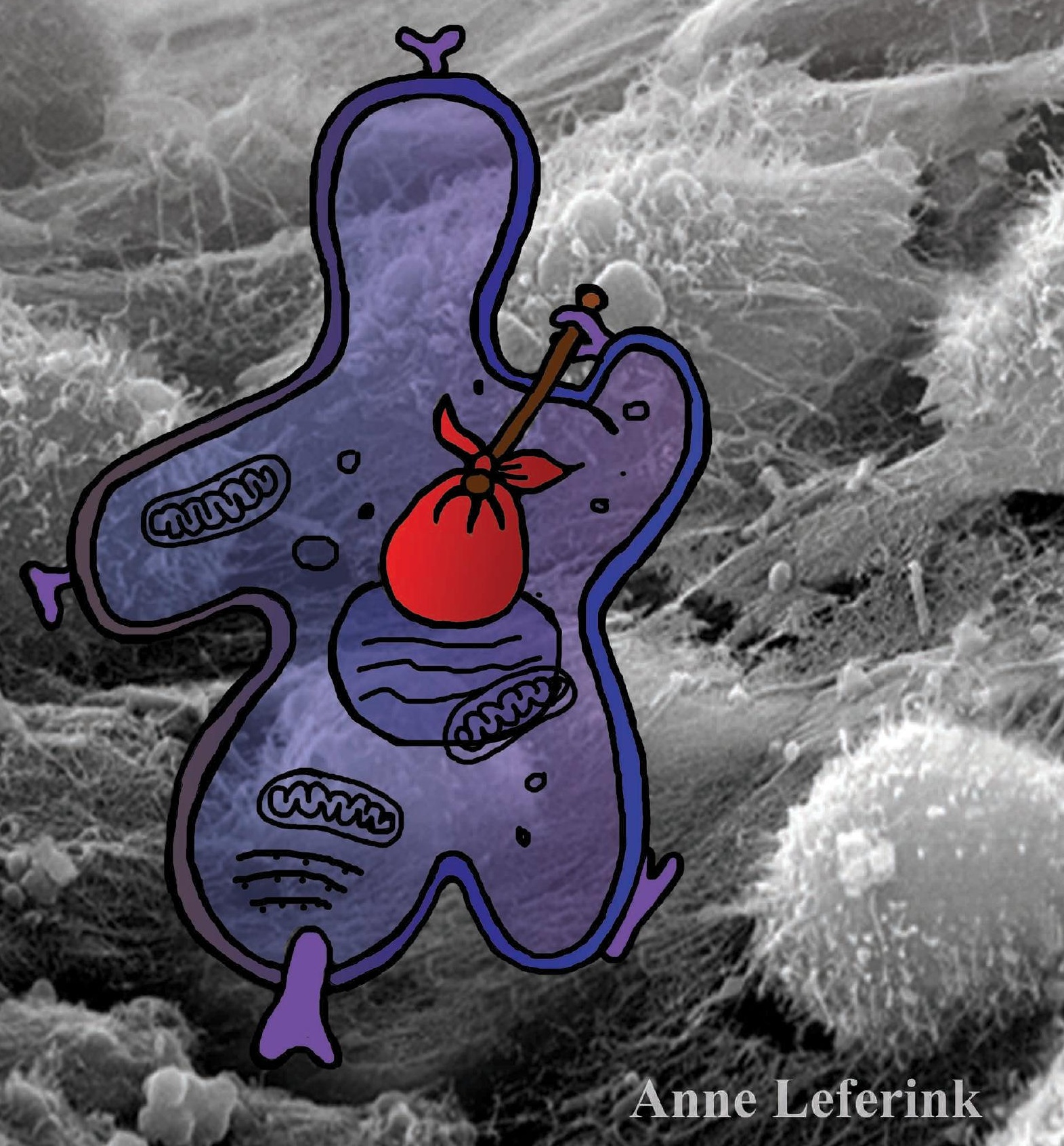




\section{4}

On Monitoring Cell Fate in Three-Dimensional Polymeric

Scaffolds for Tissue Engineering Applications

Anne Marijke Leferink

2014 


\section{Members of the Graduation Committee}

\section{Chairman:}

Prof. Dr. Ir. J. W. M. Hilgenkamp(University of Twente)

\section{Promoter:}

Prof. Dr. C. A. van Blitterswijk (University of Twente)

\section{Co-promoter:}

Dr. L. Moroni (University of Twente)

\section{Members:}

Prof. Dr. M. Karperien (University of Twente)

Prof. Dr. A. H. Velders (Wageningen University)

Prof. Dr. Ir. C. H. Slump (University of Twente)

Dr. Ir. J. M. J. Paulusse (University of Twente)

Dr. P. L. Granja (University of Porto)

\section{$-1984-$}

On Monitoring Cell Fate in Three-Dimensional Polymeric Scaffolds for Tissue Engineering Applications

Anne Marijke Leferink

PhD Thesis, University of Twente, Enschede, The Netherlands

This publication was supported by:

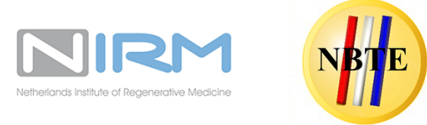

ISBN: 978-90-365-3693-6

DOI: $10.3990 / 1.9789036536936$

Copyright: A.M. Leferink 2014, Enschede, The Netherlands. Neither this thesis nor its parts may be reproduced without written permission of the author.

Cover design: Anne Leferink 


\title{
1984: \\ ON MONITORING CELL FATE IN \\ THREE-DIMENSIONAL POLYMERIC SCAFFOLDS \\ FOR TISSUE ENGINEERING APPLICATIONS
}

\section{DISSERTATION}

\author{
to obtain \\ the degree of doctor at the University of Twente, \\ on the authority of the rector magnificus, \\ Prof. Dr. H. Brinksma, \\ on the account of decision of the graduation committee, \\ to be publicly defended \\ on Thursday, July $3^{\text {rd }} 2014$ at 14.45 hours
}

by

Anne Marijke Leferink

Born on January $20^{\text {th }}, 1985$

in Enschede, the Netherlands 
This dissertation has been approved by:

Prof. Dr. C. A. van Blitterswijk (Promoter)

Dr. L. Moroni (Co-promoter) 


\section{Summary}

Tissue Engineering aims at restoring or regenerating damaged, lost or diseased tissues by combining patient-derived cells with soluble factors and/or synthetic or biological materials acting as so-called scaffolds. Depending on the strategy, these cells, factors and materials can be combined in vitro prior to implantation or in vivo directly. In both approaches quality control of the obtained construct remains a challenge. Most conventional methods to assess the success of a specific scaffold-based approach rely on destructive techniques which can only be executed at the end-point of an experiment or procedure. In the past decades, many advances have been made to assess the quality of constructs non-destructively. However, non-destructive methods cannot always reveal spatiotemporal information because most of these methods assess the tissue engineered construct as a bulk material.

Therefore, imaging methods are of interest to retrieve spatiotemporal information on cell behavior and tissue growth in a non-destructive manner. In chapter 2 of this thesis, the applicability of several clinically applied imaging techniques on the monitoring of opaque three-dimensional(3D) tissue engineered constructs is evaluated. Most microscopy techniques currently applied in tissue engineering have a limited penetration depth, a hurdle that clinically applied imaging techniques could aid to overcome. The best candidate for monitoring a tissue construct over time are imaging methods with a balance between lateral resolution, penetration depth, scanning time and tissue component distinguishing properties. However, most imaging methods aim at high penetration depths (in $\mathrm{cm}$ scale), simultaneously compromising the lateral resolution to limit scanning time.

Before testing candidate imaging methods, more insight in the cell behavior and tissue growth by conventional methods is required. Therefore, Part I of this thesis focusses on the current state-of-the-art in scaffold-based tissue engineering approaches. In chapter 3, seeding protocols to reduce human bone marrow stromal cell (hMSCs) losses in plotted 3D scaffolds are optimized. It is found that adjusting relatively 'simple' seeding parameters such as seeding volume and initial cell number, can significantly improve the cell seeding efficiency. In chapter 4 , the influence of dynamic culture conditions on cellular distribution and cellular phenotype is determined. The distribution and proliferation of fetal hMSCs on 3D rapid prototyped polymeric scaffolds improved upon convection culture compared to static culture. The cellular phenotype, however, is retained to a higher extend for convection culture than for static culture compared to monolayer culture in 2D. For adult hMSCs no beneficial effect is observed for convection culture compared to static culture. Chapter 5 introduces a 
novel micro-objects-based bottom-up approach which shows to overcome hurdles associated with nutrient deficiency and inhomogeneous cell distribution. It is shown that the shape, size and wettability of the scaffolding micro-objects plays an important role in the cell-guided assembly of the objects. Subsequently, chapter 6 describes the differentiation capacity of hMSCs on three distinct scaffold types and compares the results to the differentiation potential in $2 \mathrm{D}$ culture. It is shown that soluble-factor induced differentiation of hMSCs was not inhibited nor promoted by the scaffolds' properties. After soluble factor removal most of the changes in mRNA expression levels found upon possible differentiation were lost and returned to comparable levels as for hMSCs cultured in non-inductive media.

In Part II of this thesis, the application of available candidate imaging methods on monitoring 3D polymeric scaffolds was investigated. In chapter 7, three Raman spectroscopy set-ups are introduced as potential methods to obtain functional information on the composition of extra-cellular matrix (ECM) in several culture conditions. Raman bands for collagen and proteoglycans are discriminated and the Raman quantification of the two components is compared with the results of conventional biochemical and histological analysis for hydroxy-proline and glycosaminoglycans, respectively. Single chondrocytes and chondrocyte aggregates were seeded on 3D scaffolds with the hypothesis that micro-aggregates would preserve the chondrogenic character of the cells to a higher extent. The normalized band-area ratios for proteoglycans, however, do not show any difference between these two conditions. Yet, normalized band-area ratios for collagen gradually decrease over time for single seeded cells, whereas microaggregates show an increase in collagen. In chapter 8, magnetic resonance imaging is applied on mm-scaled 3D tissue constructs. MRI related limitations with respect to automated image analysis to assess tissue growth are overcome by implementation of a free-of-charge post-imaging processing sequence. Histological analysis qualitatively confirms the results found after quantification of tissue distribution via image analysis. Chapter 9 aims at the optimization of a method to functionalize particles and fluorophores potentially applicable in several imaging techniques to retain (more) functional information on ECM formation and cell fate. A tool to distinguish collagen type-I from collagen type-II is of high interest for bone and cartilage tissue engineers. The successful detection of collagen type-I in this study, shows that conjugation of particles to antibodies via amines offers an easy and feasible chemistry to functionalize antibodies with several types of particles applicable in various imaging methods. Finally, chapter 10 discusses the main findings of each chapter by evaluating their current and expected implications for the field of tissue engineering. 


\section{Samenvatting}

In het vakgebied 'tissue engineering' richt men zich op het vervangen of regenereren van beschadigd, verloren of ziek weefsel. Hierbij wordt gebruik gemaakt van combinaties van patiënt-verkregen cellen met (groei)factoren en/of synthetische of biologische materialen die als zogenaamd 'scaffold' (lett. steiger) kunnen dienen. Afhankelijk van de strategie en toepassing kunnen deze cellen, factoren en materialen zowel in vitro vóór implantatie als direct in vivo gecombineerd worden. In beide benaderingen blijkt kwaliteitscontrole van het verkregen construct een uitdaging. Veel conventionele methoden om het succes van een bepaalde strategie te bepalen zijn destructief en kunnen daarom alleen op het eindpunt van een experiment of procedure worden uitgevoerd. In de afgelopen decennia hebben er veel ontwikkelingen plaatsgevonden om kwaliteitscontrole uit te voeren op niet-destructieve wijze. Helaas geven deze methoden zelden spatio-temporale informatie (in ruimte en tijd) doordat het gekweekte construct als één volume in zijn geheel wordt geanalyseerd. Beeldvormende technieken wekken daarom de laatste jaren de interesse van onderzoekers in de weefselregeneratie. Deze technieken zijn er in theorie toe in staat cel gedrag en weefselgroei op niet-destructieve wijze in drie-dimensies (3D) in beeld te brengen. In hoofdstuk 2 van dit proefschrift wordt de geschiktheid van diverse klinisch toegepaste beeldvormende technieken in het monitoren van niet-transparante 3D weefselconstructen, onder de loep genomen. Momenteel worden kwalitatieve analyses in weefselregeneratie onderzoek veelal uitgevoerd op microscopen die helaas vaak een beperkte penetratiediepte hebben. De beste kandidaat voor het volgen van de kwaliteit van een weefselconstruct, zijn beeldvormende technieken met een balans tussen laterale resolutie, penetratie diepte, scan-tijd en weefsel-onderscheidend vermogen. Helaas, blijken de klinisch toegepaste beeldvormende technieken vaak juist te veel gericht te zijn op grote penetratiedieptes (in de cm-schaal), met als gevolg dat de laterale resolutie, ter voorkoming van lange scantijden, niet toereikend is voor de analyse van kleinere (mm-schaal) gekweekte weefsels.

Voordat de toepasbaarheid van potentiële beeldvormende technieken getest kan worden, zal er door middel van gestandaardiseerde (destructieve) technieken, meer inzicht verkregen moeten worden in cel gedrag en weefselgroei. Daarom richt deel I van dit proefschrift zich op de state-of-the-art in weefselregeneratie strategieën waarbij scaffolds de basis vormen. In hoofdstuk 3 wordt de optimalisatie van protocollen om humane mesenchymale stromale beenmerg cellen (hMSCs) op 3D geprinte scaffolds te zaaien beschreven om zodoende het celverlies te reduceren. Door relatief simpele parameters zoals zaai-volume en initiëel cel-aantal aan te passen, kan een significante 
verhoging van de cel-zaai-efficiëntie worden bereikt. In hoofdstuk 4 wordt the invloed van een dynamisch kweek systeem op cel-distributie en phenotype bepaald. De distributie en proliferatie van foetale hMSCs op 3D geprinte scaffolds blijkt in het dynamische systeem verbeterd te zijn ten opzichte van de hMSCs op scaffolds in een statisch kweeksysteem. Bovendien wordt het cellulaire phenotype beter behouden in dynamische kweek. Voor hMSCs uit volwassenen is er geen positief effect op cel distributie en cellulair phenotype gevonden wanneer deze in een dynamisch systeem gekweekt worden. Hoofdstuk 5 introduceert een nieuwe aanpak om door middel van micro-objecten, via een deeltje voor deeltje opbouw strategie (bottom-up), de problemen geassocieerd met de aanvoer en afvoer van voedings- en afvalstoffen en beperkingen ten gevolge van inhomogene cel distributie te overwinnen. De vorm, grootte en contact-hoek waarde van de deeltjes blijken hierbij cruciaal in de manier waarop de deeltjes met cellen aggregeren. Vervolgens wordt in hoofdstuk 6 de differentiatiepotentiaal van hMSCs in drie verschillende scaffold-typen geanalyseerd en vergeleken met de potentiaal van dezelfde cellen wanneer ze in standaard kweek-condities in 2D worden gedifferentieerd. De differentiatie, geïnduceerd door groeifactoren of door andere in medium opgeloste factoren, blijkt hierbij niet door de eigenschappen van de scaffolds belemmerd of begunstigd te zijn. Wanneer de factoren worden verwijderd gaan de behaalde veranderingen in mRNA expressie waarden verloren tot een niveau vergelijkbaar met de waarden gevonden voor hMSCs gekweekt in niet-inductief medium.

In deel II van dit proefschrift wordt de toepassing van veelbelovende beschikbare beeldvormende technieken op het monitoren van 3D polymere scaffolds onderzocht. In hoofdstuk 7 worden drie Raman spectroscopy set-ups geïntroduceerd om functionele informatie te verkrijgen over de compositie van extracellulaire matrix (ECM) in verschillende kweekcondities. Raman pieken voor collageen en proteoglycanen zijn onderscheiden en na kwantificatie van deze twee componenten, zijn de resultaten bevestigd met behulp van biochemische en histologische analyse. Chondrocyten zijn als individuele cellen en als aggregaten op 3D geprinte scaffolds gezaaid met de hypothese dat cellen in micro-aggregaten hun functionele eigenschappen beter behouden. Met behulp van genormaliseerde piek-oppervlakte ratios voor proteoglycanen blijkt echter dat er geen verschil zichtbaar is voor cellen in deze twee zaai-condities. Daarentegen laten de ratios voor collageen een geleidelijke afname in de tijd zien voor individueel gezaaide cellen, terwijl de cellen gezaaid als micro-aggregaten een toename in collageen laten zien. In hoofdstuk 8 is magnetische resonantie beeldvorming (MRI) toegepast op 3D polymere scaffolds gekweekt met hMSCs. Beperkingen met betrekking tot het automatiseren van de kwantificatie van weefselgroei, zijn getracht te voorkomen door de implementatie van een post-scan beeld-verwerkings sequentie die uitgevoerd kan worden met gratis te verkrijgen software. Histologische analyse bevestigt de resultaten gevonden voor de identificatie en kwantificatie van weefseldistributie met behulp van de geïmplementeerde sequentie. Hoofdstuk 9 stelt zich ten doel een methode the optimaliseren om fluorescente of anders contrasterende deeltjes te functionaliseren. Deze deeltjes moeten potentieel toepasbaar zijn in diverse beeldvormende technieken om (meer) informatie te verkrijgen over ECM formatie en cel gedrag. Een methode om collageen type-I van collageen type-II te kunnen onderscheiden is van groot belang voor bot en kraakbeen onderzoekers. De succesvolle 
detectie van collageen type-I in deze studie toont aan dat de koppeling van deeltjes aan antilichamen via amine-groepen een eenvoudige en uitvoerbare chemie kan bieden om ook andere soorten antilichamen aan deeltjes te koppelen. Zodoende kan in theorie met behulp van diverse beeldvormende technieken inzicht in de compositie en locatie van gesynthetiseerd ECM verkregen worden. Afsluitend worden in hoofdstuk 10 de belangrijkste bevindingen bediscussiëerd en worden de huidige en verwachtte implicaties voor het vakgebied van de weefselregeneratie geëvalueerd. 


\section{Statements with the thesis}

\section{-1984- \\ On Monitoring Cell Fate in Three-Dimensional Polymeric Scaffolds for Tissue Engineering Applications}

Anne Marijke Leferink, 2014

1. One does not need to know how each single cell in a population evolved during culture to be able to predict how a group of cells will evolve during an additional culture period. this thesis

2. Any approach to monitor a $3 \mathrm{D}$ tissue engineered construct during culture will affect the tissue culture process. this thesis

3. Top-down tissue engineering approaches lack control over tissue morphogenesis. this thesis

4. Guvendiren and Burdick's (Current Opinion in Biotechnology, 2013) statement that there is increasing evidence of differences in stem cell function when cultured in 3D compared to $2 \mathrm{D}$ is true. However, with their conclusion that advanced 3D microenvironment systems are needed to both better understand stem cells in vitro and to realize their potential in vivo, they disregard the fact that the complexity of the in vivo situation will never be equalled in in vitro studies, even when those studies are designed in 3D. this thesis

5. In a video-interview with van Blitterswijk (Maastricht University, 2014) the human body is compared with a car, stating that if you repair your car, you do not recreate the original situation. He explains that if you want to repair the human body, you will always end up with something which is of lesser quality than evolution has prepared during millions of years.

As an engineer, this comparison between the human body and the car is easily understood. However, depending on the quality of the car, a repair or a replacement part can in some cases result in improved function and quality. The same counts for some individuals.

6. Biodegradability is often set as a requirement for a candidate biomaterial in tissue engineering approaches. However, a well-integrated implant does not need to be degraded if it can retain its function during the rest of the recipient's life-time.

7. Simplicity in tissue engineering approaches is the most pragmatic way forward. The value of recent trends to increase the complexity of tissue engineering approaches is overestimated when taking into account regulations involved in clinical translation.

8. In the book 1984 is stated: 'A human is just a cell, and the weariness of a cell is the vigor of the organism.'

However, a human is more than a cell or a clump of cells. The cells' ability to communicate within the human body gives rise to the existence of humans as vigorous organisms.

9. 'Statements' and 'scaffolds' can both be translated to Dutch as 'stellingen'. Yet the second group requires lesser thinking to obtain. 


\section{Table of Contents}

1 General Introduction 1

2 Monitoring cell fate and tissue growth in three-dimensional scaf$\begin{array}{ll}\text { folds for tissue engineering } & 7\end{array}$

2.1 Introduction . . . . . . . . . . . . . . . . . . . . . . 9 9

2.2 Scaffold-based tissue engineering . . . . . . . . . . . . . . . . . 10

2.2.1 Scaffold materials . . . . . . . . . . . . . . . 10

2.2.2 Scaffold fabrication methods . . . . . . . . . . . . 12

2.3 Imaging modalities . . . . . . . . . . . . . . . . . . . . . . . . 15

2.3.1 Electron-beam imaging . . . . . . . . . . . . . . . 16

2.3.2 Nuclear imaging . . . . . . . . . . . . . . . . . . . . 17

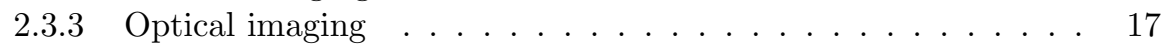

2.3 .4 Ultrasound(US) . . . . . . . . . . . . . . . . . . . 22

2.3.5 Photoacoustic tomography (PAT) and photoacoustic microscopy $(\mathrm{PAM}) \ldots \ldots \ldots . \ldots \ldots 22$

2.3.6 X-ray based micro-computed tomography (Micro-CT) . . . . . 23

2.3.7 Magnetic resonance imaging (MRI) . . . . . . . . . . . . . . . . 24

2.4 Discussion and future outlook . . . . . . . . . . . . . . . . . . 25

I Cell fate in 3D tissue engineered constructs 43

3 Increased cell seeding efficiency in bioplotted 3D PEOT/PBT scaf$\begin{array}{ll}\text { folds } & 47\end{array}$

3.1 Introduction . . . . . . . . . . . . . . . . . . . . . 49

3.2 Materials and Methods . . . . . . . . . . . . . . . . 50

3.2.1 Isolation of human bone marrow derived stromal cells . . . . . 50

3.2 .2 Scaffolds fabrication . . . . . . . . . . . . . . . 51

3.2.3 Cell seeding and culture on scaffolds . . . . . . . . . . . . . . . 52

3.2.4 CSE by DNA assay . . . . . . . . . . . . . . . 54

3.2.5 Cell loss by DNA assay . . . . . . . . . . . . . . . . . . 54

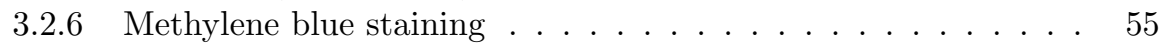

3.2.7 Scanning Electron Microscopy . . . . . . . . . . . . . . 55

3.2 .8 Statistical analysis . . . . . . . . . . . . . . . . 55

3.3 Results . . . . . . . . . . . . . . . . . . 56 
3.3.1 CSE versus initial cell number per seeding volume . . . . . . 56

3.3.2 CSE versus initial cell number in fixed seeding concentration . 56

3.3.3 CSE versus seeding volume per initial cell number . . . . . . . 57

3.3.4 CSE on scaffolds with various designs . . . . . . . . . . 57

3.3.5 CSE in static versus agitation with scaffolds on PS plate or in an agarose well . . . . . . . . . . . . . . 58

3.3.6 Cell adherence and morphology characterization . . . . . . . 59

3.4 Discussion . . . . . . . . . . . . . . . . . . . . . . . . . . . . . . . . . . . 59

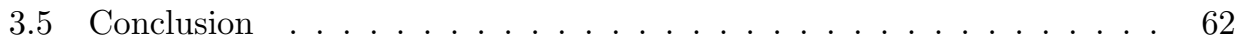

4 A comparative study on cell distribution and viability of fetal and adult human bone marrow stromal cells in a biaxial rotating vessel bioreactor after seeding on polymeric $3 \mathrm{D}$ rapid prototyped scaffolds 71

4.1 Introduction . . . . . . . . . . . . . . . . . . . . 73

4.2 Materials and Methods . . . . . . . . . . . . . . . . . . . 74

4.2.1 Isolation and culture of hfMSCs and haMSCs . . . . . . . . . . 74

4.2.2 Fabrication of PEOT/PBT scaffolds . . . . . . . . . . . . . . 75

4.2.3 Cell seeding on PEOT/PBT scaffolds . . . . . . . . . . . . 75

4.2.4 Bioreactor culture . . . . . . . . . . . . . . 76

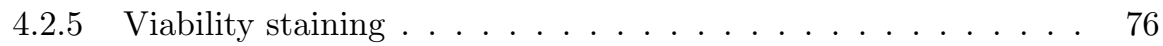

4.2 .6 DNA assay . . . . . . . . . . . . . . . . . . . 76

4.2.7 Hydroxyproline assay . . . . . . . . . . . . . . . . . . 77

4.2.8 Gene expression analysis of hfMSCs . . . . . . . . . . . . . . 77

4.2.9 Scanning electron microscopy (SEM) analysis . . . . . . . . . . 79

4.2.10 Methylene blue staining . . . . . . . . . . . . . . . . . . 79

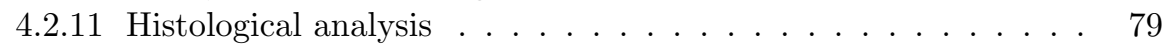

4.2 .12 Statistical analysis . . . . . . . . . . . . . . . . . . . . . . 80

4.3 Results........................ 80

4.3.1 Viability, distribution and gene expression profile of hfMSCs . 80

4.3.2 The cell adherence, distribution and gene expression profile of haMSCs .................... 84

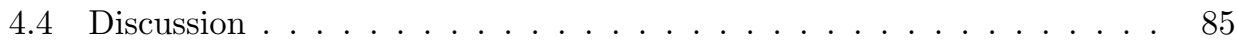

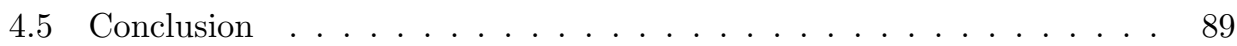

5 Engineered micro-objects as scaffolding elements in cellular building blocks for bottom-up tissue engineering approaches 103

5.1 Introduction . . . . . . . . . . . . . . . . . 105

5.2 Results and Discussion . . . . . . . . . . . . . . . . . . 107

5.3 Conclusions . . . . . . . . . . . . . . . . . . . 112

6 Differentiation capacity of human mesenchymal stromal cells cultured in three distinct types of 3D polymeric scaffolds 133

6.1 Introduction . . . . . . . . . . . . . . . . 135

6.2 Materials and Methods . . . . . . . . . . . . . . . . . . 137

6.2.1 Cell culture and culture media . . . . . . . . . . . . 137 
6.2.2 Fabrication of 3D scaffolds from PEOT/PBT by fused deposi-

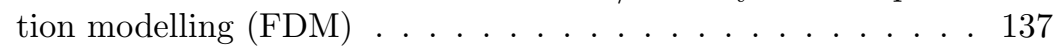

6.2.3 Fabrication of 3D scaffolds from PEOT/PBT by electrospinning (ES) . . . . . . . . . . . . . . . . . 138

6.2.4 Fabrication of SU-8 micro-objects . . . . . . . . . . . . . 138

6.2.5 Cell culture in 2D on Tissue Culture Polystyrene (TCPS) . . . 138

6.2.6 Cell culture on FDM-scaffolds . . . . . . . . . . . . . . . . . . 138

6.2.7 Cell culture on ES-scaffolds . . . . . . . . . . . . . . . . . . 139

6.2.8 Cell culture on micro-objects . . . . . . . . . . . . . . . 139

6.2.9 Gene expression analysis of hMSCs . . . . . . . . . . . . . 139

6.2 .10 DNA assay . . . . . . . . . . . . . . . . . 140

6.2 .11 ALP activity assay . . . . . . . . . . . . . . . . . . . . . 141

6.2 .12 GAG assay . . . . . . . . . . . . . . . . 141

6.2.13 Scanning electron microscopy (SEM) analysis . . . . . . . . . . 141

6.2 .14 Statistical analysis . . . . . . . . . . . . . . . . 141

6.3 Results.............................. 141

6.3.1 Differentiation potential of hMSCs in 3D scaffolds by qPCR . . 142

6.3.2 Differentiation potential of hMSCs in 3D scaffolds by protein expression analysis . . . . . . . . . . . . . 145

6.3.3 SEM analysis of ECM production after soluble factor induced

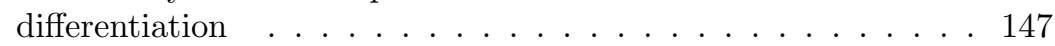

6.3.4 Loss of differentiated state of hMSCs in FDM- and ES-scaffolds upon soluble factor removal . . . . . . . . . . . . . . . . . 147

6.4 Discussion . . . . . . . . . . . . . . . . . . . 150

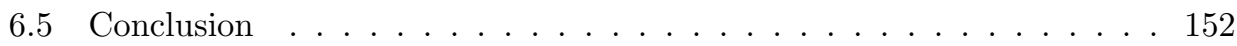

II Monitoring tissue engineered constructs $\quad 167$

7 Label-free Raman monitoring of extracellular matrix formation in $\begin{array}{ll}\text { three-dimensional polymeric scaffolds } & \mathbf{1 7 1}\end{array}$

7.1 Introduction . . . . . . . . . . . . . . . . . . . . 173

7.2 Materials and Methods . . . . . . . . . . . . . . . . . 173

7.2.1 Casting of agarose microwell arrays . . . . . . . . . . . . . . 173

7.2.2 Fabrication of PEOT/PBT scaffolds . . . . . . . . . . . . . 174

7.2.3 Isolation of bovine chondrocytes and cell culture . . . . . . . . 174

7.2.4 Cell seeding of PEOT/PBT scaffolds . . . . . . . . . . . . . . 175

7.2.5 Semi-Confocal Raman Microspectroscopy . . . . . . . . . . . . 176

7.2.6 Confocal Raman Microspectroscopy . . . . . . . . . . . . . . 176

7.2.7 Raman data analysis . . . . . . . . . . . . . . . . . . 177

7.2.8 Fiber-optic Raman spectroscopy and data analysis . . . . . . . 179

7.2 .9 GAG detection assay . . . . . . . . . . . . . . . . 179

7.2 .10 Hydroxyproline assay . . . . . . . . . . . . . . . . . . 179

7.2 .11 Histology . . . . . . . . . . . . . . . . . . . . 180

7.2.12 Scanning Electron Microscopy (SEM) . . . . . . . . . . . . . 180

7.2.13 Statistical analysis . . . . . . . . . . . . . . . . 180 
7.3 Results and Discussion . . . . . . . . . . . . . . . . . . . . 180

7.4 Conclusion . . . . . . . . . . . . . . . . . . 186

8 An open source image processing method to quantitatively assess tissue growth after non-invasive magnetic resonance imaging in human bone marrow stromal cell seeded 3D polymeric scaffolds

8.1 Introduction . . . . . . . . . . . . . . . . . . . . 197

8.2 Materials and Methods . . . . . . . . . . . . . . . . . . . 199

8.2.1 Isolation of human bone marrow derived stromal cells . . . . . 199

8.2.2 Fabrication of PEOT/PBT scaffolds . . . . . . . . . . . . . 199

8.2.3 Cell seeding of PEOT/PBT scaffolds . . . . . . . . . . . . . 199

8.2.4 MRI equipment and measurements . . . . . . . . . . . . . 200

8.2.5 Image processing and quantification . . . . . . . . . . . . . . 200

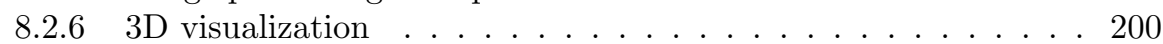

8.2.7 Methylene blue staining . . . . . . . . . . . . . . . . 201

8.2.8 Scanning Electron Microscopy (SEM) . . . . . . . . . . . . . . 201

8.2 .9 Histological analysis . . . . . . . . . . . . . . . . . . . . 201

8.3 Results . . . . . . . . . . . . . . . . . . . . 201

8.3.1 Detection of tissue on planar MRI images . . . . . . . . . . . . 201

8.3.2 Image processing and 3D visualization . . . . . . . . . . . . . 202

8.3.3 The effect of Endorem@contrast agent on the reliability of the 3D models . . . . . . . . . . . . . . . . . 202

8.3.4 Quantification of tissue distribution throughout the 3D scaffold 203

8.4 Discussion . . . . . . . . . . . . . . . . . 205

8.5 Conclusion . . . . . . . . . . . . . . . . 206

9 A future outlook $\quad 211$

9.1 Introduction . . . . . . . . . . . . . . . . . . 213

9.2 Cartilage and Bone . . . . . . . . . . . . . . . . . 213

9.3 Antibodies . . . . . . . . . . . . . . . . . . 216

9.4 Antibody conjugation chemistry . . . . . . . . . . . . 216

9.5 Materials and Methods . . . . . . . . . . . . . . . . 218

9.5.1 Ab-dye conjugation procedure . . . . . . . . . . . 218

9.5.2 Conjugate characterization ................ 219

9.5.3 Scaffold fabrication . . . . . . . . . . . . . . . . 219

9.5.4 Cell culture . . . . . . . . . . . . . . . . . 219

9.5.5 Immunostaining . . . . . . . . . . . . . . . . . 220

9.6 Results and Discussion . . . . . . . . . . . . . . . . . . . 222

9.6.1 Ab and dye concentration by nanodrop . . . . . . . . . . . 222

9.6.2 Cell culture . . . . . . . . . . . . . . . . . 222

9.7 Conclusion . . . . . . . . . . . . . . . . . . . 223

10 General Discussion $\quad 233$

$\begin{array}{ll}\text { Curriculum Vitae } & 239\end{array}$

List of Publications $\quad 241$ 


\section{Chapter 1}

\section{General Introduction}

Tissue Engineering is an interdisciplinary field that aims at restoring, repairing and regenerating lost, damaged or diseased tissues [1]. As there is a high need for methods to replace traditional tissue and organ transplantation approaches to overcome the currently faced problems of donor shortage and invasiveness of the procedure, tissue engineering holds the promise to offer a viable alternative to these conventional therapies [2]. In cartilage and bone engineering this need for alternative treatments to replace traditional tissue transplants is expected to increase in the coming decades due to the raising average age of the population [3].

Although many promising advances have been made in the past decades in in vitro tissue engineering, reproducibility and quality control remains a challenge $[4,5]$. Most methods to assess the success of a specific scaffold-based approach rely on destructive methods that can only be executed at the end-point of an experiment or procedure $[6,7]$. Information obtained by non-destructive methods often cannot reveal any spatiotemporal information because those methods treat the complete tissue engineered construct as a bulk material [8-10]. Whether this is generally important for all cell based approaches, real-time monitoring would be pivotal for stem cell based strategies to be able to understand the kinetics of cell differentiation [11]. Consequently, changes in environmental conditions could be actuated via the design of responsive scaffolds to steer and control this complex biological process [12, 13].

To be able to assess cell fate with novel approaches, the current state-of-the-art in scaffold-based tissue engineering approaches had to be assessed. Therefore, we first optimized seeding protocols to reduce human bone marrow stromal cell (hMSCs) losses in plotted three-dimensional (3D) scaffolds. Subsequently, we investigated the influence of dynamic culture condition on cellular distribution and cellular phenotype. Furthermore, we assessed the differentiation capacity of hMSCs on plotted 3D scaffolds and compared this with $2 \mathrm{D}$ cultures as well as two other scaffold systems. To explore the feasibility of continuous monitoring of (stem) cell activity in 3D constructs, the application of available imaging methods on traditional tissue engineering scaffolds was investigated. The main aim of this thesis was to assess cell behavior in $3 \mathrm{D}$ constructs, both by conventional destructive methods and novel non-destructive methods, to gain more insights in the challenges and potential of applying continuous monitoring to improve scaffold-based tissue engineering treatments in the future. 


\section{$-1984-$}

The main title of this thesis '1984' refers to the famous novel originally titled Nineteen Eighty-Four written by George Orwell in 1948 [14]. In short, the fiction novel describes a dictating political system called English Socialism in a province of the superstate Oceania. Some famous terms and concepts introduced in the novel such as Big Brother, telescreen and $2+2=5$ are still in everyday use since its publication in 1949. One of the central themes in the novel is the dictating and controlling omnipresent government which continuously monitors the behavior of all the members of the Outer-Party. Whenever a party-member is suspected of so-called thought crime or double-think, this person will be taken into custody and his mind will be re-set by brainwashing to be fully committed to the ideals and values of the regime. The monitoring of the outer-party members is conducted via telescreens, described as a sort of two-way television screens present in nearly every room, which continuously sends censured messages to the population. Via these same telescreens the government can visually track every human-being in the territory. Although, back in 1948 this technology seemed to be science-fiction, the similar concept of telescreens can these days be found in many living rooms.

The relation between the title and aims of this thesis, and the novel by George Orwell, can be found in this continuous monitoring. We hypothesize that by monitoring at single cell level, insights in the behavior and homogeneity of the population can be achieved, thus enabling the option to modulate biological signals and control cell activity. As a consequence of this monitoring, any cell suspected of 'thought-crime' meaning showing a different behavior - could be subjected to specific soluble factors or could even be eliminated. The novel presents the concepts of an omnipresent government and their ways of manipulating the population as an in-humanistic dystopia. We think that for the success of tissue engineering this same level of control on cells will be required. Yet, in the field of tissue engineering this control cannot be classified as a dystopia, since we do not consider cells as independently self-feeling organisms, even though some scientists interpret cells as such. We think that cells within a tissue engineered construct will only benefit from continuous monitoring, since it would enable scientists to adapt the culture conditions in such a way that cells remain viable and metabolically active.

\section{Outline of the thesis}

In Part I of this thesis the focus lays on scaffold-based cultures and the characterization of cell fate in these combinatorial approaches. In Part II, the fused deposition modeled scaffolds introduced in Part I are subjected to spectroscopic and imagingbased methods to investigate the feasibility of these methods as continuous tissue growth monitoring devices. In chapter 2, a concise review of conventional scaffold materials and fabrication techniques is given followed by an overview of available imaging technologies and their implications in the field of tissue engineering. Chapter 3 introduces fundamental parameters to take into consideration when using primary human bone marrow stromal cells with limited availability in combination with 3D 
fused deposition modeled scaffolds. Subsequently, chapter 4 continues on this line of reducing cell losses and improving cellular distribution throughout scaffolds by investigating the use of convection flow in a biaxial rotating bioreactor in comparison with static culture. In chapter 5, a novel bottom-up tissue engineering approach is proposed to overcome both the size limitations involved in scaffold-free tissue engineering approaches and the distribution challenges in top-down scaffolding approaches. In chapter 6 , the potential of hMSCs cultured on 3D scaffolds is further assessed by inducing differentiation into the chondrogenic and osteogenic lineage in different scaffold systems and studying the stability of such differentiated phenotype upon removal of morphogenetic signals.

In chapter 7 , the potential of label-free Raman spectroscopy in identifying and quantifying distinct extra cellular matrix components (ECM) in cartilage tissue engineering approaches is presented. Chapter 8 shows how magnetic resonance imaging (MRI) has a great potential in non-invasive label-free assessment of tissue growth. Furthermore, this chapter highlights the strength of post-imaging processing methods in retrieving quantitative data in 3D. Future advances in determination of cells functionality in 3D could be found in the application of immunolocalization via ECM specific antibodies. Therefore, chapter 9 concisely outlines the benefits and challenges of using antibodies in an analysis of the current state-of-the-art and the presentation of data in which probes developed in house are applied on 3D tissue engineered constructs. This thesis is finalized with a general discussion in chapter 10 on the main findings of every chapter and their current and expected implications for the field of tissue engineering. 


\section{References}

[1] Langer R, Vacanti JP. Tissue engineering. Science. 1993;260:920-6.

[2] Roberts SJ, Howard D, Buttery LD, Shakesheff KM. Clinical applications of musculoskeletal tissue engineering. British medical bulletin. 2008;86:7-22.

[3] Zhang L, Hu J, Athanasiou KA. The role of tissue engineering in articular cartilage repair and regeneration. Critical reviews in biomedical engineering. 2009;37:1-57.

[4] Carpentier B, Layrolle P, Legallais C. Bioreactors for bone tissue engineering. Int J Artif Organs. 2011;34:259-70.

[5] Tranquillo RT. The tissue-engineered small-diameter artery. Ann Ny Acad Sci. 2002;961:251-4.

[6] Mikos AG, Herring SW, Ochareon P, Elisseeff J, Lu HH, Kandel R, et al. Engineering complex tissues. Tissue engineering. 2006;12:3307-39.

[7] Fite BZ, Decaris M, Sun Y, Sun Y, Lam A, Ho CK, et al. Noninvasive multimodal evaluation of bioengineered cartilage constructs combining time-resolved fluorescence and ultrasound imaging. Tissue Eng Part C Methods. 2011;17:495-504.

[8] Santoro R, Krause C, Martin I, Wendt D. On-line monitoring of oxygen as a non-destructive method to quantify cells in engineered 3D tissue constructs. Journal of tissue engineering and regenerative medicine. 2011;6:696-701

[9] Appel AA, Anastasio MA, Larson JC, Brey EM. Imaging challenges in biomaterials and tissue engineering. Biomaterials. 2013;34:6615-30.

[10] Hong L, Peptan IA, Xu HH, Magin RL. Nondestructive evaluation of osteogenic differentiation in tissue-engineered constructs. Journal of Orthopaedic Research. 2006;24:889-97.

[11] Bagnaninchi PO, Drummond N. Real-time label-free monitoring of adipose-derived stem cell differentiation with electric cell-substrate impedance sensing. Proc Natl Acad Sci U S A. 2011;108:6462-7.

[12] Sapir Y, Polyak B, Cohen S. Cardiac tissue engineering in magnetically actuated scaffolds. Nanotechnology. 2014;25:014009.

[13] Chan G, Mooney DJ. New materials for tissue engineering: towards greater control over the biological response. Trends Biotechnol. 2008;26:382-92.

[14] Orwell G. Nineteen Eighty-Four. Knopf Doubleday Publishing Grou: Everyman's Library; 1992. ISBN: 9780679417392 


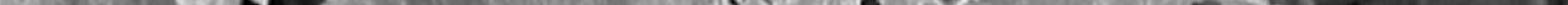




\title{
Chapter 2
}

\section{Monitoring cell fate and tissue growth in three-dimensional scaffolds for tissue engineering}

\author{
A. M. Leferink ${ }^{1}$, C. A. van Blitterswijk ${ }^{1,2}$, L. Moroni ${ }^{1,2}$ \\ ${ }^{1}$ Department of Tissue Regeneration, MIRA - Institute for Biomedical Technology and Technical \\ Medicine, University of Twente, Drienerlolaan 5, 7522 NB Enschede, The Netherlands ${ }^{2}$ Depart- \\ ment of Complex Tissue Regeneration, Faculty of Health, Medicine and Life Sciences, Maastricht \\ University, Maastricht, The Netherlands
}




\begin{abstract}
In the field of tissue engineering there is a need for methods that allow assessing the performance of tissue engineered constructs non-invasively in vitro and in vivo. To date, histological analysis is the golden standard to retrieve information on tissue growth, cellular distribution and cell fate on tissue engineered constructs after in vitro cell culture or on explanted specimens after in vivo applications. Yet, many advances have been made to optimize imaging techniques for monitoring tissue engineered constructs with a sub-mm or $\mu \mathrm{m}$ resolution. Many imaging modalities have first been developed for clinical applications in which a high penetration depth has been often more important than lateral resolution. Here, we have reviewed the current state-of-the art in several imaging approaches that have shown to be promising in monitoring cell fate and tissue growth upon in vitro culture. Depending on the aimed tissue type and scaffolds properties some imaging methods are more applicable than others. Optical methods are mostly suited for transparent materials such as hydrogels whereas magnetic resonance based methods are mostly applied to obtain contrast between hard and soft tissues regardless of their transparency. Overall, this review shows that the field of imaging in scaffold-based tissue engineering is developing at a fast pace and has the potential to overcome the limitations of destructive end-point analysis.
\end{abstract}

Keywords: Imaging, cell fate, tissue growth, scaffolds 


\section{$2.1 \quad$ Introduction}

The field of tissue engineering has been quickly growing for more than two decades. Numerous approaches for several applications have been under investigation and various challenges related to cell fate control, biocompatibility, and structural integrity of tissue engineered constructs among others, have been overcome. Currently, the quality of engineered tissue constructs is mostly assessed by conventional destructive methods such as histological analysis [1]. However, this approach results in the assessment of cell activity and produced extracellular matrix (ECM) only at the end of cultures, so that the culture period is still treated as a "black-box" with limited possibilities to steer culture conditions in a rationale manner. Data obtained by real-time non-destructive methods often lack spatiotemporal information since these methods treat a tissue engineered construct as a bulk material [2]. Therefore, there is a growing interest in novel methods to be able to non-destructively, and ideally non-invasively, assess the performance of tissue engineered constructs with a sufficient spatio-temporal resolution upon in vitro culture prior to implantation [3-5]. By gaining more insights in cell fate and tissue growth during culture, higher efficiencies and faster procedures could be realized.

Tissue engineering approaches can be generally divided into two main classes which consist of: 1) cell based approaches without the presence of any supporting material; 2) combinatorial approaches in which cells are introduced into biological or synthetic materials supporting proliferation or differentiation. In this review we will outline current methodologies and challenges with respect to the characterization of this second class of combinatorial scaffold-based tissue engineering approaches. We will specifically focus on the applicability of imaging modalities to assess cell fate when cultured on scaffolds fabricated of solid materials for musculoskeletal tissue engineering approaches.

Recent reviews have been published on studies that have addressed the importance of non-destructive assessment of tissue constructs' quality by the application of imaging methods [6-10]. However, the majority of these studies focus on scaffolds geometry characterization prior to cell seeding in vitro, or cell labeling and tracking after implantation in vivo [11]. These in vitro and in vivo studies unfortunately do no not all address other challenges faced when monitoring the scaffolds combined with cells in vitro. The limited penetration depth for most conventional microscopy techniques forms one of these major constraints [12]. Conventional imaging techniques such as laser confocal microscopy or transillumination microscopy require the use of thin samples or suffer from spatial resolution, respectively, to study the cellscaffold interactions, cellular distribution and proliferation during scaffold population [12]. So, the applicability of imaging modalities highly depends on the type of scaffolds used and the biological components to be detected. In this revieuw, we will first highlight some of the most used scaffold materials and fabrication methods and their limitations with respect to monitoring tissue growth, cell fate and/or cell metabolism. Subsequently, imaging modalities which are potential candidates to monitor these previously mentioned parameters will be introduced. 


\section{$2.2 \quad$ Scaffold-based tissue engineering}

In scaffold-based tissue engineering, biological or synthetic materials are processed into three-dimensional (3D) constructs or particles that enable cell growth within the final structure. Depending on the nature of these materials, the constructs can be hydrogel-based or composed of solids. Hydrogels mostly retain optical transparency whereas many solid scaffold materials can be auto-fluorescent, semi-transparent or opaque. These differences in optical properties obviously result in different challenges faced when monitoring cell fate, tissue growth and cell metabolism by imaging modalities. Here, we will shortly outline two classes of conventional scaffold materials followed by scaffold fabrication methods that have shown their relevance in musculoskeletal tissue engineering.

\subsubsection{Scaffold materials}

\section{Natural materials}

In many tissue engineering approaches natural materials such as bioceramics and biopolymers have gained interest because of their chemical properties, processability and availability [13]. Biological materials can be divided in several classes, namely, materials retrieved from inorganic materials or plants, from animal species (xenogeneic) or from allogeneic and autologous sources. Generally, when materials for scaffolds are retrieved from inorganic substances or a plant, a certain component is isolated and purified after which in most cases the macro-structure will be lost.

Materials of interest vary from relatively brittle and stiff materials such as ceramics to relatively soft materials such as biopolymers processed into hydrogels. Some commonly used bioceramics such as hydroxyapatites find their potential in bone tissue engineering because of their known osteoconductive and/or osteoinductive properties [14-17]. Biopolymers, which can be divided in polysaccharides, proteins and polyesters, are also of interest in several tissue engineering approaches [18]. For example in cartilage tissue engineering research, hydrogels composed of collagen, alginate, hyaluronic acid or chitosan, among others, are widely applied as ECM-mimetic materials [19-26]. Furthermore, silk, marine shells and corals have been used as sources for biological materials in several tissue engineering approaches [27-32]. Bioceramics are crystalline and therefore opaque materials, whereas biopolymers are semi-crystalline or fully amorphous permitting a certain degree of transillumination.

Decellularized ECM scaffolds from xenogeneic, allogeneic or autologous sources, are opted as promising non-immunogenic materials for several tissue engineering approaches since their composition mimics the native tissues to a great extent [33-36]. However, it is well-known that the structure of the native ECM may be modified or even disrupted in the decellularization process [37, 38]. Therefore, in soft tissue engineering, these obtained ECM components are mostly processed as a hydrogel [3942] which offers a matrix for cell encapsulation and permits cell fate monitoring by optical imaging modalities. In other works, some scaffold fabrication techniques such as electrospinning have been applied to regain cell-instructive structural elements of the native ECM after decellularization, which leads to the fabrication of nano-fiber meshes mimicking the structure of native ECM [43-45]. For musculoskeletal tissue en- 
gineering and especially bone tissue engineering, hard tissue replacements are favored which will require sufficient mechanical stability and structural integrity to sustain the loading conditions in the implantation site. Therefore, combinatorial approaches of synthetic materials with decellularized ECM have been investigated to retain both the native tissue properties of the ECM components and the mechanical properties of the scaffold material [46-48]. Several processes of decellularization and their tissue sources and applications are well reviewed elsewhere [49-52]. The optical properties of decellularized ECM are mostly determined by the type of tissue that was isolated. These properties are expected to be comparable with the native ECM, even though the removal of, for example, red-blood cells can change the color of the tissue, the resulting change in absorption coefficient is not expected to play a major role in the applicability of currently available imaging modalities.

\section{Synthetic materials and composites}

Synthetic materials represent a large class of widely used materials in tissue engineering approaches. Upon material synthesis, mechanical properties, surface chemistry and degradability can be tailored. Furthermore, synthetic materials are generally easily processed into scaffolds by various methods which will be outlined in the next section. Synthetic polymers have received considerable attention and are widely studied in cartilage and bone tissue engineering [53]. Natural polymers are often difficult to process and pathogenic risks may be involved with natural polymers retrieved from xenogeneic or allogeneic sources. Synthetic polymers exclude these drawbacks and exhibit tailorable, predictable and reproducible physical, chemical and degradation properties [54]. Depending on several parameters such as the degree of branching, hydrophilicity and molecular weight of the polymer, synthetic polymers can be processed both as hydrogels or as solid materials. Some well-known polymers used for hydrogel fabrication are poly(acrylic acid) (PAA), poly(ethylene oxide) (PEO), poly(vinyl alcohol) (PVA) and polypeptides [55]. Examples of the most popular and most widely studied biodegradable synthetic polymers in bone tissue engineering are poly(lactic acid) (PLA), poly(glycolic acid) (PGA) and their co-polymers PLGA $[53,56]$. Furthermore, other synthetic polymers have been investigated for cartilage and bone reconstruction such as poly-(ethylene glycol) (PEG) based polymers [57, 58], poly(caprolactone) (PCL) [59], polycarbonates [60], polyfumarates [61], polyanhydrides [62], and poly(ethylene oxide terephthalate)/poly(butylene terephthalate) (PEOT/PBT) [63] co-polymers or blends thereof [64, 65].

Even though many polymer materials have been synthesized and investigated, to date no single polymer can meet all the requirements set for scaffolds in cartilage and bone tissue engineering [64]. All polymers have their own characteristics, benefits and drawbacks. Composite materials often show improved characteristics compared to their individual components with a sufficient balance between strength and toughness. Taking into account the composition of native bone, in which both organic and inorganic components are found, makes composite materials a logical choice for bone tissue engineering scaffolds $[53,66]$. Combinatorial approaches in which synthetic materials are combined with biological materials offer both a high degree of tailorability in mechanical properties as well as enhanced instructive properties due 
to their biological activity $[67,68]$. These instructive properties can result in enhanced cell attachment, proliferation and differentiation [18, 48, 69-73].

Similar as for decellularized matrices and biological materials, the optical properties of scaffolds made of synthetics are dependent on their crystallinity, autofluorescent properties, absorption coefficient, processed geometry or porosity and scaffold dimensions.

\subsubsection{Scaffold fabrication methods}

In the past two decades, a library of scaffold fabrication methods for tissue engineering applications has been developed. For nearly all common scaffold-based applications, reviews on fabrication processes can be found [54, 74]. In a review from Weigel et al. several commonly used fabrication methods are outlined with examples of specific applications per method [75]. In the following section we will shortly introduce some well-known, but also some recently developed scaffold fabrication methods and their implications in imaging methods. A resulting example from each method is given in Figure 2.1.

\section{Phase-separation methods}

One of the earliest scaffold fabrication processes is based on phase-separation principles (Figure 2.1A). The methods and parameters in phase-separation processes have been reviewed recently [76]. Highly-porous scaffolds obtained by phase-separation techniques find their use in a broad range of applications from soft scaffolds to study vascularization to sponge-like constructs for cartilage regeneration and stiff scaffolds for bone tissue engineering [77-80]. The porosities obtained by this fabrication methods vary per polymer type and concentration but mostly range from approximately $60 \%$ to $97.5 \%$ [76]. The morphology of the obtained pores is often tortuous, irregular and the pores generally show a large pore size distribution up to a ten-fold within one construct. Generally, the pore sizes can range from sub-micrometer to a few hundred microns and are, besides the degree of interconnectivity, largely dependent on the applied chemicals and the process parameters [76]. One specific benefit of phase-separation methods is the possibility to create longitudinal pore shapes [81] or to introduce pore size gradients within the scaffold [82].

The transparency of the material used will be a major determinant in the applicability of optical imaging techniques. Yet, even with transparent materials, the tortuous geometry of the pores introduces many interfaces in the optical path which will inevitable result in enhanced scatter and diffraction. The high porosity, and therewith low bulk density of these constructs, is expected to complicate imaging by non-optical methods. Specifically, methods in which contrast is based on the materials nature with a spatial resolution limited to several microns will suffer from the limited thickness of the material layers that are separating the pores. 


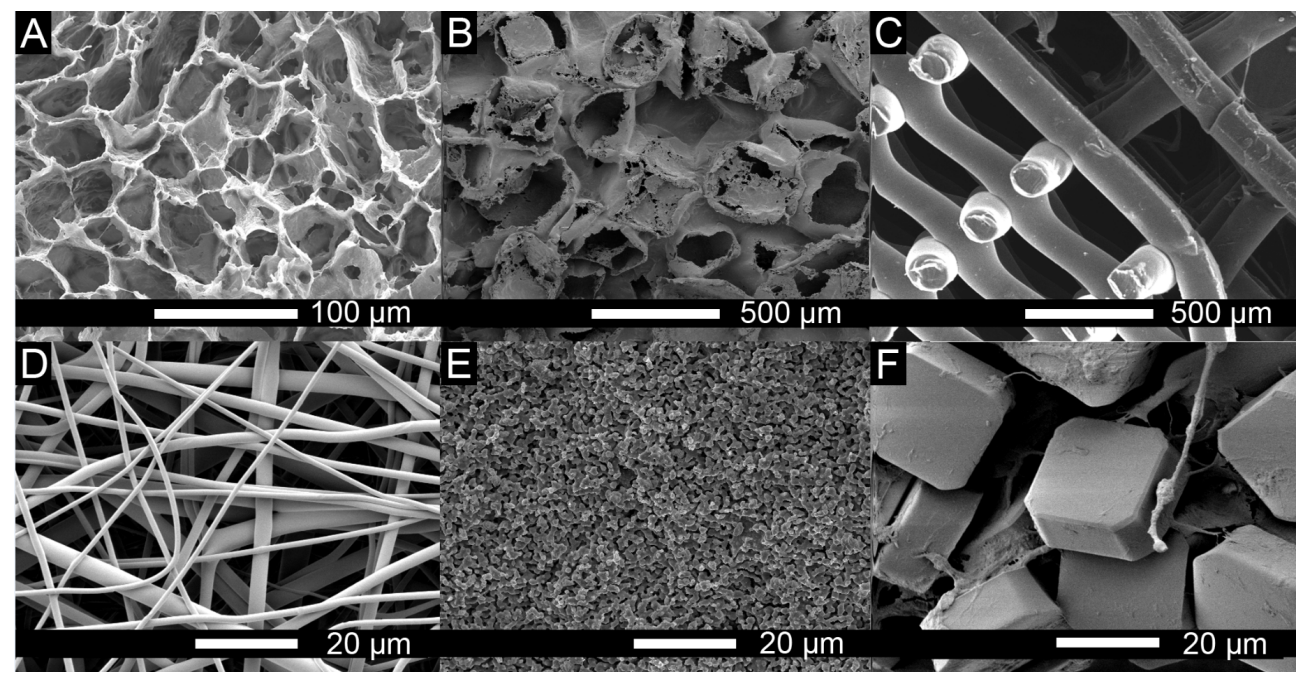

Figure 2.1: Resulting scaffold structures from various fabrication methods. (A) Thermally induced phase separation method applied on a $7 \%$ solution of PCL in 1,4-dioxane. (B) Salt-leached scaffolds of PLGA. (C) Fused deposition modeled scaffolds of PEOT-PBT. (D) Electrospun meshes of PEOT/PBT. (E) Sintered tri-calcium-phosphate disks. (F) SU-8 micro-objects assembled by hMSCs into porous aggregates.

\section{Particle-leaching}

Particle leaching methods result in 3D porous matrices in which the pore sizes are controlled by the size of the particles (typically in the order of tens to hundreds of microns), and the porosity and interconnectivity are determined by the concentration of particles per scaffold volume (Figure 2.1B) [83-86]. Particle-leached scaffolds are fabricated by casting a solution of a ceramic or polymer, for example, with solid particles $[83,87]$. After the casted solution turned solid by evaporation of the solvent or by cooling down under the melting temperature, fully solid constructs are retrieved. Subsequently, the particles are leached out by immersing the full construct in a solvent for the particles but a non-solvent for the chosen polymer. This results in scaffolds with porosities in the range of $30 \%$ to $98 \%$ [88]. The most commonly used particles are sugar or salt-based because of their good solubility in water. The types of scaffolds retrieved with this method are besides many other applications also widely applied in in musculoskeletal tissue engineering, membrane-like scaffolds for urological purposes and in in vitro vascularization research [89]. The limitations of imaging these types of scaffolds are similar to those of scaffolds fabricated by phase separation methods. This similarity is caused by the comparable nature of the scaffolds geometry, introducing many thin layers per volume in highly porous scaffolds.

\section{Rapid prototyping}

Rapid prototyping techniques allow researchers to generate scaffolds with outer geometries based on computer-aided design (CAD) [90-92]. The field of rapid prototyp- 
ing includes fused deposition modeling of thermoplastic materials [93-95], 3D printing of pastes or liquids [96], selective laser sintering (SLS) [97-100] and stereo-lithography applied to photo-sensitive materials [101-104]. Rapid prototyping techniques gained interest because of the capability to create scaffold geometries with well-defined parameters and a high reproducibility (Figure 2.1C) [74]. This results in scaffolds with porosities and pore sizes virtually ranging in the whole possible spectrum. Typically, rapid prototyped scaffolds with porosities from $30 \%$ to $95 \%$, and with pore sizes ranging from tens of microns to millimeters have been reported [74]. Another degree of freedom is enabled by the step-wise or layer-by-layer processing in rapid prototyping methods which allows combining multiple materials into one construct. Due to the often relatively large pores and the geometries introduced by these methods, many scaffolds only block the applicability of imaging methods to a certain extent, even if the materials are opaque. One can imagine that the regular structure of the construct enables observations through longitudinal pores. When transparent materials are used, the number of interfaces that optical light will have to cross is much lower than for scaffolds produced with phase-separation or particle leaching methods. However, high resolution at greater imaging depths will be still limited, mainly due to the numerical aperture of the objectives that will be utilized

\section{Electrospinning}

Electrospinning (ES) is a commonly used scaffold fabrication process to obtain nano to micro-fiber meshes with high porosities mimicking the collagenous morphology of native ECM (Figure 2.1D) [105-107]. The method is based upon charging a solution of a chosen material and subsequent extrusion through a capillary tip or needle. A jet is drawn from the needle towards a collector due to the presence of an electric field. Varying process parameters such as electric field strength, distance between needle and collector, polymer concentration, and extrusion speed allows tuning of the fiber diameter and morphology. Fabricated scaffolds are typically meshes or membranes with porosities varying from $80 \%$ to $99 \%$, but small pore sizes typically in the range of tens of nanometers till tens of micrometers [106]. Since the ES process is mostly applied to fabricate sheets or disks with limited thicknesses (the majority between 200 and 500 microns) no major additional implications are expected to play a role in the applicability of imaging methods compared to other fabrication methods.

\section{Sintering}

Sintering is mainly applied for hard-tissue engineering and is based on the heattreatment of a powder to make nano- or micro-particles partially fuse with each other [108-110]. Sintered scaffolds cover a wide range of porosities from $5 \%$ to $80 \%$ with pore sizes ranging from tens of microns to sub-millimeter [88]. Sintering is traditionally applied on ceramics, but has also shown its potential for other materials such as metals, glasses and certain polymers and composites (Figure 2.1E). Sintering can be applied locally with the use of lasers (SLS), which allows the fabrication of scaffolds with CAD designed geometries as previously described in the section on rapid prototyping technologies [97]. When sintering is applied to obtain a homogenously dense 
construct of ceramic materials, imaging possibilities will be restricted to non-optical material penetrating methods, such as micro-CT or MRI. When amorphous materials are utilized, optical methods could be applied. However, due to the multiple interfaces of material with culture medium upon in vitro culture, the achievable resolution and imaging depths are limited because of scattering and diffraction.

\section{Bottom-up approaches}

Bottom-up approaches have been recently introduced to overcome hurdles faced with mm-sized 3D scaffolds caused by limited access of the scaffold for surface or bulk modification and functionalization, as well as for nutrient availability. These hurdles include inhomogeneous cell distribution [111], necrotic cores [112], a limited remodelling capacity and a limited control of cell fate. Bottom-up designs have shown the potential to construct tissues with defined properties including spatial and temporal control at a cellular level $[113,114]$. The porosities and pore sizes are determined by the physical properties of the individual units and by the assembling properties and can in theory be ranging from approximately $10 \%$ to $80 \%$ and from nanometers to hundreds of micrometers, respectively. With the freedom in modulating the sizes and shapes of the building blocks, the most optimal porosity and pore size per application can be easily fabricated [88]. By creating micrometre-scaled building blocks from cells combined with biomaterials eventually comprising instructive capacities, complex tissues can be created and mechanisms of tissue development can be studied (Figure $2.1 \mathrm{~F})[115]$. When using monodispersed spheres, compaction will be limited introducing a high interconnectivity [116]. Bottom-up approaches based on gel-like materials allow the cells to reside in an ECM mimicking matrix retaining their rounded morphology $[114,117]$. The use of hydrogels and engineered micro-objects have shown a high potential in injectable systems to reduce the invasiveness of surgical procedures in vivo and allow for controlled assembly to achieve complex tissues in vitro. The applicability of imaging methods to monitor cell fate and tissue growth is in bottomup engineered scaffolds dependent of the optical properties of the materials used, the ratio of material versus tissue and the density of the obtained $3 \mathrm{D}$ constructs.

\section{$2.3 \quad$ Imaging modalities}

Imaging methods have gained growing interest over the past decades in the field of tissue engineering. The importance of non-invasive monitoring of cell and tissue behavior during culture, to be able to more rationally predict the success of the construct upon implantation, has been widely acknowledged [118]. Conventional destructive quality assessment procedures such as histological analysis are still the golden standard, mostly because of their high spatial resolution and specificity. Yet, for these analysis the engineered construct is sacrificed which constrains the ability to instantly and accurately adapt culture conditions. Non-destructive technologies can overcome this inefficient and costly approach. Imaging-based non-destructive technologies enable real-time determination of parameters such as the cell number and distribution, and the tissue type, content and distribution. With these insights and understanding 

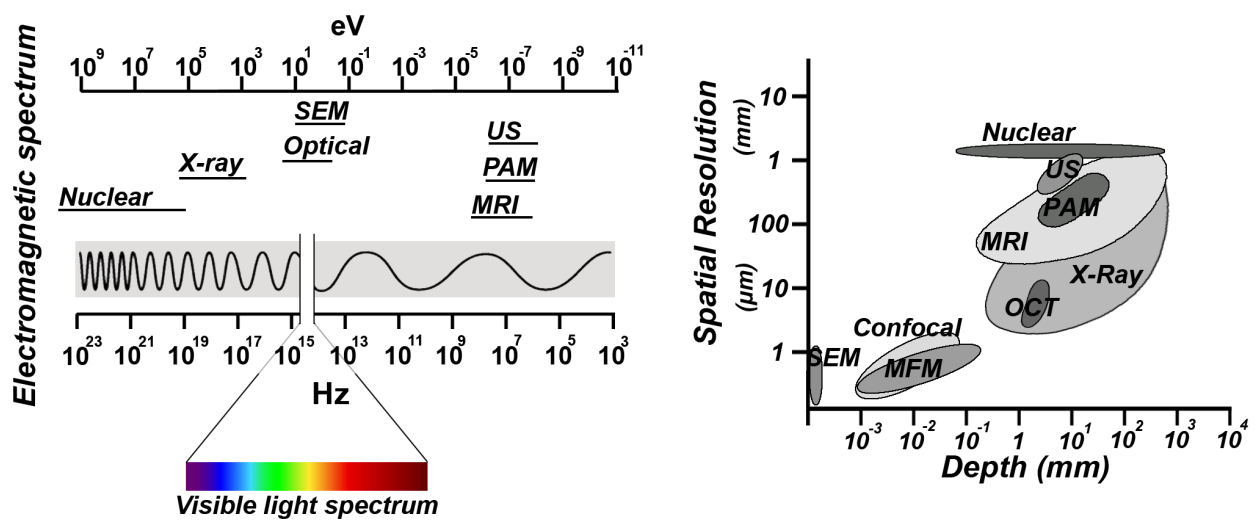

Figure 2.2: (Left) The electromagnetic properties of various imaging modalities. (Right) Spatial resolutions and imaging depths obtained by conventional imaging methods applied on tissue samples.

of culture conditions, immediate optimization of culture parameters could be carried out, which ultimately results in faster and more efficient procedures.

Generally, imaging modalities require changes in interactions of electromagnetic or mechanical energy among various substances to be able to retrieve contrast between these substances. These changes in interactions include changes in the energy due to absorption, refraction, or scattering [119, 120]. Parameters such as imaging depth, contrast, and spatial resolution achieved by a given imaging modality are largely based on the type and frequency of energy employed (Figure 2.2). Here, we will outline some commonly used and some more promising imaging modalities for assessing in vitro tissue engineering constructs.

\subsubsection{Electron-beam imaging}

The two most widely used electron-beam based imaging methods in tissue engineering are scanning electron microscopy (SEM) and transmission electron microscopy (TEM). SEM can provide high resolution images up to a few nanometers, but has limitations with respect to penetration depth [121]. In tissue engineering, SEM is mostly applied to assess scaffolds quality after fabrication prior to cell culture or implantation, and after culture or implantation. SEM is often referred to as destructive, since conventional SEM requires dehydration and fixation of biological samples $[9$, 122]. However, there are SEM devices that have an environmental (ESEM) modality such as cryo-SEM in which hydrated unfixed tissues can be studied [121, 123-125]. In a study of Doyle et al., cryo-SEM was applied to study the morphology of colonies of fibroblasts on poly-L-lactic acid (PLA) [126]. Yan et al. imaged cell growth of mouse osteoblast cells on plasma-treated poly--caprolactone (PCL) nanofibers in wet-mode SEM [127]. This method can be applied on large mm-sized constructs, but also ESEM will only reveal information from the exterior surface of the construct. Despite the benefits ESEM can offer over conventional high-vacuum SEM, it is not extensively 
applied in the field of tissue engineering, whereas it is a commonly used imaging method in food industry and plant sciences. TEM requires sample fixation and processing into thin sections and is therefore considered a destructive endpoint imaging method [128]. Therefore, TEM has in our view no potential in non-invasive monitoring of tissue growth or cell fate in $3 \mathrm{D}$ constructs.

\subsubsection{Nuclear imaging}

Nuclear based imaging techniques have shown potential in many in vivo applications such as visualization of lymphatic and vascular systems [129]. For in vitro applications, however, to date nuclear-based methods are not yet commonly applied. The lateral resolution of nuclear imaging modalities is limited, since most available devices are mainly optimized for human-scale use with a resolution of 1-2 mm [130]. To be able to achieve contrast in nuclear based imaging methods such as single-photon emission computed tomography (SPECT) and positron emission tomography (PET), radioactive agents are required. Although PET and SPECT cannot yet provide single cell resolution, which would be desirable in monitoring cell fate in tissue engineered constructs, both methods could still be valuable tools enabling cell-cluster localization and cell function in vivo and in vitro. For example by labeling cells with radioactive tracer molecules such as fluorine-18 radiolabeled-fluorodeoxyglucose $\left({ }^{18} \mathrm{~F}\right.$-FDG) or fluorine-18 radiolabeled-9-[4-fluoro-3-(hydroxymethyl)butyl]guanine ( ${ }^{18} \mathrm{~F}-\mathrm{FHBG}$ ) for PET imaging, non-invasive cell tracking is aided $[131,132]$. A drawback of ${ }^{18}$ F-FDG is the high tracer elution rate from the cells [133], which makes this tracer mainly applicable for short-time monitoring [134]. Also for SPECT a library of tracers is developed which can be targeted to specific cell surface receptors, metabolites or genes [135-137]. The addition of computed tomography (CT) to PET or SPECT imaging has shown to allow precise anatomic co-registration of functional information with anatomy in small animals [138]. Recently, micro-SPECT was developed and compared to micro-CT to image a whole-mouse skeleton. However, anatomical atlas-based segmentation and image processing was required to be able to reconstruct 3D models of the detected skeleton [139]. Furthermore, applying tools such as pinhole collimators to improve SPECT resolution have the consequence that longer scanning times are required due to reduced photon sensitivity [138]. Overall, PET and SPECT have high potential in clinics to add functional information on to anatomical structures imaged by other imaging modalities. The applicability of nuclear based imaging methods on in vitro tissue engineered constructs with a sub-mm scale resolution is to date still limited.

\subsubsection{Optical imaging}

Optical imaging is based on systems that measure the interaction of light (approximately $10 \mathrm{~nm}$ up to $400 \mathrm{~nm}$ for ultraviolet, $400 \mathrm{~nm}$ up to $710 \mathrm{~nm}$ for visible light and $710 \mathrm{~nm}$ to $1 \mathrm{~mm}$ for infrared light) with matter. These interactions can show differences in scatter, absorption or luminescence which, depending on the imaging modality, can be optically visible or can be displayed after computing retrieved spectra into images. 


\section{Epi- and transillumination microscopy}

In epi- and transillumination microscopy, visible light is projected onto a specimen and contrast or colors are dependent on absorption and reflection, scatter and breaking of the light. Epi-illumination modalities such as stereomicroscopy are applied on opaque specimens from which reflected light is captured revealing information from the surface of the specimens only. Commonly used transillumination microscopy based imaging modalities are bright field microscopy, phase contrast microscopy [140] and differential interference contrast (DIC) [141] microscopy, for which the applicability is restricted to imaging two-dimensionally (2D) and in $3 \mathrm{D}$ to thin $(300 \mu \mathrm{m})$ and virtually transparent constructs [9].

Bright field microscopy renders most detail of living cells invisible since there are no large differences in absorption by the structures inside cells. Phase-contrast microscopy is based on differences in refraction which lead to a phase-delay in some of the light causing contrast in the images. DIC imaging allows detailed microscopic examination of the matrix texture and cell orientation in the plane of the construct [141], and can be applied to study dynamics in living cells since this methods is noninvasive and continuous [142]. For several types of rapid prototyped scaffolds with longitudinal pores cultured with cells in vitro, bright field microscopy can still be applied to gain some insight in tissue growth in the early phase. However, when the formed tissue becomes denser, complete absorption of the light will inhibit further assessment with transillumination based methods.

\section{Fluorescence microscopy}

Optical fluorescent imaging has developed into an important tool in biomedical research both in vitro and in vivo. Fluorescence microscopy allows for non-invasive cell and tissue monitoring in which contrast is offered by differences in auto-fluorescent properties of tissue constructs due to endogenous fluorophores present in all tissues [143-145], endocytosis or transfection of fluorescent probes [146], or targeted fluorescent exogenous probes $[147,148]$. Depending on the fluorescence modality applied (e.g. epi-fluorescence, confocal-fluorescence, multi-photon-fluorescence) and the excitation wavelengths utilized, imaging depths between sub-micron up to whole-animal imaging in the cm-scale can be achieved [149, 150]. The majority of studies on cell fate in which fluorescence microscopy is applied in 3D are focused on in vivo cancer metastasis, cell homing and cell differentiation [151]. Martin et al. showed that combining bright field microscopy with fluorescent microscopy on ex vivo slices of unstained bone scaffolds enables the quantification of formed bone matrix by autofluorescence detection [144]. Cowles et al. applied near-infrared (NIR) optical imaging with a bone-specific NIR-targeted probe to non-invasively study mineralization of tissue-engineered bone constructs over time in vivo [152]. By the application of NIR, imaging problems related to autofluorescence from the native tissue can be eliminated [138]. In another study, NIR fluorescent imaging was applied to monitor scaffold degradation in vivo [153]. For in vitro cell studies, De Mel et al. showed that biofunctionalized quantum dots have great potential for live monitoring of endothelial progenitor cells seeded in mm-sized polymeric scaffolds and cultured in a pulsatile flow bioreactor for vascular tissue engineering applications [154]. Although, whole-body 
imaging of mice was shown to be feasible, the spatial resolution with such imaging depths drastically decreased from submicron to $\mathrm{mm}$ scale in which only clusters of cells were detectable $[149,155]$. Most conventional fluorescent microscopes found in tissue engineering laboratories, have limited penetration depths of both the excitation and emission wave-lengths when applied on dense tissues such as cartilage and bone and on opaque materials.

\section{Multiphoton microscopy (MPM) and second harmonic generation (SHG)}

Fluorescence microscopy has long been used for visualizing cells and angiogenesis in scaffolds as described earlier. However, due to strong light scattering, especially in the presence of blood, conventional fluorescence microscopy shows a poor tissue penetration of several hundred micrometers. MPM has shown to partly overcome this limitation and allows imaging two- to -three times deeper into specimens, while enabling optical sectioning into stacks for 3D reconstruction [156, 157]. For MPM, some specialized optical effects can be applied to enable label-free imaging of cells within scaffolds without the requirement of sample preparation [12]. Imaging with SHG requires high photon densities and, to avoid tissue damage, short pulses of laser light, as provided by picosecond or femtosecond multi-photon lasers [142]. Conventionally available multiphoton lasers generated light with wavelengths ranging from 700 to nearly $1,000 \mathrm{~nm}$. The emission detection for SHG will be in the range of 350-500 $\mathrm{nm}$ when these lasers are applied. In biological specimens, SHG signals are obtained from proteins that contain a high amount of higher-order structures, for example from alpha-helical structures which are present in collagens and elastic fibers [158]. Because of its high resolution and penetration depth, yet with only moderate photo-toxicity, this technique holds strong promise for future developments in live cell and matrix research exploiting non-linear molecular characteristics of molecules and tissues.

Sun et al. have applied a combinatorial modality of MPM with SHG imaging to investigate the nonlinear optical properties of five commercially available scaffold materials: a collagen composite scaffold, a bone graft matrix strip (collagraft $\AA$ ), an open-cell PLA scaffold, a PGA scaffold, and a nylon mesh [159]. They showed that MPM is effective in providing spectrally-resolved morphological information of the materials and hypothesized, yet did not show, that this method can be used to study cell-matrix interactions when cells are cultured on these scaffolds. In other studies, MPM was applied on tissue engineered constructs and was combined with SHG imaging to non-invasively retrieve insights on the interaction between scaffolds and tissues or between scaffolds and cells in vitro and in vivo [118, 160, 161]. For example in the study of Lee et al. ECM formation on PGA electrospun scaffolds was followed and showed to initially align along the scaffolds fibers, while after inducing chondrogenesis for several weeks scaffold reorganization was observed [118]. Pena et al. have also shown scaffold remodeling during culture, in this case in collagen matrices seeded with fibroblasts [161]. Furthermore, combining SHG with MPM showed that among other structural parameters the molecular orientation of the sample and the overall beta sheet content could be detected [145, 162]. Overall, combinatorial imaging modalities based on MPM and SHG provide information about materials present in tissue en- 
gineered constructs, ECM components such as collagens, and cells simultaneously in separate channels $[145,163]$. This allows for adequate (automated) image analysis of specific (labeled) components per channel. Ultimately, this enables novel approaches to directly modify culture parameters to induce or prevent certain cell and tissue fate related processes.

\section{Bioluminescence(BLI)}

BLI uses light emission produced through enzymatic catalysis of, for example, luciferin by a luciferase (LUC) enzyme. The principle has proven useful to monitor gene expression and cellular activities both in vitro and in small animal models in vivo [164-166]. Several studies have shown the correlation between luciferase activity and the number of cells within tissues in vivo or scaffolds in vitro. [167-170]. LogeartAvramoglou et al. have shown the quantification and characterization of luminescence from live-cells and cell lysates after culture on polymeric translucent soft hydrogels and on opaque hard ceramics [171]. Olivo et al. reported a further correlation between luciferase activity, the number of cells and bone formation in vivo [172]. In other studies, osteogenesis was assessed by monitoring gene-expression-dependent bioluminescence by coupling of luciferase reporters to the promoter of osteocalcin $[169$, 173-175]. Because of its high sensitivity, bioluminescence technology has recently proven its usefulness in tracking stem cells on material scaffolds transplanted in live animals for tissue engineering purposes[175]. One of the limitations of BLI is the limited resolution, which can range from tens of microns to millimeters. Furthermore, to the best of our knowledge, the current technology to image BLI does not allow for retrieving $3 \mathrm{D}$ imaging stacks of tissues and tissue constructs, thereby limiting the reconstruction modalities of $3 \mathrm{D}$ tissue development.

\section{Optical coherence tomography (OCT)}

OCT was first introduced by Huang et al. for the assessment of biological tissues [176]. OCT has been used for label-free imaging of tissue/scaffold constructs at a relatively high resolution in the sub-micron range [9]. Depending on the type of scaffold, it can be rather difficult to distinguish between the tissue and the scaffold when their refractive indices are similar $[177,178]$. A light beam from a broad bandwidth light source is focused into a sample and the time that the light takes to return from the specimen to the detector is measured. This echo time-of-flight information enables the determination of the depth in the sample from where the light was scattered $[120,176$, 179]. OCT is applied in the field of tissue engineering to characterize the architecture of scaffolds including porosity, pore distribution and interconnectivity prior to cell culture [180]. In deep tissue imaging, OCT is one of the most used optical imaging modalities for its high spatial resolution of $<15 \mu \mathrm{m}$ in scattering matter at depths up to $2 \mathrm{~mm}[181,182]$. Wang et al. applied OCT to assess scaffold-assisted wound healing in mice and compared their results to conventional hematoxylin and eosin staining [183].

Tissue development in vitro was monitored with OCT by detecting an increase in backscattered light over time [184]. In in vitro tissue engineering, OCT combined 
with Doppler velocimetry has been applied for characterization of flow in engineered tissues, such as artificial blood vessels, by increasing the obtained contrast compared to conventional OCT $[185,186]$.

In another study of Liang et al., three other combinatorial modalities have been introduced and evaluated for tissue engineering applications, namely OCT and multiphoton microscopy (OCM/MPM), optical coherence elastography (OCE) and spectroscopic OCT (SOCT) [178]. OCM/MPM enables imaging at greater depths in highly-scattering tissues by combining the spatial optical sectioning capabilities of confocal microscopy with coherence gating and rejection of multiple-scattered photons within one modality resulting in high sensitivity and high contrast [178]. This integrated system allows to obtain microstructural and functional properties of engineered tissues simultaneously and to display the data within one representation.

OCE reveals information on the biomechanical properties of tissues by applying mechanical stimulation to the material with simultaneous OCT detection. Dependent on the optical properties of the tissues, the main features of OCE can include millimeters penetration depth and spatial resolution in the micron scale. SOCT is based on spectral analysis and intensity analysis of backscattered light from tissues. Similar to OCM, OCE and conventional OCT, SOCT can obtain spatial resolutions in the micron scale [187]. In conventional OCT, no exogenous fluorophores are required since OCT relies on variations in indices of refraction and optical scattering for image contrast [182]. Therefore, OCT can be considered a non-invasive label-free imaging modality enabling cellular imaging within living specimens over time without loss of viability [188].

\section{Raman microspectroscopy}

Raman microspectroscopy is a label-free spectroscopic technique, which does not require special sample preparation and can be used for non-invasive characterization of cell and tissue biochemistry [189, 190]. Careful selection of suitable laser wavelengths and laser intensity can eliminate cell damage allowing for the study of cells without inadvertently changing their phenotype or behavior caused by photo damage [191193]. Raman spectral studies have been performed for structural analysis of ECM components such as collagen [194] and proteoglycans [189, 195]. Raman peaks at distinct wavelengths exist, for example, for different types of carbon-carbon bonds, amide, carboxyl, sulfhydryl, and phenol groups [120]. In some relatively complex samples, Raman peaks could be characterized by entire molecules, such as carotenoids, glucose, and hydroxyapatite (HA) [120]. Spectral information retrieved by scanning specimens over a certain area, optionally confocal, can be computed and displayed as (3D) cluster images [196]. Raman spectroscopy and Raman spectroscopy based imaging has been successfully applied in several tissue engineering applications for example by monitoring chondrocyte behavior on bioactive scaffolds [197]. Boyd et al. have utilized a bench-top macro-Raman spectrometer with high-throughput screening capability to examine spectral differences between well characterized cell lines (two types of osteosarcoma cells, human dermal fibroblasts and human embryonic lung epithelial cells) and the effects of cellular death on the retrieved spectra [198]. 


\subsubsection{Ultrasound(US)}

US based imaging is, in principal, similar to OCT except that acoustic waves are used instead of near-infrared light [179]. Compared to OCT, clinical US has a lower resolution but higher penetration depth. Although US imaging is widely applied in the clinics, not much research has been reported on applying US methods on in vitro cultured scaffolds. US-based monitoring methods have, similarly to X-ray based micro-CT, OCT and MRI, already been applied to non-destructively assess scaffolds properties during and after fabrication [199, 200]. Mather et al. applied ultrasonic pulse-echo reflectometry to monitor changes in acoustic impedance of poly(D,L-lactic acid) (PLDLA) based scaffolds during supercritical scaffold fabrication [199]. Kim et al. introduced ultrasound elasticity imaging (UEI) on tissue engineered constructs to monitor scaffolds degradation in vitro and in vivo with an axial and lateral resolution of approximately $250 \mu \mathrm{m}$ and $500 \mu \mathrm{m}$, respectively [200]. Yet, both these method did not provide sufficient spatio-temporal information on the scaffolds structure, to be able to draw conclusions on tissue development throughout a 3D construct.

Rice et al. opted to use US to monitor cartilaginous matrix development in chondrocyte seeded poly(ethylene glycol) (PEG) hydrogels in vitro [201]. Kreitz et al. have also evaluated the potential of US for quantitative in vitro monitoring of tissue development in a hydrogel-based 3D tissue engineered construct. They showed a correlation between the grey-scale values of the obtained images to hydroxyproline content, which is a marker of collagen formation [202]. In a study of Fite et al., US backscatter microscopy (UBM) was combined with time-resolved fluorescence to follow the progression of tissue maturation along the chondrogenic lineage by monitoring collagen type- 2 production and by detecting changes in mechanical properties of poly(lactic-co-glycolic acid) (PLGA) based constructs upon in vitro culture [203]. UBM can provide structural information, respectively with an axial and lateral resolution of approximately $30 \mu \mathrm{m}$ and $65 \mu \mathrm{m}$, that can be correlated to tissue microstructure and constructs stiffness, which can be a measure for the functionality of cartilage and bone-like tissues constructs [203]. Overall, the applicability of US based imaging methods to monitor tissue growth in mm-sized tissue engineered constructs highly depends on the aimed resolution and imaging depth, the targeted tissue type, and the sound transmission properties of these tissues and scaffold materials.

\subsubsection{Photoacoustic tomography (PAT) and photoacoustic microscopy (PAM)}

PAT is a relatively novel but fast developing clinically applied non-invasive and nonionizing method to monitor tissues in vivo and to detect for example blood oxygenation in situ [204-207]. The method is based on the collection of ultrasonic waves resulting from heat expansion of tissues after absorption of laser irradiation within those tissues [208]. Large imaging depths up to $\sim 7 \mathrm{~cm}$ can be achieved since the light only has to travel in one direction and will result in a sound wave upon light absorption [209]. In PAT and PAM, the spatial resolution correlates with the imaging depth and depends on the application, yet a high depth-to-resolution ratio is maintained [210]. Recently, a lateral resolution of $5 \mu \mathrm{m}$ with an imaging depth of $1 \mathrm{~mm}$ 
was obtained in highly scattering soft tissue [211]. By modulating the US detection frequency after laser irradiation, PAT enables high-resolution imaging of biological structures with strong optical absorption contrasts [212]. Although PAT and PAM are promising imaging methods for in vivo applications, to date just a few researchers have investigated the potential of these methods for the field of tissue engineering [130]. Recently, PAM has been applied to retrieve structural information on tissue engineering constructs in vitro $[213,214]$ and in vivo $[122,211]$. Cai et al. incorporated carbon nanotubes in PLGA scaffolds to be able to obtain detectable contrast between the polymeric scaffold and surrounding tissue [213]. Other approaches have introduced NIR fluorescent proteins in vivo to enable multi-contrast next to already present endogenous contrast agents such as hemoglobin [208]. Such contrast agents could also be applied to cells in vitro in tissue engineered constructs. To be able to extract more information from tissue engineered constructs, multi-modal imaging techniques can be applied. PAM could for example be combined with US-based imaging as was already done in vivo [215].

PAM has some limitations when imaging bony or air-filled tissues, caused by limited transparency and the absence of a US wave transporting medium [211]. Despite these two major limitations, we still consider PAT and PAM to be promising in analyzing biomaterial-tissue interactions in soft tissue engineering applications in a completely non-invasive and non-ionizing manner.

\subsubsection{X-ray based micro-computed tomography (Micro-CT)}

Previously, X-rays were clinically applied as fast diagnostic tool to obtain direct 3D whole-body projections on 2D photo-sensitive films. Currently, X-ray imaging combined with computed tomography (CT) can be applied in scanning mode at distinct focal planes and with varying projection directions enabling $3 \mathrm{D}$ reconstruction of the information [119, 216]. Depending on the spot size of the generated X-ray, the beam properties and mostly the detector properties, nanometer scale resolution has been achieved [217].

One of these CT modalities is micro-CT which enables tissue engineers and material scientists to evaluate the morphological structures of their dry materials and fabricated scaffolds non-destructively with high resolution and accuracy [218-220]. However, when polymeric scaffolds are immersed in physiological fluids in vitro, or embedded in vivo, wherein fluids perfuse through the scaffolds, the contrast of microCT images has shown to be poor [213].

Similar to magnetic resonance imaging (MRI), also micro-CT is capable of distinguishing soft tissue material from harder mineralized tissues [213, 221]. However, instead of contrast resulting from changes in proton dynamics, X-ray contrast is the result from differences in absorption, refraction and/or scattering properties of the materials. Bone, fibrous tissue and ceramic scaffolds present different coefficients of X-ray absorption, therefore their 3D structures can be separated and corresponding quantitative data such as bone volume, thickness, growth, destruction, remodeling and changes in bone density can be obtained [220, 222]. However, contrast between distinct types of soft tissue with similar X-ray attenuation is limited [223]. 
One approach to improve contrast between various soft tissues is by the application of contrast agents [11]. Tissue engineering studies that do not assess mineralization often require those toxic contrast agents or sample processing prior to imaging. Unfortunately, most stained scaffolds are no longer usable for culture due to high toxicity of the applied contrast agents. Another approach to improve contrast is by combining micro-CT with for example X-ray phase contrast. When these contrast related challenges can be overcome, monitoring of soft tissues and live-cells during scaffold culture can be a major future application [6, 224, 225]. Zhu et al. have shown the application of X-ray diffraction enhanced imaging (DEI) on the characterization of rapid prototyped scaffold geometry, chitosan scaffold structure and on muscle tissue morphology [225]. With the latter they showed the feasibility of further developments to better image low-contrast soft tissues.

\subsubsection{Magnetic resonance imaging (MRI)}

Applications of MRI are often described when methods for 3D non-invasive imaging of non-transparent biological materials in the mm-scale with relatively high resolution are reviewed $[4,119,226]$. MRI can be applied either label-free or with targeted magnetic beads for example to be able to track or localize specific components or cells [227-229]. Contrast in MRI images is based on proton densities and differences in the spin-phase and relaxation time of these protons, among others due to variations in tissue hydration or water/lipid ratios [230].

MRI has shown to be a promising imaging modality for the assessment of musculoskeletal tissue engineered constructs [7, 231-235]. In a study of Washburn et al. for instance, an inverse relationship between MR relaxation times and mineral concentration was found after culturing osteoblasts on poly-(ethyl methacrylate) (PEMA) scaffolds [236]. Chesnick et al. showed similar collagen mineralization results in cartilage tissue engineering [237]. Other studies have shown a correlation between collagen orientation and $\mathrm{T} 2$ relaxation times in articular cartilage [238, 239] and in tendons [240].

Recently, advances have been made in the realization of MRI-compatible bioreactors to be able to assess cell fate and tissue growth longitudinally [241, 242]. Implementation of contrast agents in MRI enables cell tracking both in vitro and in vivo [229, 243-246]. Immobilization of contrast agents on nanoparticles is required for cell labeling via endocytosis [247, 248]. Upon endocytosis, accumulation of the agent leads to a darker or brighter signal, which will either reduce or increase the contrast between the labeled cells and the scaffolds depending on the type of contrast agent used [249]. Although MRI seems to be very promising in non-invasive tissue construct quality assessment, this technology has not yet become part of standard laboratory equipment [250]. To increase the signal-to-noise ratio in a voxel, and consequently increase the spatial resolution, the use of high-field MRI and long scanning times are required. Devices capable of applying sufficient magnetic field strengths for micro-MRI are expensive and not yet developed to fit in standard tissue engineering laboratories [251, 252]. 


\subsection{Discussion and future outlook}

The need for novel approaches to monitor the cell and tissue related parameters that play a major role in the success and quality of tissue engineered constructs is well acknowledged. This monitoring is not only pivotal for the assessment of the engineered construct prior to implantation, but can also aid in the optimization of the culture conditions. By gaining real-time insights in cell and tissue fate, direct interventions could be foreseen, which would increase the efficiency and decrease the costs of the chosen tissue engineering approach. These insights are expected to be of even greater value when spatio-temporal information is revealed.

In the past few decades, many scientists have put effort in developing and optimizing non-invasive methods to assess tissue growth, cell fate and scaffolds integrity in vivo and in vitro. Despite all these advances reviewed here, the mostly applied method for the evaluation of the performance of a tissue engineered construct still remains destructive histological analysis. One of the main reasons for this being the golden standard is the wide applicability on different types of tissues, materials and cells. Moreover, histological analysis allows for multi-colored labeling of tissue sections providing functional information with high accuracy, specificity and resolution. Yet, some imaging modalities have already showed to perform similar or even better in the characterization of cell functionality in specific samples. Depending on the application, location and size of the tissue engineered construct a specific imaging modality could be chosen and optimized to obtain the desired information without the need to disrupt the sample.

Recent developments in multi-modal imaging will help to overcome specific method-based limitations by combining the benefits of each individual imaging method. Furthermore, incorporation of sensor based information can further move forward the comprehensiveness of retrieved information from a single sample during culture. One can think of cell localization and oxygen concentration by multi-modal imaging within a 3D construct cultured in a bioreactor [253] and subsequent cell functionality determination by detecting protein secretion with protein-specific circuitry integrated sensors [254, 255]. Wireless nanoscale biosensors have been developed, which in theory could be incorporated within a scaffolds revealing information with a certain spatio-temporal resolution $[256,257]$. Ultimately these sensors could be combined with actuators resulting in a responsive autonomous system capable of locally providing instructive signals. Parameters that are currently already monitored by sensor-actuator based systems are $\mathrm{pH}$, oxygen saturation and temperature. However, observing recent advances in sensor-actuator technology, we think that protein secretion, surface marker expression or even gene expression will be included in the next generation of targeted parameters.

The combination of this information could allow a tissue engineer to adapt the culture conditions while following the outcomes in real-time. Ultimately, monitoring in order to automate production successfully would require integrated control systems with built-in data-analysis and programmed parameter adaptations. 


\section{Acknowledgement}

The authors gratefully acknowledge the funding from the Netherlands Institute for Regenerative Medicine (NIRM) through the grant number FES0908. 


\section{References}

[1] Doroski DM, Brink KS, Temenoff JS. Techniques for biological characterization of tissueengineered tendon and ligament. Biomaterials. 2007;28:187-202.

[2] Santoro R, Krause C, Martin I, Wendt D. On-line monitoring of oxygen as a non-destructive method to quantify cells in engineered 3D tissue constructs. Journal of tissue engineering and regenerative medicine. 2011;6:696-701.

[3] Materna T, Rolf HJ, Napp J, Schulz J, Gelinsky M, Schliephake H. In vitro characterization of three-dimensional scaffolds seeded with human bone marrow stromal cells for tissue engineered growth of bone: mission impossible? A methodological approach. Clinical oral implants research. 2008;19:379-86.

[4] Mather ML, Morgan SP, Crowe JA. Meeting the needs of monitoring in tissue engineering. Regenerative medicine. 2007;2:145-60.

[5] Holmes C, Tabrizian M, Bagnaninchi PO. Motility imaging via optical coherence phase microscopy enables label-free monitoring of tissue growth and viability in $3 \mathrm{D}$ tissue-engineering scaffolds. Journal of tissue engineering and regenerative medicine. 2013;DOI:10.1002/term.168.

[6] Olubamiji AD, Izadifar Z, Chen D. Synchrotron imaging techniques for bone and cartilage tissue engineering: potentials, current trends, and future directions. Tissue Eng Part B Rev. 2014;PMID:24517187.

[7] Kotecha M, Klatt D, Magin RL. Monitoring cartilage tissue engineering using magnetic resonance spectroscopy, imaging, and elastography. Tissue Eng Part B Rev. 2013;19:470-84.

[8] Matcher SJ. Practical aspects of OCT imaging in tissue engineering. Methods Mol Biol. 2011;695:261-80.

[9] Smith LE, Smallwood R, Macneil S. A comparison of imaging methodologies for 3D tissue engineering. Microscopy research and technique. 2010;73:1123-33. [10] Ballyns JJ, Bonassar LJ. Image-guided tissue engineering. J Cell Mol Med. 2009;13:1428-36.

[11] Belicchi M, Cancedda R, Cedola A, Fiori F, Gavina M, Giuliani A, et al. Some applications of nanotechnologies in stem cells research. Mater Sci Eng B-Adv. 2009;165:139-47.

[12] Vielreicher M, Schurmann S, Detsch R, Schmidt MA, Buttgereit A, Boccaccini A, et al. Taking a deep look: modern microscopy technologies to optimize the design and functionality of biocompatible scaffolds for tissue engineering in regenerative medicine. $\mathrm{J} R$ Soc Interface. 2013;10:20130263.

[13] Muller WE, Schroder HC, Shen Z, Feng Q, Wang X. Inorganic polymers: morphogenic inorganic biopolymers for rapid prototyping chain. Progress in molecular and subcellular biology. 2013;54:235-59.

[14] Habibovic P, Sees TM, van den Doel MA, van Blitterswijk CA, de Groot K. Osteoinduction by biomaterials-physicochemical and structural influences. Journal of biomedical materials research. 2006;77:747-62.

[15] Habibovic P, Yuan H, van den Doel M, Sees TM, van Blitterswijk CA, de Groot K. Relevance of osteoinductive biomaterials in critical-sized orthotopic defect. Journal of orthopaedic research : official publication of the Orthopaedic Research Society. 2006;24:867-76.

[16] Yuan H, Yang Z, Li Y, Zhang X, De Bruijn JD, De Groot K. Osteoinduction by calcium phosphate biomaterials. Journal of materials science Materials in medicine. 1998;9:723-6. 
[17] Dorozhkin SV. Biphasic, triphasic and multiphasic calcium orthophosphates. Acta biomaterialia. 2012;8:963-77.

[18] Li J, Baker BA, Mou X, Ren N, Qiu J, Boughton RI, et al. Biopolymer/Calcium Phosphate Scaffolds for Bone Tissue Engineering. Advanced healthcare materials. 2013;3:469-84.

[19] Santana BP, Nedel F, Piva E, de Carvalho RV, Demarco FF, Carreno NL. Preparation, modification, and characterization of alginate hydrogel with nano-/microfibers: a new perspective for tissue engineering. BioMed research international. 2013;2013:307602.

[20] Mo XT, Guo SC, Xie HQ, Deng L, Zhi W, Xiang Z, et al. Variations in the ratios of co-cultured mesenchymal stem cells and chondrocytes regulate the expression of cartilaginous and osseous phenotype in alginate constructs. Bone. 2009;45:42-51.

[21] Chung C, Burdick JA. Influence of Three-Dimensional Hyaluronic Acid Microenvironments on Mesenchymal Stem Cell Chondrogenesis. Tissue Eng Pt A. 2009;15:243-54.

[22] Di Martino A, Sittinger M, Risbud MV. Chitosan: a versatile biopolymer for orthopaedic tissue-engineering. Biomaterials. 2005;26:5983-90.

[23] Camci-Unal G, Cuttica D, Annabi N, Demarchi D, Khademhosseini A. Synthesis and characterization of hybrid hyaluronic acid-gelatin hydrogels. Biomacromolecules. 2013;14:1085-92.

[24] Ferreira AM, Gentile P, Chiono V, Ciardelli G. Collagen for bone tissue regeneration. Acta biomaterialia. 2012;8:3191-200.

[25] McCullen SD, Miller PR, Gittard SD, Gorga RE, Pourdeyhimi B, Narayan RJ, et al. In situ collagen polymerization of layered cell-seeded electrospun scaffolds for bone tissue engineering applications. Tissue Eng Part C Methods. 2010;16:1095-105.

[26] Costa-Pinto AR, Reis RL, Neves NM. Scaffolds based bone tissue engineering: the role of chitosan. Tissue Eng Part B Rev. 2011;17:331-47.

[27] Garcia-Fuentes M, Meinel AJ, Hilbe M, Meinel L, Merkle HP. Silk fibroin/hyaluronan scaffolds for human mesenchymal stem cell culture in tissue engineering. Biomaterials. 2009;30:5068-76.

[28] Correia C, Bhumiratana S, Yan LP, Oliveira AL, Gimble JM, Rockwood D, et al. Development of silk-based scaffolds for tissue engineering of bone from human adipose-derived stem cells. Acta biomaterialia. 2012;8:2483-92.

[29] Tamasan M, Ozyegin LS, Oktar FN, Simon V. Characterization of calcium phosphate powders originating from Phyllacanthus imperialis and Trochidae Infundibulum concavus marine shells. Materials science and engineering C, Materials for biological applications. 2013;33:2569-77.

[30] Peretz H, Blinder P, Segal L, Baranes D, Vago R. Aragonite crystalline matrix as an instructive microenvironment for neural development. Journal of tissue engineering and regenerative medicine. 2008;2:463-71.

[31] Puvaneswary S, Balaji Raghavendran HR, Ibrahim NS, Murali MR, Merican AM, Kamarul T. A comparative study on morphochemical properties and osteogenic cell differentiation within bone graft and coral graft culture systems. International journal of medical sciences. 2013;10:1608-14.

[32] Viateau V, Manassero M, Sensebe L, Langonne A, Marchat D, Logeart-Avramoglou D, et al. Comparative study of the osteogenic ability of four different ceramic constructs in an ectopic large animal model. Journal of tissue engineering and regenerative medicine. 2013;DOI:10.1002/term.1782.

[33] Nakayama KH, Batchelder CA, Lee CI, Tarantal AF. Decellularized rhesus monkey kidney as a three-dimensional scaffold for renal tissue engineering. Tissue engineering. 2010;16:2207-16. 
[34] Faulk DM, Johnson SA, Zhang L, Badylak SF. Role of the Extracellular Matrix in Whole Organ Engineering. J Cell Physiol. 2013;8:984-9.

[35] Ma R, Li M, Luo J, Yu H, Sun Y, Cheng S, et al. Structural integrity, ECM components and immunogenicity of decellularized laryngeal scaffold with preserved cartilage. Biomaterials. 2013;34:1790-8.

[36] Benders KE, van Weeren PR, Badylak SF, Saris DB, Dhert WJ, Malda J. Extracellular matrix scaffolds for cartilage and bone regeneration. Trends Biotechnol. 2013;31:169-76.

[37] Badylak SF, Freytes DO, Gilbert TW. Extracellular matrix as a biological scaffold material: Structure and function. Acta biomaterialia. 2009;5:1-13.

[38] Partington L, Mordan NJ, Mason C, Knowles JC, Kim HW, Lowdell MW, et al. Biochemical changes caused by decellularization may compromise mechanical integrity of tracheal scaffolds. Acta biomaterialia. 2013;9:5251-61.

[39] Sawkins MJ, Bowen W, Dhadda P, Markides H, Sidney LE, Taylor AJ, et al. Hydrogels derived from demineralized and decellularized bone extracellular matrix. Acta biomaterialia. 2013;9:7865-73.

[40] Wolf MT, Daly KA, Brennan-Pierce EP, Johnson SA, Carruthers CA, D'Amore A, et al. A hydrogel derived from decellularized dermal extracellular matrix. Biomaterials. 2012;33:7028-38.

[41] Seif-Naraghi SB, Horn D, Schup-Magoffin PJ, Christman KL. Injectable extracellular matrix derived hydrogel provides a platform for enhanced retention and delivery of a heparin-binding growth factor. Acta biomaterialia. 2012;8:3695-703.

[42] Farnebo SJ, Woon CY, Schmitt T, Joubert LM, Kim M, Pham H, et al. Design and Characterization of an Injectable Tendon Hydrogel: A Scaffold for Guided Tissue Regeneration in the Musculoskeletal System. Tissue engineering. 2013;20:1550-61.

[43] Iafiscol M, Quirici N, Foltran I, Rimondini L. Electrospun collagen mimicking the reconstituted extracellular matrix improves osteoblastic differentiation onto titanium surfaces. Journal of nanoscience and nanotechnology. 2013;13:4720-6.

[44] Lyu S, Huang C, Yang H, Zhang X. Electrospun fibers as a scaffolding platform for bone tissue repair. Journal of orthopaedic research : official publication of the Orthopaedic Research Society. 2013;31:1382-9.

[45] Hasan A, Memic A, Annabi N, Hossain M, Paul A, Dokmeci MR, et al. Electrospun scaffolds for tissue engineering of vascular grafts. Acta biomaterialia. 2014;10:11-25.

[46] Tour G, Wendel M, Tcacencu I. Cell-derived matrix enhances osteogenic properties of hydroxyapatite. Tissue engineering. 2011;17:127-37.

[47] Thibault RA, Scott Baggett L, Mikos AG, Kasper FK. Osteogenic differentiation of mesenchymal stem cells on pregenerated extracellular matrix scaffolds in the absence of osteogenic cell culture supplements. Tissue engineering. 2010;16:431-40.

[48] Sadr N, Pippenger BE, Scherberich A, Wendt D, Mantero S, Martin I, et al. Enhancing the biological performance of synthetic polymeric materials by decoration with engineered, decellularized extracellular matrix. Biomaterials. 2012;33:5085-93.

[49] Cheng CW, Solorio LD, Alsberg E. Decellularized tissue and cell-derived extracellular matrices as scaffolds for orthopaedic tissue engineering. Biotechnology advances. 2014;32:462-84.

[50] Crapo PM, Gilbert TW, Badylak SF. An overview of tissue and whole organ decellularization 
processes. Biomaterials. 2011;32:3233-43.

[51] Arenas-Herrera JE, Ko IK, Atala A, Yoo JJ. Decellularization for whole organ bioengineering. Biomedical materials. 2013;8:014106.

[52] Song JJ, Ott HC. Organ engineering based on decellularized matrix scaffolds. Trends Mol Med. 2011;17:424-32.

[53] Liu X, Ma PX. Polymeric scaffolds for bone tissue engineering. Ann Biomed Eng. 2004;32:47786.

[54] Puppi D, Chiellini F, Piras AM, Chiellini E. Polymeric materials for bone and cartilage repair. Prog Polym Sci. 2010;35:403-40.

[55] Lee KY, Mooney DJ. Hydrogels for tissue engineering. Chemical reviews. 2001;101:1869-79.

[56] Griffith LG, Naughton G. Tissue engineering-current challenges and expanding opportunities. Science. 2002;295:1009-14.

[57] Chatterjee K, Lin-Gibson S, Wallace WE, Parekh SH, Lee YJ, Cicerone MT, et al. The effect of 3D hydrogel scaffold modulus on osteoblast differentiation and mineralization revealed by combinatorial screening. Biomaterials. 2010;31:5051-62.

[58] Buxton AN, Zhu J, Marchant R, West JL, Yoo JU, Johnstone B. Design and characterization of poly(ethylene glycol) photopolymerizable semi-interpenetrating networks for chondrogenesis of human mesenchymal stem cells. Tissue Eng. 2007;13:2549-60.

[59] Porter JR, Henson A, Popat KC. Biodegradable poly(epsilon-caprolactone) nanowires for bone tissue engineering applications. Biomaterials. 2009;30:780-8.

[60] Schuller-Ravoo S, Teixeira SM, Feijen J, Grijpma DW, Poot AA. Flexible and elastic scaffolds for cartilage tissue engineering prepared by stereolithography using poly(trimethylene carbonate)-based resins. Macromolecular bioscience. 2013;13:1711-9.

[61] Peter SJ, Miller MJ, Yasko AW, Yaszemski MJ, Mikos AG. Polymer concepts in tissue engineering. J Biomed Mater Res. 1998;43:422-7.

[62] Anseth KS, Shastri VR, Langer R. Photopolymerizable degradable polyanhydrides with osteocompatibility. Nature Biotechnology. 1999;17:156-9.

[63] Jansen EJ, Pieper J, Gijbels MJ, Guldemond NA, Riesle J, Van Rhijn LW, et al. PEOT/PBT based scaffolds with low mechanical properties improve cartilage repair tissue formation in osteochondral defects. Journal of biomedical materials research. 2009;89:444-52.

[64] Bose S, Roy M, Bandyopadhyay A. Recent advances in bone tissue engineering scaffolds. Trends Biotechnol. 2012;30:546-54.

[65] Mitchell A, Kim B, Cottrell J, Snyder S, Witek L, Ricci J, et al. Development of a guided bone regeneration device using salicylic acid-poly(anhydride-ester) polymers and osteoconductive scaffolds. Journal of Biomedical Materials Research Part A. 2014;102:655-64.

[66] Meyers MA, Chen PY, Lin AYM, Seki Y. Biological materials: Structure and mechanical properties. Prog Mater Sci. 2008;53:1-206.

[67] Scott TG, Blackburn G, Ashley M, Bayer IS, Ghosh A, Biris AS, et al. Advances in bionanomaterials for bone tissue engineering. Journal of nanoscience and nanotechnology. 2013;13:1-22.

[68] Nandakumar A, Barradas A, de Boer J, Moroni L, van Blitterswijk C, Habibovic P. Combining technologies to create bioactive hybrid scaffolds for bone tissue engineering. Biomatter. 2013;3(2). 
[69] Yang Z, Wu Y, Li C, Zhang T, Zou Y, Hui JH, et al. Improved mesenchymal stem cells attachment and in vitro cartilage tissue formation on chitosan-modified poly(L-lactide-co-epsiloncaprolactone) scaffold. Tissue engineering. 2012;18:242-51.

[70] Jin R, Teixeira LSM, Krouwels A, Dijkstra PJ, van Blitterswijk CA, Karperien M, et al. Synthesis and characterization of hyaluronic acid-poly(ethylene glycol) hydrogels via Michael addition: An injectable biomaterial for cartilage repair. Acta biomaterialia. 2010;6:1968-77.

[71] Liu SQ, Tian QA, Wang L, Hedrick JL, Hui JHP, Yang YY, et al. Injectable Biodegradable Poly(ethylene glycol)/RGD Peptide Hybrid Hydrogels for in vitro Chondrogenesis of Human Mesenchymal Stem Cells. Macromolecular Rapid Communications. 2010;31:1148-54.

[72] Marelli B, Ghezzi CE, Barralet JE, Boccaccini AR, Nazhat SN. Three-dimensional mineralization of dense nanofibrillar collagen-bioglass hybrid scaffolds. Biomacromolecules. 2010;11:1470-9.

[73] Moroni L, Hamann D, Paoluzzi L, Pieper J, de Wijn JR, van Blitterswijk CA. Regenerating Articular Tissue by Converging Technologies. Plos One. 2008;3.

[74] Yeong WY, Chua CK, Leong KF, Chandrasekaran M. Rapid prototyping in tissue engineering: challenges and potential. Trends Biotechnol. 2004;22:643-52.

[75] Weigel T, Schinkel G, Lendlein A. Design and preparation of polymeric scaffolds for tissue engineering. Expert review of medical devices. 2006;3:835-51.

[76] Akbarzadeh R, Yousefi AM. Effects of processing parameters in thermally induced phase separation technique on porous architecture of scaffolds for bone tissue engineering. Journal of biomedical materials research Part B, Applied biomaterials. 2014;DOI:10.1002/jbm.b.33101.

[77] Cao Y, Mitchell G, Messina A, Price L, Thompson E, Penington A, et al. The influence of architecture on degradation and tissue ingrowth into three-dimensional poly(lactic-co-glycolic acid) scaffolds in vitro and in vivo. Biomaterials. 2006;27:2854-64.

[78] Heijkants RG, van Calck RV, De Groot JH, Pennings AJ, Schouten AJ, van Tienen TG, et al. Design, synthesis and properties of a degradable polyurethane scaffold for meniscus regeneration. Journal of materials science Materials in medicine. 2004;15:423-7.

[79] Zhao F, Yin Y, Lu WW, Leong JC, Zhang W, Zhang J, et al. Preparation and histological evaluation of biomimetic three-dimensional hydroxyapatite/chitosan-gelatin network composite scaffolds. Biomaterials. 2002;23:3227-34.

[80] Jensen J, Rolfing JH, Svend Le DQ, Kristiansen AA, Nygaard JV, Hokland LB, et al. Surface-modified functionalized polycaprolactone scaffolds for bone repair: In vitro and in vivo experiments. Journal of biomedical materials research. 2013;DOI:10.1002/jbm.a.34970.

[81] Stokols S, Tuszynski MH. Freeze-dried agarose scaffolds with uniaxial channels stimulate and guide linear axonal growth following spinal cord injury. Biomaterials. 2006;27:443-51.

[82] Harley BA, Hastings AZ, Yannas IV, Sannino A. Fabricating tubular scaffolds with a radial pore size gradient by a spinning technique. Biomaterials. 2006;27:866-74.

[83] Claase MB, Grijpma DW, Mendes SC, de Bruijn JD, Feijen J. Porous PEOT/PBT scaffolds for bone tissue engineering: Preparation, characterization, and in vitro bone marrow cell culturing. Journal of Biomedical Materials Research Part A. 2003;64A:291-300.

[84] Vaquette C, Frochot C, Rahouadj R, Wang X. An innovative method to obtain porous PLLA scaffolds with highly spherical and interconnected pores. Journal of biomedical materials research Part B, Applied biomaterials. 2008;86:9-17. 
[85] Suh SW, Shin JY, Kim J, Kim J, Beak CH, Kim DI, et al. Effect of different particles on cell proliferation in polymer scaffolds using a solvent-casting and particulate leaching technique. ASAIO journal. 2002;48:460-4.

[86] Liao CJ, Chen CF, Chen JH, Chiang SF, Lin YJ, Chang KY. Fabrication of porous biodegradable polymer scaffolds using a solvent merging/particulate leaching method. J Biomed Mater Res. 2002;59:676-81.

[87] Wei G, Ma PX. Macroporous and nanofibrous polymer scaffolds and polymer/bone-like apatite composite scaffolds generated by sugar spheres. Journal of biomedical materials research. 2006;78:306-15.

[88] Karageorgiou V, Kaplan D. Porosity of 3D biomaterial scaffolds and osteogenesis. Biomaterials. 2005;26:5474-91.

[89] Janeczek Portalska K, Leferink A, Groen N, Fernandes H, Moroni L, van Blitterswijk C, et al. Endothelial differentiation of mesenchymal stromal cells. Plos One. 2012;7:e46842.

[90] Lantada AD, Morgado PL. Rapid Prototyping for Biomedical Engineering: Current Capabilities and Challenges. Annu Rev Biomed Eng. 2012;14:73-96. [91] Hollister SJ. Porous scaffold design for tissue engineering. Nature Materials. 2005;4:518-24.

[92] Mota C, Puppi D, Chiellini F, Chiellini E. Additive manufacturing techniques for the production of tissue engineering constructs. Journal of tissue engineering and regenerative medicine. 2012;DOI:10.1002/term.1635.

[93] Moroni L, de Wijn JR, van Blitterswijk CA. Three-dimensional fiber-deposited PEOT/PBT copolymer scaffolds for tissue engineering: influence of porosity, molecular network mesh size, and swelling in aqueous media on dynamic mechanical properties. Journal of biomedical materials research. 2005; 75:957-65.

[94] Kim J, McBride S, Tellis B, Alvarez-Urena P, Song YH, Dean DD, et al. Rapid-prototyped PLGA/beta-TCP/hydroxyapatite nanocomposite scaffolds in a rabbit femoral defect model. Biofabrication. 2012;4:025003.

[95] Landers R, Hubner U, Schmelzeisen R, Mulhaupt R. Rapid prototyping of scaffolds derived from thermoreversible hydrogels and tailored for applications in tissue engineering. Biomaterials. $2002 ; 23: 4437-47$.

[96] Cohen DL, Malone E, Lipson H, Bonassar LJ. Direct freeform fabrication of seeded hydrogels in arbitrary geometries. Tissue Eng. 2006;12:1325-35.

[97] Williams JM, Adewunmi A, Schek RM, Flanagan CL, Krebsbach PH, Feinberg SE, et al. Bone tissue engineering using polycaprolactone scaffolds fabricated via selective laser sintering. Biomaterials. 2005;26:4817-27.

[98] Tan KH, Chua CK, Leong KF, Cheah CM, Gui WS, Tan WS, et al. Selective laser sintering of biocompatible polymers for applications in tissue engineering. Bio-medical materials and engineering. 2005;15:113-24.

[99] Niino T, Hamajima D, Montagne K, Oizumi S, Naruke H, Huang H, et al. Laser sintering fabrication of three-dimensional tissue engineering scaffolds with a flow channel network. Biofabrication. 2011;3:034104.

[100] Mazzoli A. Selective laser sintering in biomedical engineering. Medical and biological engineering and computing. 2013;51:245-56. 
[101] Gittard SD, Narayan RJ. Laser direct writing of micro- and nano-scale medical devices. Expert review of medical devices. 2010;7:343-56.

[102] Schuller-Ravoo S, Feijen J, Grijpma DW. Preparation of flexible and elastic poly(trimethylene carbonate) structures by stereolithography. Macromolecular bioscience. 2011;11:1662-71.

[103] Cooke MN, Fisher JP, Dean D, Rimnac C, Mikos AG. Use of stereolithography to manufacture critical-sized 3D biodegradable scaffolds for bone ingrowth. Journal of biomedical materials research Part B, Applied biomaterials. 2003;64:65-9.

[104] Skoog SA, Goering PL, Narayan RJ. Stereolithography in tissue engineering. Journal of materials science Materials in medicine. 2013;25:845-56.

[105] Moroni L, Licht R, de Boer J, de Wijn JR, van Blitterswijk CA. Fiber diameter and texture of electrospun PEOT/PBT scaffolds influence human mesenchymal stem cell proliferation and morphology, and the release of incorporated compounds. Biomaterials. 2006;27:4911-22.

[106] Lannutti J, Reneker D, Ma T, Tomasko D, Farson DF. Electrospinning for tissue engineering scaffolds. Materials Science and Engineering C-Biomimetic and Supramolecular Systems. $2007 ; 27: 504-9$.

[107] Li D, Xia YN. Electrospinning of nanofibers: Reinventing the wheel? Advanced Materials. 2004;16:1151-70.

[108] Kasuga T, Sawada M, Nogami M, Abe Y. Bioactive ceramics prepared by sintering and crystallization of calcium phosphate invert glasses. Biomaterials. 1999;20:1415-20.

[109] Arita IH, Wilkinson DS, Mondragon MA, Castano VM. Chemistry and sintering behaviour of thin hydroxyapatite ceramics with controlled porosity. Biomaterials. 1995;16:403-8.

[110] Rusnah M, Andanastuti M, Idris B. The influence of sintering temperature on the porosity and strength of porous hydroxyapatite ceramics. The Medical journal of Malaysia. 2004;59 Suppl B:158-9.

[111] Solchaga LA, Tognana E, Penick K, Baskaran H, Goldberg VM, Caplan AI, et al. A rapid seeding technique for the assembly of large cell/scaffold composite constructs. Tissue Eng. 2006;12:1851-63.

[112] Harrison BS, Eberli D, Lee SJ, Atala A, Yoo JJ. Oxygen producing biomaterials for tissue regeneration. Biomaterials. 2007;28:4628-34.

[113] Causa F, Netti PA, Ambrosio L. A multi-functional scaffold for tissue regeneration: The need to engineer a tissue analogue. Biomaterials. 2007;28:5093-9.

[114] Du Y, Ghodousi M, Lo E, Vidula MK, Emiroglu O, Khademhosseini A. Surface-directed assembly of cell-laden microgels. Biotechnol Bioeng. 2010;105:655-62.

[115] Leferink A, Schipper D, Arts E, Vrij E, Rivron N, Karperien M, et al. Engineered MicroObjects as Scaffolding Elements in Cellular Building Blocks for Bottom-Up Tissue Engineering Approaches. Adv Mater. 2014:26:2592-9.

[116] Chen T, Zhang ZL, Glotzer SC. A precise packing sequence for self-assembled convex structures. Proceedings of the National Academy of Sciences of the United States of America. 2007;104:717-22.

[117] Yanagawa F, Kaji H, Jang YH, Bae H, Yanan D, Fukuda J, et al. Directed assembly of cell-laden microgels for building porous three-dimensional tissue constructs. Journal of biomedical materials research. 2011;97:93-102. 
[118] Lee HS, Teng SW, Chen HC, Lo W, Sun Y, Lin TY, et al. Imaging human bone marrow stem cell morphogenesis in polyglycolic acid scaffold by multiphoton microscopy. Tissue Eng. $2006 ; 12: 2835-41$.

[119] Appel AA, Anastasio MA, Larson JC, Brey EM. Imaging challenges in biomaterials and tissue engineering. Biomaterials. 2013;34:6615-30.

[120] Georgakoudi I, Rice WL, Hronik-Tupaj M, Kaplan DL. Optical spectroscopy and imaging for the noninvasive evaluation of engineered tissues. Tissue Eng Part B Rev. 2008;14:321-40.

[121] Boyde A, Jones SJ. Scanning electron microscopy of bone: Instrument, specimen, and issues. Microscopy research and technique. 1996;33:92-120. [122] Cai X, Zhang YS, Xia Y, Wang LV. Photoacoustic Microscopy in Tissue Engineering. Materials today. 2013;16:67-77.

[123] Mestres P, Putz N, de las Heras SGG, Poblete EG, Morguet A, Laue M. The surface topography of the choroid plexus. Environmental, low and high vacuum scanning electron microscopy. Ann Anat. 2011;193:197-204.

[124] McGregor JE, Donald AM. The application of ESEM to biological samples. J Phys Conf Ser. 2010;241.

[125] Donald AM. The use of environmental scanning electron microscopy for imaging wet and insulating materials. Nature Materials. 2003;2:511-6.

[126] Doyle V, Pearson R, Lee D, Wolowacz S, McTaggart S. An investigation of the growth of human dermal fibroblasts on poly-L-lactic acid in vitro. J Mater Sci-Mater M. 1996;7:381-5.

[127] Yan D, Jones J, Yuan XY, Xu XH, Sheng J, Lee JCM, et al. Plasma Treatment of Random and Aligned Electrospun PCL Nanofibers. J Med Biol Eng. 2013;33:171-8.

[128] Soldani P, Pellegrini A, Gesi M, Lenzi P, Cristofani R, Paparelli A. SEM/TEM investigation of rat cardiac subcellular alterations induced by changing duration of noise stress. Anat Rec. 1997;248:521-32.

[129] Machac J. Cardiac positron emission tomography imaging. Seminars in nuclear medicine. 2005;35:17-36.

[130] Talukdar Y, Avti PK, Sun J, Sitharaman B. Multimodal Ultrasound-Photoacoustic Imaging of Tissue Engineering Scaffolds and Blood Oxygen Saturation In and Around the Scaffolds. Tissue Eng Part C Methods. 2014;20:440-9.

[131] Wolfs E, Struys T, Notelaers T, Roberts SJ, Sohni A, Bormans G, et al. 18F-FDG labeling of mesenchymal stem cells and multipotent adult progenitor cells for PET imaging: effects on ultrastructure and differentiation capacity. J Nucl Med. 2013;54:447-54.

[132] Chouinard JA, Rousseau JA, Beaudoin JF, Vermette P, Lecomte R. Positron emission tomography detection of human endothelial cell and fibroblast monolayers: effect of pretreament and cell density on 18FDG uptake. Vascular cell. 2012;4:5.

[133] Adonai N, Nguyen KN, Walsh J, Iyer M, Toyokuni T, Phelps ME, et al. Ex vivo cell labeling with 64Cu-pyruvaldehyde-bis(N4-methylthiosemicarbazone) for imaging cell trafficking in mice with positron-emission tomography. Proc Natl Acad Sci U S A. 2002;99:3030-5.

[134] Doyle B, Kemp BJ, Chareonthaitawee P, Reed C, Schmeckpeper J, Sorajja P, et al. Dynamic tracking during intracoronary injection of 18F-FDG-labeled progenitor cell therapy for acute myocardial infarction. J Nucl Med. 2007;48:1708-14.

[135] Souron JB, Petiet A, Decup F, Tran XV, Lesieur J, Poliard A, et al. Pulp cell tracking by 
radionuclide imaging for dental tissue engineering. Tissue Eng Part C Methods. 2014;20:188-97.

[136] Polyak A, Hajdu I, Bodnar M, Trencsenyi G, Postenyi Z, Haasz V, et al. (99m)Tc-labelled nanosystem as tumour imaging agent for SPECT and SPECT/CT modalities. Int J Pharm. 2013;449:10-7.

[137] Belmar-Lopez C, Mendoza G, Oberg D, Burnet J, Simon C, Cervello I, et al. Tissue-derived mesenchymal stromal cells used as vehicles for anti-tumor therapy exert different in vivo effects on migration capacity and tumor growth. Bmc Med. 2013;11:139.

[138] Koba W, Kim K, Lipton ML, Jelicks L, Das B, Herbst L, et al. Imaging devices for use in small animals. Seminars in nuclear medicine. 2011;41:151-65. [139] Khmelinskii A, Groen HC, Baiker M, de Jong M, Lelieveldt BP. Segmentation and visual analysis of whole-body mouse skeleton microSPECT. Plos One. 2012;7:e48976.

[140] Jaiswal M, Koul V, Dinda AK, Mohanty S, Jain KG. Cell adhesion and proliferation studies on semi-interpenetrating polymeric networks (semi-IPNs) of polyacrylamide and gelatin. Journal of biomedical materials research Part B, Applied biomaterials. 2011;98:342-50.

[141] Saeidi N, Guo X, Hutcheon AE, Sander EA, Bale SS, Melotti SA, et al. Disorganized collagen scaffold interferes with fibroblast mediated deposition of organized extracellular matrix in vitro. Biotechnol Bioeng. 2012;109:2683-98.

[142] Friedl P. Dynamic imaging of cellular interactions with extracellular matrix. Histochemistry and cell biology. 2004;122:183-90.

[143] Quentmeier S, Denicke S, Gericke KH. Two-color two-photon fluorescence laser scanning microscopy. Journal of fluorescence. 2009;19:1037-43.

[144] Martin I, Mastrogiacomo M, De Leo G, Muraglia A, Beltrame F, Cancedda R, et al. Fluorescence microscopy imaging of bone for automated histomorphometry. Tissue Eng. 2002;8:847-52.

[145] Calle EA, Vesuna S, Dimitrievska S, Zhou K, Huang A, Zhao L, et al. The Use of Optical Clearing and Multiphoton Microscopy for Investigation of Three-Dimensional Tissue-Engineered Constructs. Tissue Eng Part C Methods. 2014;DOI:10.1089/ten.tec.2013.0538.

[146] Turchin IV, Kamensky VA, Plehanov VI, Orlova AG, Kleshnin MS, Fiks, II, et al. Fluorescence diffuse tomography for detection of red fluorescent protein expressed tumors in small animals. J Biomed Opt. 2008;13:041310.

[147] Farwell DG, Meier JD, Park J, Sun Y, Coffman H, Poirier B, et al. Time-resolved fluorescence spectroscopy as a diagnostic technique of oral carcinoma: Validation in the hamster buccal pouch model. Archives of otolaryngology-head and neck surgery. 2010;136:126-33.

[148] Wagnieres GA, Star WM, Wilson BC. In vivo fluorescence spectroscopy and imaging for oncological applications. Photochemistry and photobiology. 1998;68:603-32.

[149] Leblond F, Davis SC, Valdes PA, Pogue BW. Pre-clinical whole-body fluorescence imaging: Review of instruments, methods and applications. Journal of photochemistry and photobiology B, Biology. 2010;98:77-94.

[150] Yang M, Jiang P, Hoffman RM. Whole-body subcellular multicolor imaging of tumor-host interaction and drug response in real time. Cancer Res. 2007;67:5195-200.

[151] Steyer GJ, Roy D, Salvado O, Stone ME, Wilson DL. Cryo-Imaging of Fluorescently-Labeled Single Cells in a Mouse. Proceedings - Society of Photo-Optical Instrumentation Engineers. 2009;7262:72620W-W8. 
[152] Cowles EA, Kovar JL, Curtis ET, Xu H, Othman SF. Near-infrared optical imaging for monitoring the regeneration of osteogenic tissue-engineered constructs. BioResearch open access. 2013;2:186-91.

[153] Kim SH, Lee JH, Hyun H, Ashitate Y, Park G, Robichaud K, et al. Near-infrared fluorescence imaging for noninvasive trafficking of scaffold degradation. Scientific reports. 2013;3:1198.

[154] de Mel A, Oh JT, Ramesh B, Seifalian AM. Biofunctionalized quantum dots for live monitoring of stem cells: applications in regenerative medicine. Regenerative medicine. 2012;7:335-47.

[155] Yang M, Baranov E, Jiang P, Sun FX, Li XM, Li LN, et al. Whole-body optical imaging of green fluorescent protein-expressing tumors and metastases. Proceedings of the National Academy of Sciences of the United States of America. 2000;97:1206-11.

[156] Hoover EE, Squier JA. Advances in multiphoton microscopy technology. Nat Photonics. 2013;7:93-101.

[157] Kluge JA, Leisk GG, Cardwell RD, Fernandes AP, House M, Ward A, et al. Bioreactor system using noninvasive imaging and mechanical stretch for biomaterial screening. Ann Biomed Eng. 2011;39:1390-402.

[158] Campagnola PJ, Millard AC, Terasaki M, Hoppe PE, Malone CJ, Mohler WA. Threedimensional high-resolution second-harmonic generation imaging of endogenous structural proteins in biological tissues. Biophysical Journal. 2002;82:493-508.

[159] Sun Y, Tan HY, Lin SJ, Lee HS, Lin TY, Jee SH, et al. Imaging tissue engineering scaffolds using multiphoton microscopy. Microscopy research and technique. 2008;71:140-5.

[160] Schenke-Layland K, Riemann I, Damour O, Stock UA, Konig K. Two-photon microscopes and in vivo multiphoton tomographs-powerful diagnostic tools for tissue engineering and drug delivery. Adv Drug Deliv Rev. 2006;58:878-96.

[161] Pena AM, Fagot D, Olive C, Michelet JF, Galey JB, Leroy F, et al. Multiphoton microscopy of engineered dermal substitutes: assessment of 3-D collagen matrix remodeling induced by fibroblast contraction. J Biomed Opt. 2010;15:056018.

[162] Rice WL, Firdous S, Gupta S, Hunter M, Foo CW, Wang Y, et al. Non-invasive characterization of structure and morphology of silk fibroin biomaterials using non-linear microscopy. Biomaterials. 2008;29:2015-24.

[163] Mouras R, Bagnaninchi PO, Downes AR, Elfick APD. Label-free assessment of adipose-derived stem cell differentiation using coherent anti-Stokes Raman scattering and multiphoton microscopy. Journal of Biomedical Optics. 2012;17.

[164] Contag CH, Bachmann MH. Advances in in vivo bioluminescence imaging of gene expression. Annu Rev Biomed Eng. 2002;4:235-60.

[165] Liu J, Hilderink J, Groothuis TA, Otto C, van Blitterswijk CA, de Boer J. Monitoring nutrient transport in tissue-engineered grafts. Journal of tissue engineering and regenerative medicine. 2013;DOI:10.1002/term.1654.

[166] Kammili RK, Taylor DG, Xia J, Osuala K, Thompson K, Menick DR, et al. Generation of novel reporter stem cells and their application for molecular imaging of cardiac-differentiated stem cells in vivo. Stem Cells Dev. 2010;19:1437-48.

[167] Blum JS, Temenoff JS, Park H, Jansen JA, Mikos AG, Barry MA. Development and characterization of enhanced green fluorescent protein and luciferase expressing cell line for non-destructive 
evaluation of tissue engineering constructs. Biomaterials. 2004;25:5809-19.

[168] Leo BM, Li XD, Balian G, Anderson DG. In vivo bioluminescent imaging of virus-mediated gene transfer and transduced cell transplantation in the intervertebral disc. Spine. 2004;29:838-44.

[169] Bar I, Zilberman Y, Zeira E, Galun E, Honigman A, Turgeman G, et al. Molecular imaging of the skeleton: Quantitative real-time bioluminescence monitoring gene expression in bone repair and development. Journal of Bone and Mineral Research. 2003;18:570-8.

[170] Roman I, Vilalta M, Rodriguez J, Matthies AM, Srouji S, Livne E, et al. Analysis of progenitor cell-scaffold combinations by in vivo non-invasive photonic imaging. Biomaterials. 2007;28:2718-28.

[171] Logeart-Avramoglou D, Oudina K, Bourguignon M, Delpierre L, Nicola MA, Bensidhoum M, et al. In vitro and in vivo bioluminescent quantification of viable stem cells in engineered constructs. Tissue Eng Part C Methods. 2010;16:447-58.

[172] Olivo C, Alblas J, Verweij V, Van Zonneveld AJ, Dhert WJ, Martens AC. In vivo bioluminescence imaging study to monitor ectopic bone formation by luciferase gene marked mesenchymal stem cells. Journal of orthopaedic research : official publication of the Orthopaedic Research Society. 2008;26:901-9.

[173] de Boer J, van Blitterswijk C, Lowik C. Bioluminescent imaging: emerging technology for non-invasive imaging of bone tissue engineering. Biomaterials. 2006;27:1851-8.

[174] Clemens TL, Tang H, Maeda S, Kesterson RA, Demayo F, Pike JW, et al. Analysis of osteocalcin expression in transgenic mice reveals a species difference in vitamin $\mathrm{D}$ regulation of mouse and human osteocalcin genes. Journal of Bone and Mineral Research. 1997;12:1570-6.

[175] Bago JR, Aguilar E, Alieva M, Soler-Botija C, Vila OF, Claros S, et al. In vivo bioluminescence imaging of cell differentiation in biomaterials: a platform for scaffold development. Tissue engineering. 2013;19:593-603.

[176] Huang D, Swanson EA, Lin CP, Schuman JS, Stinson WG, Chang W, et al. Optical Coherence Tomography. Science. 1991;254:1178-81.

[177] Yang Y, Dubois A, Qin XP, Li J, El Haj A, Wang RK. Investigation of optical coherence tomography as an imaging modality in tissue engineering. Physics in medicine and biology. 2006;51:1649-59.

[178] Liang X, Graf BW, Boppart SA. Imaging engineered tissues using structural and functional optical coherence tomography. Journal of biophotonics. 2009;2:643-55.

[179] Graf BW, Boppart SA. Imaging and analysis of three-dimensional cell culture models. Methods Mol Biol. 2010;591:211-27.

[180] Yang Y, Bagnaninchi PO, Cunha-Reis C, Aydin HM, Piskin E, El Haj A. Characterisation of scaffold architecture by optical coherence tomography - art. no. 64390G. P Soc Photo-Opt Ins. 2007;6439:G4390-G.

[181] Ozturk MS, Lee VK, Zhao L, Dai G, Intes X. Mesoscopic fluorescence molecular tomography of reporter genes in bioprinted thick tissue. J Biomed Opt. 2013;18:100501.

[182] Tan W, Sendemir-Urkmez A, Fahrner LJ, Jamison R, Leckband D, Boppart SA. Structural and functional optical imaging of three-dimensional engineered tissue development. Tissue engineering. 2004;10:1747-56.

[183] Wang ZG, Pan H, Yuan ZJ, Liu JX, Chen WL, Pan YT. Assessment of dermal wound repair after collagen implantation with optical coherence tomography. Tissue Eng Part C-Me. 
$2008 ; 14: 35-45$.

[184] Bagnaninchi PO, El Haj A, Yang Y. Continuous monitoring of tissue growth inside a perfusion bioreactor by optical coherence tomography - art. no. 643903. P Soc Photo-Opt Ins. 2007;6439:43903-.

[185] Mason C, Markusen JF, Town MA, Dunnill P, Wang RK. Doppler optical coherence tomography for measuring flow in engineered tissue. Biosens Bioelectron. 2004;20:414-23.

[186] Tomlins PH, Wang Y, Zhang B, Tedaldi M, Tomlins PE. Complex flow characterisation of a porous tissue scaffold measured by Doppler optical coherence tomography. Proc Spie. 2008;6858.

[187] Boppart SA. Advanced spectroscopic coherence tomography. Ieee Leos Ann Mtg. 2006:162-3.

[188] Dunkers JP, Lee YJ, Chatterjee K. Single cell viability measurements in 3D scaffolds using in situ label free imaging by optical coherence microscopy. Biomaterials. 2012;33:2119-26.

[189] Kunstar A, Leferink AM, Okagbare PI, Morris MD, Roessler BJ, Otto C, et al. Label-free Raman monitoring of extracellular matrix formation in three-dimensional polymeric scaffolds. J R Soc Interface. 2013;10:20130464.

[190] Brauchle E, Schenke-Layland K. Raman spectroscopy in biomedicine - non-invasive in vitro analysis of cells and extracellular matrix components in tissues. Biotechnology journal. 2013;8:288-97.

[191] Notingher I, Verrier S, Romanska H, Bishop AE, Polak JM, Hench LL. In situ characterisation of living cells by Raman spectroscopy. Spectrosc-Int J. 2002;16:43-51.

[192] Chan JW, Lieu DK, Huser T, Li RA. Label-Free Separation of Human Embryonic Stem Cells and Their Cardiac Derivatives Using Raman Spectroscopy. Analytical chemistry. 2009;81:1324-31.

[193] Schulze HG, Konorov SO, Caron NJ, Piret JM, Blades MW, Turner RFB. Assessing Differentiation Status of Human Embryonic Stem Cells Noninvasively Using Raman Microspectroscopy. Analytical chemistry. 2010;82:5020-7.

[194] Leikin S, Parsegian VA, Yang WH, Walrafen GE. Raman spectral evidence for hydration forces between collagen triple helices. Proceedings of the National Academy of Sciences of the United States of America. 1997;94:11312-7.

[195] Ellis R, Green E, Winlove CP. Structural Analysis of Glycosaminoglycans and Proteoglycans by Means of Raman Microspectrometry. Connect Tissue Res. 2009;50:29-36.

[196] Kunstar A, Leijten J, van Leuveren S, Hilderink J, Otto C, van Blitterswijk CA, et al. Recognizing different tissues in human fetal femur cartilage by label-free Raman microspectroscopy. Journal of Biomedical Optics. 2012;17.

[197] Jones JR, Vats A, Notingher L, Gough JE, Tolley NS, Polak JM, et al. In situ monitoring of chondrocyte response to bioactive scaffolds using Raman spectroscopy. Key Eng Mat. 2005;284286:623-6.

[198] Boyd AR, Burke GA, Meenan BJ. Monitoring cellular behaviour using Raman spectroscopy for tissue engineering and regenerative medicine applications. Journal of materials science Materials in medicine. 2010;21:2317-24.

[199] Mather ML, Crowe JA, Morgan SP, White LJ, Kalashnikov AN, Ivchenko VG, et al. Ultrasonic monitoring of foamed polymeric tissue scaffold fabrication. Journal of materials science Materials in medicine. 2008;19:3071-80.

[200] Kim K, Jeong CG, Hollister SJ. Non-invasive monitoring of tissue scaffold degradation using 
ultrasound elasticity imaging. Acta biomaterialia. 2008;4:783-90.

[201] Rice MA, Waters KR, Anseth KS. Ultrasound monitoring of cartilaginous matrix evolution in degradable PEG hydrogels. Acta biomaterialia. 2009;5:152-61.

[202] Kreitz S, Dohmen G, Hasken S, Schmitz-Rode T, Mela P, Jockenhoevel S. Nondestructive method to evaluate the collagen content of fibrin-based tissue engineered structures via ultrasound. Tissue Eng Part C Methods. 2011;17:1021-6.

[203] Fite BZ, Decaris M, Sun Y, Sun Y, Lam A, Ho CK, et al. Noninvasive multimodal evaluation of bioengineered cartilage constructs combining time-resolved fluorescence and ultrasound imaging. Tissue Eng Part C Methods. 2011;17:495-504.

[204] $\mathrm{Hu}$ S, Wang LV. Neurovascular photoacoustic tomography. Frontiers in neuroenergetics. $2010 ; 2: 10$.

[205] Saha RK, Kolios MC. Effects of erythrocyte oxygenation on optoacoustic signals. J Biomed Opt. 2011;16:115003.

[206] Zhang HF, Maslov K, Stoica G, Wang LV. Functional photoacoustic microscopy for highresolution and noninvasive in vivo imaging. Nat Biotechnol. 2006;24:848-51.

[207] Needles A, Heinmiller A, Sun J, Theodoropoulos C, Bates D, Hirson D, et al. Development and initial application of a fully integrated photoacoustic micro-ultrasound system. IEEE transactions on ultrasonics, ferroelectrics, and frequency control. 2013;60:888-97.

[208] Krumholz A, Shcherbakova DM, Xia J, Wang LV, Verkhusha VV. Multicontrast photoacoustic in vivo imaging using near-infrared fluorescent proteins. Scientific reports. 2014;4:3939.

[209] Wang LHV, Hu S. Photoacoustic Tomography: In Vivo Imaging from Organelles to Organs. Science. 2012;335:1458-62.

[210] Cai X, Li L, Krumholz A, Guo Z, Erpelding TN, Zhang C, et al. Multi-scale molecular photoacoustic tomography of gene expression. Plos One. 2012;7:e43999.

[211] Zhang YS, Cai X, Yao J, Xing W, Wang LV, Xia Y. Non-invasive and in situ characterization of the degradation of biomaterial scaffolds by volumetric photoacoustic microscopy. Angewandte Chemie. 2014;53:184-8.

[212] Wang LV. Multiscale photoacoustic microscopy and computed tomography. Nat Photonics. 2009;3:503-9.

[213] Cai X, Paratala BS, Hu S, Sitharaman B, Wang LV. Multiscale photoacoustic microscopy of single-walled carbon nanotube-incorporated tissue engineering scaffolds. Tissue Eng Part C Methods. 2012;18:310-7.

[214] Zhang Y, Cai X, Choi SW, Kim C, Wang LV, Xia Y. Chronic label-free volumetric photoacoustic microscopy of melanoma cells in three-dimensional porous scaffolds. Biomaterials. 2010;31:8651-8.

[215] Aguirre A, Guo P, Gamelin J, Yan S, Sanders MM, Brewer M, et al. Coregistered threedimensional ultrasound and photoacoustic imaging system for ovarian tissue characterization. J Biomed Opt. 2009;14:054014.

[216] Feldkamp LA, Goldstein SA, Parfitt AM, Jesion G, Kleerekoper M. The direct examination of three-dimensional bone architecture in vitro by computed tomography. Journal of bone and mineral research : the official journal of the American Society for Bone and Mineral Research. 1989;4:3-11.

[217] Kerckhofs G, Sainz J, Wevers M, Van de Putte T, Schrooten J. Contrast-enhanced nanofocus 
computed tomography images the cartilage subtissue architecture in three dimensions. Eur Cell Mater. 2013;25:179-89.

[218] Baino F, Vitale-Brovarone C. Three-dimensional glass-derived scaffolds for bone tissue engineering: current trends and forecasts for the future. Journal of biomedical materials research. 2011;97:514-35.

[219] Meleo D, Bedini R, Pecci R, Mangione F, Pacifici L. Microtomographic and morphometric characterization of a bioceramic bone substitute in dental implantology. Annali dell'Istituto superiore di sanita. 2012;48:59-64.

[220] Barbetta A, Bedini R, Pecci R, Dentini M. Role of X-ray microtomography in tissue engineering. Ann I Super Sanita. 2012;48:10-8.

[221] Dorsey SM, Lin-Gibson S, Simon CG, Jr. X-ray microcomputed tomography for the measurement of cell adhesionand proliferation in polymer scaffolds. Biomaterials. 2009;30:2967-74.

[222] Jones GL, Walton R, Czernuszka J, Griffiths SL, El Haj AJ, Cartmell SH. Primary human osteoblast culture on 3D porous collagen-hydroxyapatite scaffolds. Journal of biomedical materials research. 2010;94:1244-50.

[223] Voronov RS, VanGordon SB, Shambaugh RL, Papavassiliou DV, Sikavitsas VI. 3D tissueengineered construct analysis via conventional high-resolution microcomputed tomography without X-ray contrast. Tissue Eng Part C Methods. 2013;19:327-35.

[224] Appel A, Anastasio MA, Brey EM. Potential for imaging engineered tissues with X-ray phase contrast. Tissue Eng Part B Rev. 2011;17:321-30.

[225] Zhu N, Chapman D, Cooper D, Schreyer DJ, Chen X. X-ray diffraction enhanced imaging as a novel method to visualize low-density scaffolds in soft tissue engineering. Tissue Eng Part $\mathrm{C}$ Methods. 2011;17:1071-80.

[226] Xu HH, Othman SF, Magin RL. Monitoring Tissue Engineering Using Magnetic Resonance Imaging. J Biosci Bioeng. 2008;106:515-27.

[227] Yang CY, Hsiao JK, Tai MF, Chen ST, Cheng HY, Wang JL, et al. Direct Labeling of hMSC with SPIO: the Long-Term Influence on Toxicity, Chondrogenic Differentiation Capacity, and Intracellular Distribution. Mol Imaging Biol. 2011;13:443-51.

[228] Kubinova S, Sykova E. Nanotechnologies in regenerative medicine. Minimally invasive therapy and allied technologies : MITAT : official journal of the Society for Minimally Invasive Therapy. 2010;19:144-56.

[229] Di Corato R, Gazeau F, Le Visage C, Fayol D, Levitz P, Lux F, et al. High-Resolution Cellular MRI: Gadolinium and Iron Oxide Nanoparticles for in-Depth Dual-Cell Imaging of Engineered Tissue Constructs. ACS Nano. 2013;7:7500-12.

[230] Narayan S, Huang FP, Johnson D, Gargesha M, Flask CA, Zhang GQ, et al. Fast Lipid and Water Levels by Extraction With Spatial Smoothing (FLAWLESS): Three-Dimensional Volume Fat/Water Separation at 7 Tesla. J Magn Reson Imaging. 2011;33:1464-73.

[231] Lalande C, Miraux S, Derkaoui SM, Mornet S, Bareille R, Fricain JC, et al. Magnetic Resonance Imaging Tracking of Human Adipose Derived Stromal Cells within Three-Dimensional Scaffolds for Bone Tissue Engineering. Eur Cells Mater. 2011;21:341-54.

[232] Xu HH, Othman SF, Hong L, Peptan IA, Magin RL. Magnetic resonance microscopy for monitoring osteogenesis in tissue-engineered construct in vitro. Physics in medicine and biology. 
2006;51:719-32.

[233] Peptan IA, Hong L, Xu HH, Magin RL. MR assessment of osteogenic differentiation in tissue-engineered constructs. Tissue engineering. 2006;12:843-51.

[234] Hong L, Peptan IA, Xu HH, Magin RL. Nondestructive evaluation of osteogenic differentiation in tissue-engineered constructs. Journal of Orthopaedic Research. 2006;24:889-97.

[235] Miyata S, Numano T, Tateishic T, Ushida T. Feasibility of noninvasive evaluation of biophysical properties of tissue-engineered cartilage by using quantitative MRI. Journal of biomechanics. 2007;40:2990-8.

[236] Washburn NR, Weir M, Anderson P, Potter K. Bone formation in polymeric scaffolds evaluated by proton magnetic resonance microscopy and X-ray microtomography. Journal of Biomedical Materials Research Part A. 2004;69A:738-47.

[237] Chesnick IE, Mason JT, Giuseppetti AA, Eidelman N, Potter K. Magnetic resonance microscopy of collagen mineralization. Biophysical Journal. 2008;95:2017-26.

[238] Nissi MJ, Rieppo J, Toyras J, Laasanen MS, Kiviranta I, Jurvelin JS, et al. T(2) relaxation time mapping reveals age- and species-related diversity of collagen network architecture in articular cartilage. Osteoarthritis Cartilage. 2006;14:1265-71.

[239] Xia Y, Moody JB, Burton-Wurster N, Lust G. Quantitative in situ correlation between microscopic MRI and polarized light microscopy studies of articular cartilage. Osteoarthritis Cartilage. 2001;9:393-406.

[240] Mountain KM, Bjarnason TA, Dunn JF, Matyas JR. The functional microstructure of tendon collagen revealed by high-field MRI. Magnetic resonance in medicine : official journal of the Society of Magnetic Resonance in Medicine / Society of Magnetic Resonance in Medicine. 2011;66:520-7.

[241] Crowe JJ, Grant SC, Logan TM, Ma T. A magnetic resonance-compatible perfusion bioreactor system for three-dimensional human mesenchymal stem cell construct development. Chem Eng Sci. 2011;66:4138-47.

[242] Gottwald E, Kleintschek T, Giselbrecht S, Truckenmuller R, Altmann B, Worgull M, et al. Characterization of a chip-based bioreactor for three-dimensional cell cultivation via Magnetic Resonance Imaging. Zeitschrift fur medizinische Physik. 2013;23:102-10.

[243] Ramaswamy S, Greco JB, Uluer MC, Zhang ZJ, Zhang ZL, Fishbein KW, et al. Magnetic Resonance Imaging of Chondrocytes Labeled with Superparamagnetic Iron Oxide Nanoparticles in Tissue-Engineered Cartilage. Tissue Eng Pt A. 2009;15:3899-910.

[244] Feng Y, Jin X, Dai G, Liu J, Chen J, Yang L. In vitro targeted magnetic delivery and tracking of superparamagnetic iron oxide particles labeled stem cells for articular cartilage defect repair. Journal of Huazhong University of Science and Technology Medical sciences. 2011;31:204-9.

[245] Tran LA, Krishnamurthy R, Muthupillai R, Cabreira-Hansen Mda G, Willerson JT, Perin EC, et al. Gadonanotubes as magnetic nanolabels for stem cell detection. Biomaterials. 2010;31:948291.

[246] Ferreira L. Nanoparticles as tools to study and control stem cells. J Cell Biochem. 2009;108:746-52.

[247] Bhirde A, Xie J, Swierczewska M, Chen X. Nanoparticles for cell labeling. Nanoscale. 2011;3:142-53.

[248] Hachani R, Lowdell M, Birchall M, Thanh NTK. Tracking stem cells in tissue-engineered 
organs using magnetic nanoparticles. Nanoscale. 2013;5:11362-73.

[249] Yang CY, Tai MF, Chen ST, Wang YT, Chen YF, Hsiao JK, et al. Labeling of human mesenchymal stem cell: Comparison between paramagnetic and superparamagnetic agents. J Appl Phys. 2009;105:-.

[250] Harrington JK, Chahboune H, Criscione JM, Li AY, Hibino N, Yi T, et al. Determining the fate of seeded cells in venous tissue-engineered vascular grafts using serial MRI. Faseb J. 2011;25:4150-61.

[251] Kraitchman DL, Gilson WD, Lorenz CH. Stem cell therapy: MRI guidance and monitoring. J Magn Reson Imaging. 2008;27:299-310.

[252] Nitzsche H, Metz H, Lochmann A, Bernstein A, Hause G, Groth T, et al. Characterization of Scaffolds for Tissue Engineering by Benchtop-Magnetic Resonance Imaging. Tissue Eng Part C-Me. 2009;15:513-21.

[253] Wang L, Acosta MA, Leach JB, Carrier RL. Spatially monitoring oxygen level in 3D microfabricated cell culture systems using optical oxygen sensing beads. Lab on a chip. 2013;13:1586-92.

[254] Dvir T, Timko BP, Kohane DS, Langer R. Nanotechnological strategies for engineering complex tissues. Nat Nanotechnol. 2011;6:13-22.

[255] Stern E, Klemic JF, Routenberg DA, Wyrembak PN, Turner-Evans DB, Hamilton AD, et al. Label-free immunodetection with CMOS-compatible semiconducting nanowires. Nature. 2007;445:519-22.

[256] Duan X, Fu TM, Liu J, Lieber CM. Nanoelectronics-biology frontier: From nanoscopic probes for action potential recording in live cells to three-dimensional cyborg tissues. Nano today. 2013;8:351-73.

[257] Tian B, Liu J, Dvir T, Jin L, Tsui JH, Qing Q, et al. Macroporous nanowire nanoelectronic scaffolds for synthetic tissues. Nat Mater. 2012;11:986-94. 
Part I

Cell fate in 3D tissue engineered constructs 


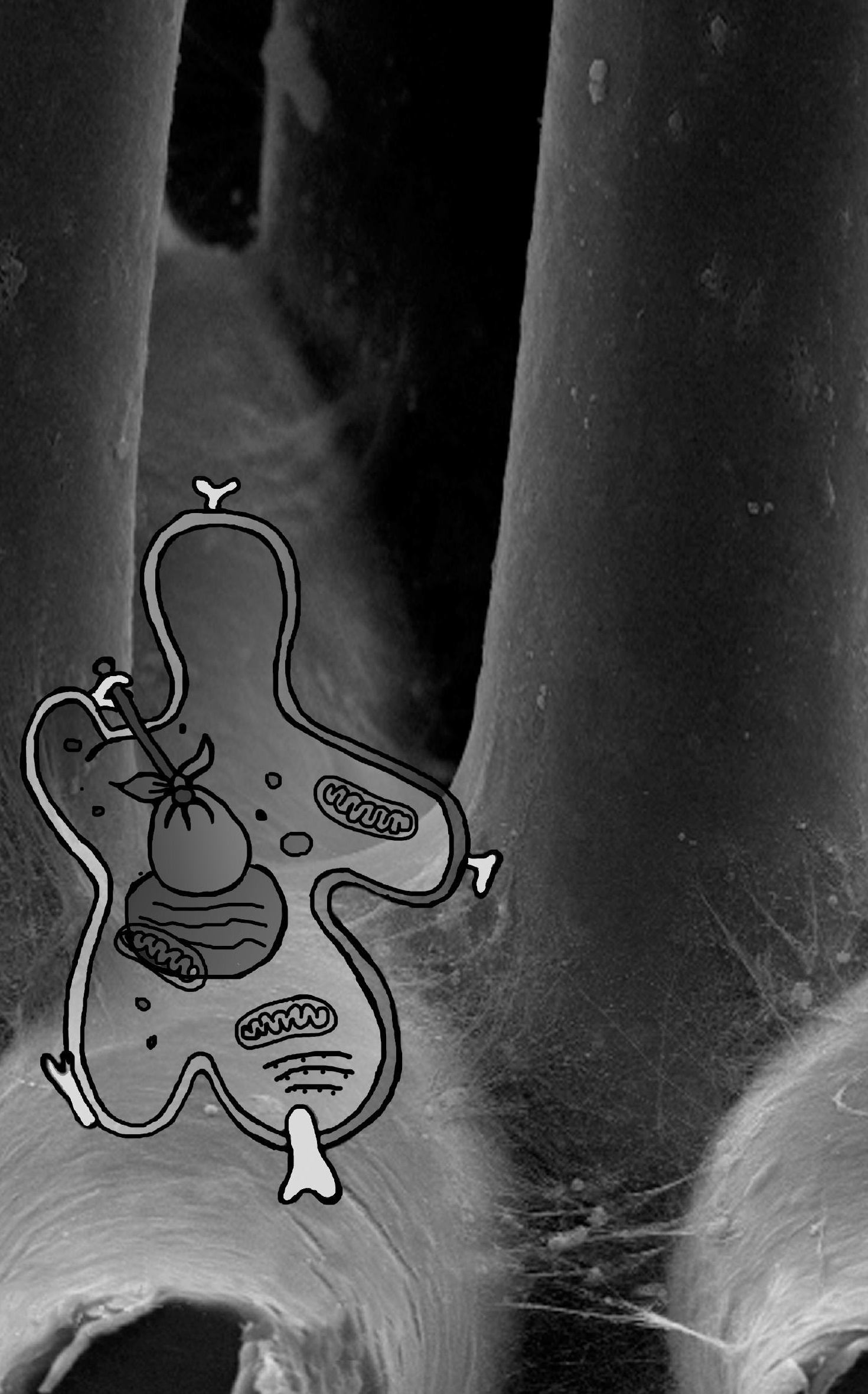




\section{Chapter 3}

\section{Increased cell seeding efficiency in bioplotted 3D PEOT/PBT scaffolds}

A. M. Leferink ${ }^{1}$, W. J. Hendrikson ${ }^{1}$, J. Rouwkema ${ }^{2}$, M. Karperien ${ }^{1,3}$, C. A. van Blitterswijk ${ }^{1}$, L. $^{2}$ Moroni $^{1}$

${ }^{1}$ Department of Tissue Regeneration, ${ }^{2}$ Laboratory of Biomechanical Engineering, ${ }^{3}$ Present address: Department of Developmental Bioengineering of MIRA - Institute for Biomedical Technology and Technical Medicine, University of Twente, Drienerlolaan 5, 7522 NB Enschede, The Netherlands

Published: Journal of Tissue Engineering and Regenerative Medicine,2013,DOI:10.1002/term.1842 


\begin{abstract}
In regenerative medicine studies, cell seeding efficiency (CSE) is not only optimized by changing the chemistry of the biomaterials used as cell culture substrates, but also by altering scaffold geometry, culture and seeding conditions. In this study, the importance of seeding parameters, such as initial cell number, seeding volume, seeding concentration and seeding condition is shown. Human mesenchymal stem cells (hMSCs) were seeded into cylindrically-shaped $4 \times 3 \mathrm{~mm}$ sized polymeric scaffolds, fabricated by fused deposition modeling. The initial cell number ranged from $5 \times 10^{4}$ up to $8 \times 10^{5}$ cells, in volumes varying from 50 up to $400 \mu \mathrm{L}$. To study the effect of seeding conditions, a dynamic system, by means of an agitation plate, was compared to static culture for both scaffolds placed in a well plate or in a confined agarose molded well. CSE decreased when seeded with high initial cell numbers, whereas $2 \times 10^{5}$ cells seemed to be an optimal initial cell number in the scaffolds used here. The influence of seeding volume showed to be dependent on the initial cell number used. By optimizing seeding parameters for each specific culture system, a more efficient use of donor cells can be achieved.
\end{abstract}

Keywords: Cell seeding efficiency, bone marrow stromal cells, rapid prototyping 


\subsection{Introduction}

Tissue Engineering aims at applying the principles of biology and engineering to develop functional substitutes to replace damaged or lost tissue [1]. A typical tissue engineering approach consists of combining autologous cells with a synthetic or biological material, which provides a mechanically stable environment to culture a substitute graft in vitro before implantation. Many researchers have already managed to control chemical, mechanical and physical properties of these biomaterials by various fabrication methods. One of the biomaterials and methods showing high potential in tissue engineering applications are poly(ethylene oxide terephthalate)/poly(butylene terephthalate) (PEOT/PBT) copolymer scaffolds processed by fused deposition modeling [2-5]. PEOT/PBT copolymers have been extensively studied and proved to be biocompatible both in vitro and in vivo [6-8]. These biomaterials have reached clinical applications (PolyActive ${ }^{\mathrm{TM}}$, IsoTis Orthopaedics S.A.) as dermal substitutes [9] and bone fillers $[10,11]$. More recently, rapid prototyped scaffolds from PEOT/PBT copolymers have been investigated for bone and cartilage regeneration therapies and showed potential to be translated into tissue engineered clinical treatments [2, 12-14]. Although the in vitro and in vivo results with these scaffolds were promising, in most cases mature differentiated cells were used. These cell types tend to lose their phenotype upon expansion by de-differentiation, resulting in a decreased functionality of the cells which lowers their potential to secrete functional natural tissue within the scaffold.

To overcome this problem, the use of multipotent cell types from autologous source is opted to be promising. One of the cell types that show high potential in this approach are adult progenitor cells from bone marrow stroma, often referred to as mesenchymal stem cells or stromal cells (MSCs). MSCs are a heterogeneous population of plastic-adherent, fibroblast-like cells, from which the progenitor cells in culture are able to self-renew and differentiate into multiple lineages [15, 16]. Recent studies showed that combining human MSCs and biomaterials with controlled properties, or by adding certain growth factors, differentiation towards chondrogenic [17, 18], osteogenic [19, 20], myogenic [21], adipogenic [22, 23] endothelial [24], and neurogenic [25] lineage can be achieved. Distribution and adherence of cells in scaffolds play a crucial role in the efficiency of tissue engineering approaches. To achieve proper cell penetration into a porous scaffold, the formation of large cell aggregates should be prevented. Unfortunately, even in the absence of cell aggregate formation, cell penetration and therewith a homogeneous spatial distribution of cells throughout the scaffold is often limited.

Another challenge is that the availability of autologous donor cells and their expansion capacity without losing functionality is limited [26]. For human MSCs expanded on tissue culture treated polystyrene the influence of passage number on the multipotency is well studied. For three-dimensional (3D) culture systems the relation between cell density, metabolism and growth kinetics are well-determined, but less is known about the maintenance of differentiation capacity upon expansion [27]. We assume that trends found in two-dimensions (2D) with respect to the correlation between plating density and differentiation potential can be translated to some 3D carriers as well. This is due to the fact that some $3 \mathrm{D}$ scaffolds could, on the cellular level, still 
be considered as 2D when their characteristic dimension (e.g. fiber diameter, strut thickness) is typically an order of magnitude larger than cell dimensions. To be sure cells retain multipotency, the expansion culture time and passage number should be as low as possible. Therefore, it is of high importance to reduce the loss of cells during seeding on the scaffold and in vitro culture [28].

Optimization of cell seeding procedures for various tissue engineering approaches is well studied. CSE of mouse derived mesenchymal cells was compared, for example, on several types of scaffolds using dynamic culture systems, where differences in CSE seemed to be dependent on the chemistry of the carrier material $[29,30]$. In recent studies, CSE was not only optimized by changing chemistry. The CSE can be dependent on scaffold geometry, and on culture [27] and seeding conditions [28, 31, 32] which was shown for hMSCs and MC3T3 cells. In a study of Wang et al., human MSCs derived from umbilical cord were seeded with various densities on non-woven polyglycolic acid meshes and cultured in an orbital shaker for fibrocartilage tissue engineering. Within the first week of culture higher seeding densities did not lead to higher CSE, but did result in significantly higher cell numbers after 4 weeks of culture [33]. Studies of Wendt and Grayson reported an increase in CSE as well as a more homogeneous cellular distribution after seeding in a perfusion bioreactor. The scaffolds used were non-woven meshes and ceramic disks, and decellularized bone tissue respectively which are very distinct architectures compared to regular 3D fused deposition modeled scaffolds $[32,34]$. Previous studies from our group have shown that spinner flasks are a simple solution to dynamically seed cells homogeneously throughout 3D fused deposition modeled PEOT/PBT scaffolds. However, these studies were performed with bovine and human chondrocytes, which are much broadly available than human MSCs. Therefore, cell loss did not form any concern and was compensated with high seeding densities of $3 \times 10^{6}$ cells per scaffold [2].

Despite all these efforts, there are no studies reporting on the influence of basic seeding parameters on seeding efficiency of human MSCs when seeded on 3D fused deposition modeled scaffolds of synthetic polymers. Here, we show the importance of optimizing seeding parameters as cell number, seeding volume and methods as dynamic versus static seeding, to reduce cell loss during seeding. This will ultimately result in more efficient protocols for stem cell based regenerative medicine applications combining a clinically relevant cell source like human MSCs with 3D scaffolds that have shown promising results due to their versatility in structural and architectural customization $[35,36]$. Optimization and control of these seeding parameters will lead to an improvement of good manufacturing practice production and therewith enable the culture of clinically relevant implants.

\subsection{Materials and Methods}

\subsubsection{Isolation of human bone marrow derived stromal cells}

Bone marrow aspirates were obtained from patients who had given written informed consent. hMSCs referred to as donor 1,2 and 3 were isolated and proliferated as described previously [37] unless stated otherwise. Briefly, aspirates from three donors (1: male age 73,2 : female age 77 and 3: female age 55) were resuspended using a 
20-gauge needle, plated at a density of $5 \times 10^{5}$ cells $/ \mathrm{cm}^{2}$ and cultured in proliferation medium, which contains minimal essential medium (alpha-MEM, Life Technologies, Gaithersburg, MD), 10\% heat-inactivated fetal bovine serum (FBS; Lonza), 0.2 mM L-Ascorbic acid 2-phosphate magnesium salt (ASAP, Sigma Aldrich), 2 mM Lglutamine (L-glut, Invitrogen), $100 \mathrm{U} / \mathrm{mL}$ penicillin (Life Technologies), $100 \mu \mathrm{g} / \mathrm{mL}$ streptomycin (Life Technologies) and $1 \mathrm{ng} / \mathrm{mL}$ basic fibroblast growth factor (bFGF; Instruchemie, Delfzijl, The Netherlands). Cells were grown at $37^{\circ} \mathrm{C}$ in a humidified atmosphere with $5 \% \mathrm{CO}_{2}$. Medium was refreshed twice per week and cells were used for further subculturing or cryopreservation on reaching near confluence.

As a control group representing a less heterogeneous cell population, colony-picked hMSCs (male age 22) were retrieved from the Institute of Regenerative Medicine (Temple, Texas) [38, 39]. Briefly, a bone marrow aspirate was drawn and mononuclear cells were separated using density centrifugation. The cells were plated to obtain adherent human marrow stromal cells, which were harvested when cells reached $60 \%$ $80 \%$ confluence. These were considered passage zero (P0) cells. These P0 cells were expanded, harvested and frozen at passage 1 (P1) for distribution.

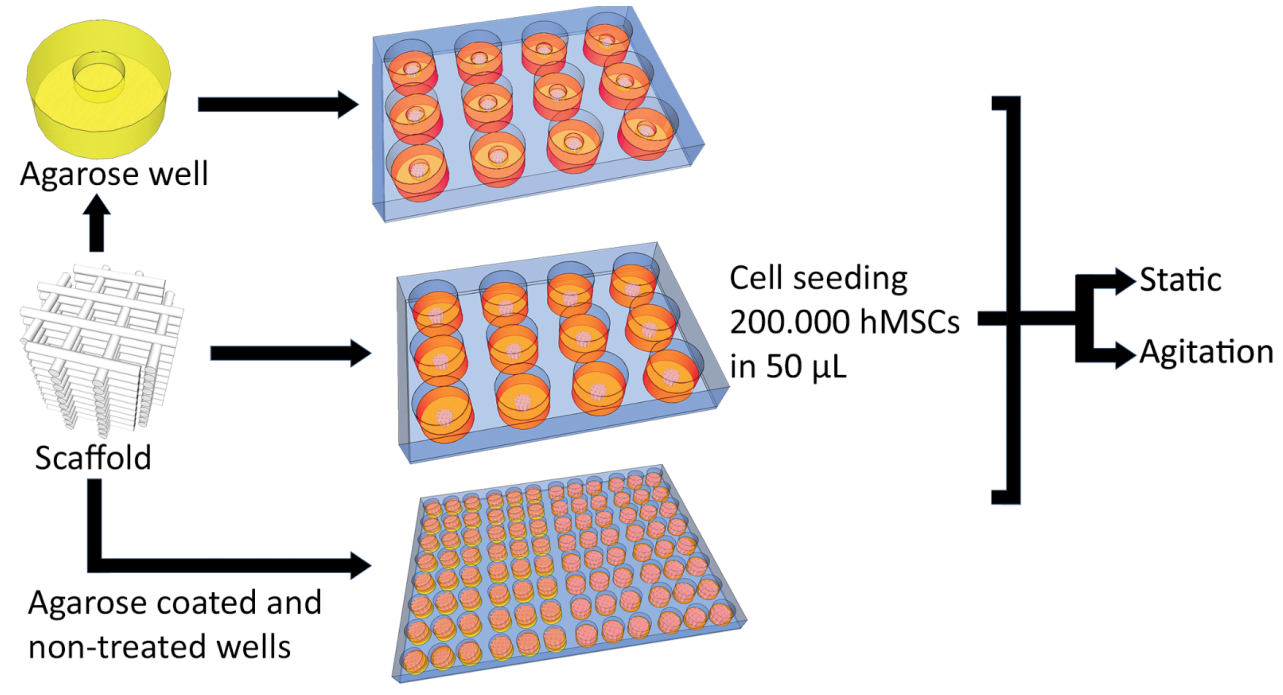

Figure 3.1: Schematic overview of experimental set-up to compare cell seeding efficiency on scaffolds in confined agarose wells, on scaffolds in a polystyrene well-plate and on scaffolds in an agarose coated well. Additionally the influence of agitation during the first 24 hours of culture was compared to static culture.

\subsubsection{Scaffolds fabrication}

Poly(ethylene oxide terephthalate)/poly(butylene terephthalate) (PEOT/PBT) block copolymers were obtained from PolyVation B.V. (The Netherlands). For this study, we used a 300/55/45 PEOT/PBT composition with a weight ratio of 55 PEOT to 45 PBT, and a molecular weight of the starting poly(ethylene glycol) (PEG) segments of $300 \mathrm{Da}$ used in the co-polymerization process. 
3D regular grids were fabricated as described before [40] by fused deposition modeling with a bioscaffolder (SysENG, Germany). For CSE studies, grids were fabricated with a fiber diameter of approximately $250\left(\mathrm{~d}_{1}\right)$, a fiber to fiber distance (fiber spacing) of $800 \mu \mathrm{m}\left(\mathrm{d}_{2}\right)$, and a layer thickness of $150 \mu \mathrm{m}\left(\mathrm{d}_{3}\right)$. Cylindrical porous scaffolds of $4 \mathrm{~mm}$ in diameter by $3 \mathrm{~mm}$ in height were punched out of the produced 3D regular grids. The porosity of these scaffolds is given by equation 3.1 from a theoretical approach [41]:

$$
P=1-\frac{\pi}{4} \times \frac{1}{\frac{d_{2}}{d_{1}}} \times \frac{1}{\frac{d_{3}}{d_{1}}}
$$

This results in scaffolds with porosity of $62 \%$, corresponding to a total pore volume of approximately $23 \mu \mathrm{L}$ per scaffold.

To investigate the effect of scaffolds porosity, scaffolds were fabricated with changing parameters. The scaffold 'standard' refers to the scaffolds with the previous mentioned parameters. Scaffolds with 'thin' or 'thick' fibers refer to changing $\left(\mathrm{d}_{1}\right)$ to 127 \pm 65 and $264 \pm 85 \mu \mathrm{m}$ resulting in porosities of $90 \%$ and $48 \%$ respectively. Scaffolds with small fiber to fiber distance refer to changing $\left(\mathrm{d}_{1}\right)$ and $\left(\mathrm{d}_{2}\right)$ to $208 \pm 16$ and 650 $\pm 12 \mu \mathrm{m}$ respectively, resulting in a porosity of $65 \%$.

All scaffolds were sterilized in $70 \%$ ethanol 2 times for 30 minutes each, washed in PBS first for 5 minutes and additionally for other 30 minutes two times, and finally incubated in culture medium overnight prior to cell culture.

\subsubsection{Cell seeding and culture on scaffolds}

To study CSE, the pre-wetted scaffolds were dried and transferred to non-treated 48-well plates (Nunc). hMSCs (donor 1-3 at passage 3; donor 4 at passage 4 ), were harvested from monolayer expansion by trypsinization, seeded in proliferation medium on top of the scaffolds and resuspended gently to fill all the pores of the scaffold. Small volumes up to $100 \mu \mathrm{L}$ retained mostly inside the scaffolds pores and on top of the scaffolds. Volumes higher than $100 \mu \mathrm{L}$ also resided around the scaffolds on the bottom of the culture well. The number of cells was varied from $5 \times 10^{4}$ up to $8 \times$ $10^{5}$ cells and the seeding volume was varied from $50 \mu \mathrm{L}$ up to $400 \mu \mathrm{L}$ for the different experiments, therewith changing seeding concentration from $1.25 \times 10^{5}$ to $8.3 \times 10^{6}$ cells/ mL. After 1.5 hour of incubation in the given volume, the medium was filled up to $500 \mu \mathrm{L}$ and culture was continued for a total of 24 hours. From these conditions, the influence of three parameters on CSE can be determined.

First of all, the influence of initial cell number is investigated by seeding a range of cell numbers in a specific volume. This is carried out for different volumes, to investigate what is the optimal cell number in a given volume to maximize CSE. Secondly, the influence of initial cell number on CSE will be determined by using a fixed seeding concentration of $2 \times 10^{6}$ cells $/ \mathrm{mL}$. Finally, the influence of seeding volume will be represented for different initial cell numbers.

To assess the influence of well plate adherence on CSE, agarose wells were prepared by casting $3 \%$ agarose (UltraPure, Invitrogen) on a mold with a cylindrical pillar with a diameter of $8 \mathrm{~mm}$ and a height of $3 \mathrm{~mm}$ in a 6 -well plate (Figure 3.1). After the 

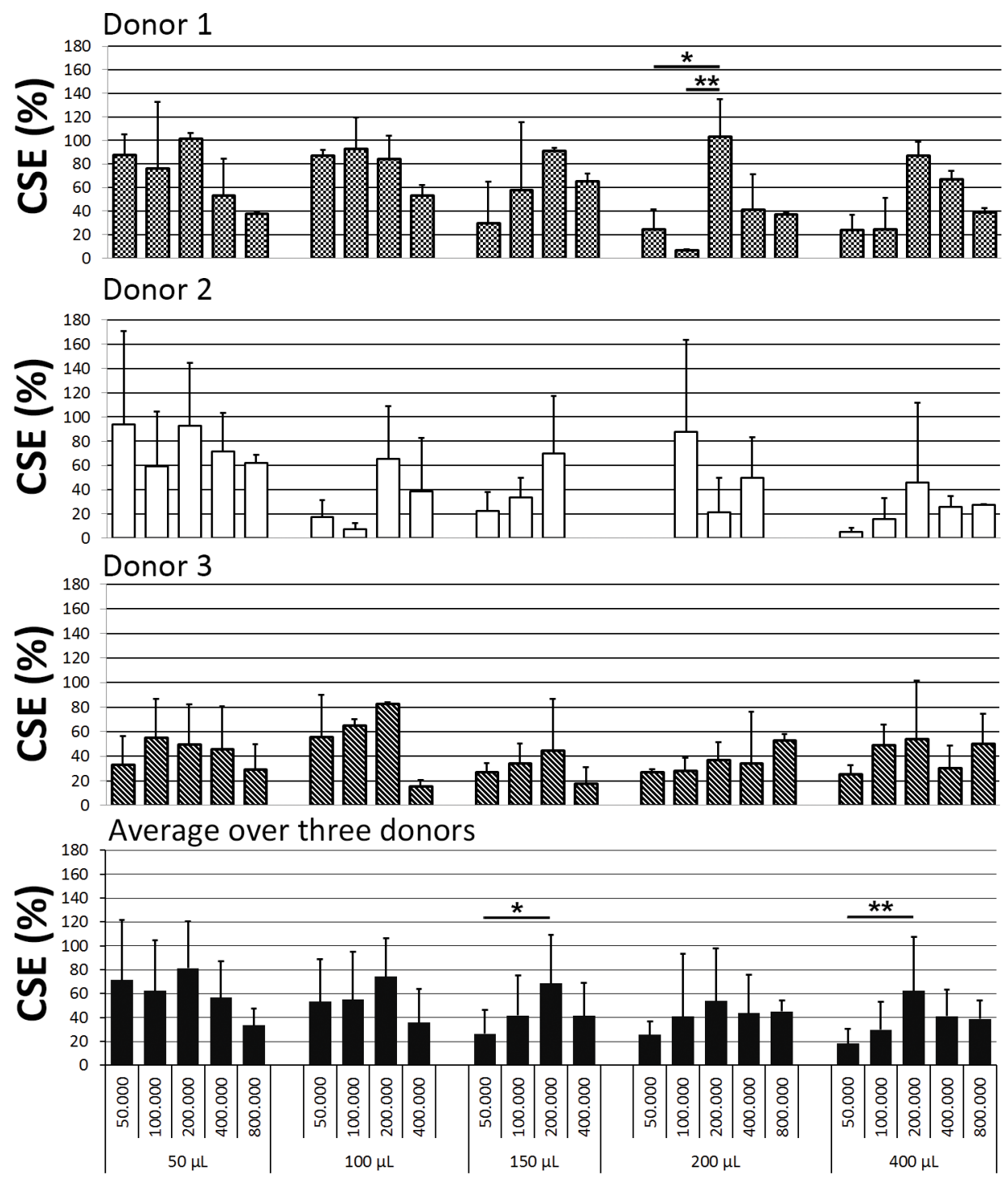

Figure 3.2: Percentage of initial cell number adhered after 24 hours The labels on the $\mathrm{x}$-axis correspond to the initial cell numbers and the cell seeding volumes used in the first 1.5 hour of culture. The initial seeding of $2 \times 10^{5}$ cells/scaffold shows the highest seeding efficiency. In absolute numbers, the higher initial cell numbers show also a higher amount of adhered cells. However, the loss of non-adhered cells also increases. The lowest initial cell number show lower efficiencies when the seeding volume is increased. ( $\mathrm{n}=3$ per donor. Error bar represents standard deviation. Statistical analysis on the average of three donors with $*=\mathrm{p}<0.05, * *=\mathrm{p}<0.01)$ 
agarose gel was solidified for $30 \mathrm{~min}$ at $5{ }^{\circ} \mathrm{C}$, the mold was carefully removed from the gel, and a cylinder with an $8 \mathrm{~mm}$-well in the middle was punched out of the gel and transferred to a 12-well plate. Scaffolds were placed in the confined agarose well or in a non-treated 12-well plate (negative control). Two hundred thousand $\left(2 \times 10^{5}\right) \mathrm{hMSCs}$ (donor 3, passage 3), were seeded in quintuplicate in $50 \mu \mathrm{L}$ of proliferation medium on top of the scaffolds and resuspended gently to fill all the pores of the scaffold. After 1.5 hour the medium was filled up to $500 \mu \mathrm{L}$ and culture was continued for 24 hours.

As a second group, scaffolds were placed in an agarose coated 96-well plate and on non-tissue culture treated polystyrene (PS) 96-well plate (negative control). Two hundred thousand $\left(2 \times 10^{5}\right)$ hMSCs (donor 2, passage 3 ), were seeded in octuplicate in $50 \mu \mathrm{L}$ of proliferation medium on top of the scaffolds and resuspended gently to fill all the pores of the scaffold. After 1.5 hour the medium was filled up to $500 \mu \mathrm{L}$ and culture was also continued for 24 hours.

As a third group, scaffolds were placed in a 12-well plate and seeded as described for the first group, but in this case in $400 \mu \mathrm{L}$ instead of $50 \mu \mathrm{L}$ of proliferation medium. After 1.5 hour the medium was filled up to $500 \mu \mathrm{L}$ and culture was continued for 24 hours. All the seeded scaffolds from the three groups were placed at $37{ }^{\circ} \mathrm{C}$ in a humidified atmosphere with $5 \% \mathrm{CO}_{2}$ and cultured either on an XY rotating agitation plate $(20 \mathrm{rpm})$ or statically on a shelf in an incubator.

\subsubsection{CSE by DNA assay}

After culture, all scaffolds were washed gently in PBS, dried by aspirating the PBS, cut in pieces and stored at $-80^{\circ} \mathrm{C}$ for at least 24 hours. After thawing, the constructs were digested for 16 hours at $56{ }^{\circ} \mathrm{C}$ with $1 \mathrm{mg} / \mathrm{mL}$ proteinase $\mathrm{K}$ (Sigma-Aldrich) in Tris/EDTA buffer ( $\mathrm{pH} 7.6$ ). This solution contained $18.5 \mu \mathrm{g} / \mathrm{mL}$ iodoacetamine (Sigma Aldrich) and $1 \mu \mathrm{g} / \mathrm{mL}$ Pepstatin A (Sigma Aldrich). Quantification of total DNA was done using the CyQuant ${ }^{\mathrm{TM}} \mathrm{DNA}$ assay (Molecular Probes) and a spectrophotometer (excitation $480 \mathrm{~nm}$, emission $520 \mathrm{~nm}$ ) (Victor 3, Perkin Elmer). CSE is given by $\mathrm{DNA}_{\text {scaffold }} / \mathrm{DNA}_{\text {initial }} \times 100 \%$, where the $\mathrm{DNA}_{\text {initial }}$ is calculated by the initial number of cells seeded $\times 7.7 \mathrm{pg}$ DNA/cell [42].

\subsubsection{Cell loss by DNA assay}

hMSCs (donor 4) were seeded with a concentration of $2 \times 10^{6}$ cells/ mL on standard scaffolds for different initial cell numbers. After 24 hours and after 7 days of culture the media was collected from the wells and stored in $-80^{\circ} \mathrm{C}$ for DNA quantification. The scaffolds were washed gently with PBS, transferred to eppendorf tubes and stored in $-80^{\circ} \mathrm{C}$ for further processing. The well-plate was also stored for DNA analysis. The DNA content in the scaffolds, media and wells was determined as described before. Briefly, the tubes containing the media from the scaffolds were centrifuged at $11,000 \mathrm{~g}$ to pellet the protein content. The supernatant was removed and $125 \mu \mathrm{L}$ of Proteinase $\mathrm{K}$ solution was added to the pellets and to the well-plates to digest the ECM as decribed before. After incubation the lysates of the media samples and the wells were pooled per sample. Quantification of total DNA was done using the CyQuant ${ }^{\mathrm{TM}}$ DNA 
assay (Molecular Probes) and a spectrophotometer (excitation $480 \mathrm{~nm}$, emission 520 nm) (Victor 3, Perkin Elmer).

\subsubsection{Methylene blue staining}

The scaffolds were washed gently with PBS and fixated in 10\% formalin for 30 minutes. Next, the samples were washed with water and stained for 30 seconds using a $1 \%$ methylene blue solution in $0.1 \mathrm{M}$ borax buffer $(\mathrm{pH}=8.5)$. Scaffolds were subsequently washed with demineralized (DI) water until the water was clear. The scaffolds were imaged with a Nikon SMZ800 Stereomicroscope equipped with a QImaginge Retiga 1300 camera.

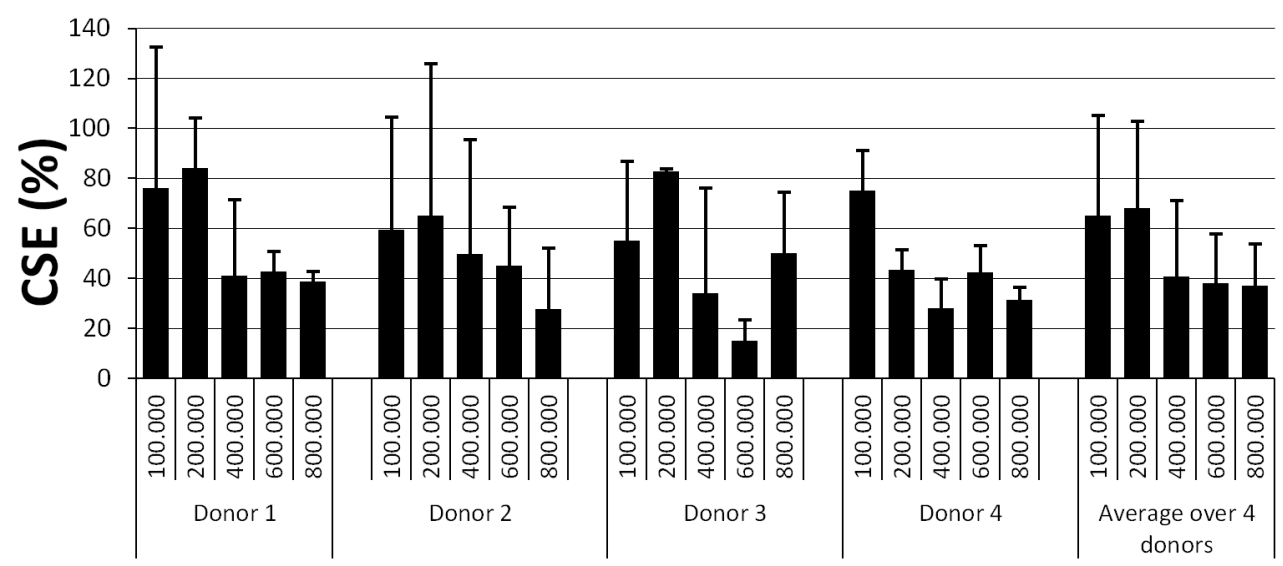

Figure 3.3: High CSE is achieved for 200.000 cells when the concentration of the cell suspension is $2 \times 10^{6}$ cells $/ \mathrm{mL}$ for the different cell numbers. At higher cell numbers the CSE decreased. ( $\mathrm{n}=6$ for donor 2. $\mathrm{n}=3$ for other donors. Error bar represents the standard deviation)

\subsubsection{Scanning Electron Microscopy}

The scaffolds were dehydrated after methylene blue staining by the use of an ethanol gradient series of $60 \%, 70 \%, 80 \%, 90 \%, 96 \%$ and $100 \% \mathrm{v} / \mathrm{v}$ ethanol in DI-water. The scaffolds were further processed by critical point drying from liquid carbon dioxide using a Balzers CPD 030 critical point dryer. The dried samples were gold sputter coated (Cressington) and imaged with scanning electron microscopy (SEM) with a Philips XL 30 ESEM-FEG.

\subsubsection{Statistical analysis}

CSE data was compared by one-way ANOVA followed by a Tukeys post hoc test, and $\mathrm{p}<0.05$ considered statistically significant. All data were expressed as mean with standard deviation as error bar. Data were compared between volumes with equal cell number, between cell numbers with equal volume and between various cell 
numbers with a constant seeding density for four donors in triplicate or sextuplicate. For the seeding method studies, the data from Agarose wells were compared to the data from non-treated PS wells and dynamic seeding was compared to static seeding for two donors in quintuplicate and octuplicate respectively.

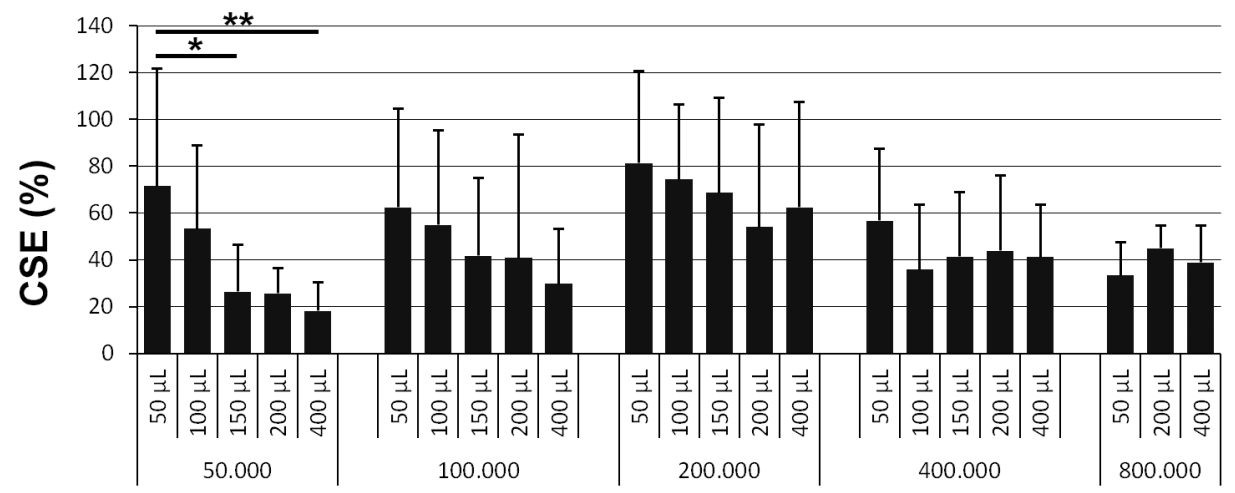

Figure 3.4: Influence of initial seeding volume on the seeding efficiency per cell number. As it can be seen, there is a significance influence of the seeding volume in the first 1.5 hour at low initial cell numbers. For high cell numbers it was observed that when seeding in only $50 \mu \mathrm{L}$ the cell suspension tends to dry out. (Average of three donors, $\mathrm{n}=9,{ }^{*}=\mathrm{p}<0.05$, $* *=\mathrm{p}<0.01)$

\subsection{Results}

\subsubsection{CSE versus initial cell number per seeding volume}

Figure 3.2 shows the results of CSE, from three hMSCs donors separately and as an average. The initial seeding of $2 \times 10^{5}$ cells per scaffold showed the highest efficiency in all volumes. The absolute number of adhered cells increased with increasing the initial number of cells. However, the loss of non-adhered cells also increased. Therefore, the high initial cell numbers of $4 \times 10^{5}$ and $8 \times 10^{5}$ cells showed a slightly lower CSE than $2 \times 10^{5}$ cells. Lower initial cell number also showed slightly lower efficiencies compared to $2 \times 10^{5}$ cells.

\subsubsection{CSE versus initial cell number in fixed seeding concentration}

As it can be seen in Figure 3.3, the highest CSE for all donors was found when initially $1 \times 10^{5}$ or $2 \times 10^{5}$ cells were seeded. When the initial cell number was increased the CSE decreased, even though the concentration of the cell suspension was retained similar. Donor 3 showed a slight increased seeding efficiency for $8 \times 10^{5}$ cells with respect to $4 \times 10^{5}$ or $6 \times 10^{5}$ cells. Donor 4 , which represents a less heterogeneous cell population than the other three donors, showed similar trends. However, lower variations were found between the replicates. For donor 4 also the number of cells 


\section{CSE per scaffold design}

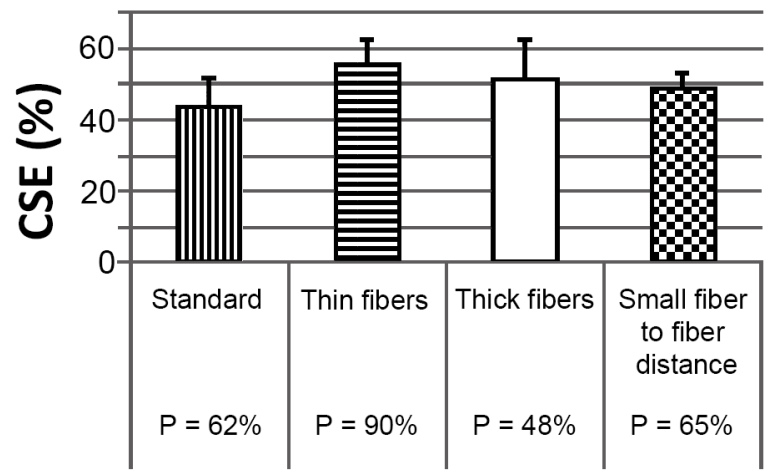

Figure 3.5: Cell seeding efficiency seems not to be dependent on the porosity of the 3D fused deposition modelled scaffolds within the range of scaffold parameters used in this study. $\mathrm{P}$ represents the calculated porosity of the scaffold. Cells were seeded with a density of 200,000 cells in $100 \mu \mathrm{L}$ (donor $4, \mathrm{n}=3$ ).

after 7 days of culture was determined. The number of cells on the scaffold did not change significantly. However, the number of cells detected outside the scaffold by quantification of DNA in the culture medium and the well-plate bottom was higher after 7 days compared to 24 hours (Figure S3.1).

\subsubsection{CSE versus seeding volume per initial cell number}

In Figure 3.4 a change in trends with respect to initial seeded cell number was observed. At low cell number, large volumes showed lower efficiencies. Conversely, at high cell numbers, large volumes showed a slight increase in CSE. At high cell numbers $\left(4 \times 10^{5}\right.$ and $8 \times 10^{5}$ cells $)$ seeded in $50 \mu \mathrm{L}$, cell suspension nearly dried out after 1.5 hour of incubation. Changes in CSE were in most conditions not significant due to the high donor-to-donor experimental variability.

\subsubsection{CSE on scaffolds with various designs}

Figure 3.5 shows the DNA quantification results of hMSCs on scaffolds with different designs. All scaffolds had the same outer dimensions but were altered with respect to fiber thickness or fiber to fiber distance resulting in changing porosities and pore sizes. Standard scaffolds were composed with a fiber diameter $\left(\mathrm{d}_{1}\right)$ of $248 \pm 12.8 \mu \mathrm{m}$, a fiber to fiber distance $\left(\mathrm{d}_{2}\right)$ of $800 \pm 11.8 \mu \mathrm{m}$ and a layer thickness of $159 \pm 35.3 \mu \mathrm{m}$ $\left(\mathrm{d}_{3}\right)$ resulting in a porosity of $62 \%$. Scaffolds with 'thin' fibers were composed with $\mathrm{a} \mathrm{d}_{1}$ of $127 \pm 65.9 \mu \mathrm{m}, \mathrm{a} \mathrm{d}_{2}$ of $800 \pm 14.3 \mu \mathrm{m}$ and $\mathrm{a} \mathrm{d}_{3}$ of $154.2 \pm 27.9 \mu \mathrm{m}$ resulting in a porosity of $90 \%$. Scaffolds with 'thick' fibers were composed with a $\mathrm{d}_{1}$ of $285 \pm$ $21.8 \mu \mathrm{m}, \mathrm{a} \mathrm{d}_{2}$ of $800 \pm 25 \mu \mathrm{m}$ and $\mathrm{a} \mathrm{d}_{3}$ of $151.8 \pm 24.2 \mu \mathrm{m}$ resulting in a porosity of $48 \%$. Scaffolds with a smaller $\mathrm{d}_{2}$ of $650 \pm 12 \mu \mathrm{m}$, showed a $\mathrm{d}_{1}$ of $207.7 \pm 16.6 \mu \mathrm{m}$ 


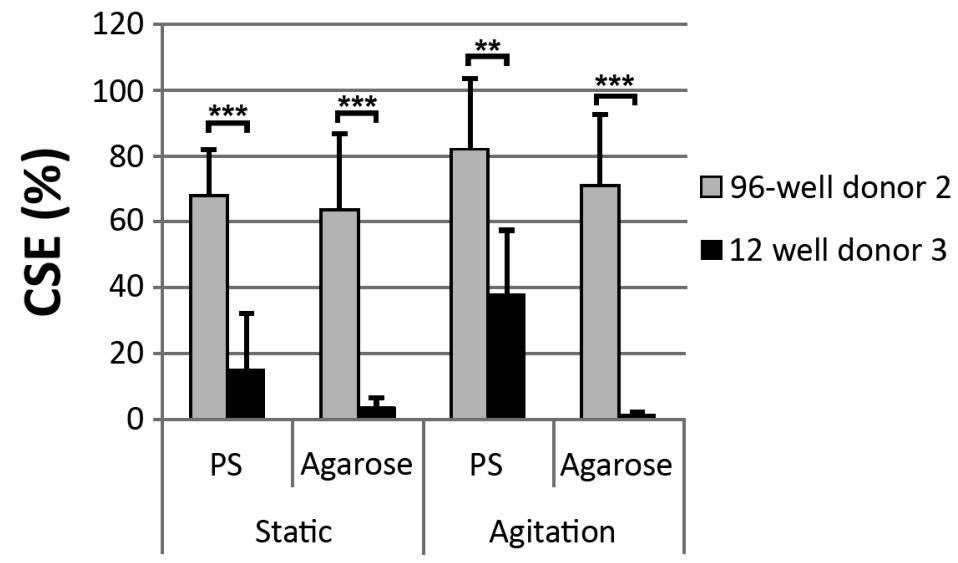

Figure 3.6: Influence of agitation and confinement of the cell suspension. When the scaffolds are seeded with $2 \times 10^{5}$ hMSCs in a more confined environment like in a in Agarose molded well this does not necessarily result in higher seeding efficiencies. In contrast there is a drop in cell number. From light microscopy, it was observed that the cells on agarose formed aggregates. It was also observed that the hydrophilicity of the gel allows the cell suspension to spread over the surface of the well outside the scaffold. $(\mathrm{n}=8$ donor $2, \mathrm{n}=5$ donor $\left.3,{ }^{*}=\mathrm{p}<0.05,{ }^{* *}=\mathrm{p}<0.01,{ }^{* * *}=\mathrm{p}<0.001\right)$.

and $\mathrm{a} \mathrm{d}_{3}$ of $148.5 \pm 17.9 \mu \mathrm{m}$ resulting in a porosity of $65 \%$. The scaffolds were seeded with $2 \times 10^{5}$ hMSCs from donor 4 in $100 \mu \mathrm{L}$ of medium. No differences were found in CSE within this range of fiber and pore dimensions.

\subsubsection{CSE in static versus agitation with scaffolds on PS plate or in an agarose well}

As can be seen from DNA analysis shown in Figure 3.6, a significant increase was found in CSE when cells were seeded on scaffolds placed in a smaller more confined 96-well plate well when comparing to a 12 -well plate well. There were no significant differences between the different conditions seeded in a 96-well plate. However, seeding cells on a scaffold placed in agarose wells (12-well plate) significantly decreased CSE with respect to seeding on scaffolds placed on non-tissue culture treated PS. Agitation of seeded scaffolds placed on a PS 12-well plate resulted in increased CSE compared to seeded scaffolds placed on a PS 12-well plate in static culture. Again, in the case of using the smaller and more confined 96 -well plate this increase was not so apparent. An effect of seeding volume was found upon agitation when $2 \times 10^{5}$ cells were seeded in $400 \mu \mathrm{L}$ (Figure S3.2). In the case of static culture on PS no difference in CSE was found between seeding in $50 \mu \mathrm{L}$ or in $400 \mu \mathrm{L}$, which was already shown in Figure 3.4. However, when agitation was applied a small increase in CSE was found in $50 \mu \mathrm{L}$, whereas a small decrease was observed for $400 \mu \mathrm{L}$. 


\subsubsection{Cell adherence and morphology characterization}

Figure 3.7 shows bright field microscopy images of scaffolds seeded with 100,000, 400,000 and 800,000 cells in a fixed concentration of $2 \times 10^{6}$ cells $/ \mathrm{mL}$. The cells resided in the longitudinal pores of the scaffold and tended to form aggregates in the pore volume. SEM and methylene blue staining results for the same conditions confirmed a spread cell morphology for those cells adhered on the fibers of the scaffolds and the formation of cell aggregates across the pores (Figure S3.3).
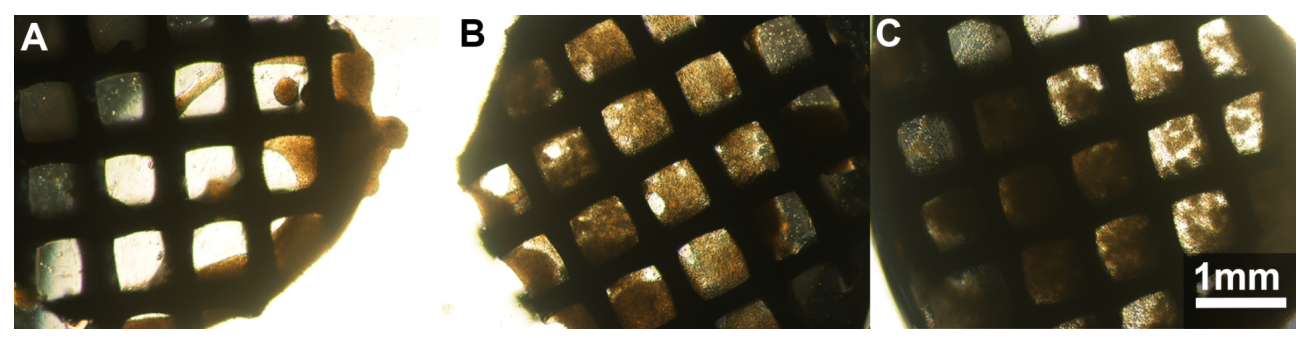

Figure 3.7: Bright Field microscopy images of $100,000,400,000$ and 800,000 hMSCs (donor 2 ) in a fixed concentration of $2 \times 10^{6}$ cells $/ \mathrm{mL}$ after 24 hours of culture. Cells aggregate in the pores or form layers at the bottom of the scaffold.

\subsection{Discussion}

The use of multipotent cell types from autologous source, such as hMSCs, is opted to be promising in tissue engineering approaches. A challenge to overcome is that the availability of autologous donor cells and their expansion capacity without losing functionality is limited [26]. Although several studies on CSE have already been reported before, there are no studies that assess the influence of the seeding parameters reported here on CSE when combining hMSCs and 3D fused deposition modeled polymeric scaffolds for tissue engineering approaches.

In a study reported earlier [43], no influence of the initial cell number on CSE was found when comparing a seeding density of $6 \times 10^{5}$ cells with $1.2 \times 10^{7}$ cells for both human periosteum derived cells (hPDC) and a human osteosarcoma cell line (SaOS-2) on $3 \mathrm{D}$ fused deposition modeled titanium (Ti) scaffolds. In contrast to those results, our study shows that in the case of human MSCs there are differences in CSE when varying the initial cell number. Although in the study of Chen [43] human donor derived cells were used, these cells were already differentiated and therefore possibly possessed different cell adherence properties. Moreover, cell adherence is known to be remarkably different in different biomaterials, thus limiting the comparative analysis between Ti and PEOT/PBT scaffolds. In the case of human MSCs, donor variability can be caused by heterogeneity of the cell population and can result in both differences in cell adherence as well as in cell functionality. Furthermore, the number of human MSCs that can be isolated from a bone marrow aspirate is limited. Therefore it is of clinical importance and relevance to optimize the CSE to obtain sufficient numbers 
of cells in the scaffolds to be able to study cell functionality and to use the gained knowledge to further improve stem cell based regenerative medicine therapies.

In our study, the highest efficiency was found with an initial cell number of $2 \times 10^{5}$ cells for all seeding volumes analyzed (Figure 3.2). A similar trend was found in the study of Alvarez-Barreto et al. [28] where the seeding of a low number of MC3T3-E1 cells $\left(2.5 \times 10^{5}\right.$ cells $)$ showed a higher CSE than the seeding of a high number of cells $\left(5 \times 10^{5}\right.$ and $1 \times 10^{6}$ cells $)$. This was shown for two scaffold architectures, fibrous meshes and porous foams, with similar outer dimensions and porosity but different pore shapes and sizes. The lower CSE measured for high initial cell numbers when compared to $2 \times 10^{5}$ cells, in the study reported here, could be caused by aggregation of the cells which is observed by microscopy (Figure 3.7 and Figure S3.1) and reported before [32]. These non-adhered aggregates could have been lost during the washing step with PBS. Alternatively, a limited availability of scaffold surface area could result in a decrease in CSE because of reaching a plateau in absolute cell number when reaching near-confluence [44]. The low CSE observed with low initial cell numbers could be explained by the low density of the cells in the suspension jeopardizing cellcell contact. Recent studies reported on a possible effect of macromolecular crowding on cell culture. Here, cell culture is mentioned as a typical example, where cells anchored to a culture plate find themselves bathed in an ocean of medium that is hardly representative of their in vivo microenvironment [45]. It can also be observed that some conditions showed high variation between the replicates. Seeding the cells for our experiments was carried out by one experimenter excluding changing results due to handling. We think the high deviations could be caused by donor-to-donor variance which may be resulted from the heterogeneity of each cell population during isolation. Therefore, also cells from a fourth donor, which are colony-picked and known to represent a more homogeneous population, were included in this study. Indeed, for this more homogenous hMSCs population, lower variations were observed between replicates.

To investigate whether the density of the cells or only the absolute cell number of cells has an influence on CSE, the concentration of the cell suspension was kept constant (Figure 3.3). In this way, the nutrient availability per cell and cell to cell distance was also constant. As can be seen in figure 3.3, the highest CSE was found when initially $1 \times 10^{5}$ or $2 \times 10^{5}$ cells were seeded for all donors. When the initial cell number was increased, the CSE decreased. This could still be caused by the formation of cell aggregates as mentioned before or by the limited scaffold surface available with respect to the number of seeded cells, leading to a decreased probability that one cell finds unoccupied scaffold surface to adhere to. An explanation for the decrease in CSE when increasing the cell number can be that the seeding volume for this high initial cell number was larger than for the lower cell numbers, which results in a fraction of the cell suspension flowing outside the scaffold. For one out of the four donors analyzed, an increase in CSE was found when $8 \times 10^{5}$ cells were seeded compared to $6 \times 10^{5}$ cells. This singular case could be explained by the fact that some of the aggregates that were formed stayed entrapped within the scaffold. Chen et al. reported also a negative influence of larger seeding volume on CSE [43]. However, this was only reported for a low cell number (60,000 cells). When comparing the results on cell number in the scaffolds after 1 and 7 days it can be seen that the number of cells 
did not increase significantly (Figure S3.3). The number of cells outside the scaffolds showed an increase after 7 days of culture. This could be caused by part of the cells populating the pores without firmly attaching to the scaffolds. Since the material has shown good biocompatibility before, there was no severe cell death expected. The difference between total detected number of cells in the scaffold, medium and well plate together compared to the initial seeded cell number could be caused by cell loss during processing for analysis. A number of cells could have been entrapped within the scaffold but without adhering to the scaffold within 24 hours. After washing the scaffolds with PBS, these cells could have been partly lost.

In figure 3.4, a change in trends can be observed, where at low cell number low seeding volumes showed the highest efficiencies, whereas at high cell numbers higher seeding volumes did not affect CSE. By bright field microscopy it was observed that high initial cell numbers in $50 \mu \mathrm{L}$ nearly dried out within the 1.5 hour of incubation. Although this drying of the cell suspension could lead to an increase in cell death, it does not seem to explain the low CSE for these high cell numbers, since at higher seeding volumes similar low cell numbers were detected after 24 hours of culture. This shows that the optimal cell seeding volume is not only related to the pore volume and surface area of the scaffold, but is also dependent on the initial number of cells seeded.

To test if the porosity of the scaffold influences the number of adhered cells, three other scaffold designs were introduced with changing fiber dimensions and fiber to fiber distance, resulting in various porosities ranging from 48 till $90 \%$. There was no influence found on CSE within these range of variations in scaffold design. Despite we cannot exclude that significant differences could have been found with scaffold designs with larger variations, we focused our efforts in this study to examine optimal CSE conditions for scaffolds with porosities and pore size that already showed to be promising for musculoskeletal tissue engineering applications [46-48].

Another method that could improve CSE is by placing the scaffolds in a confined environment. Agarose wells have shown to be useful to culture cells within a defined area and to prevent the cells from adhering to the bottom of a culture plate [49]. To improve the homogeneity of the cellular distribution throughout the construct and therewith the CSE, gentle agitation could be applied. To test if the use of these two methods results in higher seeding efficiencies within the scaffolds, $2 \times 10^{5}$ cells were seeded in 50 or $400 \mu \mathrm{L}$ on scaffolds with the same culture parameters as the standard scaffold in the previous experiments. Two different sized culture wells were used. DNA quantification (Figure 3.6) showed that the use of agarose as a non-adherent layer did not significantly improve CSE for both a small well from a 96-well plate coated with agarose as well as for a confined molded agarose well placed in a 12well plate. In the 12-well plate the use of an agarose well even seemed to decrease the CSE. From light microscopy, it could be seen that the cells in the agarose well started to aggregate resulting in non-adhered cell clumps outside the scaffold. It was observed that directly upon seeding, the cell suspension easily flowed outside the scaffold and spread on the agarose gel completely covering the bottom of the agarose well. This agarose well had a diameter of $8 \mathrm{~mm}$, whereas the scaffold was only $4 \mathrm{~mm}$ in diameter, resulting in some cell aggregates being separate from the scaffold. This spreading behavior of the cell suspension could be caused by the high hydrophilicity of the agarose well bottom and sidewalls, since this behavior was not observed on 
non-tissue culture treated PS and also not so apparent in an agarose coated well of a 96-well plate. In the case of smaller confined wells, the CSE was significantly higher than for scaffolds placed in a 12-well plate. Although the two experiments with different well-plates were carried out for different donors, donor 3 showed higher CSEs than donor 2 in previous experiments. Therefore, it is fair to conclude that seeding scaffolds in small confined wells improves the CSE.

To improve both cell distribution and CSE, scaffolds were placed on an $\mathrm{x}-\mathrm{y}-$ agitation plate. A difference in the effect of agitation on CSE was found when the seeding volume was changed from 50 to $400 \mu \mathrm{L}$ for scaffolds placed in a PS 12-well plate. In the case of $50 \mu \mathrm{L}$ a small increase in CSE was found upon agitation, whereas seeding in $400 \mu \mathrm{L}$ resulted in a decrease in CSE upon agitation. This could be caused by the fact that $400 \mu \mathrm{L}$ was a too high volume to fit into the pores of the scaffold. Due to agitation cells could be promoted to flow outside the scaffold. When seeded in only $50 \mu \mathrm{L}$, the cell suspension resided within the pores of the scaffold during agitation.

Previous works showed the beneficial effect of perfusion or convection flow on cell attachment and distribution [28]. In our study, the culture plate was only agitated in the $\mathrm{x}-\mathrm{y}$ plane, which was causing less convection throughout the scaffold than for example in a spinner flask or a perfusion bioreactor. We observed that cells seeded on PS 12-well plates without scaffolds formed aggregates in the center of the well when $\mathrm{x}$-y-agitation was applied. The adherence to the PS showed to be lower upon agitation than when cells were cultured statically. It can very well be that in the experiment with the scaffolds placed in a 12-well plate, on both PS and on agarose, lower cell numbers were found because of this cell aggregation. Aggregates have shown to better retain multipotency when culturing hMCSs [50], however in this study the aggregates can have been lost upon sample processing, due to low-adherence to the scaffold (Figure 3.7 and Figure S3.2). Future studies will further investigate the influence of convection or perfusion culture on CSE and cell differentiation. In summary, we showed in this study that the optimal seeding volume is dependent on the initial cell number seeded. In absolute cell numbers, a higher initial seeded number of cells $(>2$ $\times 10^{5}$ cells) resulted in most cases in a higher number of cells adhered to the scaffold. However, a low number of cells $\left(1 \times 10^{5}\right.$ and $\left.2 \times 10^{5}\right)$ generally resulted in a higher CSE.

\subsection{Conclusion}

Seeding cells into a scaffold is a critical step in a tissue engineering process. Here, optimizing seeding parameters have shown to be valuable to reduce cell losses. Initial cell numbers, seeding concentration, seeding volume and seeding condition were varied over a broad range. CSE decreased for the highest initial cell number due to aggregation, while the lowest initial cell number also showed a decrease in CSE possibly due to limited cell-cell contact. The influence of seeding volume is highly dependent on the initial cell number used. In the case of seeding $5 \times 10^{4}$ cells, a small seeding volume of $50 \mu \mathrm{l}$ shows a significant better CSE than seeding in 150 or 400 $\mu \mathrm{l}$. For higher cell numbers this effect of seeding volume on CSE was not apparent. When the concentration of the cell suspension is constant, the available pore volume of the scaffold will also influence the CSE. There was no difference found in CSE for 
different scaffold designs with changing porosities or pore sizes, which resulted in pore volumes only ranging from 18 till $34 \mu \mathrm{l}$. However, when seeding volumes are greater than the available pore volume, the cell suspension will flow partly outside the scaffold, therewith resulting in a higher cell loss. Agitation upon seeding did not improve CSE when using human MSCs on this type of scaffolds. Yet a significant increase in CSE was found both upon static and agitation seeding when scaffolds were place in a more confined smaller well of a 96 -well plate compared to scaffolds placed in a 12-well plate. Overall, it can be concluded that by optimizing the seeding parameters for each specific culture system, a more efficient use of donor cells is achieved.

\section{Acknowledgements}

The authors gratefully acknowledge the funding from the Netherlands Institute for Regenerative Medicine (NIRM) through the grant number FES0908. Some of the materials employed in this work were provided by the Texas A\&M Health Science Center College of Medicine Institute for Regenerative Medicine at Scott \& White through a grant from NCRR of the NIH (Grant \# P40RR017447). 


\section{References}

[1] Langer R, Vacanti JP. Tissue engineering. Science. 1993;260:920-6.

[2] Woodfield TBF, Malda J, de Wijn J, Peters F, Riesle J, van Blitterswijk CA. Design of porous scaffolds for cartilage tissue engineering using a three-dimensional fiber-deposition technique. Biomaterials. 2004;25:4149-61.

[3] Woodfield TBF, Moroni L, Malda J. Combinatorial Approaches to Controlling Cell Behaviour and Tissue Formation in 3D via Rapid-Prototyping and Smart Scaffold Design. Combinatorial Chemistry \& High Throughput Screening. 2009;12:562-79.

[4] Malda J, Woodfield TBF, van der Vloodt F, Wilson C, Martens DE, Tramper J, et al. The effect of PEGT/PBT scaffold architecture on the composition of tissue engineered cartilage. Biomaterials. 2005;26:63-72.

[5] Moroni L, de Wijn JR, van Blitterswijk CA. 3D fiber-deposited scaffolds for tissue engineering: Influence of pores geometry and architecture on dynamic mechanical properties. Biomaterials. 2006;27:974-85.

[6] Beumer GJ, van Blitterswijk CA, Ponec M. Biocompatibility of a biodegradable matrix used as a skin substitute: an in vivo evaluation. J Biomed Mater Res. 1994;28:545-52.

[7] Bakker D, van Blitterswijk CA, Hesseling SC, Grote JJ. Effect of implantation site on phagocyte/polymer interaction and fibrous capsule formation. Biomaterials. 1988;9:14-23.

[8] Beumer GJ, van Blitterswijk CA, Ponec M. Degradative behaviour of polymeric matrices in (sub)dermal and muscle tissue of the rat: a quantitative study. Biomaterials. 1994;15:551-9.

[9] Mensik I, Lamme EN, Riesle J, Brychta P. Effectiveness and Safety of the PEGT/PBT Copolymer Scaffold as Dermal Substitute in Scar Reconstruction Wounds (Feasibility Trial). Cell Tissue Bank. 2002;3:245-53.

[10] Meijer GJ, van Dooren A, Gaillard ML, Dalmeijer R, de Putter C, Koole R, et al. Polyactive as a bone-filler in a beagle dog model. International journal of oral and maxillofacial surgery. 1996;25:210-16.

[11] Du C, Meijer GJ, van de Valk C, Haan RE, Bezemer JM, Hesseling SC, et al. Bone growth in biomimetic apatite coated porous Polyactive $((\mathrm{R}))$ 1000PEGT70PBT30 implants. Biomaterials. 2002;23:4649-56.

[12] Moroni L, Hendriks JA, Schotel R, de Wijn JR, van Blitterswijk CA. Design of biphasic polymeric 3-dimensional fiber deposited scaffolds for cartilage tissue engineering applications. Tissue Eng. 2007;13:361-71.

[13] Jansen EJ, Pieper J, Gijbels MJ, Guldemond NA, Riesle J, Van Rhijn LW, et al. PEOT/PBT based scaffolds with low mechanical properties improve cartilage repair tissue formation in osteochondral defects. Journal of biomedical materials research. 2009;89:444-52.

[14] Nandakumar A, Cruz C, Mentink A, Birgani ZT, Moroni L, van Blitterswijk C, et al. Monolithic and assembled polymer-ceramic composites for bone regeneration. Acta biomaterialia. 2013;9:5708-17.

[15] Mackay AM, Beck SC, Murphy JM, Barry FP, Chichester CO, Pittenger MF. Chondrogenic differentiation of cultured human mesenchymal stem cells from marrow. Tissue Eng. 1998;4:415-28.

[16] Pittenger MF, Mackay AM, Beck SC, Jaiswal RK, Douglas R, Mosca JD, et al. Multilineage potential of adult human mesenchymal stem cells. Science. 1999;284:143-7.

[17] Abrahamsson CK, Yang F, Park H, Brunger JM, Valonen PK, Langer R, et al. Chondrogenesis and mineralization during in vitro culture of human mesenchymal stem cells on three-dimensional woven scaffolds. Tissue engineering. 2010;16:3709-18.

[18] Hu J, Feng K, Liu X, Ma PX. Chondrogenic and osteogenic differentiations of human bone marrow-derived mesenchymal stem cells on a nanofibrous scaffold with designed pore network. Biomaterials. 2009;30:5061-7.

[19] Nguyen LT, Liao S, Chan CK, Ramakrishna S. Enhanced osteogenic differentiation with 3D electrospun nanofibrous scaffolds. Nanomedicine (Lond). 2012;7:1561-1575.

[20] Jaiswal N, Haynesworth SE, Caplan AI, Bruder SP. Osteogenic differentiation of purified, 
culture-expanded human mesenchymal stem cells in vitro. Journal of Cellular Biochemistry. 1997;64:295-312.

[21] Tian H, Bharadwaj S, Liu Y, Ma H, Ma PX, Atala A, et al. Myogenic differentiation of human bone marrow mesenchymal stem cells on a 3D nano fibrous scaffold for bladder tissue engineering. Biomaterials. 2010;31:870-7.

[22] Li WJ, Tuli R, Huang XX, Laquerriere P, Tuan RS. Multilineage differentiation of human mesenchymal stem cells in a three-dimensional nanofibrous scaffold. Biomaterials. 2005;26:5158-66.

[23] Lee HK, Lee BH, Park SA, Kim CW. The proteomic analysis of an adipocyte differentiated from human mesenchymal stem cells using two-dimensional gel electrophoresis. Proteomics. 2006;6:1223-9.

[24] Janeczek Portalska K, Leferink A, Groen N, Fernandes H, Moroni L, van Blitterswijk C, et al. Endothelial differentiation of mesenchymal stromal cells. Plos One. 2012;7:e46842.

[25] Shakhbazau AV, Petyovka NV, Kosmacheva SM, Potapnev MP. Neurogenic induction of human mesenchymal stem cells in fibrin 3D matrix. Bulletin of experimental biology and medicine. 2011;150:547-50.

[26] Sekiya I, Larson BL, Smith JR, Pochampally R, Cui JG, Prockop DJ. Expansion of human adult stem cells from bone marrow stroma: conditions that maximize the yields of early progenitors and evaluate their quality. Stem Cells. 2002;20:530-41.

[27] Schop D, van Dijkhuizen-Radersma R, Borgart E, Janssen FW, Rozemuller H, Prins HJ, et al. Expansion of human mesenchymal stromal cells on microcarriers: growth and metabolism. Journal of tissue engineering and regenerative medicine. 2010;4:131-40.

[28] Alvarez-Barreto JF, Linehan SM, Shambaugh RL, Sikavitsas VI. Flow perfusion improves seeding of tissue engineering scaffolds with different architectures. Ann Biomed Eng. 2007;35:429-42.

[29] Papadimitropoulos A, Riboldi SA, Tonnarelli B, Piccinini E, Woodruff MA, Hutmacher DW, et al. A collagen network phase improves cell seeding of open-pore structure scaffolds under perfusion. Journal of tissue engineering and regenerative medicine. 2011;7:183-91.

[30] Griffon DJ, Abulencia JP, Ragetly GR, Fredericks LP, Chaieb S. A comparative study of seeding techniques and three-dimensional matrices for mesenchymal cell attachment. Journal of tissue engineering and regenerative medicine. 2011;5:169-79.

[31] Solchaga LA, Tognana E, Penick K, Baskaran H, Goldberg VM, Caplan AI, et al. A rapid seeding technique for the assembly of large cell/scaffold composite constructs. Tissue Eng. 2006;12:1851-63.

[32] Grayson WL, Bhumiratana S, Cannizzaro C, Chao PH, Lennon DP, Caplan AI, et al. Effects of initial seeding density and fluid perfusion rate on formation of tissue-engineered bone. Tissue engineering. 2008;14:1809-20.

[33] Wang L, Seshareddy K, Weiss ML, Detamore MS. Effect of initial seeding density on human umbilical cord mesenchymal stromal cells for fibrocartilage tissue engineering. Tissue engineering. 2009;15:1009-17.

[34] Wendt D, Marsano A, Jakob M, Heberer M, Martin I. Oscillating perfusion of cell suspensions through three-dimensional scaffolds enhances cell seeding efficiency and uniformity. Biotechnol Bioeng. 2003;84:205-14.

[35] Reichert JC, Cipitria A, Epari DR, Saifzadeh S, Krishnakanth P, Berner A, et al. A Tissue Engineering Solution for Segmental Defect Regeneration in Load-Bearing Long Bones. Sci Transl Med. 2012;4.

[36] Cipitria A, Lange C, Schell H, Wagermaier W, Reichert JC, Hutmacher DW, et al. Porous scaffold architecture guides tissue formation. Journal of Bone and Mineral Research. 2012;27:1275-88.

[37] de Bruijn JD, van den Brink I, Mendes S, Dekker R, Bovell YP, van Blitterswijk CA. Bone induction by implants coated with cultured osteogenic bone marrow cells. Advances in dental research. 1999;13:74-81.

[38] DiGirolamo CM, Stokes D, Colter D, Phinney DG, Class R, Prockop DJ. Propagation and senescence of human marrow stromal cells in culture: a simple colony-forming assay identifies samples with the greatest potential to propagate and differentiate. Brit J Haematol. 1999;107:275-81. 
[39] Phinney DG, Kopen G, Righter W, Webster S, Tremain N, Prockop DJ. Donor variation in the growth properties and osteogenic potential of human marrow stromal cells. Journal of Cellular Biochemistry. 1999;75:424-36.

[40] Moroni L, de Wijn JR, van Blitterswijk CA. Three-dimensional fiber-deposited PEOT/PBT copolymer scaffolds for tissue engineering: influence of porosity, molecular network mesh size, and swelling in aqueous media on dynamic mechanical properties. Journal of biomedical materials research. 2005;75:957-65.

[41] Landers R, Hubner U, Schmelzeisen R, Mulhaupt R. Rapid prototyping of scaffolds derived from thermoreversible hydrogels and tailored for applications in tissue engineering. Biomaterials. 2002;23:4437-47.

[42] Riesle J, Hollander AP, Langer R, Freed LE, Vunjak-Novakovic G. Collagen in tissue-engineered cartilage: types, structure, and crosslinks. J Cell Biochem. 1998;71:313-27.

[43] Chen YT, Bloemen V, Impens S, Moesen M, Luyten FP, Schrooten J. Characterization and Optimization of Cell Seeding in Scaffolds by Factorial Design: Quality by Design Approach for Skeletal Tissue Engineering. Tissue Eng Part C-Me. 2011;17:1211-21.

[44] Holy CE, Shoichet MS, Davies JE. Engineering three-dimensional bone tissue in vitro using biodegradable scaffolds: investigating initial cell-seeding density and culture period. J Biomed Mater Res. 2000;51:376-82.

[45] Chen C, Loe F, Blocki A, Peng Y, Raghunath M. Applying macromolecular crowding to enhance extracellular matrix deposition and its remodeling in vitro for tissue engineering and cell-based therapies. Adv Drug Deliv Rev. 2011;63:277-90.

[46] Kemppainen JM, Hollister SJ. Differential effects of designed scaffold permeability on chondrogenesis by chondrocytes and bone marrow stromal cells. Biomaterials. 2010;31:279-87.

[47] Sobral JM, Caridade SG, Sousa RA, Mano JF, Reis RL. Three-dimensional plotted scaffolds with controlled pore size gradients: Effect of scaffold geometry on mechanical performance and cell seeding efficiency. Acta biomaterialia. 2011;7:1009-18.

[48] Yilgor P, Sousa RA, Reis RL, Hasirci N, Hasirci V. 3D plotted PCL scaffolds for stem cell based bone tissue engineering. Macromol Symp. 2008;269:92-9.

[49] Rivron NC, Rouwkema J, Truckenmuller R, Karperien M, De Boer J, Van Blitterswijk CA. Tissue assembly and organization: Developmental mechanisms in microfabricated tissues. Biomaterials. 2009;30:4851-8.

[50] Baraniak PR, McDevitt TC. Scaffold-free culture of mesenchymal stem cell spheroids in suspension preserves multilineage potential. Cell Tissue Res. 2012;347:701-11. 


\section{Supplementary Information}

\section{Quantification of non-attached cells by DNA assay.}

hMSCs (donor 4) were seeded with a concentration of $2 \times 10^{6}$ cells $/ \mathrm{mL}$ on standard scaffolds for different initial cell numbers. After 24 hours and after 7 days of culture the media was collected from the wells and stored in $-80{ }^{\circ} \mathrm{C}$ for DNA quantification. The scaffolds were washed gently with PBS and transferred to eppendorf tubes and stored in for further processing. The well-plate was also stored at $-80{ }^{\circ} \mathrm{C}$ for DNA analysis. The DNA content in the scaffolds, media and wells was determined as described before. Briefly, the tubes containing the media from the scaffolds were centrifuged at $11,000 \mathrm{~g}$ to pellet the protein content. The supernatant was removed and $125 \mu \mathrm{L}$ of Proteinase $\mathrm{K}$ solution was added to incubate at $56{ }^{\circ} \mathrm{C}$ for approximately 16 hours. The wells were also incubated with $125 \mu \mathrm{L}$ of Proteinase K solution and after incubation the lysates of the media samples and the wells were pooled per sample. The results are presented in Figure S3.1.

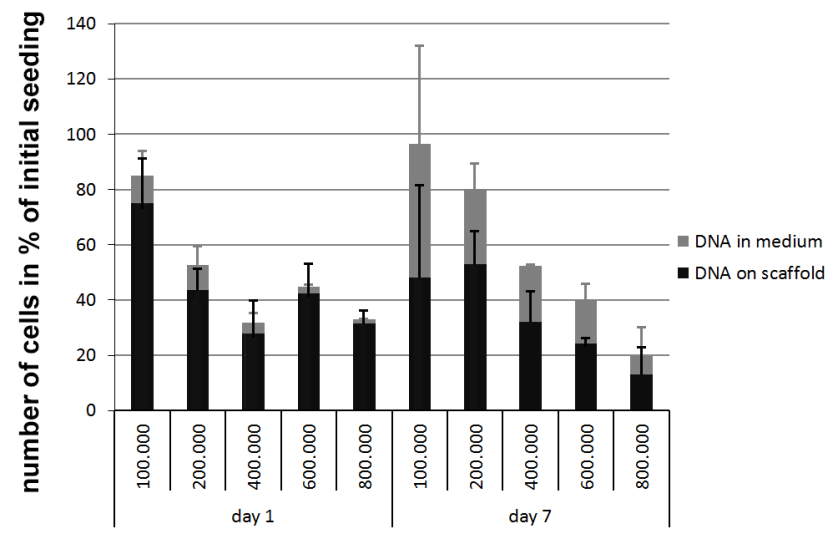

Figure S3.1: DNA quantification on scaffolds and on the culture media and well-plate bottom after 1 day and after 7 days of culture 


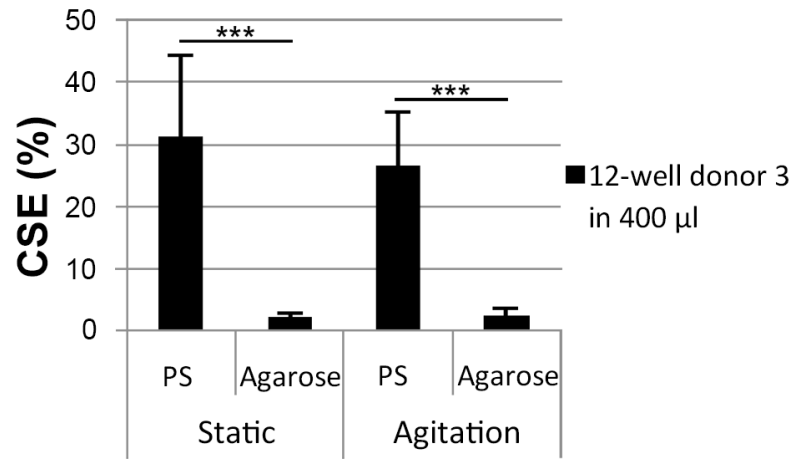

Figure S3.2: The influence of agitation on CSE for scaffolds seeded with 200.000 hMSCs in $400 \mu \mathrm{L}$. A significant decrease in CSE is found when cells are seeded on scaffolds placed in agarose wells. There was no difference found in CSE when agitation was applied during 24 hours of cell culture $\left(\mathrm{n}=5,{ }^{*}=\mathrm{p}<0.05,{ }^{* *}=\mathrm{p}<0.01,{ }^{* * *}=\mathrm{p}<0.001\right)$.
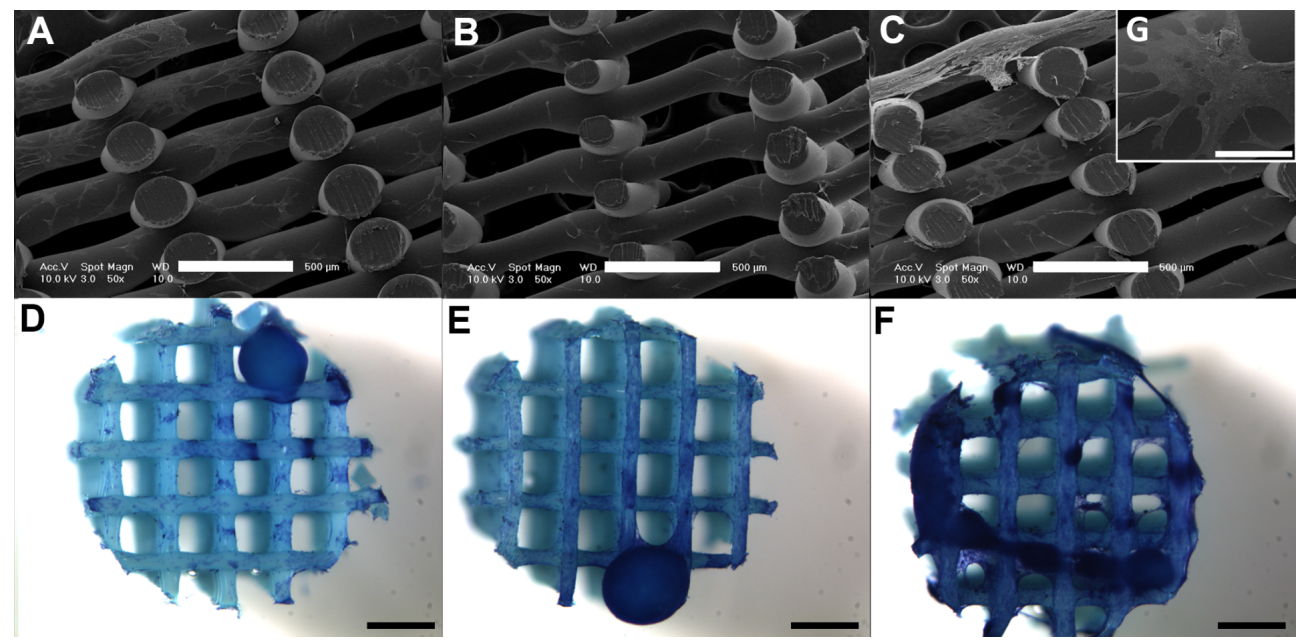

Figure S3.3: Scanning Electron Microscopy and Stereo Microscopy on Fixated and stained samples. (A and D) 100.000 cells in $50 \mu \mathrm{L}$, (B and E) 400.000 cells in $200 \mu \mathrm{L}$ (C and F) 800.000 cells in $400 \mu \mathrm{L}$ for donor 4 after seven days of culture.(G) magnified view of cell morphology of $200.000 \mathrm{hMSCs}$ in $100 \mu \mathrm{L}$ after seven days of culture. All other cell seeding volumes showed similar cell morphology. Scale bars A-C: $500 \mu \mathrm{m}, \mathrm{D}-\mathrm{F}: 1 \mathrm{~mm}, \mathrm{G}: 100 \mu \mathrm{m}$. 


\title{
Chapter 4
}

\section{A comparative study on cell distribution and viability of fetal and adult human bone marrow stromal cells in a biaxial rotating vessel bioreactor after seeding on polymeric $3 \mathrm{D}$ rapid prototyped scaffolds}

\begin{abstract}
A. M. Leferink ${ }^{1}$, Y. Chng ${ }^{2}$, C. A. van Blitterswijk ${ }^{1,3}$, L. Moroni ${ }^{1,3}$
${ }^{1}$ Department of Tissue Regeneration, MIRA - Institute for Biomedical Technology and Technical Medicine, University of Twente, Enschede, The Netherlands, ${ }^{2}$ Quintech Life Sciences Pte Ltd, Singapore, ${ }^{3}$ Department of Complex Tissue Regeneration, Faculty of Health, Medicine and Life Sciences, Maastricht University, Maastricht, The Netherlands
\end{abstract}




\begin{abstract}
One of the conventional approaches in tissue engineering is the use of scaffolds in combination with cells to obtain mechanically stable tissue constructs in vitro prior to implantation. Rapid prototyping by fused deposition modeling is a widely used technique to produce porous scaffolds with defined pore network, geometry, and therewith defined mechanical properties. Bone marrow derived mesenchymal stromal cells (MSCs) are promising candidates for tissue engineering based cell therapies due to their multipotent character. One of the hurdles to overcome when combining rapid prototyped scaffolds with MSCs is the resulting heterogeneous cell distribution and limited cell proliferation capacity. In this study, we show that the use of a biaxial bioreactor, after static culture of human fetal MSCs (hfMSCs) seeded on synthetic polymeric scaffolds, improved the homogeneity of the cell and extracellular matrix (ECM) distribution as well as increased the total cell number. Furthermore, we show that the relative mRNA expression levels of indicators for stemness and differentiation are not significantly changed upon bioreactor culture, whereas static culture shows variations of several indicators for stemness and differentiation. The biaxial rotating bioreactor presented here offers a homogeneous distribution of hfMSCs, enabling studies on MSCs fate in rapid prototyped scaffolds without inducing differentiation by convection flow.
\end{abstract}

Keywords: Bone marrow stromal cells, scaffolds, convection-flow bioreactor, perfusion-flow bioreactor, cellular distribution

Note: All experiments with hfMSCs were carried out in collaboration with Quintech Ltd. in Singapore. The cultured samples were shipped from Singapore for independent analyses at the University of Twente, the Netherlands. All studies with haMSCs were carried out and analyzed at the University of Twente, the Netherlands. 


\subsection{Introduction}

The field of tissue engineering aims at applying the fundamentals of cell biology and materials engineering to construct replacements for damaged, diseased or lost tissue [1]. One of the conventional approaches is based on three-dimensional (3D) mechanically stable scaffolds in combination with multipotent cell types. Scaffolds with a highly defined geometry, porosity and tailored mechanical properties can be obtained by rapid prototyping [2]. These scaffolds provide the necessary support for cells to attach, proliferate and differentiate, and define the overall shape of the tissue engineered transplant. Several researchers already showed successful application of such scaffolds in for example bone and cartilage tissue engineering in vivo [3-5]. Woodfield et al. found a rapid attachment and a homogenous distribution of both bovine and human chondrocytes on poly (ethylene oxide terephthalate)-co-poly (butylene terephthalate) (PEOT/PBT) based scaffolds after spinner flask culture in vitro. Subsequently, the scaffolds seeded with bovine chondrocytes were implanted subcutaneously in mice for 21 days and formed cartilaginous tissue in vivo as demonstrated by the presence of articular ECM components [4].

Reichert et al. have shown the successful application of commercially available rapid prototyped scaffolds of polycaprolactone-tricalciumphosphate (PCL-TCP) combined with recombinant human bone morphogenetic protein 7 (rhBMP-7) in critical sized segmental bone defects in vivo in sheep [3]. However, in the same study, the PCL-TCP scaffolds combined with ovine MSCs showed less bone volume in the defect site 3 months after implantation than the scaffolds combined with rhBMP-7 without MSCs, even though relatively high cell numbers were seeded initially per construct. Therefore, despite successes in regenerating tissues with rapid prototyped scaffolds optionally combined with different bioreactors, the highly organized open structure of rapid prototyped scaffolds still poses challenges in homogenously distributing cells and controlling their proliferation and differentiation capacities. This is even more important when MSCs are used, as their capacity to adhere and be homogeneously distributed in 3D scaffolds has shown to be complicated [6]. Such heterogeneity could ultimately lead to a lack of control of MSCs activity and differentiation.

To gain control over cell seeding efficiency, cell distribution and cell fate on rapid prototyped $3 \mathrm{D}$ scaffolds in vitro prior to implantation or as a study model, several hurdles have to be overcome. Firstly, the cell seeding process has to be optimized per scaffold geometry, scaffold material and cell type to achieve proper cell attachment and distribution throughout the construct [7]. Several studies showed the influence of scaffold geometry or culture conditions in cell and tissue distribution after in vitro culture $[8,9]$. Chen et al. introduced a matrix of hyaluronic acid, methylated collagen and terpolymer in rapid prototyped PCL-scaffolds, which showed to improve the cell seeding efficiency of human MSCs (hMSCs) compared to uncoated PCL scaffolds [10]. In vitro culture of the gel-embedded scaffold in a spinner flask bioreactor significantly improved most of the outcome variables with respect to osteogenic differentiation, such as ALP activity and ECM mineralization, compared to scaffolds in static culture.

Papadimitropoulos et al. also introduced a collagen-network in porous PCL-TCP scaffolds, which resulted in a 2.5 fold increase in MSCs seeding efficiency under perfusion flow compared to the bare PCL-TCP scaffolds [11]. Despite an increased cell 
seeding efficiency in presence of a collagen-network, no obvious qualitative differences were found after 19 days of culture among the experimental groups with respect to cell viability, cell distribution and ECM formation. In contrast to expectations after the in vitro results of Chen et al. [10], this strategy did not lead to robust bone formation in vivo upon ectopic implantation. The absence of bone formation in vivo could, in this study, be caused by the absence of mineralization inducing factors during in vitro culture prior to implantation [11]. Although the incorporation of a collagenous matrix in rapid prototyped scaffolds seemed to have a beneficial effect on cell seeding efficiency, control over cell fate remained elusive.

A second hurdle to overcome is the supply of oxygen and nutrients as well as the clearance of metabolic products which showed to become critically limiting for cells cultured under static conditions [12]. Bioreactor systems, based on convection such as rotating vessels and stirrer flasks, or based on perfusion such as a directional flowthrough bioreactor, are used to overcome these mass transfer limitations [13]. These systems do not only enhance nutrient and waste product exchange but can also exert mechanical stimuli on the cells to proliferate, migrate or differentiate $[13,14]$. While most of these commercially available rotating vessel bioreactors are uniaxial in design, Singh et al. have shown with in silico simulations that a biaxial design, which rotates simultaneously in two independent orthogonal axes, resulted in improved fluidics over an uniaxial design [15].

Here, we investigated the use of a biaxial bioreactor system, further referred to as convection bioreactor, for the in vitro culture of highly porous PEOT/PBT scaffolds seeded with hfMSCs or human adult MSCs (haMSCs). Previous work already showed the superior osteogenic capacity of hfMSCs over haMSCs after comparative studies in vitro in both a monolayer culture system and on a composite bioactive PCL-TCP scaffold in static cultures [16]. In this study, the effect of dynamic culture on cell and ECM distribution as well as on cellular phenotype was assessed for both hfMSCs and haMSCs.

\subsection{Materials and Methods}

\subsubsection{Isolation and culture of hfMSCs and haMSCs}

Bone marrow derived hfMSCs were isolated as described before, from 17 weeks and 1 day old fetuses after clinically indicated termination of pregnancy $[17,18]$. Pregnant women gave separate written consent for the clinical procedure and for the use of fetal tissue for research purposes. Briefly, fetal bone marrow cells were retrieved by flushing the bone marrow cells out of the humeri and femurs into Dulbecco's modified eagle's medium (DMEM, Sigma, USA) with Glutamax (GIBCO, USA) supplemented with $10 \%$ heat-inactivated fetal bovine serum (FBS), $50 \mathrm{U} / \mathrm{mL}$ penicillin, and 50 $\mu \mathrm{g} / \mathrm{mL}$ streptomycin (GIBCO, USA), which will be referred to as fMSC-medium. Medium was refreshed twice per week and cells were used for further subculturing or cryopreservation on reaching near confluence.

Bone marrow derived haMSCs (donor 1 female, 77 years old; donor 2 female, 55 years old) were isolated and proliferated as described previously [19]. Bone marrow aspirates were obtained from patients who had given written informed consent. Briefly, 
aspirates were cultured in minimal essential medium (alpha-MEM, Life Technologies, Gaithersburg, MD) supplemented with $10 \%$ heat-inactivated fetal bovine serum (FBS, Lonza, Switzerland), $0.2 \mathrm{mM}$ L-Ascorbic acid 2-phosphate magnesium salt (ASAP, Sigma Aldrich, the Netherlands), 2 mM L-glutamine (L-glut, Life Technologies), 100 $\mathrm{U} / \mathrm{mL}$ penicillin (Life Technologies), $100 \mu \mathrm{g} / \mathrm{mL}$ streptomycin (Life Technologies) and $1 \mathrm{ng} / \mathrm{mL}$ basic fibroblast growth factor (bFGF, Instruchemie, Delfzijl, The Netherlands), which will be referred to as proliferation medium. Cells were grown at 37 ${ }^{\circ} \mathrm{C}$ in a humidified atmosphere with $5 \% \mathrm{CO}_{2}$. Medium was refreshed twice per week and cells were used for further subculturing or cryopreservation on reaching near confluence.

\subsubsection{Fabrication of PEOT/PBT scaffolds}

Scaffold were fabricated of PolyActive ${ }^{\mathrm{TM}} 300 / 55 / 45$ (PolyVation, Groningen, the Netherlands), a block copolymer composed of poly(ethylene oxide terephthalate) (PEOT) and poly(butylene terephthalate) (PBT) with a weight ratio of 55 to 45 for the two components, respectively, and a molecular weight of the starting poly(ethylene glycol) (PEG)segments of 300 Da used in the co-polymerization process. Fused deposition modeling was used with a bioscaffolder (SysENG, Germany) to fabricate 3D cylindrical scaffolds as described before [2] with a diameter of $8 \mathrm{~mm}$, a height of 3 $\mathrm{mm}$, a fiber to fiber distance of $1000 \mu \mathrm{m}$, a fiber diameter of approximately $200 \mu \mathrm{m}$, and a layer thickness of $150 \mu \mathrm{m}$. To enhance cell attachment scaffolds for studies with hfMSCs were treated in Argon plasma for 30 minutes with a pressure of 0.1-0.2 mBar and a power of $30 \mathrm{~W}$. Sterilization of all scaffolds was performed in $70 \%$ ethanol twice for 30 minutes, subsequently washed in PBS first for 5 minutes and additionally twice for another 30 minutes each time, and finally incubated in culture medium overnight prior to cell culture.

\subsubsection{Cell seeding on PEOT/PBT scaffolds}

For studies with hfMSCs, scaffolds were transferred from tube with culture medium to a non-treated 24-well plate (Greiner Bio-One, Germany). Passage 3 hfMSCs were harvested from monolayer expansion, and seeded on the scaffolds with a density of 750,000 cells in $30 \mu \mathrm{L}$ of fMSC-medium. After 15 minutes of incubation, the scaffolds were flipped and allowed to incubate for another hour, without adding new cell suspension, before $10 \mu \mathrm{L}$ of fMSC-medium was added. Subsequently, for the next 5 hours, $10 \mu \mathrm{L}$ of proliferation medium was added for each seeded scaffolds at an interval of every 1 hour and 15 minutes for each addition. Scaffolds were then transferred to a non-treated 24 -well plate (Greiner) with $750 \mu \mathrm{L}$ of proliferation medium and cultured for 3 days in static culture condition or in a biaxial rotating vessel bioreactor, referred to as convection culture.

For studies with haMSCs, scaffolds were transferred from a tube with culture medium to a non-treated 24-well plate (NUNC, Thermo Scientific, The Netherlands). Passage 3 haMSCs were harvested from monolayer expansion, and seeded on the scaffolds with a density of 750,000 cells in $100 \mu \mathrm{L}$ of proliferation medium. After 1.5 hour incubation to let the cells adhere, the medium was filled up to $1 \mathrm{~mL}$ and culture 
was continued for 3 days in static culture condition before transferring the samples to a new culture well, to the bioreactor convection culture, or to a bioreactor perfusion culture.

\subsubsection{Bioreactor culture}

After static culture, some of the scaffolds were transferred to the convection or perfusion bioreactors, whereas a control group was maintained under static culture conditions. The perfusion bioreactor consisted of a small chamber in which the scaffold was press-fitted to ensure the medium to be flown through the longitudinal pores of the scaffold. The set-up of the bioreactor was constructed as described before [20]. Medium was ran with a flow speed of $0.1 \mathrm{~mL} / \mathrm{min}$ in a home-made incubator at 37 ${ }^{\circ} \mathrm{C}$ with a controlled flow of mixed gas containing $5 \% \mathrm{CO}_{2}$ and $21 \% \mathrm{O}_{2}$. The convection bioreactor consisted of a cylindrical vessel for culture (volume $40 \mathrm{~mL}$ ), in which the cellular-scaffold constructs are mounted to the lid of the bioreactor by pins, and a medium reservoir to ensure continuous replacement of the medium in the culture vessel. Gaseous exchange was enabled through a special membrane incorporated into the spherical vessel. The bioreactor was ran with a medium flow speed of $1 \mathrm{rpm}$ (corresponding to $1.5 \mathrm{~mL} /$ minute), a biaxial rotation with an arm rotational speed of $2 \mathrm{rpm}$, and a chamber rotation speed of $3 \mathrm{rpm}$ at $37^{\circ} \mathrm{C}$ in a humidified atmosphere with $5 \% \mathrm{CO}_{2}$.

Proliferation medium was used to fill the $40 \mathrm{~mL}$ medium reservoir of the perfusion bioreactor containing 1 scaffold seeded with haMSCs per circuitry. Proliferation medium was used to fill the $40 \mathrm{~mL}$ bioreactor chamber and the $300 \mathrm{~mL}$ reservoir of the rotating vessel bioreactor containing 4 scaffolds seeded with haMSCs. fMSCmedium was used to fill the $500 \mathrm{~mL}$ bioreactor chamber and the $300 \mathrm{~mL}$ reservoir of the rotating vessel bioreactor containing 12 scaffolds seeded with hfMSCs. As a negative control, static culture was continued on scaffolds transferred to a new well in a non-treated 24 -well plate.

\subsubsection{Viability staining}

Cell viability was assessed by $4 \mu \mathrm{g} / \mathrm{mL}$ fluorescein diacetate (FDA, Life Technologies) and $40 \mu \mathrm{g} / \mathrm{mL}$ propidium iodide (PI, Life Technologies) staining, where FDA stains viable cells green, and PI stains necrotic and apoptotic cell nuclei red. Scaffolds were cut in half, stained with FDA and PI as previously described [16], and viewed under a confocal laser microscope (Olympus, FV1000 Fluoview, Japan). Cellular scaffolds were examined in both planar view and cross-sectional view after 3 and 9 days of culture (Figure 4A).

\subsubsection{DNA assay}

The total DNA from scaffolds cultured with hfMSCs was extracted from each scaffold by incubating the constructs in $0.4 \mathrm{~mL}$ of enzymatic cocktail (consisting of $0.1 \%$ collagenase A (Roche, Basel, Switzerland) with $0.1 \%$ Trypsin mixed in PBS) at $37{ }^{\circ} \mathrm{C}$ for 2 hours, with vortex every 30 min followed by three cycles of freeze and thaw. For haMSCs, after culture all scaffolds were washed gently in PBS, dried by aspirating 
the PBS, cut in pieces and stored at $-80{ }^{\circ} \mathrm{C}$ for at least 24 hours. After thawing, the constructs were digested for 16 hours at $56{ }^{\circ} \mathrm{C}$ with $1 \mathrm{mg} / \mathrm{mL}$ proteinase $\mathrm{K}$ (SigmaAldrich, the Netherlands) in Tris/EDTA buffer ( $\mathrm{pH}$ 7.6). This solution contained 18.5 $\mu \mathrm{g} / \mathrm{mL}$ iodoacetamine (Sigma Aldrich) and $1 \mu \mathrm{g} / \mathrm{mL}$ Pepstatin A (Sigma Aldrich). Quantification of total DNA was done using the CyQuant@ DNA assay (Molecular Probes, Life Technologies) and a spectrophotometer (excitation $480 \mathrm{~nm}$, emission 520 $\mathrm{nm}$ ) (Victor 3, Perkin Elmer, Groningen, the Netherlands).

\subsubsection{Hydroxyproline assay}

Hydroxyproline assay was carried out to determine the total collagen amount on the same samples as used for DNA quantification. From the digested sample, 30 $\mu \mathrm{L}$ was transferred to a Teflon $\mathbb{R}$ capped glass bottle. Another $30 \mu \mathrm{L}$ of concentrated hydrochloric acid (HCl, 12 M, Sigma Aldrich) was added and samples were hydrolyzed at $120^{\circ} \mathrm{C}$ for 3 hours. The complete supernatant was transferred to a 96 well plate and left to evaporate at $60{ }^{\circ} \mathrm{C}$. Subsequently, $100 \mu \mathrm{L}$ of chloramine T/ Oxidation buffer mix (BioVision, The Netherlands) was added to each well and incubated at room temperature for 5 minutes. Finally, $100 \mu \mathrm{L}$ of DMAB Reagent was added to each well including the hydroxyproline standard and incubated for 90 minutes at 60 ${ }^{\circ} \mathrm{C}$. A micro plate reader (Multiskan GO, Thermo Fisher) was used to determine the absorbance at $560 \mathrm{~nm}$.

\subsubsection{Gene expression analysis of hfMSCs}

For gene expression analysis of hfMSCs, samples were seeded ( $\mathrm{n}=4$ for static cultures; $\mathrm{n}=5$ for convection cultures) at different time points. After culture, medium was aspirated from the scaffolds, the samples were transferred to $2 \mathrm{~mL}$ eppendorf tubes and stored at $-80{ }^{\circ} \mathrm{C}$. Prior to RNA isolation from the samples by using a Bioke RNA II nucleospin RNA isolation kit (Macherey-Nagel, Düren, Germany), first $500 \mu \mathrm{L}$ of TRIzol@ (Invitrogen) was added. The scaffolds were disrupted by crushing with RNA isolation pestles (Fisher Scientific). Samples for basal gene expression analysis, referred to as T25 day 0, were retrieved from two-dimensional (2D) culture in T25 tissue culture flasks (NUNC) by adding $500 \mu \mathrm{L}$ of TRIzol@) (Invitrogen) upon reaching $70 \%$ confluence. Subsequently, the cell/TRIzol@ suspension was transferred to an eppendorf tube and $200 \mu \mathrm{L}$ of $\mathrm{CHCl}_{3}$ was added to each sample and mixed by vigorously shaking the tubes. The TRIzol@ $/ \mathrm{CHCl}_{3}$ mixture was centrifuged at $12,000 \mathrm{~g}$ for 15 minutes at $4{ }^{\circ} \mathrm{C}$. The aqueous phase was transferred to a new eppendorf tube and mixed 1:1 with $70 \%$ ethanol. The mixture was transferred to filter columns from the kit and the RNA isolation was continued following the manufacturer's protocol. RNA concentrations and purity were determined by using an ND1000 spectrophotometer (Nanodrop Technologies, USA). CDNA was synthesized from $630 \mathrm{ng}$ of RNA, using iScript $^{\mathrm{TM}}$ (BIO-RAD, Veenendaal, the Netherlands) according to the manufacturer's protocol.

Quantitative polymerase chain reaction ( $\mathrm{qPCR}$ ) was performed on $\mathrm{cDNA}$ samples by using the iQ SYBR@Green Supermix (Bio-Rad) on the primers as listed in Table S4.1. PCR reactions were carried out on the MyiQ2 Two-Color Real-Time PCR 

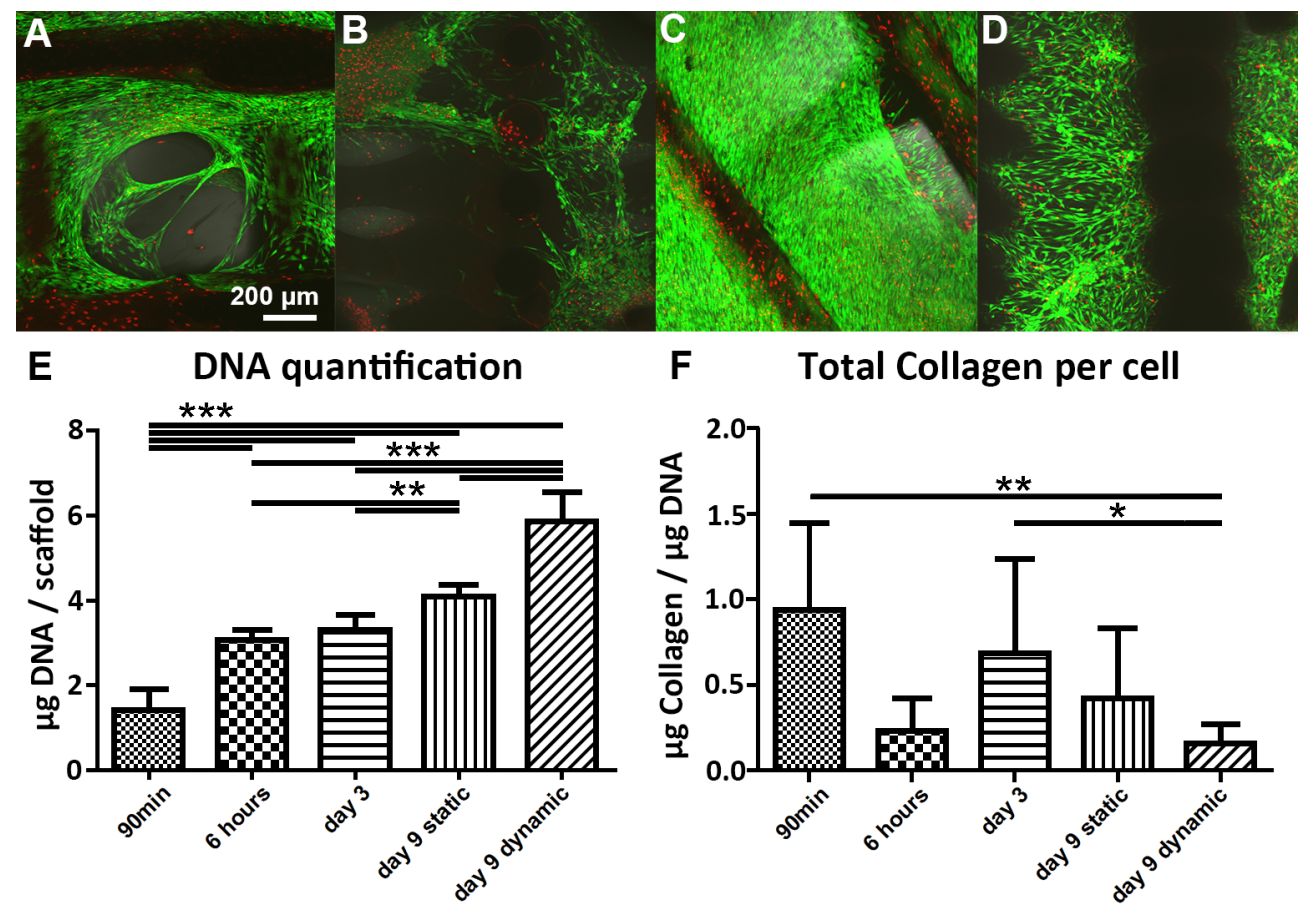

F Total Collagen per cell

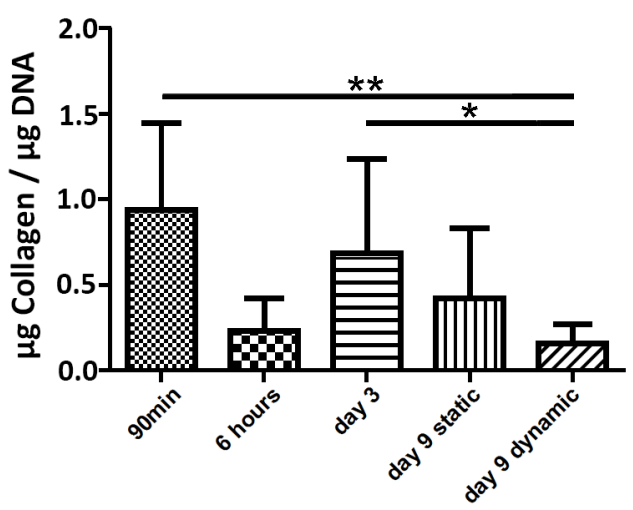

Figure 4.1: Live/dead staining showed a high cell viability of fetal hMSCs after 9 days of culture in static condition (A, B) and after 3 days of culture in static condition followed by 6 days of culture in a convection bioreactor $(\mathrm{C}, \mathrm{D})$ by confocal microscopy on a top-view (A, C) and on a cross-sectional view (B, D) of the scaffold. Higher numbers of cells were found in the scaffolds after convection culture compared to the scaffolds from static culture. This was confirmed by DNA quantification (E) where a significant difference in cell number was found between static and convection culture. (F) Collagen production per cell significantly decreased upon dynamic culture compared to 1 day of static culture subsequent to 90 minutes of seeding in a concentrated suspension and to 3 days of static culture. (90 min and 6 hours $(\mathrm{n}=5)$, day $3(\mathrm{n}=10)$, day 9 static $(\mathrm{n}=12)$, day 9 dynamic $(\mathrm{n}=14), * \mathrm{p}<0.05, * * \mathrm{p}<40.01$, $* * * \mathrm{p}<0.001)$ 
detection system (Bio-Rad) under the following conditions: cDNA was denatured for 10 minutes at $95{ }^{\circ} \mathrm{C}$, followed by 40 cycles, consisting of 15 seconds at $95{ }^{\circ} \mathrm{C}$, 30 seconds at $60{ }^{\circ} \mathrm{C}$, and 30 seconds at $72{ }^{\circ} \mathrm{C}$. For each reaction, a melting curve was generated to test primer dimer formation and non-specific priming. The cycle threshold $(\mathrm{Ct})$ values were determined with the Bio-Rad iQ5 optical system software, in which a threshold value was set for the fluorescent signal at the lower log-linear part above the baseline. Ct values were normalized to the B2M housekeeping gene and $\Delta \mathrm{Ct}$ ((average of $\left.\left.\mathrm{Ct}_{\text {control }}\right)-\mathrm{Ct}_{\text {value }}\right)$. Results are expressed as relative mRNA expression normalized to the gene expression levels of hfMSCs from T25 day 0 and calculated as $2^{-\triangle C t}$.

For gene expression analysis of haMSCs, samples were seeded statically for 3 days followed by another 6 days of static culture or 6 days of dynamic culture in convection or perfusion flow. After culture, medium was aspirated from the scaffolds, the samples were transferred to $2 \mathrm{~mL}$ eppendorf tubes and stored at $-80{ }^{\circ} \mathrm{C}$. Samples for basal gene expression analysis, referred to as T25 day 0, were retrieved from two-dimensional culture in T25 tissue culture flasks (NUNC) by adding $500 \mu \mathrm{L}$ of TRIzol (Invitrogen) upon reaching 70\% confluence. RNA isolation, cDNA synthesis and RT-PCR were carried out as described for hfMSCs. Results are expressed as relative mRNA expression normalized to the gene expression levels of haMSCs from T25 day 0 and calculated as $2^{-\triangle C t}$.

\subsubsection{Scanning electron microscopy (SEM) analysis}

Cell morphology, attachment and distribution were characterized by SEM analysis with a Philips XL 30 ESEM-FEG. Samples were fixed for 30 minutes in $10 \%$ formalin. Subsequently, the samples were dehydrated in sequential ethanol series and critical point dried from liquid carbon dioxide using a Balzers CPD 030 Critical Point Dryer. The constructs were gold sputter coated (Cressington) prior to SEM analysis. SEM images were obtained under high vacuum with an acceleration voltage of $30 \mathrm{kV}$ and a working distance of $10 \mathrm{~mm}$.

\subsubsection{Methylene blue staining}

Cell morphology, attachment and distribution of haMSCs was qualitatively assessed by methylene blue staining. Samples were fixed for 30 minutes in $10 \%$ formalin, washed with PBS twice and stained with methylene blue (Sigma) for 30 seconds immediately followed by extensive washing with DI-water until the water remained colorless. The samples were imaged using a stereomicroscope (Nikon SMZ800 with Q-imaging Retiga 1300 camera).

\subsubsection{Histological analysis}

Samples were fixed after live/dead imaging or directly after culture for 30 minutes in $10 \%$ formalin and stored in PBS at $5{ }^{\circ} \mathrm{C}$ until further processing. Samples were dehydrated using a sequential ethanol series (60, 70, 80, 90, 96 and 100\% ethanol, 30 minutes for each step), and subsequently embedded in glycol methacrylate (GMA). The obtained blocks were sectioned at $5 \mu \mathrm{m}$ intervals, and stained with hematoxylin 
and eosin (H\&E, Sigma) for visualization of the nuclei and cytoplasm, and Masson Trichrome to stain for collagen-like ECM formation.

\subsubsection{Statistical analysis}

Results are presented as mean \pm standard deviation, and compared using either oneway ANOVA (multiple conditions) with a Bonferroni posttest or Student t-test (two conditions). Statistical significance was set to $\mathrm{p}$ - value $<0.05(*)$.

\subsection{Results}

\subsubsection{Viability, distribution and gene expression profile of hfMSCs}

Scaffolds seeded with hfMSCs showed comparable viability in both static and convection culture after 9 days (Figure 4.1A and C, respectively). A high viability was also found 6 hours after seeding (Figure S4.1A-B) and after 3 days of static culture (Figure S4.1C-D). The number of hfMSCs and their distribution seemed to be enhanced when the constructs were cultured in convection flow, which could be observed in the cross-sectional view of the scaffolds for static (Figure 4.1B) and for dynamic culture (Figure 4.1D). Also the morphology of the cells in the pores of the scaffold appeared more spread after dynamic culture (Figure S4.1E-H). The difference in cell number was confirmed by DNA quantification (Figure 4.1E).

Both static and convection culture showed an increase in cell number over time, yet the increase in convection culture was significantly higher than in static culture. Furthermore, it could be seen that allowing the cells to adhere to the scaffold initially for 6 hours before adding medium resulted in a significant higher cell seeding efficiency than when the medium was added already after 1.5 hour of incubation.

A hydroxyproline assay was performed to determine the total amount of intra and extracellular collagen, which is a measure for cells activity and ECM formation (Figure 4.1F). A small increase in total collagen production was observed between 6 hours and 3 days of static culture, whereas the DNA content remained similar. The total collagen production per cell seemed to decrease over time both in static and dynamic culture compared to the collagen production 90 minutes after seeding. Yet, the DNA content increased over time while the total collagen content per scaffold remained constant for these conditions, thus suggesting that hfMSCs were mainly proliferating.

Gene expression levels (Figure 4.2) of ALCAM (CD166, activated leukocyte cell adhesion molecule) and CD63, both indicators for stemness [21], fluctuated over time in static culture. ALCAM and CD63 were similarly expressed after 9 days in both static and convection culture compared to the basal level of ALCAM and CD63 at T25 day 0. F-Actin mRNA expression showed a significant two-fold up-regulation in dynamic culture and a two-fold down-regulation in static culture after 9 days. A similar but less robust trend was found for Runx2 (Runt-related transcription factor 2 ), associated with early osteogenic differentiation. 


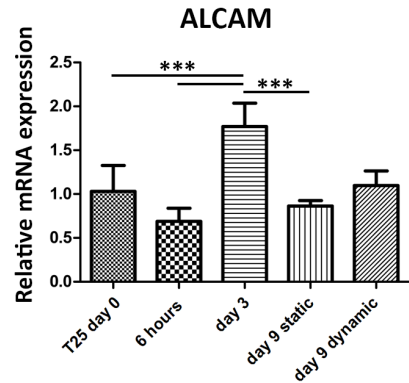

Sox9

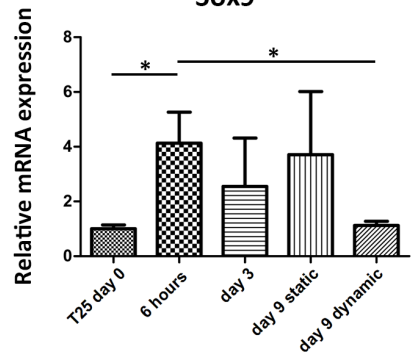

ALP

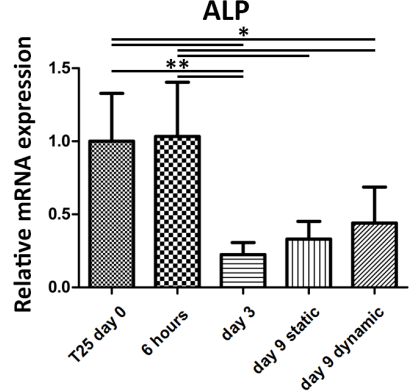

CD63

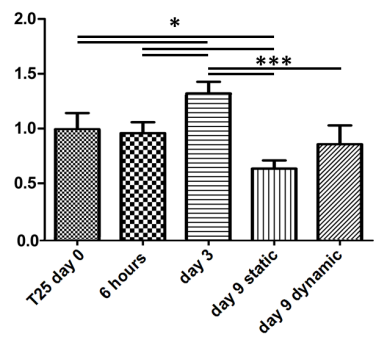

Col-1

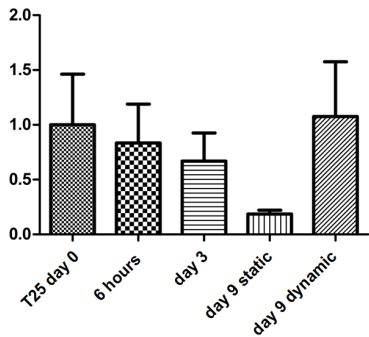

ACAN

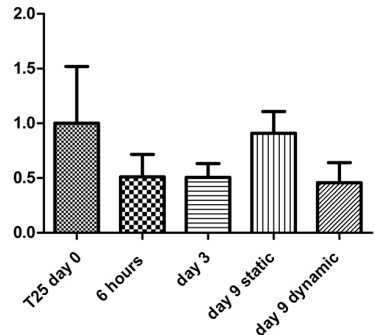

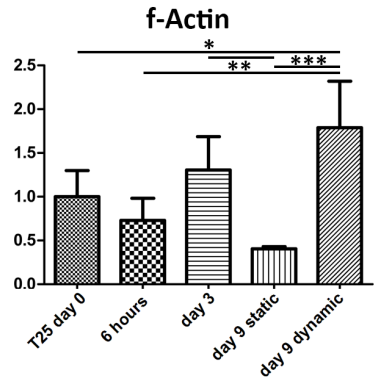

Col-2

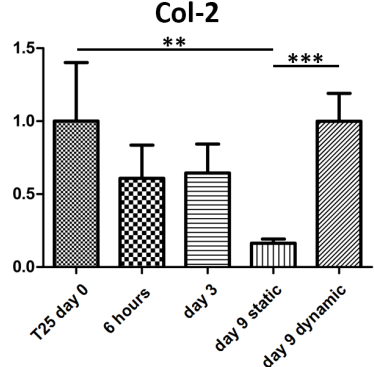

Runx2

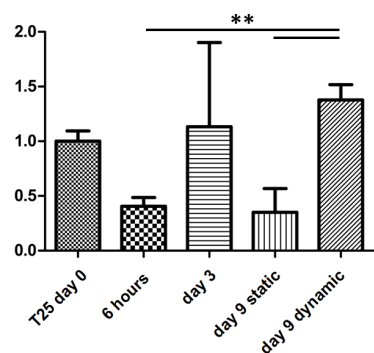

Figure 4.2: Relative mRNA expression levels were assessed by qPCR. The basal mRNA expression levels were determined for hfMSCs from 2D culture on tissue culture treated polystyrene (T25 day 0). ALCAM and CD63, both genes associated with the maintenance of stemness, did not show significant differences between the basal gene expression levels and the expression levels after 9 days of static or convection culture. F-Actin showed a slight down-regulation after 9 days in static culture and a significant up-regulation after 3 days static followed by 6 days convection culture. This same trend was found for Runx2. ALP was down-regulated for both static and convection culture. ACAN and Sox9 were down-regulated in convection culture. Col-1 and col-2, markers for ECM production, were down-regulated in time in static culture, but retained basal expression levels when the scaffolds were placed in convection culture. ( $\mathrm{n}=4$ except for day 9 dynamic $(\mathrm{n}=5), * \mathrm{p}<0.05, * * \mathrm{p}<0.01, * * *$ $\mathrm{p}<0.001)$ 


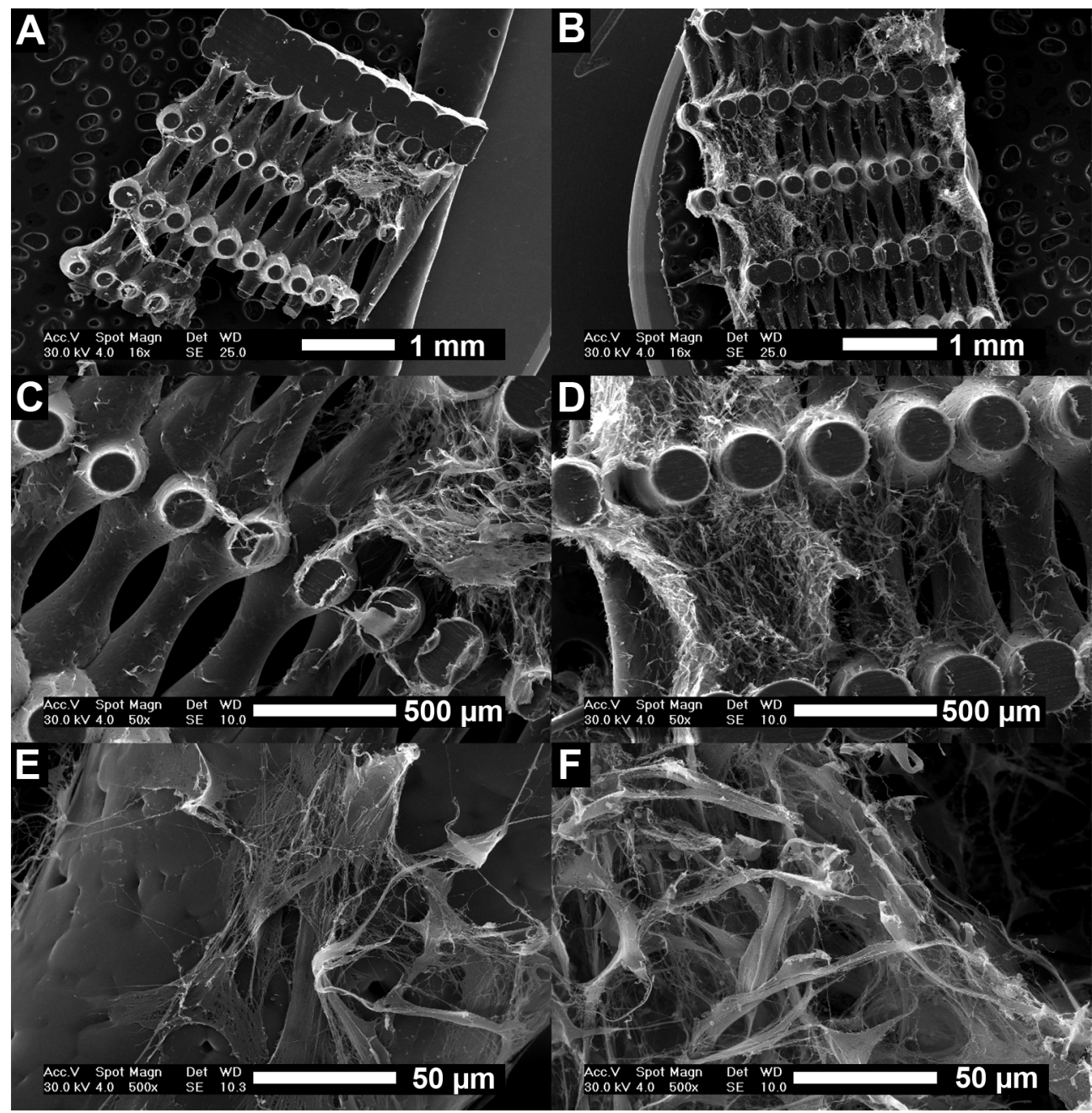

Figure 4.3: Scanning electron microscopy images of the distribution of hfMSCs throughout the scaffolds after 9 days of static culture (A, C, E) and after 3 days of static followed by 6 days of dynamic convection culture in a biaxial rotating bioreactor $(\mathrm{B}, \mathrm{D}, \mathrm{F})$. 


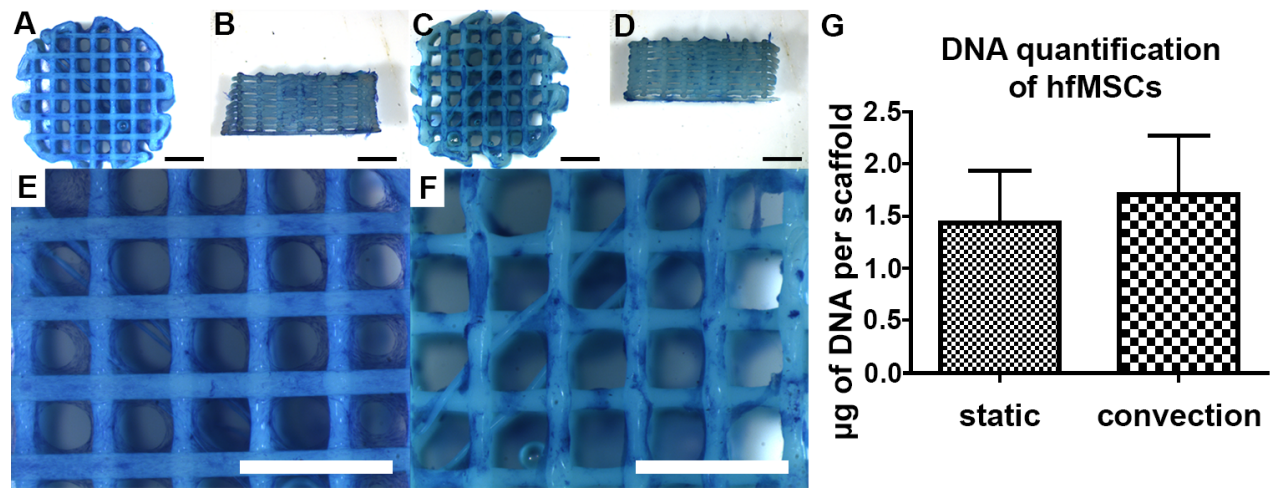

Figure 4.4: The distribution of haMSCs after 9 days of static culture (A, B, E) and after 3 days of static followed by 6 days of convection culture $(\mathrm{C}, \mathrm{D}, \mathrm{F})$. DNA assay was performed as a measure of cell number per scaffold $(G)$. No significant difference in cell number was found between static and convection culture $(\mathrm{n}=6)$. Scale bars represent $2 \mathrm{~mm}$.

Alkaline phosphatase (ALP) expression, involved in osteogenesis, was downregulated over time both for static and dynamic culture. Aggrecan (ACAN), a marker for chondrogenesis, did not show any significant differences between any of the conditions. Yet, Sox9, an early marker for chondrogenesis, was up-regulated in static culture, whereas convection culture restored the mRNA expression levels similar to the levels at T25 day 0. Collagen-1 (col-1) and collagen-2 (col-2) markers for ECM proteins, abundantly present in bone and cartilage respectively, were both downregulated over time in static culture, whereas their expression levels were restored upon convection culture.

SEM analysis was performed on cross-sections of the scaffolds after 9 days of culture to assess cell distribution, morphology and tissue formation (Figure 4.3). Statically cultured scaffolds (Figure 4.3A, C and E) showed lower cell numbers compared to dynamically cultured scaffolds (Figure 4.3B, D and F). A cell sheet of hfMSCs was formed on the bottom of both the statically cultured and dynamically cultured scaffolds. The cellular distribution appeared more homogeneous after convection culture compared to static culture and the cells invaded the longitudinal pores of the scaffold more profoundly in convection culture.

There were no large differences observed in ECM formation and cell morphology between static and convection culture. In both conditions the cells were spread while partly attached to the scaffold material or the secreted ECM. The formed tissue appeared relatively open inside the pores of the scaffolds whereas the outer layer of tissue found at the bottom or top of the scaffold appeared as a more dense and closed membrane. From the SEM analysis after 6 hours (Figure S4.2A-C) and 3 days of static culture (Figure S4.2D-F) it could be seen that the cell morphology changed over time from a rounded shape to a more spread morphology. Similar cell-shape changes were observed in 2D culture where hfMSCs showed a more spread morphology upon attachment to the substrate material. This change in cellular morphology could also be observed in histological analysis by H\&E staining (Figure S4.3). Further analysis 
with Masson Trichrome staining showed collagen-like materials stained green, which did not show any differences between static and convection culture after 9 days of culture (Figure S4.4).

\subsubsection{The cell adherence, distribution and gene expression profile of haMSCs}

To evaluate whether the increase in cell number and improvement of cell distribution found with hfMSCs can be translated directly to clinically more relevant haMSCs, a comparative study with the biaxial rotating vessel bioreactor was performed. A methylene blue staining after 9 days of static (Figure 4.4A, B and E) and 3 days static followed by 6 days dynamic convection culture (Figure 4.4C, D and F) showed no improvement on cell number and cellular distribution. In static culture, haMSCs adhered to the fibers and partly filled the pores of the scaffold probably upon proliferation and ECM production (Figure 4.4E).

In dynamic culture, the cells did not fill the pores of the scaffold to the same extend as the cells in static culture. From the cross-sectional view (Figure 4.4B and D) it could be observed that the distribution of the cells throughout the scaffold was still limited in both conditions. DNA content was quantified for two donors in triplicate and averaged per culture condition (Figure 4.4G). The results showed a relatively low DNA content (about a 3-fold less compared to hfMSCs) in both conditions without a significant difference between the two conditions. The DNA quantities and cell distribution of the two separate donors was also compared with 6 days of dynamic culture in a perfusion bioreactor (Figure S4.5). For donor 1, a slight increase in DNA content is found upon dynamic culture compared to static culture. Donor 2 , however, shows a significant difference between static and perfusion culture, and between convection and perfusion culture. For this same donor, higher cell numbers were also observed in static culture compared to convection or perfusion culture when the constructs were cultured statically for 31 days prior to a 14 days culture in the two dynamic systems (Figure S4.6). These findings were confirmed by DNA assay in which a significant drop in DNA content was observed after the scaffolds were cultured in convection or perfusion culture compared to the DNA content after 31 and 45 days of static culture (Figure S4.7).

The gene expression profile of haMSCs was assessed for the same genes as hfMSCs (Figure 4.5). The gene expression levels were determined after 9 days of static culture and after 3 days of static culture followed by 6 days of dynamic culture in a convection or perfusion culture bioreactor and compared to the basal gene expression levels at day 0. A significant two-fold down-regulation of ALCAM was found for haMSCs cultured in a perfusion bioreactor compared to the basal levels at day 0 , static culture at day 9 and convection culture. ALP showed a significant down regulation in all scaffold cultures compared to the basal levels in 2D culture. F-Actin, col-1 and col-2 also showed a significant down-regulation in both dynamic culture systems compared to the basal levels, yet for these genes no significant differences were found between the basal gene expression levels and the levels after 9 days of static culture. Sox 9 was significantly up-regulated after 9 days of static culture and ACAN was up-regulated 
a 5-fold in perfusion culture compared to static culture. However, this change was not statistically significant.

\subsection{Discussion}

Mesenchymal stromal cells (MSCs) derived from bone marrow have been used as a cellular source in several tissue engineering applications due to their availability, ease of isolation from autologous source and therewith reduced immunological related risks upon re-implantation. Moreover, MSCs have shown a certain degree of plasticity by the ability to differentiate and transdifferentiate after differentiation into several well defined cell lineages both in vitro and in vivo [22-25]. Ullah et al. have established a correlation between the expression of cell cycle genes and the ability of adipogenic differentiated hMSCs to transdifferentiate into osteogenic or chondrogenic differentiated cells [23]. In other studies, not all MSC populations exhibited similar multipotency, possibly due to differences in heterogeneity of MSCs populations, which resulted in different efficacies of MSC based therapies [26, 27].

The multipotency of MSCs is often assessed by soluble factor induced differentiation in which the results of histological or biochemical assays are used to characterize cell fate. However, instead of focusing on changes in MSCs phenotype by quantifying the expression of differentiation related genes, it could be also of interest to assess to what extent the cellular phenotype of MSCs can be maintained by investigating genes related to multipotency.

In the past decades, researchers focused on defining stemness and identifying stemness markers to be able to more directly assess the potency of patient-derived MSC populations [28]. A known drawback in the use of human adult MSC is their slow proliferation time and generally limited proliferation capacity. More recently, human fetal MSCs (hfMSCs) have been characterized, and have shown a higher proliferation and osteogenic differentiation capacity and reduced immunogenicity when compared to mesenchymal stem cell populations derived from the umbilical cord, adult adipose tissue or adult bone marrow in 3D culture systems both in vitro and in vivo [16]. Thus, populations of hfMSCs have a high potential as cell population for diverse study models as well as for potential clinical applications as an allogenic multipotent cell source. In this study, we have characterized hfMSCs viability and gene expression levels after culture in 3D scaffolds in static and dynamic culture conditions. Moreover, we have assessed hfMSCs behavior in 3D scaffolds with respect to cell attachment, proliferation, and genetic profile and compared this to the behavior of haMSCs in static and dynamic culture conditions.

Static and dynamic culture conditions both resulted in similar cell viability on the PEOT/PBT scaffolds (Figure 4.1A-D). However, the number of hfMSCs in dynamic culture was higher (Figure 4.1E) and the distribution of the cells throughout the scaffolds seemed to be improved with respect to the scaffolds in static culture (Figure 4.1A-D and Figure 4.3). With respect to the gene expression levels, it could be concluded that 6 days of dynamic culture subsequent to 3 days of static culture restored the basal gene expression levels, found at day 0 in $2 \mathrm{D}$ static culture, for all genes except ALP and f-Actin. Similar results were found by a study of Katayama et al., in which no change in gene expression levels of stem cell markers such as 

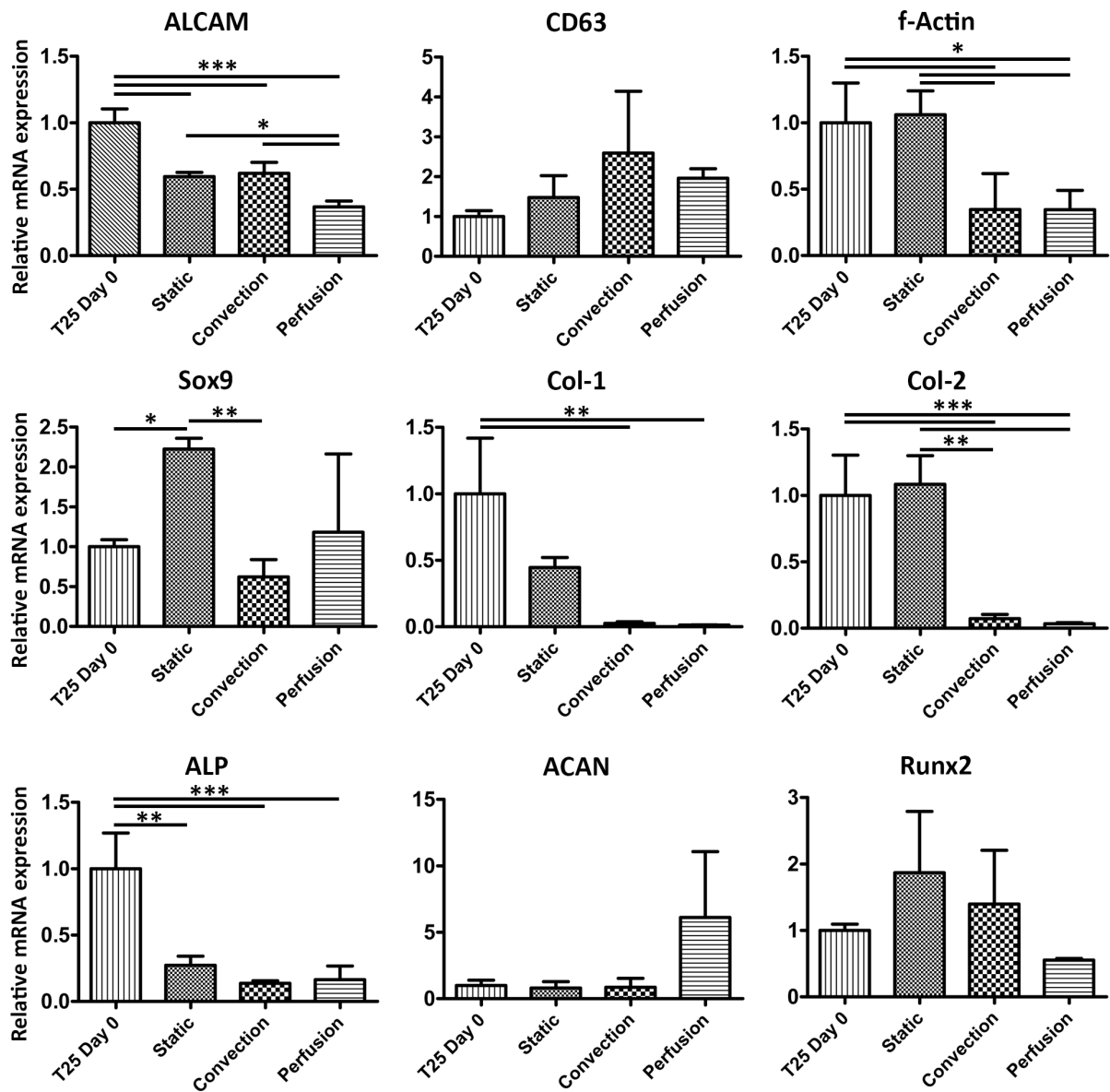

Figure 4.5: Relative mRNA expression levels of haMSCs in static, convection and perfusion culture were assessed by qPCR. ALCAM showed a two-fold significant down-regulation after 9 days of perfusion culture compared to static and convection culture. F-Actin showed a down-regulation after 9 days in both dynamic culture systems compared to static culture. Col-1 and col-2, markers for extra-cellular matrix production, were down-regulated in both dynamic culture systems. ACAN showed a ten-fold up-regulation after perfusion culture compared to static and convection culture, however, this change was not statistically significant. $(\mathrm{n}=3, * \mathrm{p}<0.05, * * \mathrm{p}<0.01, * * * \mathrm{p}<0.001)$ 
ALCAM was found in adult hMSCs cultured on collagen sheets under perfusion flow [29]. Considering the genes involved in ECM production such as f-Actin, col-1 and col-2, static culture seemed to provide insufficient cues to the cells to activate ECM formation related pathways. Although f-Actin showed a statistically significant upregulation in dynamic culture and a slight down-regulation in static culture after 9 days, these relative changes were less than a two-fold and, therefore, its biological relevance is diminished. Col-1 and col-2 expression was maintained in dynamic culture and down-regulated in static culture. This indicated that the hfMSCs in dynamic culture probably experienced shear forces, due to the convection flow, resulting in activation of the f-Actin pathway among others, which could subsequently lead to an increase in tissue formation [30]. Furthermore, shear forces have been known to induce osteogenic differentiation which could explain the initial significant decrease of ALP expression in static culture and the subsequent small increase in ALP in convection culture (Figure 4.2) [31]. On the other hand, a recent study of Kock et al. has shown a negative influence of perfusion flow on cartilage-like ECM production of chondrogenic pre-differentiated hMSCs, although these changes were not evident from gene expression analysis [32]. In our study, changes in most of the gene expression levels in hfMSCs were of minor importance since they only represent a two-fold up or down-regulation even when significantly different.

SEM analysis (Figure 4.3E-H) supported the hypothesis of a direct relation between f-Actin gene expression and tissue growth. An increase in tissue formation and tissue density was observed for dynamically cultured samples compared to statically cultured scaffolds. It could be that cells in static culture were residing in a less proliferative or even quiescent state due to the absence of differentiation or metabolism stimulating factors.

Although six days of convection culture has more or less altered the gene expression levels compared to static culture, no difference was found on total collagen production by biochemical and histological analysis (Figure 4.1F and Figure S4.4E-H, respectively). A subsequent six days of culture in a convection bioreactor was probably not sufficient to trigger the cells to actively remodel their already formed ECM. However, the number of cells in the interior of the scaffold under dynamic conditions was higher than under static conditions, indicating that dynamic culture did improve cellular distribution.

Although hfMSCs have shown some beneficial properties over haMSCs in previous studies, the application of haMSCs remained of interest due to their more immediate clinical relevance. Fetal MSCs cannot be used from autologous source and their use involves more ethical issues. Therefore, the use of haMSCs on these scaffolds in the biaxial rotating vessel bioreactor was evaluated as well. A perfusion flow bioreactor was introduced in parallel to be able to compare the results obtained in the convection culture to both static and perfusion culture conditions [20]. The cell number of haMSCs per scaffold assessed by DNA assay after 9 days of static culture was found to be much lower for both haMSC donors (Figure S4.5D) compared to hfMSCs (Figure 4.1E). The cell seeding efficiency of haMSCs has already shown to be limited and donor dependent in one of our previous studies, in which several seeding parameters were optimized to decrease cell loss after seeding [9]. The treatment of scaffolds for hfMSCs culture with argon plasma could have improved the hfMSCs 
adherence compared haMSCs which were cultured on non-treated scaffolds. However, in previous studies with haMSCs on non-treated, oxygen plasma treated and argonplasma treated PEOT/PBT films and PEOT/PBT rapid prototyped scaffolds, no evidence for improved cell adherence was found (data not shown).

For the two haMSCs donors no difference in the number of cells was found upon convection culture compared to static culture conditions. Similar results were found in a study of Stiehler et al., in which hMSCs seeded on PLGA-based scaffolds did not show any difference in cell number after 7 days of convection culture compared to static culture [33]. In other studies, perfusion culture was applied on porous 3D scaffolds and showed to improve cell proliferation and scaffold colonization [13, 3437]. In our study, however, perfusion culture showed to significantly decrease the number of haMSCs from donor 2 compared to static or convection culture conditions. This could be due to the highly interconnected and organized pore network of rapid prototyped scaffolds compared to more conventional sponges and non-woven scaffolds with random fiber organization. A similar negative effect was reported in a study by Bjerre et al. in which perfusion culture unfavorably changed the morphology and vitality of haMSCs [38].

Differences in initial cell attachment between the two donors could be an effect of differences in heterogeneity of cell populations due to donor variation [9, 22, 39-41]. Changes in cell response to the introduction of perfusion flow could also be related to several other factors such as the amount of ECM produced at the moment of transfer from static culture to the perfusion flow system and the distribution of the cells and ECM throughout the scaffold. Upon closure of the longitudinal pores of the scaffold due to the presence of the ECM formed in static culture, the pressure or the perfusion flow is expected to be increased which could have led to tissue detachment.

We hypothesized that prolonging the static culture period prior to applying dynamic culture could result in more ECM with stronger binding and entanglement to the scaffold material [6]. Therefore, the scaffolds were cultured statically for 31 days followed by 14 days of dynamical culture in convection or perfusion flow. From cross-sectional views on methylene blue stained scaffolds (Figure S4.6), it could be observed that the cells and tissues still seemed to be detach from the scaffold upon dynamic culture, whereas in static conditions a homogeneous distribution of cells and tissue throughout the scaffold was found. These results were confirmed by DNA quantification which showed a significant loss of cells upon transferring the constructs from static to dynamic culture (Figure S4.7). In both convection and perfusion flow culture conditions, loosened cell sheets were found in the longitudinal pores of the scaffolds. A difference between the two dynamic systems was found with respect to the adherence sites of the cells. In perfusion culture conditions cells were found on the outer layer of scaffold material, whereas in convection flow conditions less cells were found to reside on the outer layer of the scaffold.

The gene expression levels of f-Actin, col-1 and col-2 previously showed to be significantly up-regulated in hfMSCs, whereas a significant down-regulation was found in haMSCs when comparing the basal gene expression levels and the levels after 9 days of static culture to the levels after 3 days of static culture followed by 6 days of dynamic culture. For Sox9 a similar response was found for hfMSCs compared to haMSCs. ALCAM, CD63 and ACAN did not show any significant differences in 
hfMSCs and haMSCs cultured statically or dynamically in convection culture.Larger differences in gene expression levels were found between perfusion culture and static culture than between convection culture and static culture. ALCAM, f-Actin, col-1 and col-2 were significantly down-regulated in perfusion culture compared to static culture after 9 days. This could have been related to the lower cell number as a consequence of relatively high shear forces involved in a perfusion culture system. As mentioned previously, shear forces could result in an increase in the gene expression of cell adherence related markers. However, when cells and cell-sheets loosened upon convection or perfusion flow due to poor adherence to the biomaterial, the cells that remained in the scaffolds could have resided in areas where the shear forces were not applied. Cells could, for example, reside in between the fibers of the scaffold instead of in the longitudinal pores of the scaffold in the case of perfusion flow. Furthermore, cells that were embedded in cell sheets that were subsequently loosened upon perfusion flow probably had limited interaction with the scaffold material. This ultimately might have resulted in the activation of other pathways than for cells that were in direct contact with the scaffold material.

Overall, the results presented in this study suggested that a more homogeneous cell distribution could be obtained for fetal MSCs compared to adult ones in all conditions, and that the benefit of applying dynamic culture over static culture was not obvious for adult MSCs. Although the experiments with haMSCs were not as successful as with hfMSCs with respect to cell number and distribution, we believe there is still the potential for a dynamic bioreactor system in a later stage of tissue culture with haMSCs. When static cultures lead to complete filling of the scaffold with closure of the pores, cells in the scaffold interior might undergo necrosis by mass transfer limitations. At that stage, a dynamic system such as the biaxial rotating vessel presented in this study, might become favorable over static culture. Furthermore, in our study the complex influence of rotational speed and medium perfusion speed on the fluid dynamics was not modeled. Screening the influence of these parameters on MSC fate in rapid prototyped scaffolds might result in optimal culture conditions in which a homogeneous distribution throughout the scaffold can be achieved without compromising cells viability or unfavorably altering MSCs phenotype.

\subsection{Conclusion}

The biaxial rotating vessel bioreactor used in this study has shown to improve hfMSCs distribution and proliferation in $3 \mathrm{D}$ rapid prototyped PEOT/PBT scaffolds. The hfMSCs in convection flow produced ECM like material while retaining a comparable gene expression profile as the basal levels of hfMSCs seeded statically in 2D. Static culture on 3D scaffolds with hfMSCs showed down-regulation of f-Actin, col-1, col-2, ALP and runx2 gene expression levels and also resulted in less ECM production and lower cell numbers than in convection culture. The increased cell number and cellular distribution upon convection culture was not observed for haMSCs, even after an extended period of static culture prior to dynamic culture. Also the gene expression profile of haMSCs showed a different response to the introduction of convection flow than the profile of hfMSCs. As a third well-known dynamic culture system, a perfusion bioreactor was introduced. Perfusion flow has shown to negatively influence 
the number of haMSC. Furthermore, haMSCs phenotype was altered differently than hfMSCs phenotype after dynamic culture in both the convection and the perfusion flow bioreactor compared to static culture. Yet, the biaxial rotating vessel bioreactor has shown to maintain hfMSCs viability and distribution throughout the scaffold, without inducing differentiation. Therefore, this system could be further optimized and serve as a tool to study cell activity in distinct 3D scaffolds upon the addition of soluble factors.

\section{Acknowledgements}

The authors gratefully acknowledge the funding from the Netherlands Institute for Regenerative Medicine (NIRM) through the grant number FES0908. The authors would like to acknowledge Hui-Lun Soh from Quintech Life Sciences Pte Ltd Singapore for her help in the experiments regarding hfMSCs. 


\section{References}

[1] Langer R, Vacanti JP. Tissue engineering. Science. 1993;260:920-6.

[2] Moroni L, de Wijn JR, van Blitterswijk CA. Three-dimensional fiber-deposited PEOT/PBT copolymer scaffolds for tissue engineering: influence of porosity, molecular network mesh size, and swelling in aqueous media on dynamic mechanical properties. Journal of biomedical materials research. 2005;75:957-65.

[3] Reichert JC, Cipitria A, Epari DR, Saifzadeh S, Krishnakanth P, Berner A, et al. A Tissue Engineering Solution for Segmental Defect Regeneration in Load-Bearing Long Bones. Sci Transl Med. 2012;41:280-287.

[4] Woodfield TBF, Malda J, de Wijn J, Peters F, Riesle J, van Blitterswijk CA. Design of porous scaffolds for cartilage tissue engineering using a three-dimensional fiber-deposition technique. Biomaterials. 2004;25:4149-61.

[5] Kim J, McBride S, Tellis B, Alvarez-Urena P, Song YH, Dean DD, et al. Rapid-prototyped PLGA/beta-TCP/hydroxyapatite nanocomposite scaffolds in a rabbit femoral defect model. Biofabrication. 2012;4:025003.

[6] Griffon DJ, Abulencia JP, Ragetly GR, Fredericks LP, Chaieb S. A comparative study of seeding techniques and three-dimensional matrices for mesenchymal cell attachment. Journal of tissue engineering and regenerative medicine. 2011;5:169-79.

[7] Sobral JM, Caridade SG, Sousa RA, Mano JF, Reis RL. Three-dimensional plotted scaffolds with controlled pore size gradients: Effect of scaffold geometry on mechanical performance and cell seeding efficiency. Acta biomaterialia. 2011;7:1009-18.

[8] Wang H, Pieper J, Peters F, van Blitterswijk CA, Lamme EN. Synthetic scaffold morphology controls human dermal connective tissue formation. Journal of biomedical materials research. 2005;74:523-32.

[9] Leferink AM, Hendrikson WJ, Rouwkema J, Karperien M, van Blitterswijk CA, Moroni L. Increased cell seeding efficiency in bioplotted three-dimensional PEOT/PBT scaffolds. Journal of tissue engineering and regenerative medicine. 2013;DOI:10.1002/term.1842

[10] Chen M, Le DQ, Baatrup A, Nygaard JV, Hein S, Bjerre L, et al. Self-assembled composite matrix in a hierarchical 3-D scaffold for bone tissue engineering. Acta biomaterialia. 2011;7:2244-55.

[11] Papadimitropoulos A, Riboldi SA, Tonnarelli B, Piccinini E, Woodruff MA, Hutmacher DW, et al. A collagen network phase improves cell seeding of open-pore structure scaffolds under perfusion. Journal of tissue engineering and regenerative medicine. 2013;7:183-91.

[12] Schantz JT, Machens HG, Schilling AF, Teoh SH. Regenerative medicine: implications for craniofacial surgery. The Journal of craniofacial surgery. 2012;23:530-6.

[13] Grayson WL, Marolt D, Bhumiratana S, Frohlich M, Guo XE, Vunjak-Novakovic G. Optimizing the medium perfusion rate in bone tissue engineering bioreactors. Biotechnol Bioeng. 2011;108:115970 .

[14] Martin I, Wendt D, Heberer M. The role of bioreactors in tissue engineering. Trends Biotechnol. 2004;22:80-6.

[15] Singh H, Teoh SH, Low HT, Hutmacher DW. Flow modelling within a scaffold under the influence of uni-axial and bi-axial bioreactor rotation. J Biotechnol. 2005;119:181-96.

[16] Zhang ZY, Teoh SH, Chong MS, Schantz JT, Fisk NM, Choolani MA, et al. Superior osteogenic capacity for bone tissue engineering of fetal compared with perinatal and adult mesenchymal stem cells. Stem Cells. 2009;27:126-37.

[17] Zhang ZY, Teoh SH, Chong WS, Foo TT, Chng YC, Choolani M, et al. A biaxial rotating bioreactor for the culture of fetal mesenchymal stem cells for bone tissue engineering. Biomaterials. 2009;30:2694-704.

[18] Chan J, Waddington SN, O'Donoghue K, Kurata H, Guillot PV, Gotherstrom C, et al. Widespread distribution and muscle differentiation of human fetal mesenchymal stem cells after intrauterine transplantation in dystrophic mdx mouse. Stem Cells. 2007;25:875-84.

[19] de Bruijn JD, van den Brink I, Mendes S, Dekker R, Bovell YP, van Blitterswijk CA. Bone in- 
duction by implants coated with cultured osteogenic bone marrow cells. Advances in dental research. 1999;13:74-81.

[20] Janssen FW, Oostra J, Oorschot A, van Blitterswijk CA. A perfusion bioreactor system capable of producing clinically relevant volumes of tissue-engineered bone: in vivo bone formation showing proof of concept. Biomaterials. 2006;27:315-23.

[21] Jeannet R, Cai Q, Liu H, Vu H, Kuo YH. Alcam regulates long-term hematopoietic stem cell engraftment and self-renewal. Stem Cells. 2013;31:560-71.

[22] Phinney DG, Kopen G, Righter W, Webster S, Tremain N, Prockop DJ. Donor variation in the growth properties and osteogenic potential of human marrow stromal cells. Journal of Cellular Biochemistry. 1999;75:424-36.

[23] Ullah M, Stich S, Notter M, Eucker J, Sittinger M, Ringe J. Transdifferentiation of mesenchymal stem cells-derived adipogenic-differentiated cells into osteogenic- or chondrogenic-differentiated cells proceeds via dedifferentiation and have a correlation with cell cycle arresting and driving genes. Differentiation; research in biological diversity. 2013;85:78-90.

[24] Song L, Tuan RS. Transdifferentiation potential of human mesenchymal stem cells derived from bone marrow. Faseb J. 2004;18:980-2.

[25] Grove JE, Bruscia E, Krause DS. Plasticity of bone marrow-derived stem cells. Stem Cells. 2004;22:487-500.

[26] Russell KC, Phinney DG, Lacey MR, Barrilleaux BL, Meyertholen KE, O'Connor KC. In vitro high-capacity assay to quantify the clonal heterogeneity in trilineage potential of mesenchymal stem cells reveals a complex hierarchy of lineage commitment. Stem Cells. 2010;28:788-98.

[27] Phinney DG. Biochemical heterogeneity of mesenchymal stem cell populations: clues to their therapeutic efficacy. Cell cycle. 2007;6:2884-9.

[28] Menicanin D, Bartold PM, Zannettino AC, Gronthos S. Genomic profiling of mesenchymal stem cells. Stem cell reviews. 2009;5:36-50.

[29] Katayama A, Arano T, Sato T, Ikada Y, Yoshinari M. Radial-flow bioreactor enables uniform proliferation of human mesenchymal stem cells throughout a three-dimensional scaffold. Tissue Eng Part C Methods. 2013;19:109-16.

[30] Sansores-Garcia L, Bossuyt W, Wada K, Yonemura S, Tao C, Sasaki H, et al. Modulating F-actin organization induces organ growth by affecting the Hippo pathway. The EMBO journal. 2011;30:2325-35.

[31] Yeatts AB, Geibel EM, Fears FF, Fisher JP. Human mesenchymal stem cell position within scaffolds influences cell fate during dynamic culture. Biotechnology and Bioengineering. 2012;109:238191.

[32] Kock LM, Malda J, Dhert WJ, Ito K, Gawlitta D. Flow-perfusion interferes with chondrogenic and hypertrophic matrix production by mesenchymal stem cells. Journal of biomechanics. 2013;DOI:10.1016/j.jbiomech.2013.11.006.

[33] Stiehler M, Bunger C, Baatrup A, Lind M, Kassem M, Mygind T. Effect of dynamic 3-D culture on proliferation, distribution, and osteogenic differentiation of human mesenchymal stem cells. Journal of biomedical materials research. 2009;89:96-107.

[34] Alvarez-Barreto JF, Linehan SM, Shambaugh RL, Sikavitsas VI. Flow perfusion improves seeding of tissue engineering scaffolds with different architectures. Ann Biomed Eng. 2007;35:429-42.

[35] Grayson WL, Bhumiratana S, Cannizzaro C, Chao PH, Lennon DP, Caplan AI, et al. Effects of initial seeding density and fluid perfusion rate on formation of tissue-engineered bone. Tissue engineering. 2008;14:1809-20.

[36] Bjerre L, Bunger CE, Kassem M, Mygind T. Flow perfusion culture of human mesenchymal stem cells on silicate-substituted tricalcium phosphate scaffolds. Biomaterials. 2008;29:2616-27.

[37] Schumacher M, Uhl F, Detsch R, Deisinger U, Ziegler G. Static and dynamic cultivation of bone marrow stromal cells on biphasic calcium phosphate scaffolds derived from an indirect rapid prototyping technique. Journal of materials science Materials in medicine. 2010;21:3039-48.

[38] Bjerre L, Bunger C, Baatrup A, Kassem M, Mygind T. Flow perfusion culture of human mesenchymal stem cells on coralline hydroxyapatite scaffolds with various pore sizes. Journal of biomed- 
ical materials research. 2011;97:251-63.

[39] Siddappa R, Licht R, van Blitterswijk C, de Boer J. Donor variation and loss of multipotency during in vitro expansion of human mesenchymal stem cells for bone tissue engineering. Journal of orthopaedic research : official publication of the Orthopaedic Research Society. 2007;25:1029-41.

[40] DiGirolamo CM, Stokes D, Colter D, Phinney DG, Class R, Prockop DJ. Propagation and senescence of human marrow stromal cells in culture: a simple colony-forming assay identifies samples with the greatest potential to propagate and differentiate. Brit J Haematol. 1999;107:275-81.

[41] Siegel G, Kluba T, Hermanutz-Klein U, Bieback K, Northoff H, Schafer R. Phenotype, donor age and gender affect function of human bone marrow-derived mesenchymal stromal cells. Bmc Med. 2013;DOI:10.1186/1741-7015-11-146. 


\section{Supplementary Information}

Table S1 Primer Sequences

\begin{tabular}{|c|c|c|}
\hline Gene & Forward Primer & Reverse Primer \\
\hline \hline B2M & GACTTGTCTTTCAGCAAGGA & ACAAAGTCACATGGTTCACA \\
\hline ALCAM & ACGATGAGGCAGACGAGATAAGT & CAGCAAGGAGGAGACCAACAA \\
\hline CD-63 & GCCCTTGGAATTGCTTTTGTCG & CATCACCTCGTAGCCACTTCT \\
\hline f-Actin & GGCATCCTCACCCTGAAGTA & GGTGTGGTGCCAGATTTTC \\
\hline Runx2 & GGAGTGGACGAGGCAAGAGTTT & AGCTTCTGTCTGTGCCTTCTGG \\
\hline ALP & ACAAGCACTCCCACTTCATC & TTCAGCTCGTACTGCATGTC \\
\hline ACAN & AGGCAGCGTGATCCTTACC & GGCCTCTCCAGTCTCATTCTC \\
\hline Sox9 & TGGGCAAGCTCTGGAGACTTC & ATCCGGGTGGTCCTTCTTGTG \\
\hline Col-1 & GTCACCCACCGACCAAGAAACC & AAGTCCAGGCTGTCCAGGGATG \\
\hline Col-2 & CGTCCAGATGACCTTCCTACG & TGAGCAGGGCCTTCTTGAG \\
\hline
\end{tabular}

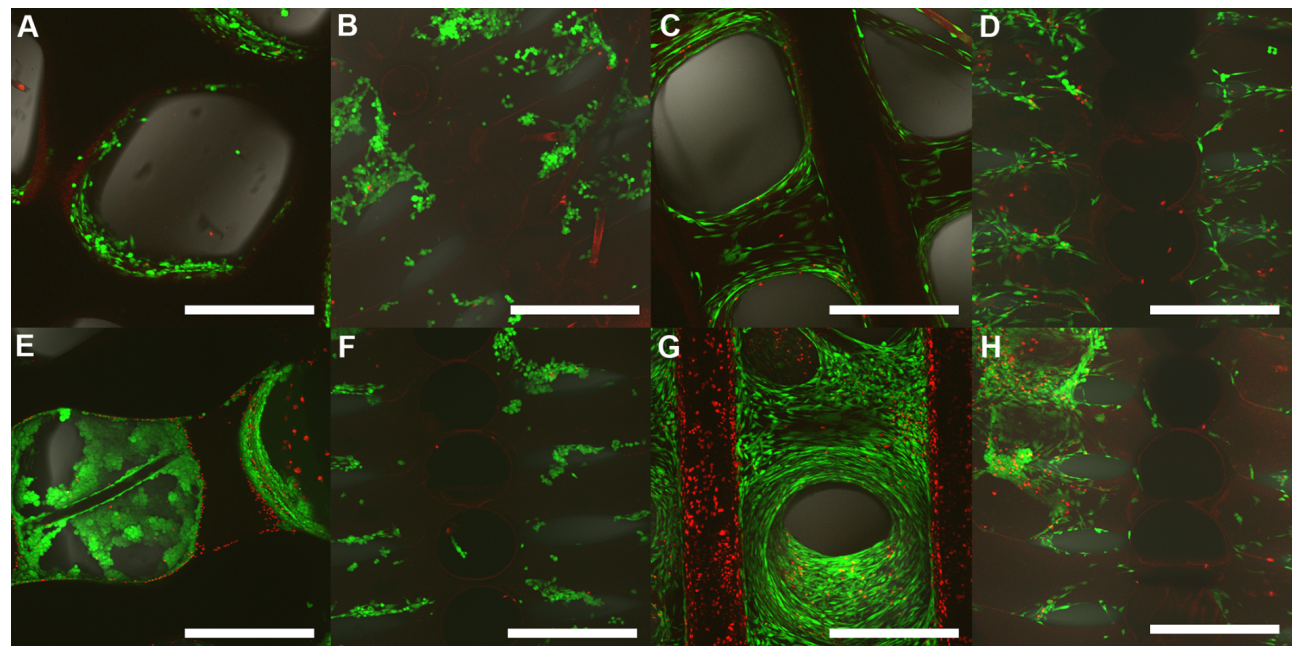

Figure S4.1: Live/dead staining of hfMSCs after 6 hours (A, B), 3 days (C, D) and 9 days (E, F) of static culture and after 3 days of static followed by 6 days of dynamic culture in a biaxial rotating bioreactor $(\mathrm{G}, \mathrm{H})$. In both static and dynamic culture cells showed high cell viability and an improved distribution with respect to earlier time-points. However, it seemed that in dynamic culture hfMSCs were present in higher numbers. Scale bars represent $500 \mu \mathrm{m}$. 


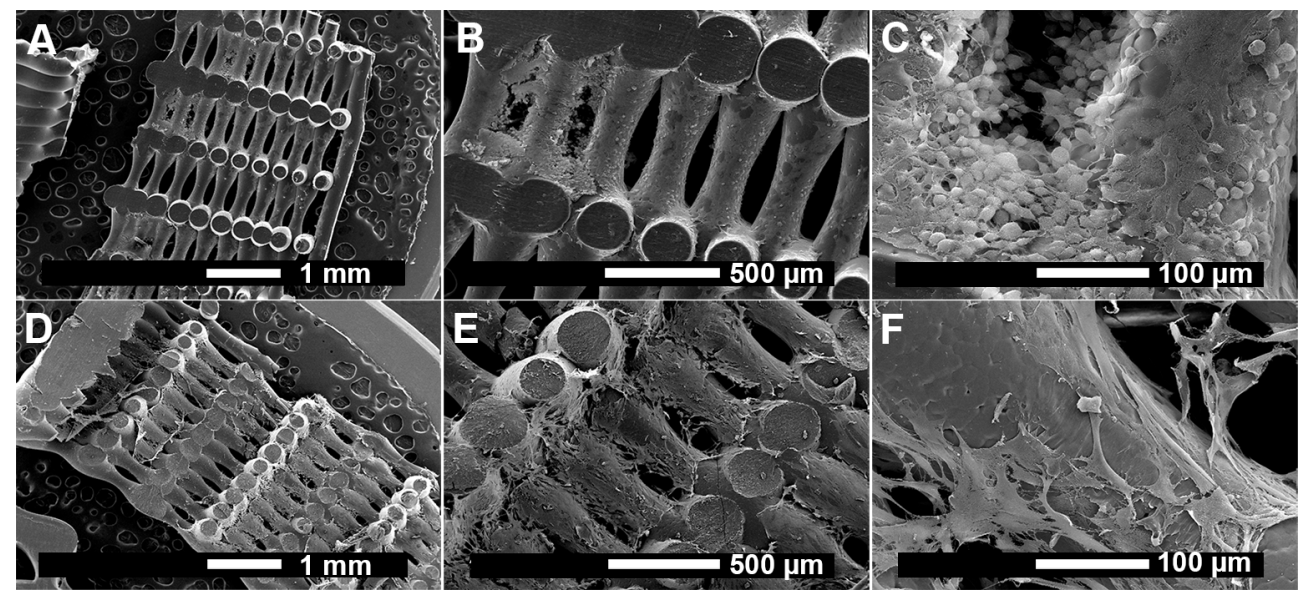

Figure S4.2: Scanning electron microscopy images of hfMSCs 6 hours (A-C) and 3 days (E-F) after seeding and culturing in static conditions. Scale bars represent (A, D) 1mm, (B, E) $500 \mu \mathrm{m},(\mathrm{C}, \mathrm{F}) 100 \mu \mathrm{m}$. 

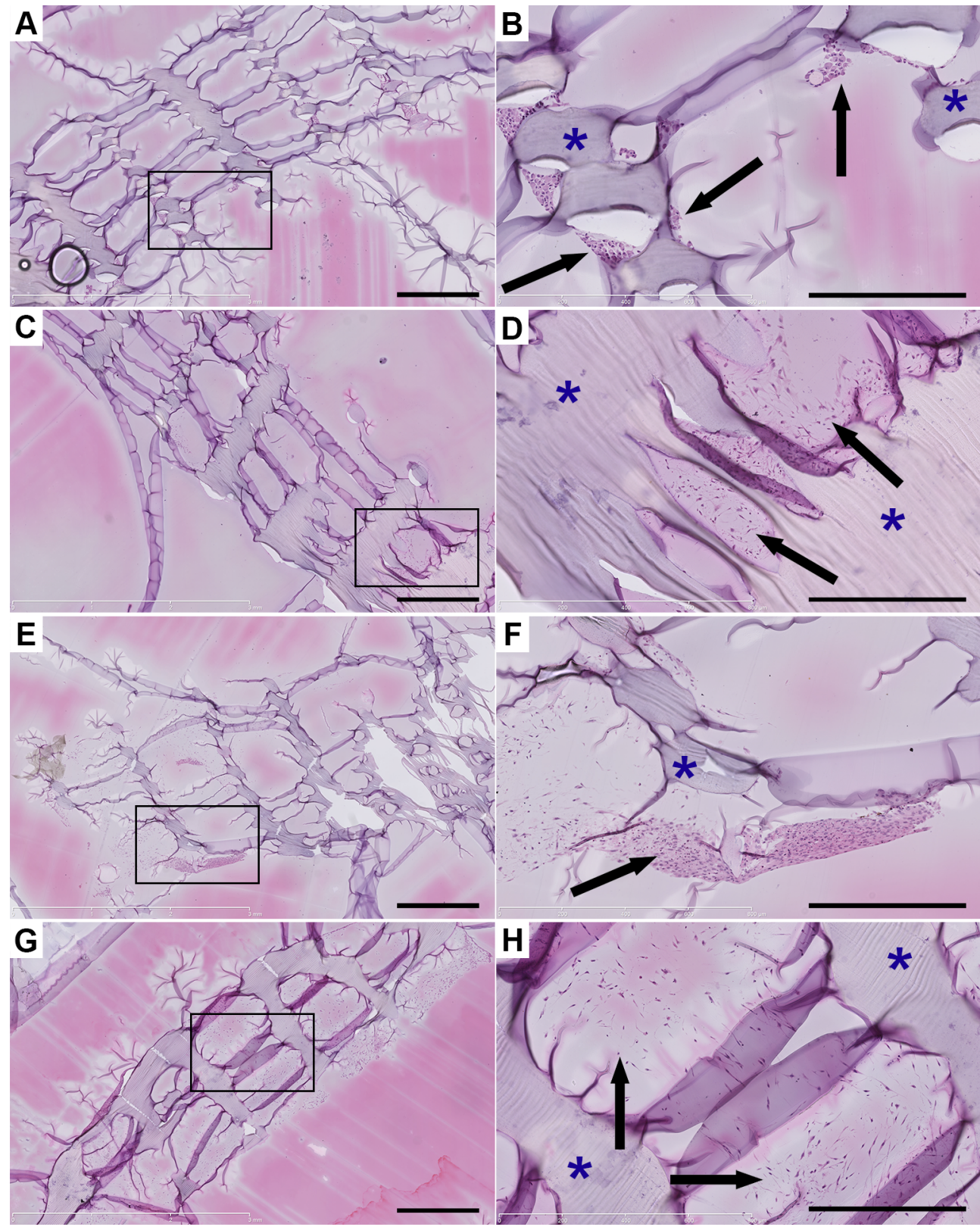

Figure S4.3: Hematoxylin and eosin staining were applied to assess hfMSCs distribution throughout the scaffold after 6 hours $(\mathrm{A}, \mathrm{B}), 3$ days $(\mathrm{C}, \mathrm{D})$ and 9 days $(\mathrm{E}, \mathrm{F})$ of static culture and after 3 days of static followed by 6 days of dynamic culture in a biaxial rotating bioreactor $(\mathrm{G}, \mathrm{H})$. Arrows indicate cells, asterisks $\left(^{*}\right)$ indicate scaffold material. Scale bars represent (A, C, E, G) 1mm, (B, D, F, H) $500 \mu \mathrm{m}$. 
A

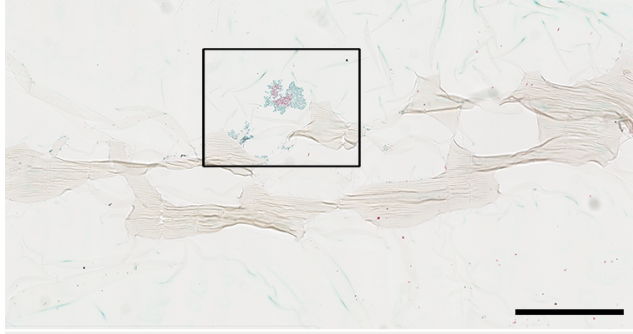

C

E
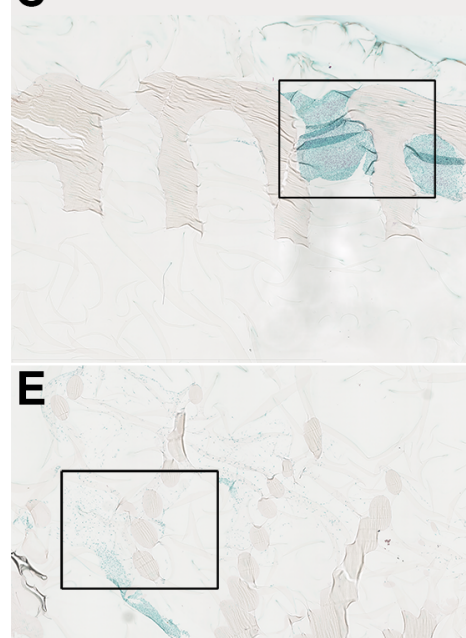

G
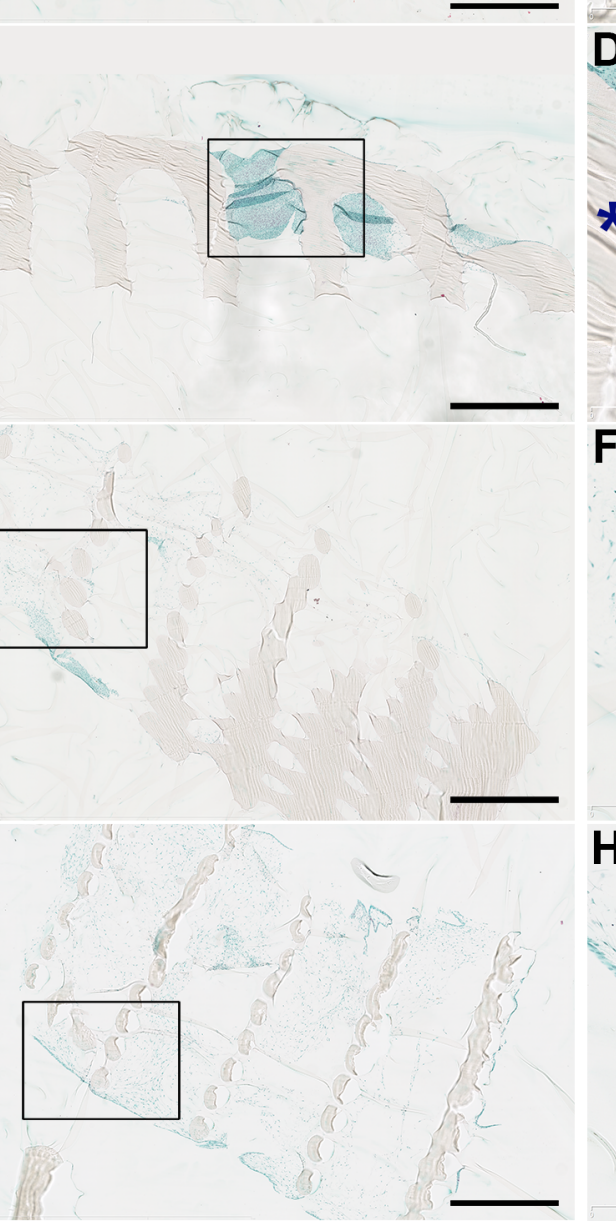

B

F
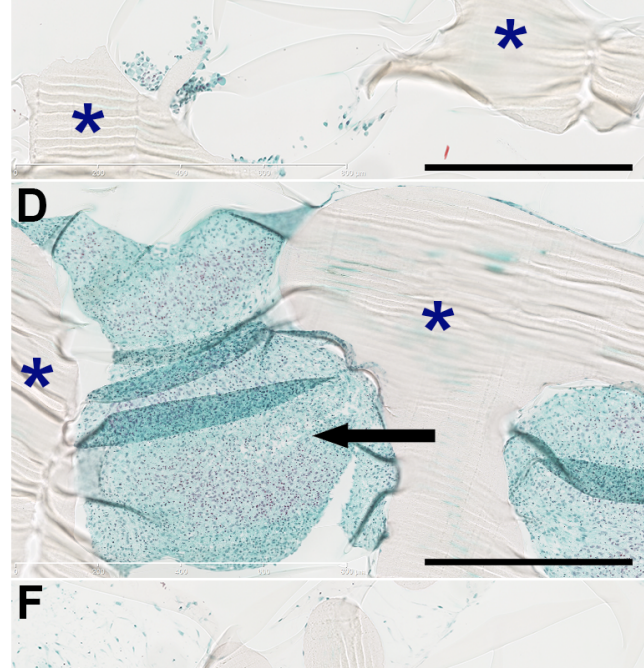


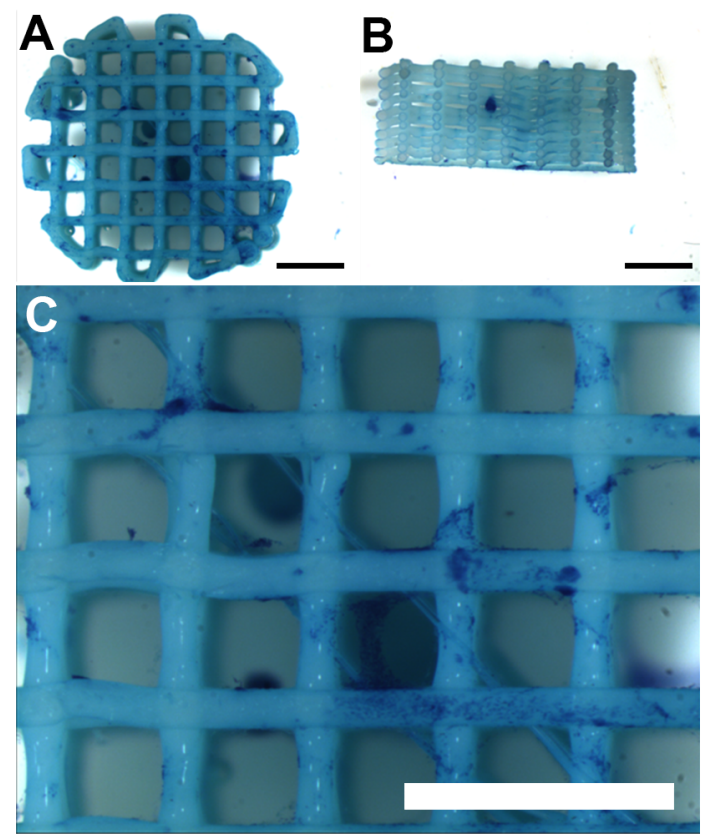

D

DNA quantification hMSCs

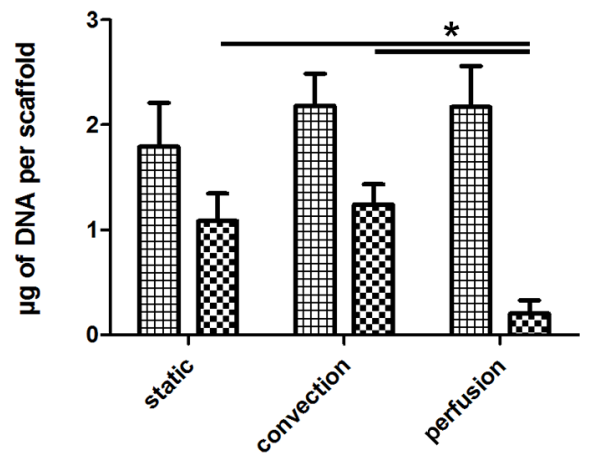

四 Donor 1

Ex Donor 2

Figure S4.5: Methylene blue staining of haMSCs (donor 2) after 3 days static followed by 6 days of dynamic culture in a perfusion bioreactor system (A-C) and the DNA quantification of haMSCs (D) $\left(\mathrm{n}=3,{ }^{*} \mathrm{p}<0.05\right)$. Scale bars represent $2 \mathrm{~mm}$. 
A

D
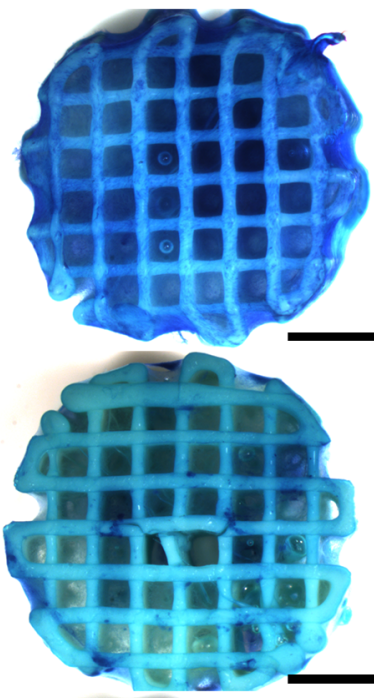

G

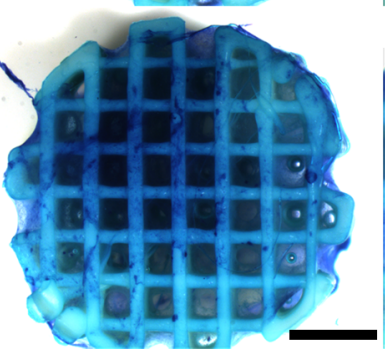

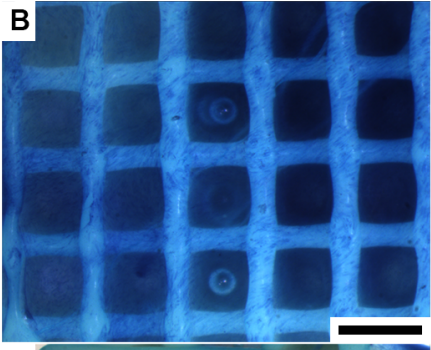
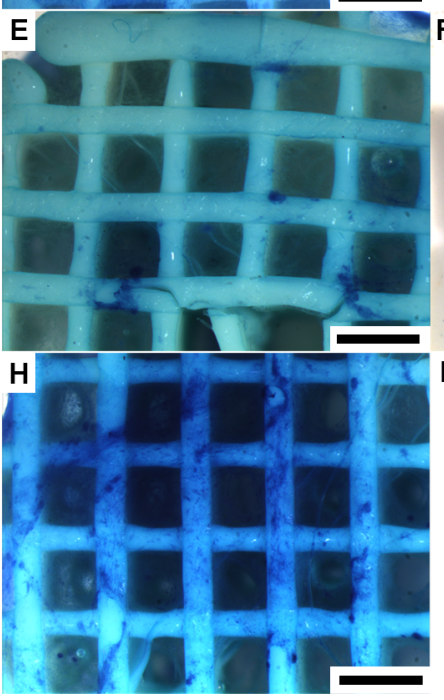

C

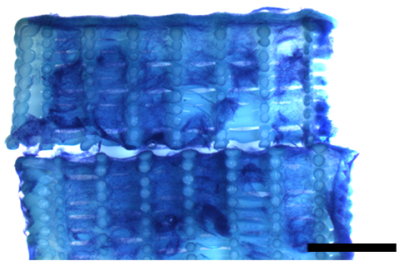

$F$
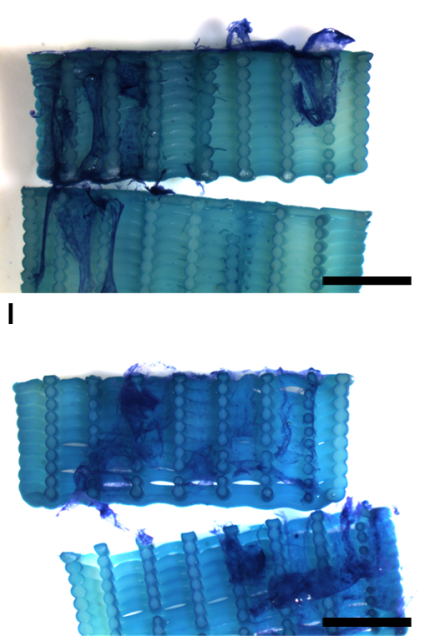

Figure S4.6: Methylene blue staining of donor 2 haMSCs after 31 days of static culture followed by another 14 days of static culture(A-C), 14 days of convection culture (D-F) or 14 days of perfusion culture (G-I). The highest number of cells with the most homogeneous cell distribution was found after static culture. It can be seen that the cell and tissue matrix was disturbed under the influence of convection and perfusion flow. In the cross-sectional view of the scaffolds (C, F, I) it can be seen that in dynamic conditions cell sheets were released from the scaffold whereas in static culture tissue and cells were maintained in the longitudinal pores of the scaffold. Scale bars represent (A, C, D, F, G, I) $2 \mathrm{~mm}$ and (B, E, H) $1 \mathrm{~mm}$. 


\section{DNA quantification haMSCs}

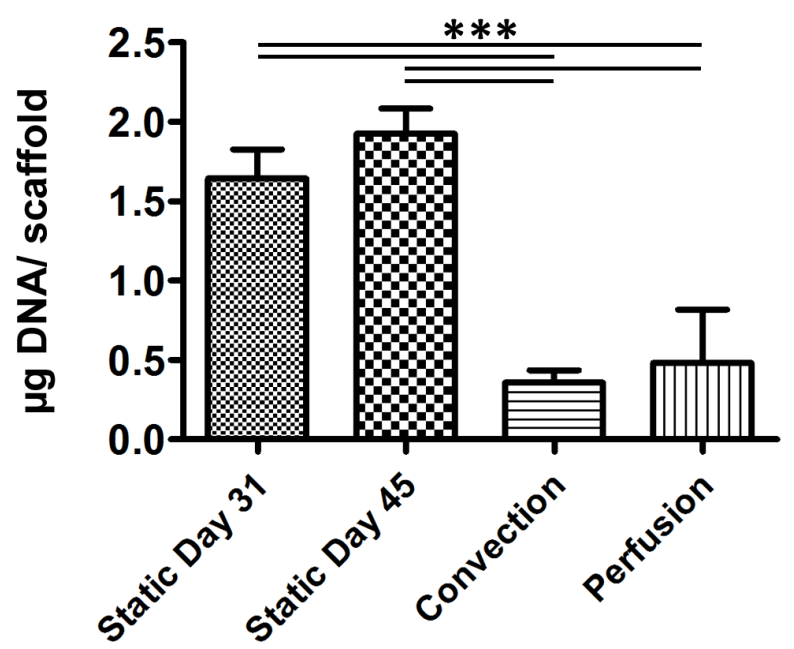

Figure S4.7: DNA quantification of donor 2 haMSCs after 31 days of static culture (day 31) and after 31 days of static culture followed by another 14 days of static culture (day 45), 14 days of convection culture or 14 days of perfusion culture. $(\mathrm{n}=3, * \mathrm{p}<0.05, * * \mathrm{p}<0.01$, $* * * \mathrm{p}<0.001)$ 


\section{Chapter 5}

\section{Engineered micro-objects as scaffolding elements in cellular building blocks for bottom-up tissue engineering approaches}

A. M. Leferink ${ }^{1}$, D. Schipper ${ }^{1}$, E. Arts ${ }^{1}$, E. Vrij ${ }^{1}$, N. Rivron ${ }^{1}$, M. Karperien ${ }^{1}$, K. Mittmann ${ }^{2}$, C. A. van Blitterswijk ${ }^{1}$, L. Moroni $^{1}$, R. K. Truckenmüller ${ }^{1}$

${ }^{1}$ Department of Tissue Regeneration of MIRA - Institute for Biomedical Technology and Technical Medicine, University of Twente, Drienerlolaan 5, 7522 NB Enschede, The Netherlands ${ }^{2}$ Fachbereich Physikalische Technik. Münster University of Applied Sciences, Germany 


\begin{abstract}
Conventional tissue engineering (TE) approaches are often based on the combination of autologous cells with a synthetic or biological material which serves as a mechanically stable three-dimensional (3D) environment to culture a artificial tissue construct in vitro prior to implantation. In most of these approaches, 3D scaffolds with distinct geometries and physicochemical properties are developed via top-down fabrication processes. To be able to culture cells on these scaffolds, several hurdles such as inhomogeneous cell distribution, limited nutrient diffusion and vascularization, and restricted remodelling capacity have to be overcome. Bottom-up TE aims to overcome these limitations by assembling individual building blocks in combination with cells before fabricating larger constructs. In this study, we let the cells self-assemble together with instructive engineered solid micro-objects into aggregates which can subsequently be fused into bigger geometrical units. Our method allows for the formation of complex 3D constructs by hierarchical assemblies of multiple cell and object types. Moreover, we show that the modulation of the objects properties such as their shape, size and wettability, in combination with variations of cell culture conditions and cell-to-object ratios, tailors the circularity, branching and compaction of the cell-driven assembly. This conveys to the new biofabrication platform proposed here an unprecedented degree of freedom in engineering instructive cell-material interactions, at the same time solving the drawbacks of current top-down and bottom-up approaches.
\end{abstract}

Keywords: Bottom-up tissue engineering, micro-objects, human bone marrow stromal cells, cell aggregates, biofabrication 


\subsection{Introduction}

In tissue engineering (TE) and regenerative medicine, directing or modulating cell behavior is known to be vital for the development of constructs to replace lost or damaged tissue [1]. In this study, we introduce a material-based bottom-up approach which allows to build up millimeter-sized geometrically shaped viable tissue constructs. With this new biofabrication platform, we show that it is possible to influence cell-material interactions and improve the distribution of viable cells throughout engineered tissues. By tailoring the physical and chemical properties of cell-adherent micro-objects functioning as scaffolding elements, the compaction and morphology of the formed tissue constructs can be modulated.

Conventional TE approaches are based on combining autologous cells with a synthetic or biological material which provides a mechanically stable three-dimensional (3D) environment to culture a substitute graft in vitro suited for implantation $[2,3]$. Therefore, tissue engineers and material scientists have been developing multitude of scaffold materials, with distinct geometries and physicochemical properties, and 3D culture methods. A great benefit of utilizing 3D scaffolds is the opportunity to create constructs of clinically relevant sizes and shapes. However, several hurdles with respect to cell culture on these scaffolds need to be overcome. These include inhomogeneous cell distribution, necrotic cores due to nutrient diffusion limitations and lack of vascularization, restricted remodelling capacity, and limited material-based control of cell fate due to limited accessibility of the scaffolds for surface modification or functionalization in 3D [4-7]. These drawbacks, to a bigger extent, originate from the static nature of the scaffolds' architectures.

Recently, bottom-up TE has been introduced to overcome these limitations. Bottom-up approaches have the potential to construct tissues with defined properties including spatial and temporal control at cellular level [8, 9]. Assembling individual building blocks allows for the fabrication of large complex tissue constructs. Currently, there are several bottom-up approaches under investigation from which the state-of-the-art was reviewed recently [9-12]. A first approach is based on scaffoldfree cultures where cells are aggregated into 3D tissue constructs [10, 13-18]. Baraniak and McDevitt reported that murine mesenchymal stromal cells (MSCs) cultured as spheroids in suspension without the use of a scaffold as a cell carrier preserve their multilineage potential better than murine MSCs cultured as a monolayer. In addition, our group showed that the fate of human MSCs (hMSCs) within large aggregates is determined by collectively generated actomyosin tension depending on the position of the cells within the aggregates. These scaffold-free aggregates tend to compact and round up, also when one tries to control the aggregate shape by culturing in correspondingly shaped wells. This compaction in scaffold-free approaches is not hindered by a material acting as a spacer, resulting in high numbers of cells required to obtain clinically relevant sized tissue constructs.

A second approach is based on gel-like materials and can overcome this problem of compaction by allowing the cells to reside in an extra cellular matrix (ECM) mimicking environment $[19,20]$. The use of hydrogels has shown a high potential in injectable systems to reduce in vivo the invasiveness of surgical procedures and to allow in vitro for controlled assembly achieving complex tissues. However, the lim- 

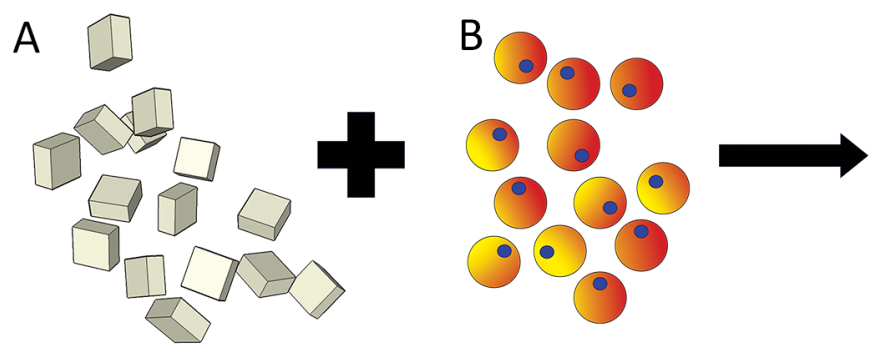

C

$\mathrm{F}$
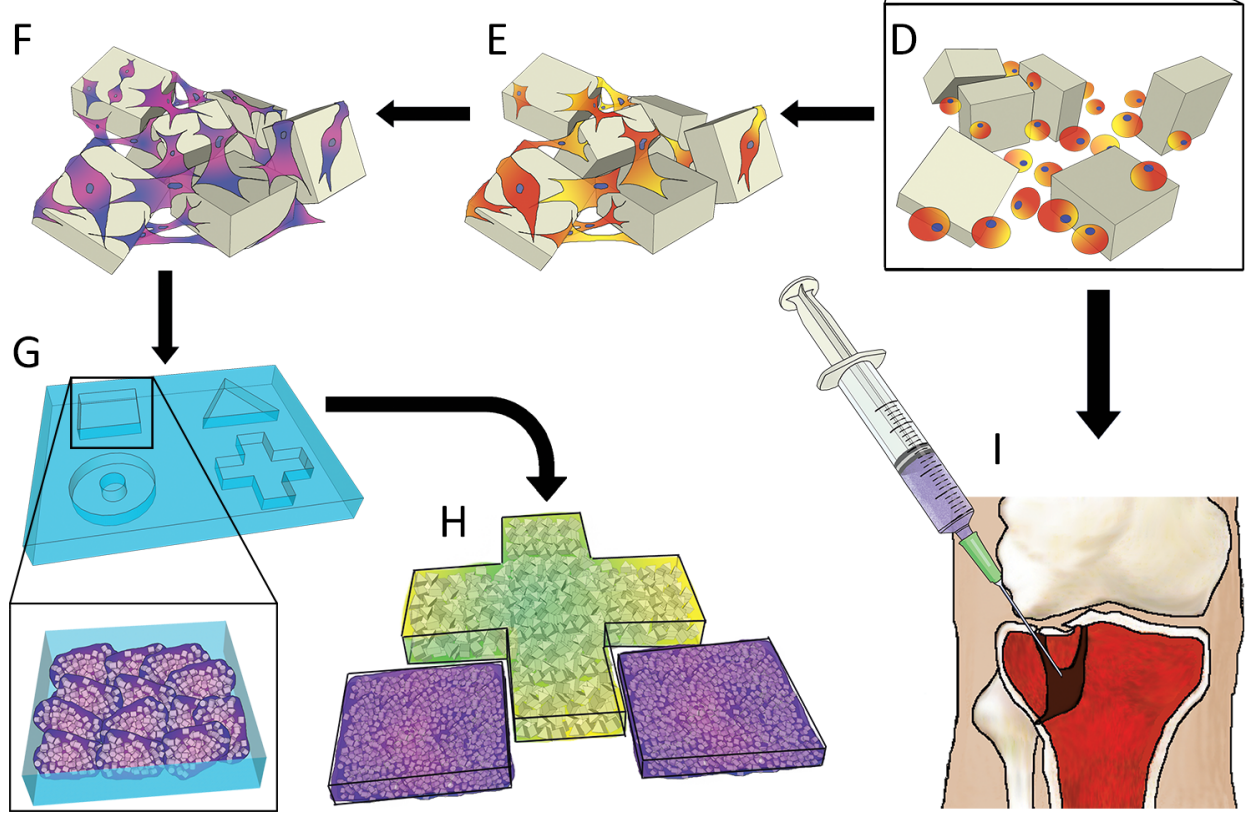

Figure 5.1: Schematic representation of bottom-up TE approach with microfabricated solid objects. (A) Micro-objects and (B) cells are cultured in (C) arrays of micro-wells to pre-aggregate. (D) Micro-objects directly after seeding. (E, F) Aggregate formation and cell fate (represented by a color change) can be influenced by the geometrical, mechanical, physical and chemical surface and bulk properties of the objects. $(G)$ After pre-aggregation, multiple micro-aggregates can be transferred and pooled into geometrically defined wells to fuse into larger sized tissue constructs. (H) Subsequently, constructs of different shapes and from various cell types can be combined to form controlled complex tissues. (I) A suspension of micro-objects and cells can be applied directly into a defect site where the objects act as a filler and as mechanical support, and ideally comprises instructive or inductive properties for the cells to grow and differentiate. 
itation of hydrogels is their limited load bearing capacity which makes them a less suitable material, for example, in hard tissue repair [21]. Moreover, hydrogels only allow diffusion of nutrients and gases, soluble factors and waste products which limits the size of constructs that can retain cells viability. This diffusion limit often results in the cells residing on the extremes of the hydrogel where the access to oxygen is better, therewith decreasing the homogeneity of the cellular distribution [22]. A third drawback of using hydrogels is related to their processing. Most cell-laden hydrogels opted for use in TE approaches are processed by crosslinking of cell-containing precursors with the aid of potentially toxic or denaturizing crosslinking agents. This process is known to create or represent an unfavorable, chemically reactive (free radicals) and toxic microenvironment for the cells also including harmful ionizing UV-light and or elevated temperatures [23].

In contrast to encapsulating cells in hydrogel structures, we propose a materialbased bottom-up approach in which we let the cells self-assemble together with instructive engineered solid micro-objects into (shaped) aggregates which then can be fused into bigger geometrical units. We hypothesize that our method allows for the formation of complex 3D constructs by hierarchical assemblies of multiple cell and object types. Cell seeding on these individual micro-objects showed to retain cell viability and considerably improve cellular distribution compared to conventional 3D scaffolds. Moreover, we also show that the modulation of the objects properties such as their shape, size and wettability, in combination with variations of cell culture conditions and cell-to-object ratios, tailors the circularity, branching and compaction of the cell-driven assembly. This conveys to the new biofabrication platform proposed here an unprecedented degree of freedom in engineering instructive cell-material interactions, at the same time solving the drawbacks of current top-down and bottom-up approaches. The micro-objects in our strategy can function as carriers for cell delivery or as cell-assembled scaffolds for tissue constructs of clinically relevant sizes as shown in Figure 5.1. Other applications could be found in those fields working with complex 3D tissues such as stem cell research, cancer research, developmental biology, bioartificial organs, pharmaceutical drug testing or toxicity testing.

\subsection{Results and Discussion}

As in the first instance we want to show the concept of our bottom-up approach, the micro-objects were simply fabricated by direct lithography from the photocurable epoxy-resin SU-8 (Microchem) just as a model material. This material is not used to replace tissues, but it has a multiple-documented biocompatibility and is used in various biomedical microdevices, also in vivo [24-28]. We proved however that similar micro-objects in principle can be also fabricated from an established thermoplastic and photoinitiator-free bio(degradable) polymer such as poly-DL-lactic acid by an advanced process based on thermal micro- or nanoimprint lithography on a water-soluble sacrifical layer. The SU-8 objects were released from the wafer on which they were fabricated by dissolving a sacrificial layer in this case from OmniCoat ${ }^{\mathrm{TM}}$ (Microchem) in N-methyl-2-pyrrolidone (NMP) (Figure S5.1 in the Supporting information). To increase the hydrophilicity of the objects, still on the wafer, they were treated in an oxygen plasma. To render some objects even more hydrophilic, a chemical etch in 


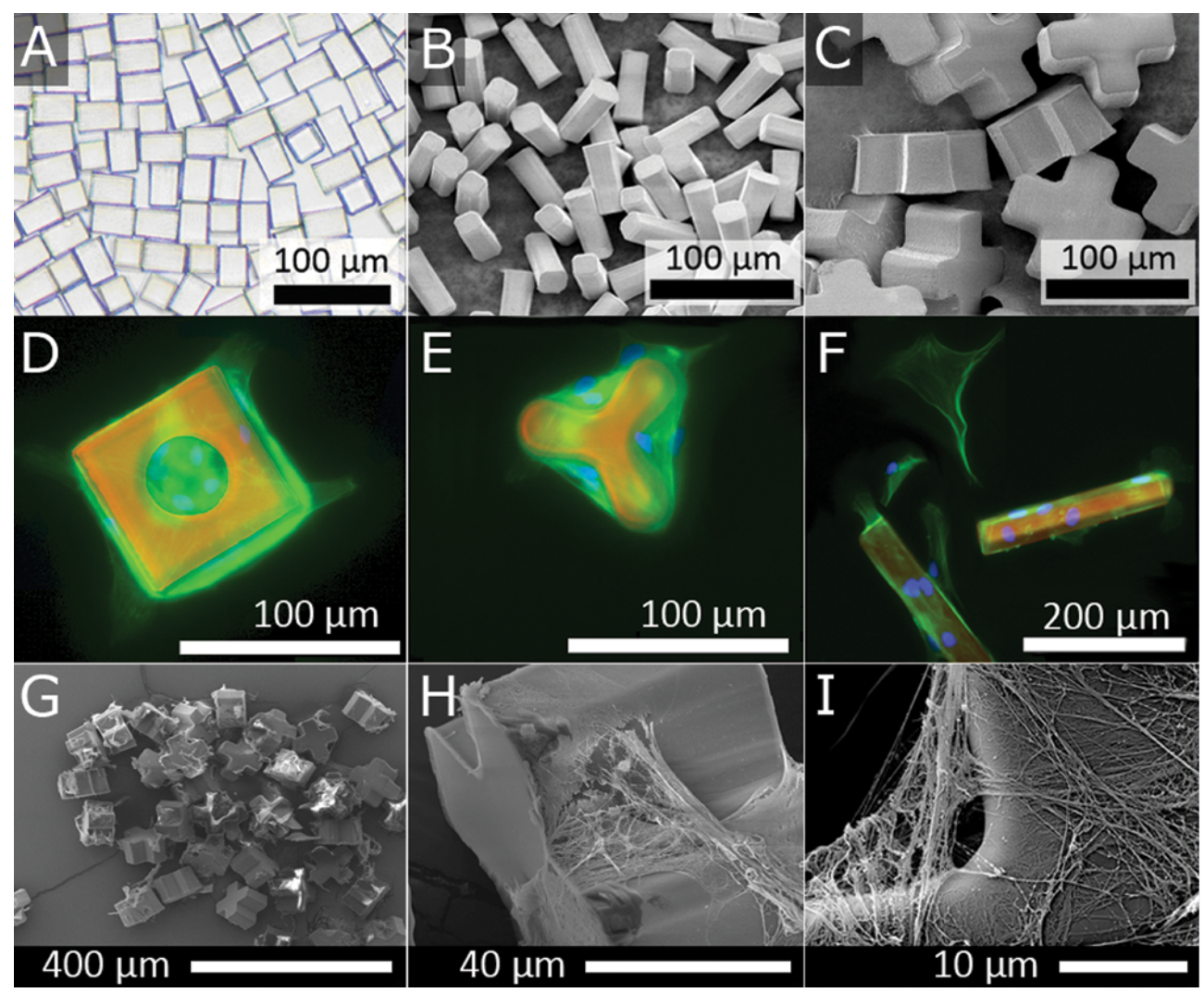

Figure 5.2: (A) Small-sized $\left(20 \times 20 \times 40 \mu \mathrm{m}^{3}\right)$ micro-objects are successfully released from the wafer by dissolving the OmniCoat ${ }^{\mathrm{TM}}$ sacrificial layer after fabrication. (B, C) Scanning electron microscopy (SEM) images show that objects with distinct geometries were successfully fabricated and released from the substrate wafer. (D-F) When culturing iMSCs on oxygen-treated SU-8 micro-objects, a DAPI (nuclei, blue) and Phalloidin (cytoskeleton, green) staining shows that multiple cells adhere to single objects (adapted from bright field image, red), thereby even bridging between the extremeties or residing in a hole of an object. (G-I) SEM images show that hMSCs adhere to multiple cross-shaped objects. The cells bridge between the objects and produce a high amount of ECM-like material.

sulfuric acid was carried out. The wettability of the material upon the oxygen and sulfuric acid treatment was determined by contact angle measurements and protein adsorption tests (fluorescein-labeled bovine serum albumin, BSA) (Table S1 in the Supporting information).

After successful release from the wafer, a suspension of micro-objects (Figure 5.2A) can be handled like a cell suspension, meaning that objects can be centrifuged, counted or even introduced in a flow cytometer. Prior to cell culture, the objects were washed extensively in deionized (DI-)water and subsequently in $70 \%$ ethanol to remove traces of NMP and to sterilize, respectively. The objects have a defined shape which stays intact throughout the releasing and sterilization processes (Figure 5.2B 
and $\mathrm{C}$ ). For cell culture experiments, a murine myoblast cell line (C2C12), a murine pre-chondrogenic cell line (ATDC5), immortalized MSCs (iMSCs),[29] and hMSCs were used.

After combining a relative low number of oxygen-plasma-treated micro-objects with iMSCs or $\mathrm{C} 2 \mathrm{C} 12$ cells on a non-tissue-culture-treated polystyrene plate, cells were found to attach to the SU-8 objects within 24 hours of culture (Figure 5.2D-F). DAPI/Phalloidin staining shows the nuclei and cytoskeletons of multiple iMSCs adhering to individual objects. Cells were able to bridge a hole in an object (Figure $5.2 \mathrm{D}$ ) or bridge between the extremities of an object (Figure 5.2E). A similar behavior was found for $\mathrm{C} 2 \mathrm{C} 12$ cells. Figure $5.2 \mathrm{G}$ and $\mathrm{H}$ show that the iMSCs adhere to the objects and spread over the objects surface. At higher magnification (Figure 5.2I), it can be clearly seen that the cells produce ECM on the material surface, which suggests that the cells are highly metabolically active. These results show that the observed cell-material interactions are promising for further studies on the applicability of the objects as potential cell supporting structures. Therefore, the experiments were upscaled to higher number of cells and objects per well to study cell-material interactions at larger scale.

The number of objects that were assembled into aggregates and the compaction of these aggregates were monitored for two sizes of cube-shaped objects (medium (M): $40 \times 40 \times 40 \mu \mathrm{m}^{3}$, large (L): $80 \times 80 \times 40 \mu \mathrm{m}^{3}$ ) (medium cube-shaped objects in Figure 5.2A) and one size of large cross-shaped objects $\left(90 \times 90 \times 40 \mu \mathrm{m}^{3}\right.$; Figure $\left.5.2 \mathrm{C}\right)$ at several timepoints. The volume of a cross-shaped object in these experiments corresponded to the volume of a large cube. Figure 5.3 shows how fast the cells and objects form aggregates. By changing the cell-to-structure ratio, the culture conditions, the wettability, and the size and shape of the objects, the density of the formed aggregates can be controlled. Figure S5.2 shows the quantification of the aggregation behavior of the objects and the cells by determining the percentage of the total number of objects which was incorporated in an aggregate. When the objects were incubated in cell culture medium without the presence of cells, no aggregation was observed, even after several weeks. The relative number of aggregated objects was lower on sulfuric-acid-treated objects than on oxygen-plasma-treated structures when a low number of cells (500 cells per well) was seeded. Furthermore, it was found that the relative number of aggregated objects is lower for $\mathrm{C} 2 \mathrm{C} 12$ cells compared to iMSCs. iMSCs are known to spread in culture, whereas $\mathrm{C} 2 \mathrm{C} 12$ cells show a smaller, spindle-like morphology. This difference in morphology could lead to iMSCs being able to cover more object surface area and can therewith also spread over multiple objects.

Significant differences were also found in the shape of the formed aggregates described by the circularity, which is given by a function of the perimeter $\mathrm{P}$ and the area A of a projection of the aggregate (Equation S1 in Supporting information). A higher aspect ratio (variance in the diameter of the aggregate) or degree of branching of the aggregate results in a lower circularity. A significant difference $(p<0.001)$ in circularity depending on the cell type was observed in five out of six conditions where iMSCs showed a higher circularity than $\mathrm{C} 2 \mathrm{C} 12$ cells (Figure S5.3). Only for sulfuric-acid-treated crosses, no significant difference was found. This difference in aggregation behavior between cell types could, just like the relative number of ob- 
jects in an aggregate, be explained by the morphology of the cells. Due to the spread morphology of iMSCs compared to $\mathrm{C} 2 \mathrm{C} 12$ cells, actomyosin forces could be carried out on more objects per cell in the case of iMSCs. iMSCs were also found to produce a lot of ECM which also could have promoted fast aggregation and remodelling.

With respect to the influence of the treatment of the objects, four out of six conditions showed a significantly higher circularity for oxygen-plasma-treated objects compared to sulfuric-acid-treated objects. This result suggests that oxygen plasma treatment not only results in a more suitable hydrophilicity for cell adherence but also allows cells to a higher extent to spread and adhere to multiple objects which induces remodelling and compaction of the aggregate possibly by actomyosin forces. Other parameters that could have an influence on circularity are the shape and size of the objects [21]. With respect to the shape of the structures, cubes were expected to show higher circularity than crosses due to their more compact geometry. However, differences were found only for sulfuric-acid-treated objects seeded with iMSCs where large cubes showed a significantly higher circularity than the large cross-shaped objects. Structure size was also expected to play a role in the compactness of the aggregate, where large micro-objects were expected to result in less circular aggregates than smaller ones. Though, for this parameter, no significant differences were found in any of the conditions. This could be caused by the fact that the size and shape of the objects was only altered in $2 \mathrm{D}$, whereas the third dimension (the thickness of the SU-8 layer in the fabrication process) stayed constant at $40 \mu \mathrm{m}$.

When a low number of cells was combined with large micro-objects on a flat layer of $1 \%$ agarose (Figure 5.3B), the geometry of the aggregate was very distinct from the aggregates formed on a hemispherical layer of $1 \%$ agarose (Figure 5.3A). This suggests that the compactness and circularity of the aggregates is not solely cellguided, but can also be modulated by the culture conditions (Figure S5.4A-D). Other potential approaches to control the density and complexity of the aggregates could for example be the design of objects having a high aspect ratio or asymmetry, which could inhibit the compaction sterically, or by partial functionalizion of the objects to create amphiphilic elements or to introduce a so-called 'DNA glue' for directing the mesoscale assembly [30].

To investigate whether these aggregates can be monitored with respect to cell viability, morphology and tissue growth, and to increase the clinical relevance, further experiments were carried out using oxygen-plasma-treated objects combined with hMSCs. Life/dead staining showed a high cell viability (>95\%) after 4 days (Figure $5.3 \mathrm{C}$ ) of culture which was confirmed by flow cytometry on various shapes of SU8 objects (Figure S5.5). It was also found that the cells distribute homogeneously throughout the aggregate and can fuse several small aggregates into a larger sized aggregate (Figure 5.3D and S6). The viability of large aggregates of objects and cells (initially 10,000 objects and 50,000 hMSCs) and of aggregates consisting of hMSCs only was assessed after 11 days of culture and compared (Figure S5.7).

The positive results on cell proliferation found by DNA quantification (Figure S5.8) and the high cell viability shown in Figure 5.3C, S5.5 and S5.7, make the microobjects promising candidates as 3D cell carriers for up-scaling expansion cultures. Furthermore, the objects have large potential as filler material since the volume of the obtained tissue constructs showed to be much larger compared to cell-only cultures 


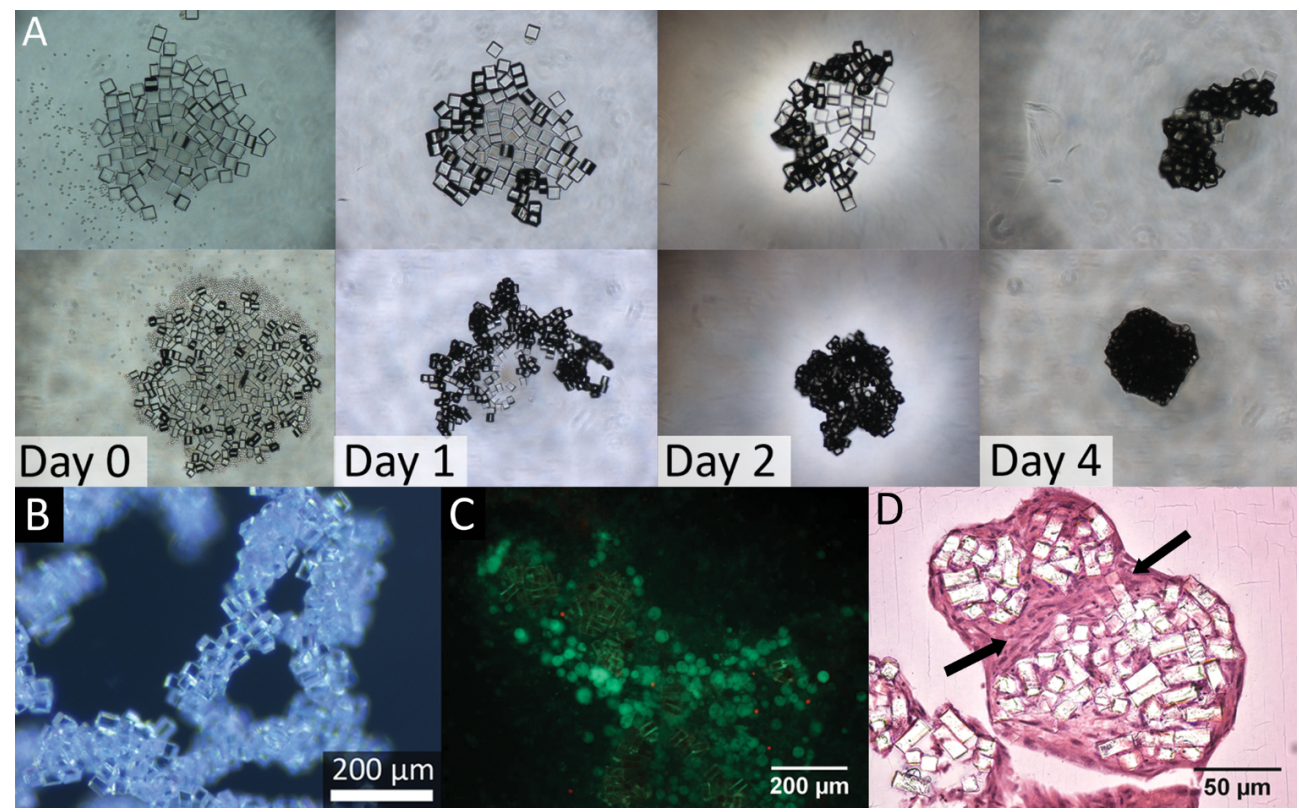

Figure 5.3: (A) Two time sequences of iMSCs cultured with cube-shaped objects of different sizes (first row: large $=80 \times 80 \times 40 \mu \mathrm{m}^{3}$; second row: medium $=40 \times 40 \times 40 \mu \mathrm{m}^{3}$ ) on a hemispherical layer of $1 \%$ agarose are shown. The sum of the objects' volumes was adjusted to be the same for both sequences. It can be seen that the smaller objects show comparatively high compaction within 4 days, resulting in a round aggregate, whereas the larger objects inhibit the remodelling of the aggregate, resulting in a compact, but not complete circular aggregate. (B) After 4 days of culturing, a low number of cells combined with large microobjects $\left(80 \times 80 \times 40 \mu \mathrm{m}^{3}\right)$ on a flat layer of $1 \%$ agarose, a branched open network of cells and objects is found. It can be clearly seen that the geometry of the aggregate is very distinct from the aggregates formed on a hemispherical layer of $1 \%$ agarose. (C) A calcein/etidium homodimer staining shows that most cells are alive (green) after 7 days of culture, just a few $(<5 \%)$ dead cells (red) are found for hMSCs cultured with multiple object types. (D) Hematoxilin and eosin staining confirms a homogenous cell distribution within aggregates and shows bridging of the cells between the aggregates (indicated by arrows). 
without micro-objects (Figure S5.9).

To further show that the cells continuously remodel the aggregates, three spherical aggregates were brought into one well after 7 days of culture. The aggregates clearly merged into one larger-sized aggregate within 4 days (Figure 5.4A) as already found by histological analysis (Figure 5.3D). To study migration of cells from one aggregate to another after fusion, cells were pre-stained with fluorescent dyes (Di-I and DiO). The fluorescently labelled cells were seeded separately with the micro-objects to form red or green stained aggregates. Cells did not only bridge the aggregates, but migrated from one aggregate to another upon fusion (Figure S5.10A and B). As a proof of concept for engineered larger-sized tissue constructs with controlled geometry, chondrogenic ATDC5 cells and objects were pre-aggregated into spherical aggregates in $400 \mu \mathrm{m}$ diameter microwells (Figure 5.4B). After 4 days of pre-aggregation, the micro-aggregates were flushed out of the microwells (Figure $5.4 \mathrm{C}$ ) and successfully fused into larger geometric aggregates in millimetre-sized wells (Figure 5.4D). After 10 days of allowing the aggregates to fuse into millimetre-sized toroids, these toroids were stacked to form a stable trachea-shaped tubular structure within 5 days after stacking (Figure 5.4E and $\mathrm{F}$ ).

Histological analysis of this toroidal tissue construct again showed high number of cells homogeneously distributed between the objects without indications of necrosis (Figure S5.11). One can imagine that this same approach could be applied for the development of vessel-like constructs when using vascular endothelial cells or for defect-shaped bone fillers when using osteoblast precursors, among other applications.

To overcome the limitations of cell-based or gel-based bottom-up approaches with respect to mechanical stability, the micro-objects could function as an enforcing material introducing more mechanical stability in for example cellular aggregates or in hydrogel approaches (Supporting data Table S2 and S3)[31, 32]. To show the potential of our objects to be used in an injectable system as presented in Figure 5.1, several injectability tests were performed. The following conditions were assessed, hMSCs with objects in culture medium, cell-object-aggregates in culture medium and cell-objectaggregates in an alginate solution which was crosslinked directly after extrusion (video available upon request). The viability of the injected cells was assessed qualitatively 6 hours after extrusion through a 18G needle by a live/dead staining (Figure S5.7 E and $\mathrm{F}$ ).

To overcome possible nutrient deficiency when upscaling the size of the assembled tissue constructs towards the sub-cm or cm-range, the objects could for example be designed with a high asymmetry or high aspect ratio features which could sterically limit compaction introducing cavities and channels through which medium can be perfused. Another approach is to already enable vascularisation in the early stage of culture in vitro by culturing the cells and objects on top of a vascular bed as presented by Sekine et al. [33].

\subsection{Conclusions}

In summary, this study showed how shape, size and wettability of engineered microobjects can play an important role when cells are allowed to assemble with these objects. The main difference between our approach and cell-only or hydrogel-based 


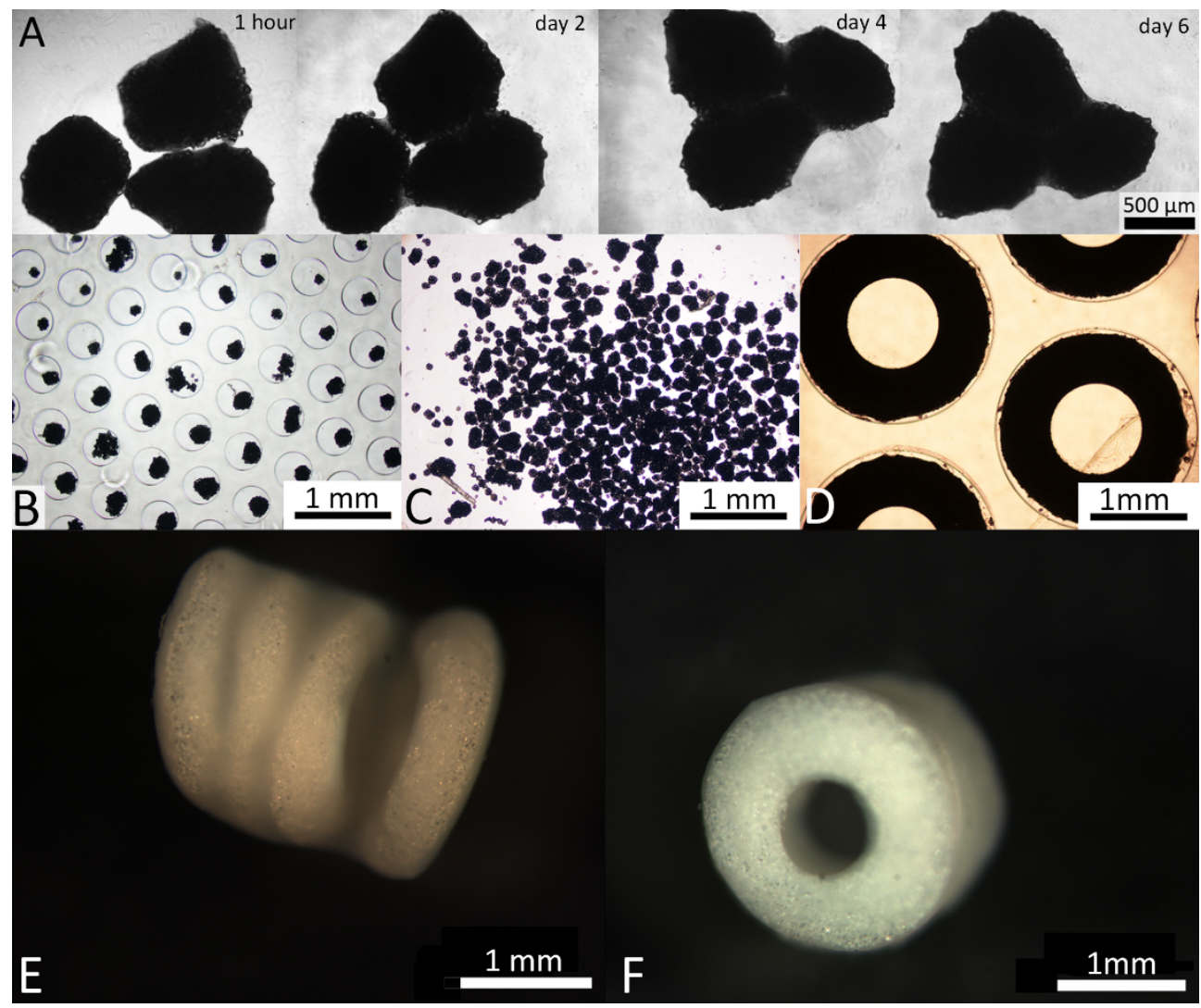

Figure 5.4: (A) After 7 days of aggregation on a hemispherical layer of $1 \%$ agarose, three aggregates were brougth into close vicinity into one well. Within 4 days, the aggregates fused due to cells bridging and migrating from one aggregate to another. (B) Cells and objects are pre-aggregated in agarose microwells with a diameter of $400 \mu \mathrm{m}$. (C) After 4 days, stable and compact aggregates can be flushed out of the wells and transferred to larger-sized, geometrically shaped agarose wells. (D) Toroidal tissue constructs are formed within 4 days of culture which can subsequently be stacked on a needle to form (E, F) stable tubular structures within another 4 days. 
bottom-up approaches can be found in the role of the cells in assembling macro-sized tissue constructs[15, 19, 30,34]. The approach presented here allows the cells to bind to a substrate material allowing cell-cell contact which could be beneficial for certain cell-types and applications. A layer of cells will be present at the surface of the aggregates which allows them to interact directly with other aggregates when brought into contact, whereas in hydrogels all cells reside within the hydrogel matrix. Combining cells and micro-objects at the microscale prior to assembling at the mesoscale enables a certain degree of control over tissue complexity since several cell-types and various types of micro-objects can be introduced in an early stage. Our approach shows how relatively low number of cells are required to obtain large mm-sized viable tissue constructs compared to cell-only approaches. Moreover, the cells are able to actively assemble and remodel these aggregates, whereas in hydrogel based bottomup TE other approaches such as DNA-glue have to be introduced to direct mesoscale assemblies. By modulating cell attachment sites on the micro-objects, higher control on aggregate parameters such as aggregation rate and compactness could be achieved.

Further development of the bottom-up approach presented in this study will be focused on characterization of cell-material interactions in combination with microobjects fabricated from biocompatible, implantable materials such as polylactide, polytrimethylene carbonate or copolymers of polyethylene oxide terephthalate and polybutylene terephthalate. Subsequently, a major step towards the design of a system in which cell fate and tissue shape as well as tissue complexity can be controlled will be the investigation of the influence of -among others - object size, shape, stiffness and surface chemistry or topography on cellular phenotype.

Ultimately, this approach could not only be used as a tool to engineer complex 3D tissues of clinically relevant size, but it could also find its application in the clinic for example as injectable system [21], or in the pharmaceutical industry as a 3D model to study tissue pathology and discover potentially new drugs.

\section{Acknowledgements}

The authors gratefully acknowledge the funding from the Netherlands Institute for Regenerative Medicine (NIRM) through the grant number FES0908. The authors would like to acknowledge Gerard Cadafalch Gazquez for assistance on the AFM analysis and Roy Visser for assistance in rheological tests. 


\section{References}

[1] Wu EC, Zhang SG, Hauser CAE. Self-Assembling Peptides as Cell-Interactive Scaffolds. Advanced Functional Materials. 2012;22:456-68.

[2] Elisseeff J, Ferran A, Hwang S, Varghese S, Zhang Z. The role of biomaterials in stem cell differentiation: Applications in the musculoskeletal system. Stem Cells and Development. 2006;15:295-303.

[3] Vacanti JP, Langer R. Tissue engineering: the design and fabrication of living replacement devices for surgical reconstruction and transplantation. Lancet. 1999;354:Si32-Si4.

[4] Solchaga LA, Tognana E, Penick K, Baskaran H, Goldberg VM, Caplan AI, et al. A rapid seeding technique for the assembly of large cell/scaffold composite constructs. Tissue Eng. 2006;12:1851-63.

[5] Harrison BS, Eberli D, Lee SJ, Atala A, Yoo JJ. Oxygen producing biomaterials for tissue regeneration. Biomaterials. 2007;28:4628-34.

[6] Domaschke H, Gelinsky M, Burmeister B, Fleig R, Hanke T, Reinstorf A, et al. In vitro ossification and remodeling of mineralized collagen I scaffolds. Tissue Eng. 2006;12:949-58.

[7] Kumar G, Tison CK, Chatterjee K, Pine PS, McDaniel JH, Salit ML, et al. The determination of stem cell fate by $3 \mathrm{D}$ scaffold structures through the control of cell shape. Biomaterials. 2011;32:9188-96.

[8] Causa F, Netti PA, Ambrosio L. A multi-functional scaffold for tissue regeneration: The need to engineer a tissue analogue. Biomaterials. 2007;28:5093-9.

[9] Elbert DL. Bottom-up tissue engineering. Curr Opin Biotech. 2011;22:674-80.

[10] Rivron NC, Rouwkema J, Truckenmuller R, Karperien M, De Boer J, Van Blitterswijk CA. Tissue assembly and organization: Developmental mechanisms in microfabricated tissues. Biomaterials. 2009;30:4851-8.

[11] Nichol JW, Khademhosseini A. Modular tissue engineering: engineering biological tissues from the bottom up. Soft Matter. 2009;5:1312-9.

[12] Liu JS, Gartner ZJ. Directing the assembly of spatially organized multicomponent tissues from the bottom up. Trends in cell biology. 2012;22:683-91.

[13] Kelm JM, Djonov V, Ittner LM, Fluri D, Born W, Hoerstrup SP, et al. Design of custom-shaped vascularized tissues using microtissue spheroids as minimal building units. Tissue engineering. 2006;12:2151-60.

[14] Jakab K, Norotte C, Damon B, Marga F, Neagu A, Besch-Williford CL, et al. Tissue engineering by self-assembly of cells printed into topologically defined structures. Tissue engineering. 2008;14:413-21.

[15] Jakab K, Norotte C, Marga F, Murphy K, Vunjak-Novakovic G, Forgacs G. Tissue engineering by self-assembly and bio-printing of living cells. Biofabrication. 2010;2:022001.

[16] Baraniak PR, McDevitt TC. Scaffold-free culture of mesenchymal stem cell spheroids in suspension preserves multilineage potential. Cell Tissue Res. 2012;347:701-11.

[17] Langenbach F, Naujoks C, Smeets R, Berr K, Depprich R, Kubler N, et al. Scaffold-free microtissues: differences from monolayer cultures and their potential in bone tissue engineering. Clin Oral Invest. 2013;17:9-17.

[18] Masuda T, Takei N, Nakano T, Anada T, Suzuki O, Arai F. A microfabricated platform to form three-dimensional toroidal multicellular aggregate. Biomed Microdevices. 2012;14:1085-93.

[19] Yanagawa F, Kaji H, Jang YH, Bae H, Yanan D, Fukuda J, et al. Directed assembly of cell-laden microgels for building porous three-dimensional tissue constructs. Journal of biomedical materials research. 2011;97:93-102.

[20] Zorlutuna P, Annabi N, Camci-Unal G, Nikkhah M, Cha JM, Nichol JW, et al. Microfabricated biomaterials for engineering 3D tissues. Adv Mater. 2012;24:1782-804.

[21] Oliveira MB, Mano JF. Polymer-based microparticles in tissue engineering and regenerative medicine. Biotechnol Prog. 2011;4:897-912.

[22] Radisic M, Malda J, Epping E, Geng WL, Langer R, Vunjak-Novakovic G. Oxygen gradients 
correlate with cell density and cell viability in engineered cardiac tissue. Biotechnology and Bioengineering. 2006;93:332-43.

[23] Van Tomme SR, Storm G, Hennink WE. In situ gelling hydrogels for pharmaceutical and biomedical applications. Int J Pharm. 2008;355:1-18.

[24] Hennemeyer M, Walther F, Kerstan S, Schurzinger K, Gigler AM, Stark RW. Cell proliferation assays on plasma activated SU-8. Microelectron Eng. 2008;85:1298-301.

[25] Hassler C, Boretius T, Stieglitz T. Polymers for Neural Implants. J Polym Sci Pol Phys. 2011;49:18-33.

[26] Nemani KV, Moodie KL, Brennick JB, Su A, Gimi B. In vitro and in vivo evaluation of SU-8 biocompatibility. Materials science \& engineering C, Materials for biological applications. 2013;33:4453-9.

[27] Kotzar G, Freas M, Abel P, Fleischman A, Roy S, Zorman C, et al. Evaluation of MEMS materials of construction for implantable medical devices. Biomaterials. 2002;23:2737-50.

[28] Rubehn B, Wolff SB, Tovote P, Luthi A, Stieglitz T. A polymer-based neural microimplant for optogenetic applications: design and first in vivo study. Lab on a chip. 2013;13:579-88.

[29] Simonsen JL, Rosada C, Serakinci N, Justesen J, Stenderup K, Rattan SIS, et al. Telomerase expression extends the proliferative life-span and maintains the osteogenic potential of human bone marrow stromal cells. Nature Biotechnology. 2002;20:592-6.

[30] Qi H, Ghodousi M, Du Y, Grun C, Bae H, Yin P, et al. DNA-directed self-assembly of shape-controlled hydrogels. Nat Commun. 2013;4; DOI:10.1038/ncomms3275.

[31] Baraniak PR, Cooke MT, Saeed R, Kinney MA, Fridley KM, McDevitt TC. Stiffening of human mesenchymal stem cell spheroid microenvironments induced by incorporation of gelatin microparticles. J Mech Behav Biomed. 2012;11:63-71.

[32] Preziosi L, Ambrosi D, Verdier C. An elasto-visco-plastic model of cell aggregates. J Theor Biol. 2010;262:35-47.

[33] Sekine H, Shimizu T, Sakaguchi K, Dobashi I, Wada M, Yamato M, et al. In vitro fabrication of functional three-dimensional tissues with perfusable blood vessels. Nat Commun. 2013;4;DOI:10.1038/Ncomms2406.

[34] Eng G, Lee BW, Parsa H, Chin CD, Schneider J, Linkov G, et al. Assembly of complex cell microenvironments using geometrically docked hydrogel shapes. Proceedings of the National Academy of Sciences of the United States of America. 2013;110:4551-6.

[35] Both SK, Van der Muijsenberg AJC, Van Blitterswijk CA, De Boer J, De Bruijn JD. A rapid and efficient method for expansion of human mesenchymal stem cells. Tissue engineering. 2007;13:3-9.

[36] Hobolth A. The spherical deformation model. Biostatistics. 2003;4:583-95.

[37] Forgacs G, Foty RA, Shafrir Y, Steinberg MS. Viscoelastic properties of living embryonic tissues: a quantitative study. Biophysical Journal. 1998;74:2227-34.

[38] Necas D, Klapetek P. Gwyddion: an open-source software for SPM data analysis. Cent Eur J Phys. 2012;10:181-8.

[39] Malik WA, Prasad SC, Rajagopal KR, Preziosi L. On the modeling of the viscoelastic response of embryonic tissues. Math Mech Solids. 2008;13:81-91.

[40] Zhu Y, Dong Z, Wejinya UC, Jin S, Ye K. Determination of mechanical properties of soft tissue scaffolds by atomic force microscopy nanoindentation. Journal of biomechanics. 2011;44:2356-61. 


\section{Experimental Section}

\section{Micro-object fabrication}

The OmniCoat ${ }^{\mathrm{TM}}$ sacrificial layer was spin-coated on a 4 " silicon wafer followed by a $44 \pm 2 \mu \mathrm{m}$ layer of SU-8. Subsequently, the bilayered film was soft-baked using a programmed hotplate $\left(50{ }^{\circ} \mathrm{C}\right.$ for 10 minutes, $65{ }^{\circ} \mathrm{C}$ for 10 minutes, $95{ }^{\circ} \mathrm{C}$ for 20 minutes, cooling down back to $25{ }^{\circ} \mathrm{C}$ ). The micro-objects were obtained by exposing the photoresist (soft contact mode $30 \mu \mathrm{m}, 24$ seconds, $\mathrm{Hg}, 12 \mathrm{~mW} / \mathrm{cm}^{2}$, EVG 620 mask aligner, EV Group, Austria). To harden the photoresist, a post exposure bake was performed using a programmed hotplate $\left(50{ }^{\circ} \mathrm{C}\right.$ for 5 minutes, $65^{\circ} \mathrm{C}$ for 5 minutes, $80{ }^{\circ} \mathrm{C}$ for 10 minutes, slow cool down to $\left.25^{\circ} \mathrm{C}\right)$. The unexposed photoresist was removed by spray development for 6 minutes (Resist Edgebead Remover ${ }^{\mathrm{TM}} 600$, RER 600 , MicroChem). To increase the hydrophilicity of the structures, they were treated in an oxygen plasma $\left(50 \% \mathrm{O}_{2}\right)$ for 3 minutes at $600 \mathrm{~W}$ (TePla $300 \mathrm{E}$ plasma processor). The micro-objects were released from the wafer by dissolving the sacrificial layer with N-methyl-2-pyrrolidone (NMP). To render in some cases the objects even more hydrophilic, a chemical etch in $95 \%$ sulfuric acid was carried out at $80{ }^{\circ} \mathrm{C}$ for 10 seconds. The hydrophilicity of the material upon the oxygen plasma and sulfuric acid treatment was determined by performing contact angle measurements and protein adsorption tests (fluorescein-labeled BSA, Sigma). Prior to cell culture experiments, the objects were sterilized by immersion in $70 \%$ ethanol twice for 30 minutes, followed by washing three times in phosphate-buffered saline (PBS). Subsequently, the objects were incubated in $10 \%$ heat-inactivated fetal bovine serum (FBS, Lonza) containing culture media for at least $24 \mathrm{~h}$.

\section{Cell culture}

hMSC isolation and expansion was performed as previously described on human bone marrow aspirates obtained from donors after written informed consent [35]. iMSCs represent an immortalized clone retrieved after transducing hMSCs with the gene for the catalytic subunit of human telomerase (hTERT) (iMSCs, courtesy of Ola Myklebost, University of Oslo, Norway). hMSCs and iMSCs were cultured in a monolayer in proliferation medium consisting of alpha minimum essential medium (-MEM, Gibco) supplemented with L-glutamine (2 mM, Gibco), penicillin (100 U/mL, Gibco) and streptomycin (100 mg/mL, Gibco), FBS (10\% (w/v), Lonza), basic fibroblast growth factor $(1 \mathrm{ng} / \mathrm{mL}$, bFGF, Instruchemie) and ascorbic acid (0.2 mM, Sigma). C2C12 and ADTC5 cells were cultured in a monolayer in Dulbeccos Modified Eagle medium (DMEM, Gibco) supplemented with penicillin (100 U/mL, Gibco) and streptomycin (100 mg/mL, Gibco), and 10\% FBS ((w/v), Lonza) for $\mathrm{C} 2 \mathrm{C} 12$ cells and $5 \% \mathrm{FBS}$ for ADTC5 cells. Standard culturing conditions were $37{ }^{\circ} \mathrm{C}$ with a humidified $5 \%$ $\mathrm{CO}_{2} / 95 \%$ air atmosphere. Media were renewed every second (ATDC5) or third day (all other cell types). Cells were detached using trypsin $(0.25 \%(\mathrm{w} / \mathrm{v}))$ in ethylenediaminetetraacetic acid (EDTA) solution when a confluency of $7080 \%$ was reached. 


\section{Cell seeding on the micro-objects}

The concentration of micro-objects in medium after incubation was determined by counting the number of structures in $10 \mu \mathrm{l}$. Subsequently, a certain number of objects was added to the wells of the culture plates. Additionally, a specific number of cells was added within the same well. Mixing was applied by pipetting up and down shortly while adding medium up to the standard volume for that specific well.

\section{Quantification of aggregation behavior}

The number of structures incorporated within an aggregate was determined by counting the total number of structures in the well directly after seeding manually by image analysis. After 4 days of culture, the number of structures that was not incorporated within the aggregate was counted manually by image analysis. Circularity was calculated as a function of the perimeter $(\mathrm{P})$ and area $(\mathrm{A})$ of the aggregate measured by image analysis using the function 'measure'in ImageJ. The outline of the aggregate, corresponding to the perimeter, was drawn manually.

$$
\text { Circularity }=\frac{4 \pi A}{p^{2}} \times 100 \%
$$

\section{Viability staining}

To determine cell viability throughout the aggregates, a live/dead staining was performed. After washing the aggregates twice with PBS, they were incubated for 30 minutes with a $6 \mu \mathrm{M}$ ethidium homodimer (red fluorescent) $/ 1 \mu \mathrm{M}$ calcein (green fluorescent) mixture in PBS solution (LIVE/DEAD viability/cytotoxicity kit, Invitrogen/Molecular Probes) at room temperature (RT). Prior to imaging, aggregates were washed with PBS three times. Images were taken with a fluorescence microscope (Nikon Eclipse E600 and Nikon DS-Fi1c camera) using a Nikon Texas Red/FITC filter set.

\section{Histology}

Samples were dehydrated in increasing concentrations of ethanol (50, 60, 70, 80, 90, 96 and $100 \%(\mathrm{v} / \mathrm{v})$ ) for 30 minutes per step. Prior to embedding the samples into a twocomponent glycol methacrylate (GMA) (Merck) acrylic resin, the $100 \%$ ethanol was exchanged with $50 \%(\mathrm{v} / \mathrm{v})$ GMA-component A in ethanol and incubated over night $(\mathrm{o} / \mathrm{n})$ at $4{ }^{\circ} \mathrm{C}$. Additionally, the samples were immersed in 100\% GMA-A for 8 hours at $4{ }^{\circ} \mathrm{C}$. The samples were transferred to a Teflon $\cap$ mold and the two-component GMA was added and allowed to polymerize for 48 hours. Sections of $10 \mu \mathrm{m}$ thickness were obtained by cutting with a microtome (Microm HM355S, Thermo Scientific). Prior to staining, the sections were rehydrated in DI-water for 10 minutes. For the hematoxilin and eosin staining, Gills hematoxylin (Sigma-Aldrich) was applied for 30 minutes. After rinsing 3 minutes with tab water and additionally 3 minutes in DIwater, samples were counterstained with eosin for 6 minutes and dehydrated in $100 \%$ 
ethanol. The samples were dehydrated with ethanol, coverslips were mounted and imaging was carried out using a Nikon Eclipse E600 with a Nikon DS-Fi1c camera.

\section{Preparation and filling of microwell arrays}

Patterned chips from polydimethylsiloxane (PDMS) were placed in a 6 -well plate (NUNC). A heated agarose solution $(3 \%(\mathrm{w} / \mathrm{v})$, UltraPure agarose, Invitrogen) was casted on each PDMS chip. The agarose was allowed to solidify at $4{ }^{\circ} \mathrm{C}$. Subsequently, the molds were removed from the obtained agarose chips. Cylindrical pieces were punched out of the agarose chips and placed in 12-well plates. To fill the cylindrical microwells, objects were added in small amounts until all the wells were completely covered with structures. Additionally, a certain amount of cells was added, and a short centrifugation after mixing promoted the cells and objects to settle in the microwells.

\section{Statistical analysis}

All results were expressed as mean value and standard deviation (error bars). Statistical significance was tested by one-way analysis of variance (ANOVA) and Tukey's Multiple Comparison Test was carried out as post-hoc comparison using SPSS Statistics software (IBM). Statistical significance is indicated by $*, * *$ or $* * *$ corresponding to $\mathrm{p}<0.05, \mathrm{p}<0.01$ and $\mathrm{p}<0.001$, respectively. 


\section{Supplementary Information}

\section{Experimental}

\section{Methylene blue staining and imaging}

For methylene blue staining, the medium was aspirated carefully and aggregates were washed with pre-warmed PBS once. Afterwards, samples were incubated in $10 \%$ (v/v) formalin for 30 minutes at room temperature (RT) followed by gently washing in PBS. Each sample was immersed in about $100 \mu \mathrm{l}$ of a $1 \%(\mathrm{w} / \mathrm{v})$ methylene blue solution for 3060 seconds. After staining, the aggregates were washed extensively with DI-water until the water remained clear. Stained samples were visualized using a stereomicroscope (Nikon SMZ800 with QImaging Retiga 1300 camera).

\section{Flow Cytometry}

Flow cytometry was performed on samples up to 4 days in culture. Aggregates were disaggregated with trypsin. The suspension was pipetted up and down to loosen the aggregates and transferred to FACS tubes before centrifugation at $3000 \mathrm{rpm}$ for 3 minutes at $4{ }^{\circ} \mathrm{C}$. The supernatant was poured off and the tube was scratched over a ridged surface to re-suspend the pellet in the drop of remaining medium. Afterwards, $250 \mu \mathrm{L}$ FACS buffer and $10 \mu \mathrm{L}$ of 7 -AAD stain (Invitrogen) was added quickly before the samples were incubated for 5 minutes in dark. Cells were assessed by a BD Biosciences FACSCalibur ${ }^{\mathrm{TM}}$ flow cytometer and quantified by CellQuestß)software. Events were counted until the whole cell suspension was analyzed by the machine. In order to discriminate the microstructures from the cells, the cell counts were gated and the threshold was set between live and dead cells.

\section{Quantification of cell number by DNA assay}

The amount of DNA per sample (at different culture times of 3, 7 and 14 days) was used as an indicator for cell proliferation. The medium of the samples to be assessed was gently aspirated from the wells and aggregates were washed once in PBS. Samples were frozen at $30{ }^{\circ} \mathrm{C}$ for at least 24 hours. The samples were incubated for 16 hours at $56{ }^{\circ} \mathrm{C}$ with $1 \mathrm{mg} / \mathrm{mL}$ proteinase $\mathrm{K}$ (Sigma-Aldrich) in Tris/EDTA buffer ( $\mathrm{pH}$ 7.6) supplemented with $185 \mu \mathrm{g} / \mathrm{mL}$ iodoacetamine and $10 \mu \mathrm{g} / \mathrm{mL}$ pepstatin A (both Sigma-Aldrich). The culture plates were tightly sealed using Microseal B Adhesive Sealer MSB-1001 (Biorad) and incubated at $56{ }^{\circ} \mathrm{C}$ over night in a water bath. After incubation, $40 \mu \mathrm{L}$ of each digested sample was transferred to a white 96 -well plate and $40 \mu \mathrm{L}$ LBR solution containing lysis buffer and $\mathrm{NaCl}$ in EDTA (1:20) and RNase (1000:1) (Sigma-Aldrich) was added to each sample which was then incubated for 1 hour at RT. Quantification of total DNA was performed using the Cyquant ${ }^{\mathrm{TM}}$ DNA assay kit (Molecular Probes, Invitrogen). The fluorescence intensity of the incubated samples and DNA-standard was measured at 480/520 nm excitation/emission, respectively, using a fluorescent plate reader (Perkin Elmer). 


\section{Di-I/Di-O cell-labeling}

Vybrant ${ }^{\mathrm{TM}}$ CM-Di-I (red) and Di-O (green) cell-labeling solutions were purchased from Molecular Probes (Invitrogen). For labeling, the cells were trypsinized and $2^{*} 10^{6}$ cells were re-suspended in $1 \mathrm{~mL}$ PBS. $4 \mu \mathrm{L}$ of dye solution was added per $\mathrm{mL}$ of cell suspension, resulting in a concentration of $4 \mu \mathrm{M}$. The suspension was incubated for 5 minutes at $37^{\circ} \mathrm{C}$ before decreasing the incubation temperature to $4{ }^{\circ} \mathrm{C}$ for another 15 minutes to avoid endocytosis, while still labeling. Afterwards, the tube was filled up with PBS and the cells were centrifuged for 5 minutes at $300 \mathrm{~g}$. Finally, the pellet was re-suspended in proliferation medium before seeding.

\section{Histology}

Samples were dehydrated in increasing concentrations of ethanol $(50 \%, 60 \%, 70 \%$, $80 \%, 90 \%, 96 \%$ and $100 \%(\mathrm{v} / \mathrm{v}))$ for 30 minutes per step. Prior to embedding the samples into a two-component glycol methacrylate (GMA) (Merck) acrylic resin, the $100 \%$ ethanol was exchanged with $50 \%$ (v/v) GMA-component A in ethanol and incubated o/n at $4{ }^{\circ} \mathrm{C}$. Additionally, the samples were immersed in $100 \%$ GMA-A for 8 hours at $4{ }^{\circ} \mathrm{C}$. The samples were transferred to a Teflon®mold and the twocomponent GMA was added and allowed to polymerize for 48 hours. Sections of 10 $\mu \mathrm{m}$ were obtained by cutting with a microtome (Microm HM355S, Thermo Scientific).

Prior to staining, the sections were rehydrated in DI-water for 10 minutes. For Masson trichrome staining, sections were stained with Weigert's hematoxylin solution (Sigma-Aldrich kit) for 15 minutes before they were washed in running tap water for 5 minutes. The samples were then immersed in $1 \%(\mathrm{v} / \mathrm{v})$ acetic acid for 30 seconds before staining with azophloxin for 15 minutes, followed by another immersion in $1 \%$ $(\mathrm{v} / \mathrm{v})$ acetic acid for 30 seconds. Then, the slides were immersed in Tungstophosphoric acid Orange $\mathrm{G}$ for 1 minute, followed by the $1 \%(\mathrm{v} / \mathrm{v})$ acetic acid step. The last staining was added by immersing in Light Green SF for 8 minutes followed by an $1 \%(\mathrm{v} / \mathrm{v})$ acetic acid immersion for 30 seconds. The samples were dehydrated with ethanol, coverslips were mounted and imaging was carried out using a Nikon Eclipse E600 with a Nikon DS-Fi1c camera (Figure 2D) and a digital slide scanner (Supplementary Figure S.5.11) (Hamamatsu Nanozoomer 2.0RS).

\section{SEM}

Samples were dehydrated by the use of an ethanol gradient series of $60 \%, 70 \%, 80 \%$ , $90 \%, 96 \%$ and $100 \% \mathrm{v} / \mathrm{v}$ ethanol in DI-water. The scaffolds were further processed by critical point drying from liquid carbon dioxide using a Balzers CPD 030 critical point dryer. The dried samples were gold-sputter-coated (Cressington) and imaged with scanning electron microscopy (SEM) using a Philips XL 30 ESEM-FEG.

\section{Injectability Tests}

To test the injectability of the micro-objects, a suspension with a concentration of approximately 5,000 objects per $\mathrm{mL}$ was prepared. As a second group, objects and cells were mixed in basic cell culture medium with a density of approximately 20,000 
hMSCs and 5,000 objects per mL. To give an impression of injectability, we extruded the a suspension of cells and objects through a 18G needle into a well plate and into a punched hole in a agarose gel $(1 \% \mathrm{w} / \mathrm{v})$ (Videos are available upon request). A similar test was performed for a micro-aggregate suspension. The suspensions were easily extruded into the well plate and the gel without the need to apply high forces. With respect to translation into clinical applications in a later stage, we hypothesize that the micro-aggregates could be injected with, for example, a (degradable) hydrogel as injection medium. Firstly, the hydrogel could help to retain the micro-aggregates in the site of administration. Secondly, such a gel could ease the handling of the suspension due to its higher viscosity. Micro-aggregates were incorporation into an alginate solution $(2 \% \mathrm{w} / \mathrm{v})$ after which it was extruded through a syringe in a mold and subsequently cross-linked by a $\mathrm{CaCl}_{2}$ solution. After injection, the aggregates in suspension as well as the aggregates in the alginate gel were kept in culture for 6 hours to assess cell survival (Supplementary Figure $12 \mathrm{E}$ and F).

\section{Mechanical analysis by uniaxial compression}

Compression tests were conducted on a rheometer (Physica MCR501, Anoton Paar) equipped with a PP25 parallel-plate measuring system. The compression tests were ran with a velocity $v[\mathrm{~m} / \mathrm{s}]$ of $1 \%$ of initial height $l$. The stress $\left[\mathrm{N} / \mathrm{m}^{2}\right]$ is calculated as a function of normal force $[\mathrm{N}]$ per contact surface area $A\left[\mathrm{~m}^{2}\right] . A$ is determined by the displacement $\Delta l[\mathrm{~m}]$ and volume of the sample. To simplify the correction of $A$ for the initially cylindrical gels, a perfect cylinder is assumed during the test neglecting frictional forces. To correct $A$ for a heterogeneous micro-aggregate under compression involves complex modelling $[36,37]$. Therefore, to simplify the estimation of $A$ for the micro-aggregates, initially a perfect sphere was assumed to calculate the aggregates volume. Under compression the changes in $A$ was calculated as an function of the cross-sectional area of the initial sphere at the height of displacement and the surface area of a perfect cylinder with similar volume. The strain $\varepsilon$ is given by $\Delta l / l$. The Young's modulus $[\mathrm{Pa}]$ is calculated as an average of $\sigma / \varepsilon$ for the initial linear part of the stress/strain curve corresponding to elastic deformation. As a reference material, alginate hydrogel ( $2 \% \mathrm{w} / \mathrm{v}$, FMC Biopolymer, Norway) was cross-linked for 45 minutes in a $\mathrm{CaCl}_{2}$ solution (50mM, Sigma) containing HEPES (10mM, Gibco).

\section{Mechanical analysis by AFM}

Nano-indentation measurements were conducted by atomic force microscopy (AFM) (Veeco Dimension Icon). Samples were measured in wet-state directly after taken from the culture media. As a reference material with a relatively high elastic modulus, PDMS was analyzed, and as a material commonly used in biomedical applications, polyethylene glycol diacrylate (PEGDA) was assessed. Analysis of the data was performed using Gwyddion Freeware [38].

\section{Results}

Contact angle and relative protein adsorption tests were performed to determine the wettability of the materials (Table S5.1). The sulphuric acid treatment changed the 
morphology of the outer layer of the material so strongly that it had a gel-like appearance in suspension. This could be the cause of the low protein adsorption on these materials when compared to non-treated SU-8 and 5 minutes oxygen-plasmatreated SU-8. A BSA absorption test was performed by incubating all samples and a non-tissue-culture-treated polystyrene plate with $25 \mu \mathrm{g} / \mathrm{mL}$ BSA-FITC (Sigma) for 1 hour, followed by three PBS rinsing steps and fluorescent imaging. The relative BSA absorption is given as the average pixel brightness which was determined by histogram analysis of the fluorescent images. The fluorescent signal was corrected for autofluorescence of the materials, which in the case of SU-8 and especially 10 minutes oxygen-plasma-treated SU-8 was quite high in comparison to the signal of the adsorbed protein. This could explain the relative low value in BSA absorption for 10 minutes oxygen-plasma-treated SU-8.

As shown in Table S5.2 and as expected, the Young's modulus of alginate is in the $\mathrm{kPa}$ range. The cell-object aggregates show a nearly ten-fold increase in Young's modulus. The alginate gels with objects or micro-aggregates incorporated did not show an increase in Young's modulus with respect to alginate alone. This could be caused by the lower percentage of alginate, since a certain volume of objects and micro-aggregate suspension diluted the alginate to $1.45 \%$. Furthermore, the concentration of the relatively stiff objects and micro-aggregates was probably not sufficient to dominate over the mechanical properties of the softer alginate gel. Moreover, as mentioned in the methods, all samples are assumed as homogeneous materials. However, the aggregates and the alginate gels containing objects or micro-aggregates represent several domains (fluid, cells, ECM, SU-8) for which the individual mechanical properties are very likely distinct. Depending on, among others, parameters their ratio, organization and frictional properties, this heterogeneity introduces complexity into the mechanical characterization of such aggregates [39].

To obtain an impression of the distinct domains of mechanical properties within a heterogeneous aggregate, AFM analysis was performed. As can be seen in the table, the modulus found for PDMS is higher than expected whereas the modulus of SU-8 detected on the surface of an object within an aggregate was lower than the modulus of SU-8 as reported in literature (GPa range). It could be that the surface of the objects surface was not clean. A thin layer of deposited proteins or the membrane of a spread cell could have resulted in a compromised result. Furthermore, at higher applied forces the object could slightly be compressed into the surrounding material [40]. When a layer of tissue or ECM-like material on an object was observed by optical microscopy via the AFM, the results of indentation at these areas show slightly lower Young's modulus than the tissue in between the objects. This could be caused by multiple factors, such as cell orientation or ECM density.

Table S5.1 Contact angle and relative protein adsorption

\begin{tabular}{|c|c|c|}
\hline & Contact Angle & Relative BSA adsorption \\
\hline \hline Non-treated SU-8 & $84.3 \pm 0.2^{\circ}$ & $30.2 \pm 2.4$ \\
\hline 5 min O2-plasma-treated SU-8 & $57.5 \pm 6.3^{\circ}$ & $23.0 \pm 3.6$ \\
\hline 10 min O2-plasma-treated SU-8 & $35.4 \pm 6.7^{\circ}$ & $3.22 \pm 0.6$ \\
\hline H2SO4-treated SU-8 & $31.2 \pm 8.0^{\circ}$ & $11.2 \pm 9.5$ \\
\hline Non-tissue-culture-treated PS & $70 \pm 0.1^{\circ}$ & $16.9 \pm 1.1$ \\
\hline
\end{tabular}


Table S5.2 Young's modulus after compression mode rheology

\begin{tabular}{|c|c|}
\hline & Young's modulus [kPa] \\
\hline \hline Alginate gel $(2 \% \mathrm{w} / \mathrm{v})(\mathrm{n}=2)$ & $26.37 \pm 19.98$ \\
\hline Alginate gel $(1.45 \% \mathrm{w} / \mathrm{v})$ with micro-objects $(\mathrm{n}=3)$ & $17.37 \pm 13.33$ \\
\hline Alginate gel $(1.45 \% \mathrm{w} / \mathrm{v})$ with micro-aggregates $(\mathrm{n}=3)$ & $4.44 \pm 4.46$ \\
\hline SU-8 aggregates $(\mathrm{n}=4)$ & $181.65 \pm 190.7$ \\
\hline
\end{tabular}

Table S5.3Young's modulus after nanoindentation with AFM

\begin{tabular}{|c|c|}
\hline & Young's modulus [MPa] \\
\hline \hline PDMS & $38.8 \pm 0.91$ \\
\hline PEGDA (5\% w/v) & $0.14 \pm 0.04$ \\
\hline SU-8 aggregate (on object) & $149 \pm 4.32$ \\
\hline SU-8 aggregate (on tissue) & $0.18 \pm 0.07$ \\
\hline SU-8 aggregate (tissue on object) & $0.11 \pm 0.04$ \\
\hline
\end{tabular}

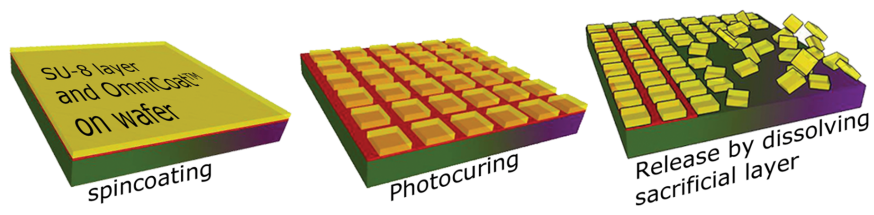

Figure S5.1:Schematic overview of the fabrication process of SU-8 micro-objects. The OmniCoat ${ }^{\mathrm{TM}}$ sacrificial layer (red) was spin-coated on a 4 inch silicon wafer (green) followed by a $44 \pm 2 \mu \mathrm{m}$ layer of SU-8 (yellow). Exposure through a mask to a $\mathrm{Hg}$ light source photo-cured the SU-8 following the mask pattern. The unexposed photoresist was dissolved. The objects were released from the wafer by dissolving the sacrificial layer.

\section{Number of objects in an aggregate}

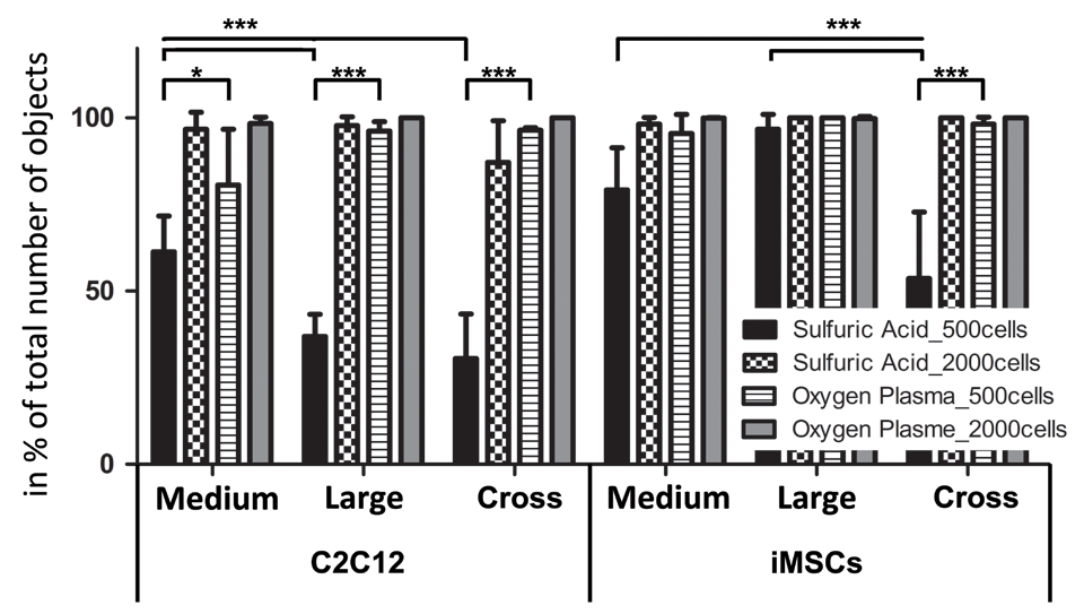

Figure S.5.2: The number of objects incorporated in the aggregates is quantified after 4 days of culture to investigate if there is a difference in aggregation behavior depending on cell type and number, and object size, shape and wettability. $(\mathrm{n}=4)\left({ }^{*} \mathrm{p}<0.05,{ }^{* *} \mathrm{p}<0.01\right.$, $* * * \mathrm{p}<0.001)$ 


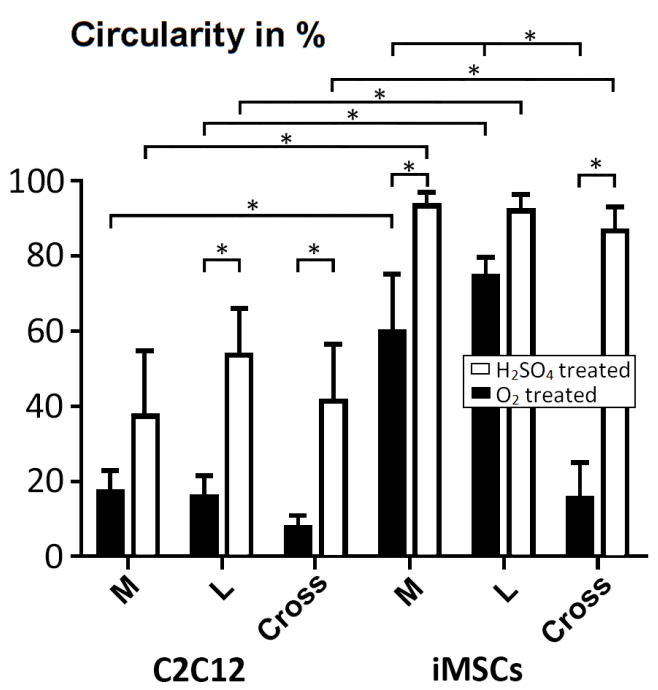

Figure S.5.3:The circularity of the aggregates was determined after 4 days of culture by measuring both the perimeter and area of a 2D projection of the aggregate. Aggregates of oxygen-plasma-treated objects show higher circularity for all objects sizes and shapes and for both cell types compared to aggregates of sulfuric acid treated objects. In five out of six conditions, aggregates of iMSCs and objects show a significantly higher circularity than aggregates of $\mathrm{C} 2 \mathrm{C} 12$ cells and objects. $(\mathrm{n}=4)\left({ }^{*} \mathrm{p}<0.05,{ }^{* *} \mathrm{p}<0.01,{ }^{* * *} \mathrm{p}<0.001\right)$

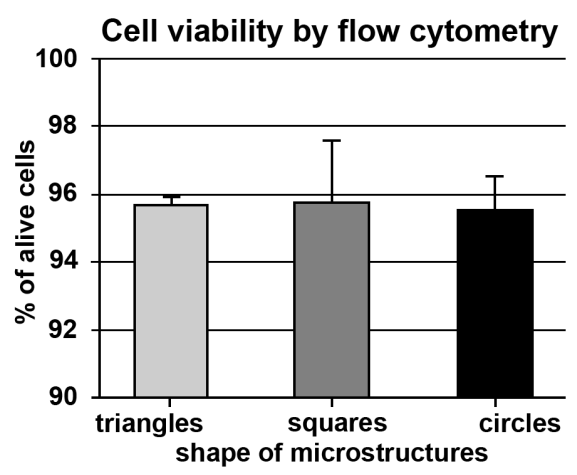

Figure S.5.5: Cell viability of hMSCs after 4 days of culture on micro-objects was determined by flow cytometry. It is shown that the shape of the objects does not influence the cell viability. The cells were trypsinized prior to flow cytometry. The result is a semi-relative number since the threshold intensity for labelled dead cells is set manually by running an analysis on a mixed population of alive and dead cells. 


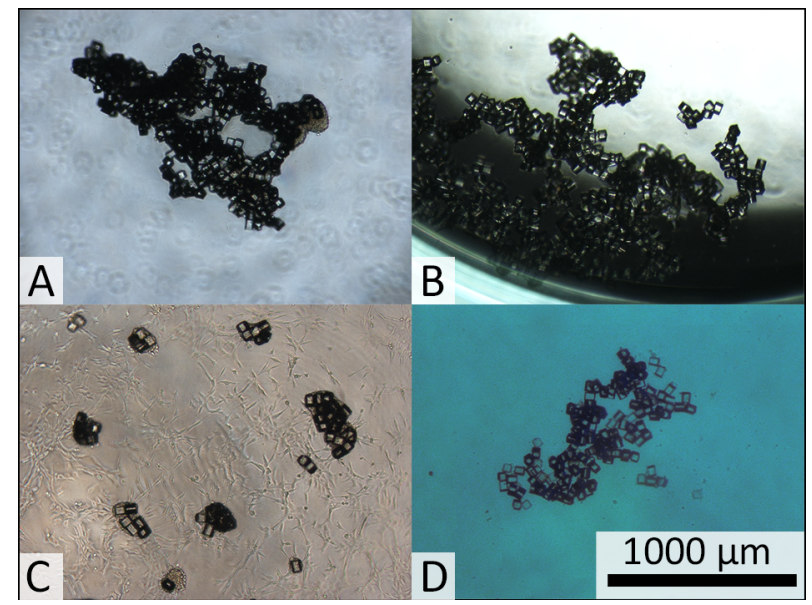

Figure S.5.4:The aggregation behavior of $\mathrm{C} 2 \mathrm{C} 12$ cells and medium-sized cubes on various culture substrates is shown. (A) A 1\% agarose layer with a hemispherical bottom resulted in aggregate formation in the center of the well. The density of the aggregates depends on the cell-object ratio. (B) When a completely flat agarose layer is used, the aggregates are formed at the side of the wells and show a more open structure. This is expected because on a flat-bottom well aggregation is not promoted due to gravitational forces. (C) In a round-bottom suspension culture plate, small aggregates are attached to the plate by the cells which spread over the surface of the untreated polystyrene. (D) When the objects and cells are cultured in a hanging drop, aggregation is found to happen at the lowest point of the drop, due to gravity-driven focussing. The cells and objects cannot interact with a substrate and therefore form hemispherically shaped aggregates partially following the shape of the interface of the medium drop with air.

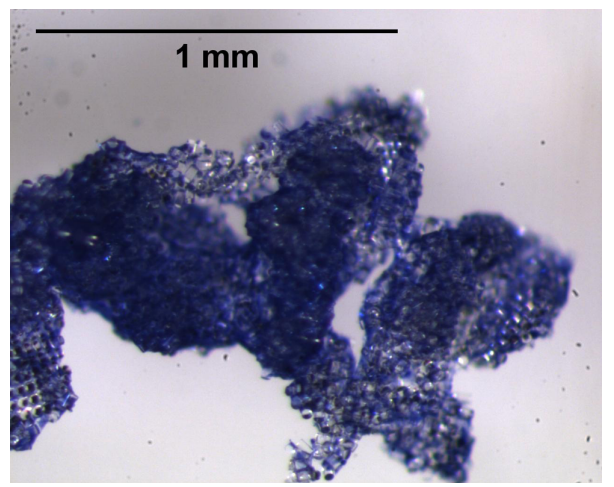

Figure S.5.6:Methylene blue staining showed that hMSCs were distributed homogeneously throughout the whole aggregate. 


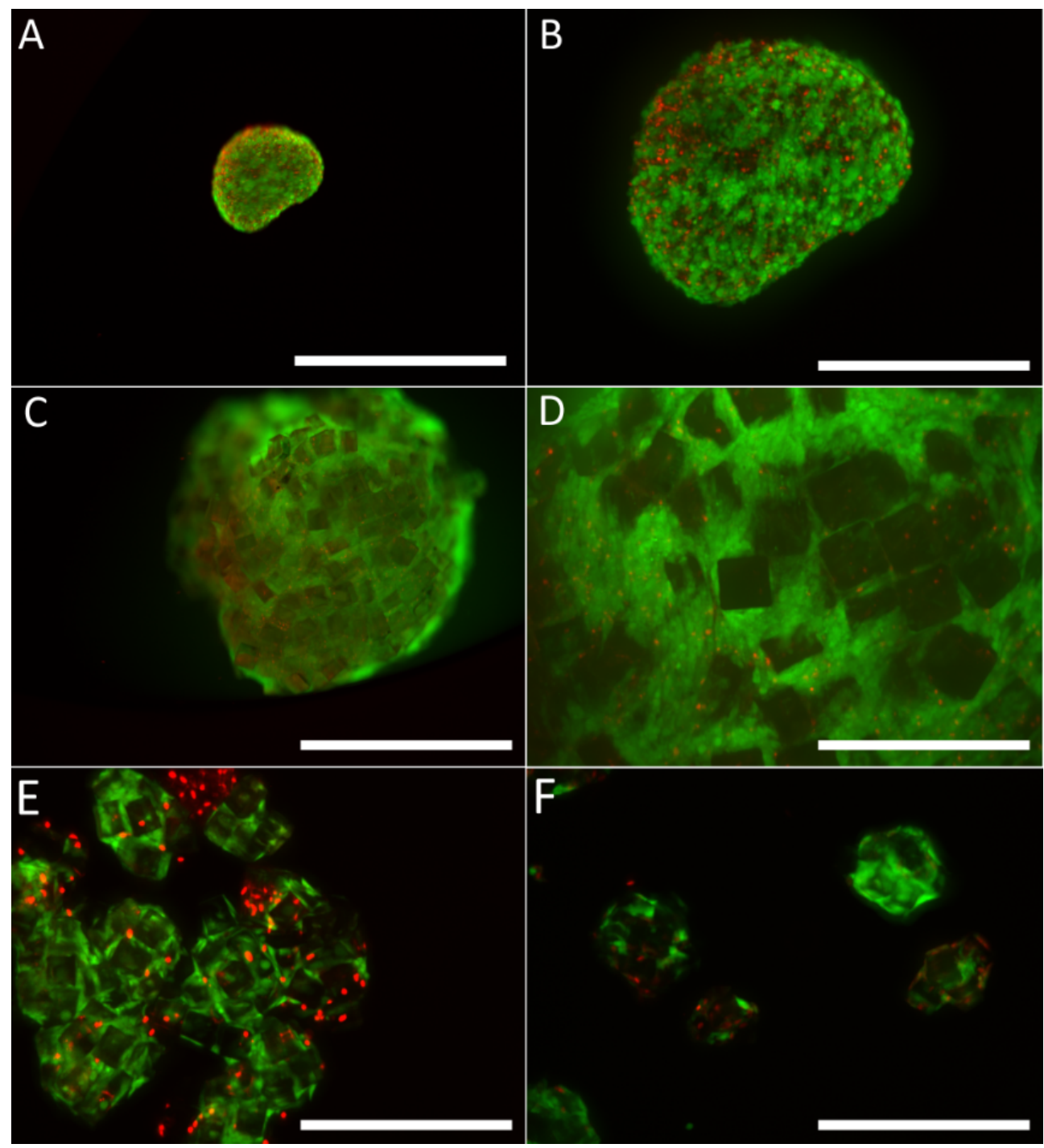

Figure S.5.7:Live (green)/dead(red) staining by propidium iodide and ethidium-homodimer after 4 days of culture shows higher viability for cells on SU-8 micro-objects (C, D) than when cultured without a substrate material (A, B). Cells death observed in 11 days old micro-aggregates 6 hours after extrusion through a surgical needle was higher than for unextruded aggregates (data not shown) both when injected as a suspension in cell culture medium(E) and in an alginate solution(F). Scale bars represent (A, C) $200 \mu \mathrm{m}$ and (B, DF) $100 \mu \mathrm{m}$. 

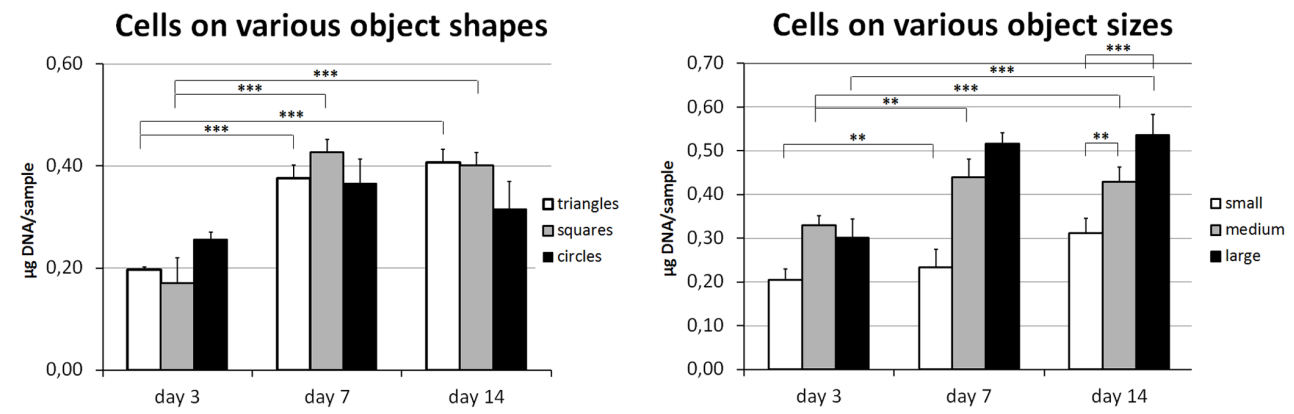

Figure S.5.8:After 3, 7 and 14 days of culture, a DNA assay was performed on hMSCs cultured with objects of different shapes and sizes $(n=3)$. It can be seen that there is a significant increase in the number of cells from day 3 to day 7 , not from day 7 to day 14 . When comparing the number of cells cultured on micro-objects with cube shapes of different sizes, hMSCs seem to adhere and proliferate more on larger objects. $\left({ }^{*} \mathrm{p}<0.05,{ }^{* *} \mathrm{p}<0.01\right.$, $* * * \mathrm{p}<0.001)$

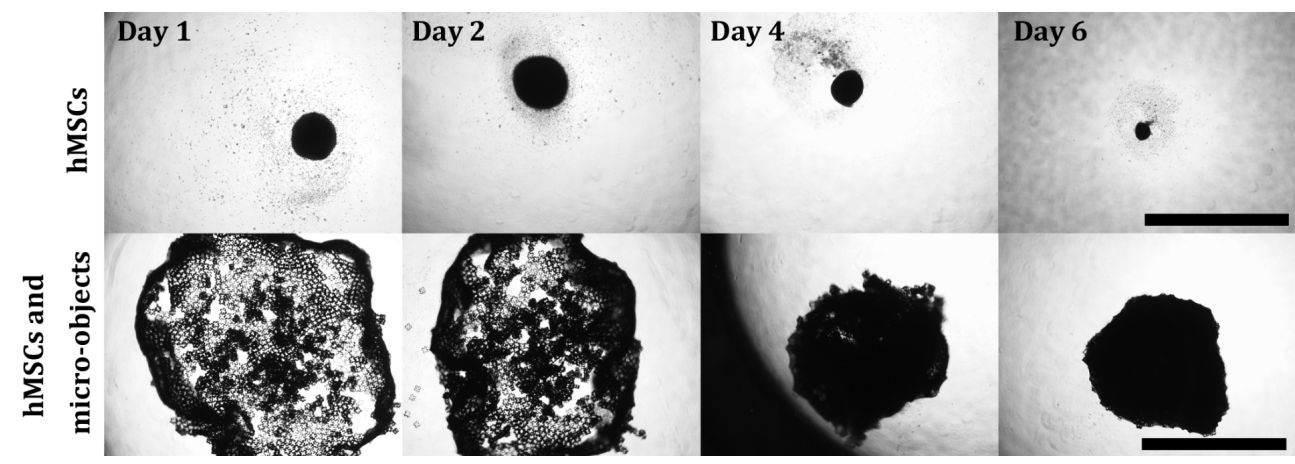

Figure S.5.9: Cells only (upper row) and cells with objects cultured on a hemispheric layer of $1 \%$ agarose are observed over time. The volume of the aggregate is decreasing when cells are cultured in the absence of a substrate material. When hMSCs are cultured with objects, cells will assemble the objects into a dense aggregate from which the volume is much higher than that of a cellonly aggregate. This shows that the objects do not only serve as a substrate for the cells to adhere to, but also as a filler to obtain larger tissue constructs than achieved without micro-objects. 


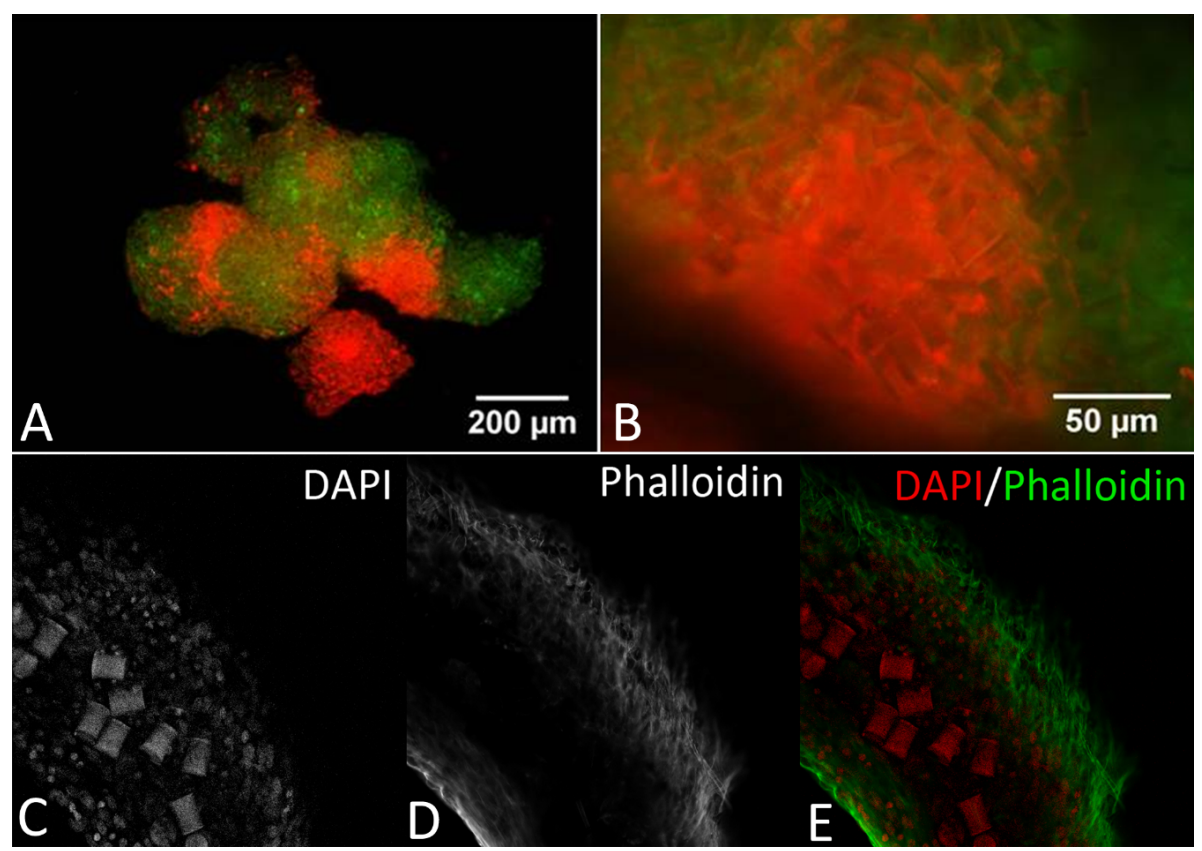

Figure S.5.10:(A, B) A Di-I and Di-O staining show active remodelling of aggregates and migration of cells from one aggregate to another within 4 days after fusion of several prestained aggregates. (CE) From DAPI (red) and Phalloidin (green) applied on the stacked toroids (as shown in Figure $5 \mathrm{E}$ and $\mathrm{F}$ ) can be seen that the cells form a homogeneous dense layer around the micro-objects. The lower signal of phalloidin in the inner part of the ring is possibly caused by the limited penetration depth of the stain, since there is no evidence of necrosis in other analysis (histological sections, flow cytometry and live/dead stain).
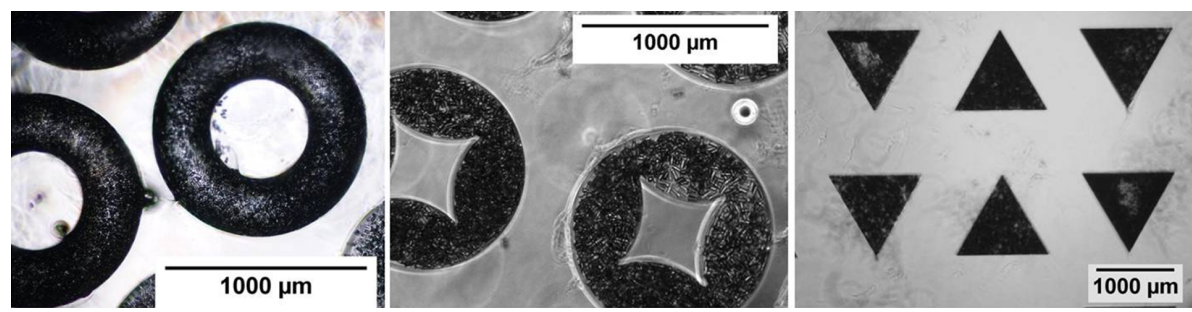

Figure S.5.12:Various geometries of pre-shaped tissue constructs can be obtained by the use of shaped wells from agarose. Pre-shaped aggregates can be created in distinct geometries such as rings or triangles. These aggregates can be fused into complex tissue constructs by, for example, combining aggregates assembled from different object and cell types. 


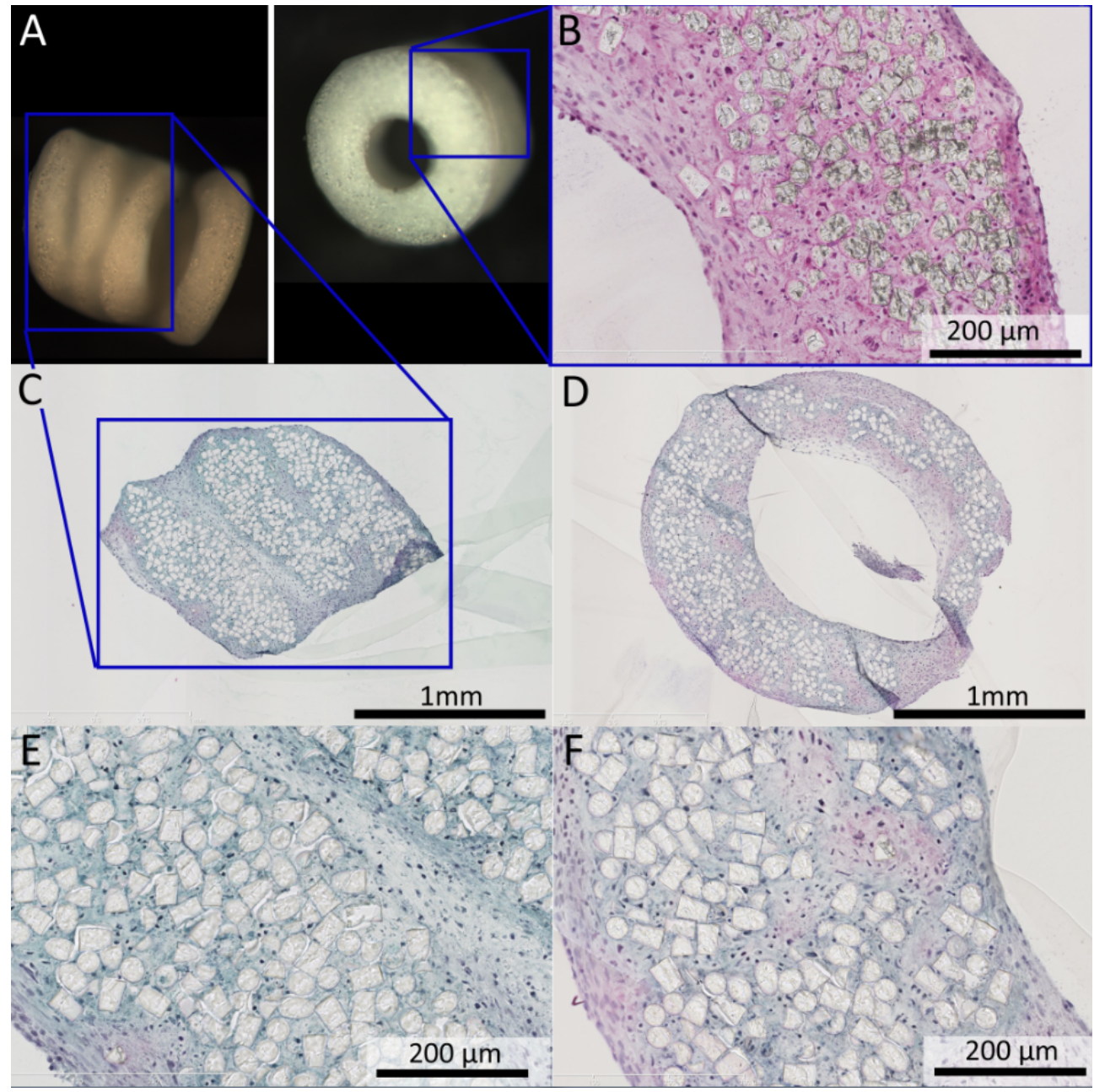

Figure S.5.11:Histological analysis of large tissue constructs show that cells remain inside the constructs and have remained viable until fixation (nuclei observed) even though the construct is mm-sized. (B) Hematoxylin and eosin staining shows the nuclei and cytoplasm, respectively. (C-F) A Masson Trichrome staining colored nuclei dark and collagen-like material green. It can be observed that there is more collagen produced in the vicinity of the objects than in between the stacked rings or at the outside of the construct. Furthermore, cells show higher densities at the exteriors; this gives the impression that the cells were proliferating. 


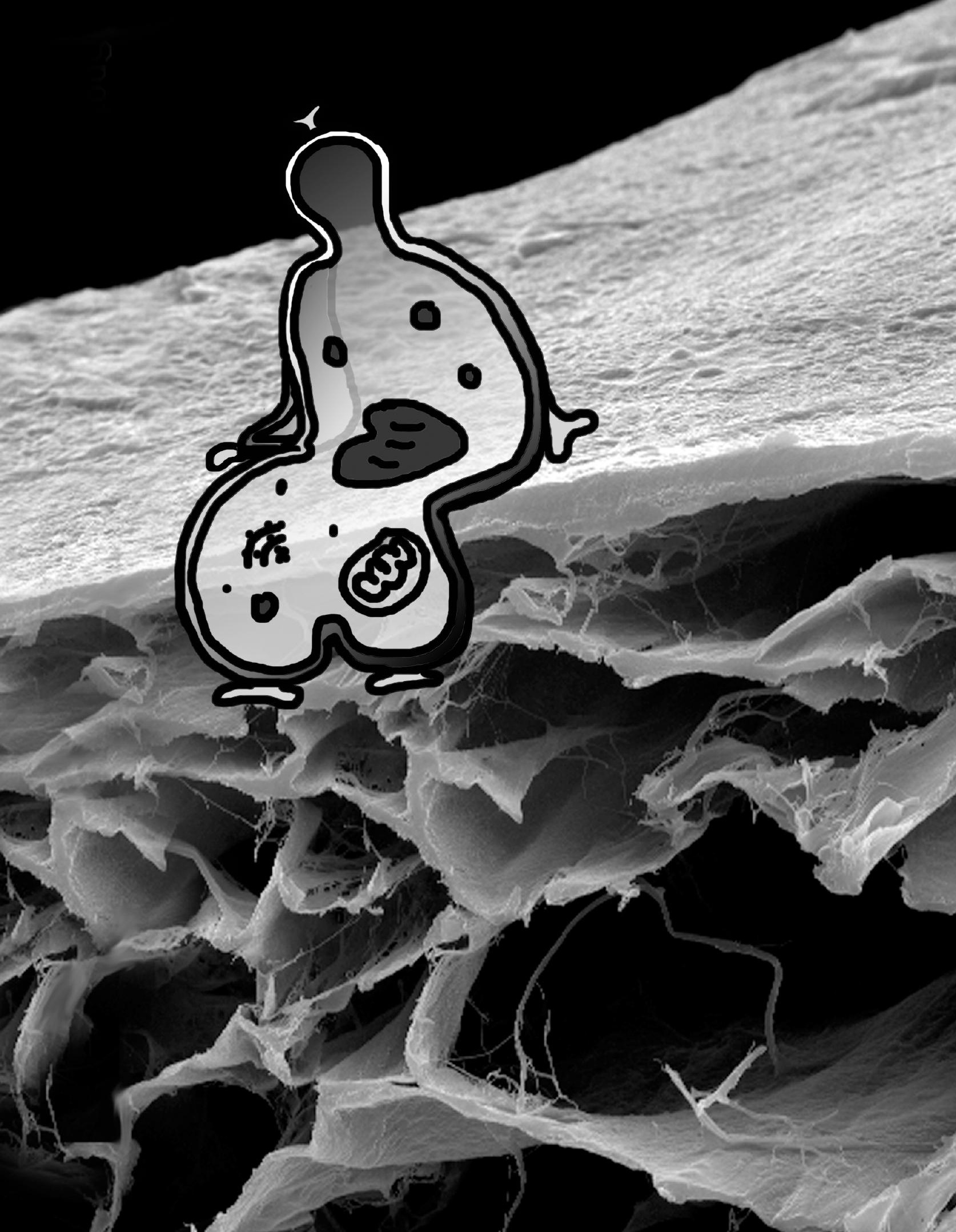




\section{Chapter 6}

\section{Differentiation capacity of human mesenchymal stromal cells cultured in three distinct types of 3D polymeric scaffolds}

\footnotetext{
A. M. Leferink ${ }^{1}$, D. Santos ${ }^{1}$, M. Karperien ${ }^{2}$, R. K. Truckenmüller ${ }^{1,3}$, C. A. van Blitterswijk ${ }^{1,3}$, L. Moroni ${ }^{1,3}$

${ }^{1}$ Department of Tissue Regeneration and ${ }^{2}$ Department of Developmental Bioegineering of MIRA Institute for Biomedical Technology and Technical Medicine, University of Twente, The Netherlands

3 Department of Complex Tissue Regeneration, Faculty of Health, Medicine and Life Sciences, Maastricht University, Maastricht, The Netherlands
} 


\begin{abstract}
Many studies have shown the influence of soluble factors and material properties on the differentiation capacity of mesenchymal stromal cells (MSCs) cultured as monolayers. These types of $2 \mathrm{D}$ studies can be used as simplified models to understand cell processes related to stem cell sensing and mechano-transduction in a three-dimensional (3D) context. For several other mechanisms such as cell-cell signaling, cell proliferation and cell morphology, it is well-known that cells behave differently on a planar surface compared to cells in 3D environments. In this study, the differentiation potential of human MSCs (hMSCs) into the chondrogenic and osteogenic lineage on three distinct $3 \mathrm{D}$ scaffolds was assessed. There was no indication that the three scaffolds induced differentiation in the absence of differentiation inducing soluble factors. Furthermore, hMSCs cultured in 3D on the three scaffold types showed to differentiate in the presence of soluble factors to the same extent as hMSCs cultured as monolayer. Yet, the differentiated phenotype was not maintained after soluble factor removal, suggesting that MSCs plasticity is retained in $3 \mathrm{D}$ cell culture systems. This finding can have implications for future tissue engineering approaches in which validation of hMSCs differentiation on 3D scaffolds will not be sufficient to ensure the maintenance of the cells functionality in the absence of proper differentiation signals.
\end{abstract}

Keywords: Human mesenchymal stromal cells, plasticity, differentiation, electrospinning, fused deposition modeling, bottom-up tissue engineering 


\subsection{Introduction}

Multipotent cell types are promising candidates for classical tissue engineering and regenerative medicine approaches in which a synthetic or biological material is combined with autologous cells to construct a mechanically stable implant to replace damaged or lost tissue. The use of multipotent cell types is opted since many other differentiated cell types have a limited availability and several cell types have shown to lose their phenotype upon expansion by a process known as de-differentiation [1-4]. This can result in a decreased functionality of the cells, which lowers their potential to secrete specific tissue components within the construct. One of the cell types that can reduce this problem are human adult stem cells from bone marrow stroma, referred to as human mesenchymal stem cells or human marrow stromal cells (hMSCs). MSCs were initially defined as a heterogeneous population of fibroblast-like cells, from which a subset of the population has a great potential to proliferate and differentiate [5-8]. More recent definitions consist of minimal criteria to identify multi-potent hMSCs which include specific surface antigen expression and multipotent differentiation potential into osteoblasts, adipocytes and chondrocytes [9-11]. Recent studies showed that by culturing hMSCs on biomaterials with controlled properties, or by adding certain soluble factors, depending on the donor and isolation method, differentiation towards chondrogenic [12-14], osteogenic [15-17], neurogenic [18], endothelial [19] and myogenic [20] lineage can be achieved.

A large body of studies have shown the influence of soluble factors and material properties on the differentiation capacity of MSCs in two-dimensional (2D) culture systems [21]. For example, Engler et al. reported on the influence of gel stiffness on stem cell fate $[22,23]$. In other studies, nano- and micro-topographies were introduced to investigate the influence of physical properties like roughness of the material on cell differentiation [24-27]. These types of 2D studies can be used as simplified models to understand cell processes related to stem cell sensing and mechano-transduction in three-dimensional (3D) systems. However, cells in a tissue, organ or organism are exposed to complex biological environments. In contrast to classic culture systems, these environments are not flat, but 3D. Consequently, 2D tissue culture models used to translate a new therapy to the clinics are far from accurate. For several other mechanisms like cell-cell signaling, cell proliferation and cell morphology, it is wellknown that cells behave differently on a 2D flat surface compared to cells on 3D systems [28]. Although MSCs lineage, plasticity and therapeutic potential have been widely studied in 2D, little is known about these combined properties in 3D [29]. In particular, plasticity is the ability of mature cells to switch or differentiate among phenotypes that are different from the tissue of origin or different from their phenotype after considerable differentiation $[30,31]$. Rottmar et al. recently reported on the plasticity of hMSCs in 3D by micro-mass culture in micro-wells. They showed that hMSCs retain their plasticity up to 18 days of $3 \mathrm{D}$ in vitro culture in osteogenic culture conditions [32]. To our knowledge, hMSCs' phenotypic plasticity after osteogenic or chondrogenic differentiation was not yet assessed in 3D scaffolds for tissue engineering approaches.

In this study, the differentiation potential of hMSCs into the chondrogenic and osteogenic lineage on three distinct 3D scaffolds, used as 3D cell culture systems, 


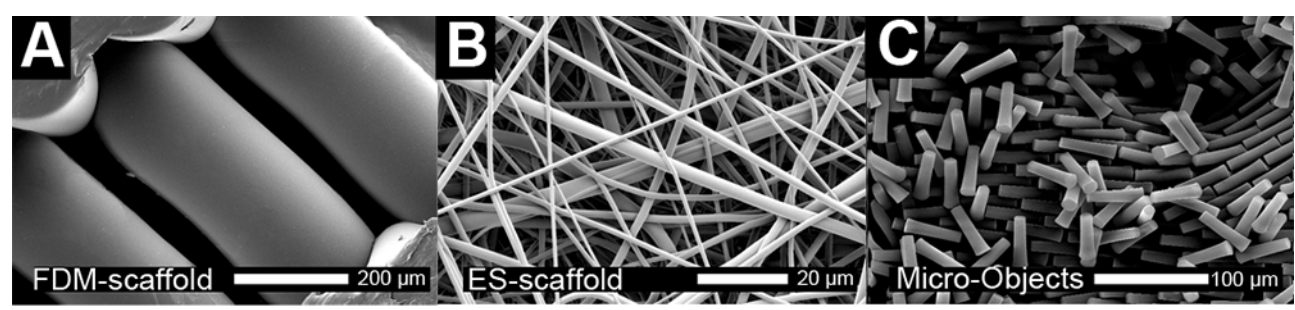

Colony Picked MSCs ${ }^{1}$
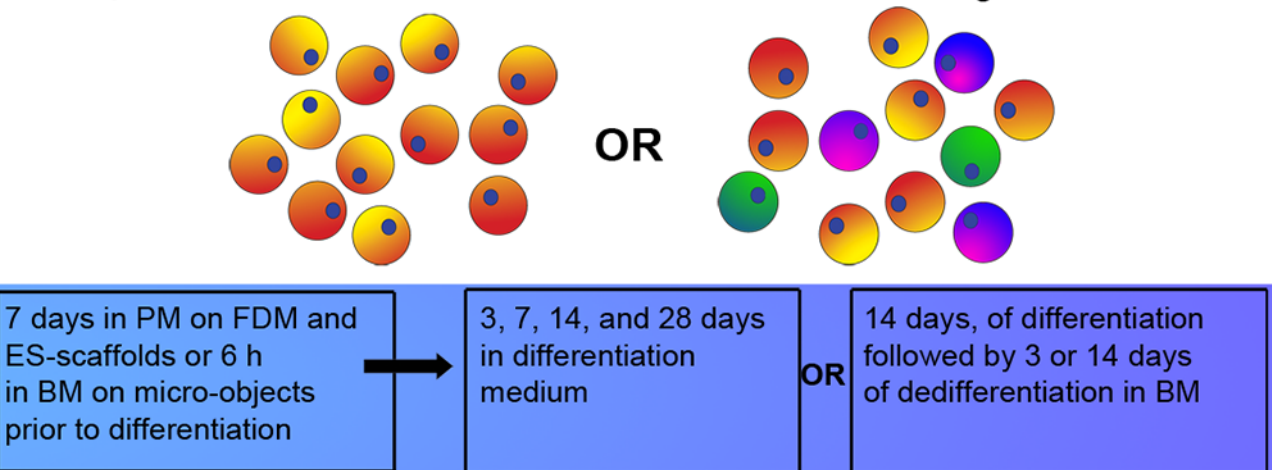

Heterogeneous MSCs ${ }^{2}$

Figure 6.1: Three distinct types of scaffolds were used to assess hMSCs differentiation capacity in vitro in 3D. (A) Cylindrical FDM-scaffolds were fabricated of 300/55/45 with a diameter of $4 \mathrm{~mm}$ and a height of $3 \mathrm{~mm}$. (B) ESP scaffolds were fabricated of the same polymer as FDM-scaffolds and punched out from a large electrospun sheet to fit in a 12well plate. (C) Micro-objects were fabricated of SU-8 with dimensions ranging from 20 to $50 \mu \mathrm{m}$. Respectively 125,000, 75,000 and 50,000 hMSCs were seeded on the three scaffold types. Both a heterogeneous population and a more homogeneous colony-picked population of hMSCs were used.

was assessed and compared to the differentiation capacity in 2D monolayer cultures. As commonly used to steer hMSCs differentiation, $10 \mathrm{nM}$ dexamethasone (dex) was supplemented to the medium for osteogenic differentiation, while $100 \mathrm{nM}$ of dex and $10 \mathrm{ng} / \mathrm{mL}$ of TGF- $\beta 3$ were introduced for chondrogenic differentiation. After 14 days of differentiation, the soluble factors were removed (de-differentiation phase) and the cellular phenotype was assessed after 3 or 14 days of potential de-differentiation. We hypothesize that after removal of differentiation inducing soluble factors, the stability of hMSCs phenotype may be altered in 3D similarly to what was reported for hMSCs phenotype in 2D culture [29, 33]. Ultimately, this may have an influence in developing stem cell based regenerative medicine strategies in which constructs loaded with hMSCs are implanted in vivo subsequent to culture in vitro. In these approaches, the traditional assessment of hMSCs differentiation potential in 3D constructs will not be sufficient to predict the functionality of the hMSCs upon implantation without assessing the stability of the hMSCs differentiated phenotype. 


\subsection{Materials and Methods}

\subsubsection{Cell culture and culture media}

Basal medium (BM) consisted of $\alpha$-minimal essential medium (Life Technologies) complemented with $10 \%$ heat-inactivated fetal bovine serum (FBS; Lonza), $0.2 \mathrm{mM}$ ascorbic acid (Asap; Life Technologies), 2 mM L-glutamine (Life Technologies), 100 $\mathrm{U} / \mathrm{mL}$ penicillin (Life Technologies), and $100 \mu \mathrm{g} / \mathrm{mL}$ streptomycin (Life Technologies). Proliferation medium (PM) consisted of BM supplemented with $1 \mathrm{ng} / \mathrm{mL}$ basic fibroblast growth factor (FGF; Instruchemie). Osteogenic medium (OM) consisted of BM supplemented with $10 \mathrm{nM}$ dex. Chondrogenic medium (CM) consists of Dulbecco's modified Eagle medium (D-MEM, Life Technologies) complemented with 0.2 $\mathrm{mM}$ ascorbic acid, $100 \mathrm{U} / \mathrm{mL}$ penicillin (Life Technologies), $100 \mu \mathrm{g} / \mathrm{mL}$ streptomycin (Life Technologies), $50 \mu \mathrm{g} / \mathrm{mL}$ ITS-premix, $100 \mu \mathrm{g} / \mathrm{mL}$ sodium pyruvate, $10 \mathrm{ng} / \mathrm{mL}$ TGF $\beta-3$ and $100 \mathrm{nM}$ dex. For the studies presented here two different types of hMSC populations were utilized. For all experiments, colony-picked hMSCs (referred to as donor 1) were used unless stated differently.

Colony-picked hMSCs (male, age 22) were retrieved from the Institute of Regenerative Medicine (Temple, Texas) [8, 34]. Briefly, a bone marrow aspirate was drawn and mononuclear cells were separated using density centrifugation. The cells were plated to obtain adherent hMSCs, which were harvested when cells reach 60$80 \%$ confluence. These were considered passage zero (P0) cells. These P0 cells were expanded, harvested and frozen at passage 1 (P1) for distribution.

Donor 2, 3, and 4 hMSCs (female, age 55; male, age 75; and female, age 76; respectively) were obtained by bone marrow aspiration from patients who had given written informed consent. These hMSCs were isolated and proliferated as previously described [35]. In short, aspirates from the donors were resuspended using a 20-gauge needle, plated at a density of $5 \times 10^{5}$ cells $/ \mathrm{cm}^{2}$ and cultured in PM. Cells were grown at $37{ }^{\circ} \mathrm{C}$ in a humidified atmosphere with $5 \% \mathrm{CO}_{2}$. Medium was refreshed twice per week and cells were used for further subculturing or cryopreservation on reaching near confluence.

\subsubsection{Fabrication of 3D scaffolds from PEOT/PBT by fused deposition modelling (FDM)}

Scaffolds were fabricated from 300PEOT55PBT45 (300/55/45) (PolyVation, The Netherlands), a block copolymer composed of poly(ethylene oxide terephthalate) (PEOT) and poly(butylene terephthalate) (PBT) with a weight ratio of 55 to 45 for the two components, respectively, and a molecular weight of the starting poly(ethylene glycol) (PEG) segments of 300 Da used in the co-polymerization process. Fused deposition modeling was used to fabricate 3D grids with a bioscaffolder (SysENG, Germany), as described before [36]. Grids had a height of $3 \mathrm{~mm}$, a fiber-to-fiber distance of $800 \mu \mathrm{m}$, a fiber diameter of approximately $200 \mu \mathrm{m}$, and a layer thickness of $150 \mu \mathrm{m}$. Cylindrical scaffolds with a diameter of $4 \mathrm{~mm}$ and a height of $3 \mathrm{~mm}$ were punched from the plotted grids. 


\subsubsection{Fabrication of 3D scaffolds from PEOT/PBT by electrospinning (ES)}

For ES scaffolds, a $28 \%$ (w/v) solution of 300/55/45 was prepared in a mixture of chloroform $\left(\mathrm{CHCl}_{3}\right)$-1, 1, 1, 3, 3, 3-hexafluoro-2-propanol (HFIP) with a ratio of 78:22\% $\mathrm{v} / \mathrm{v}$. The solution was left stirring at room temperature overnight. Subsequently, the solution was loaded into a syringe and pumped at a controlled flow rate using a syringe pump (KDS 100, KD Scientific). PTFE tubing was used to connect the syringe and a needle to which a high voltage was applied (Gamma High Voltage Research Inc., FL, USA). A stainless steel collector, covered by an aluminum foil, was used to collect the spun scaffold. Scaffolds were produced using a voltage of $12 \mathrm{kV}$ applied to a $1.2 \mathrm{~mm}$ needle and placed at a distance of $25 \mathrm{~cm}$ from the collector. The flow rate was set at $15 \mathrm{~mL} / \mathrm{h}$, temperature to $25^{\circ} \mathrm{C}$, and humidity to $30 \%$.

\subsubsection{Fabrication of SU-8 micro-objects}

A photolithographic process was used to fabricate micro objects with dimensions of $40 \times 40 \times 40 \mu^{3}$ from the epoxy-based negative-tone photoresist SU-8 (MicroChem, Germany), as described previously [37]. Briefly, an N-Methyl-2-pyrrolidone (NMP) soluble sacrificial layer of OmniCoat ${ }^{\mathrm{TM}}$ (MicroChem, USA) was spun onto a bare silicon wafer. Subsequently, SU-8 was applied to the wafer and exposed using a chromium photo-mask. To harden the photoresist, a post exposure bake was performed followed by spray development to remove the unexposed areas. An oxygen plasma treatment at the TePla 300E plasma processor (Germany) $\left(50 \% \mathrm{O}_{2} ; 600 \mathrm{~W} ; 3\right.$ min) was performed to remove T-topping and to functionalize the surface of the freestanding micro-objects. The micro-objects were released from the wafer by dissolving the sacrificial layer with NMP followed by extensive washing in DI- $\mathrm{H}_{2} \mathrm{O}$.

\subsubsection{Cell culture in 2D on Tissue Culture Polystyrene (TCPS)}

The differentiation potential of the hMSCs without the presence of a 3D scaffold system was determined by culture of hMSCs as monolayer in BM and OM and as pellet-culture in CM. The cells from all donors were seeded with a density of 5000 cells $/ \mathrm{cm}^{2}$ on TCPS 6 -well plates (NUNC) and cultured for 3, 7 or 14 days in BM as a negative control on differentiation and in $\mathrm{OM}$ to induce osteogenic differentiation. To induce chondrogenic differentiation, 200,000 hMSCs per well were added in a Ubottom 96-well plate for suspension culture (NUNC), centrifuged for 3 minutes at 800 $\mathrm{g}$ and cultured for 3,7 or 14 days.

\subsubsection{Cell culture on FDM-scaffolds}

Sterilization of the scaffolds was performed in $70 \%$ ethanol twice for 30 minutes, subsequently washed in PBS first for 5 minutes and additionally twice for another 30 minutes each time and finally incubated in BM overnight prior to cell culture. Scaffolds were dried by medium aspiration and placed in a non-treated 48-well plate (NUNC). Passage 3 hMSCs were harvested from monolayer expansion, and seeded on the scaffolds with a density of 125,000 cells in $50 \mu \mathrm{L}$ of PM. After 1.5 hours of 
incubation to let the cells adhere, the medium was filled up to $1 \mathrm{~mL}$ and the culture was continued for 7 days to allow the cells to spread and proliferate on the scaffold. After 7 days of proliferation on the scaffolds, the medium was changed to BM, CM or $\mathrm{OM}$ and the culture was prolonged as depicted in Figure 6.1. After 14 days of culture in $\mathrm{CM}$ or $\mathrm{OM}$, culture in $\mathrm{CM}$ or $\mathrm{OM}$ was continued up to 28 days or the soluble factors were removed by replacing $\mathrm{CM}$ and $\mathrm{OM}$ with $\mathrm{BM}$ (referred to as $\mathrm{CB}$ and $\mathrm{OB}$ respectively).

\subsubsection{Cell culture on ES-scaffolds}

The scaffolds were washed with sterile PBS to remove any remaining traces of ethanol and then placed into a non-treated 24-well plate (NUNC). Non-treated plates were used to minimize cell attachment to the bottom of the plates. The constructs were then incubated at $37{ }^{\circ} \mathrm{C}$ in a humid atmosphere with $5 \% \mathrm{CO}_{2}$ overnight in $\mathrm{BM}$ to pre-wet them. To prevent the scaffold discs from floating, rubber O-rings (Eriks BV, The Netherlands) were used to hold the discs in place. After removing the medium used for incubation, 75,000 cells were seeded onto each electrospun scaffold. After 7 days of culture in PM, the media was replaced with BM, CM and OM to induce differentiation and the culture was continued as depicted in Figure 6.1. After 14 days of culture in $\mathrm{CM}$ or $\mathrm{OM}$, culture in $\mathrm{CM}$ or $\mathrm{OM}$ was prolonged up to 28 days or the soluble factors were removed by replacing $\mathrm{CM}$ and $\mathrm{OM}$ with $\mathrm{BM}$ (referred to as $\mathrm{CB}$ and $\mathrm{OB}$ respectively).

\subsubsection{Cell culture on micro-objects}

Prior to cell seeding, the objects were washed twice in $70 \%(\mathrm{v} / \mathrm{v})$ ethanol to sterilize them. Subsequently, the objects were washed three times with PBS to eliminate residual ethanol and incubated overnight in BM at $37^{\circ} \mathrm{C}$. Approximately 2000 microobjects were transferred to each well of a 48 -well plate coated with a hemispherical layer of $1 \%(\mathrm{w} / \mathrm{v})$ agarose in PBS. The agarose is utilized to prevent the cells and the objects from adhering to the bottom of the well and to promote cell-material contact. After allowing the objects to settle on the agarose layer a cell suspension of 50,000 cells in $20 \mu \mathrm{L}$ of BM was added to each well. After 1.5 hours, the media was filled up to $500 \mu \mathrm{L}$ with $\mathrm{BM}, \mathrm{CM}$ or $\mathrm{OM}$ and the culture was prolonged as indicated in Figure 6.1 .

\subsubsection{Gene expression analysis of hMSCs}

For gene expression analysis, samples were taken from culture after the medium was carefully aspirated. All samples were transferred to $2 \mathrm{~mL}$ Eppendorf tubes and 500 $\mu \mathrm{L}$ of TRIzol $\mathbb{R}$ (Invitrogen) was added prior to preservation at $-80{ }^{\circ} \mathrm{C}$. In the case of micro-objects, to ensure sufficient amount of RNA, 3 aggregates were pooled per tube. RNA isolation was performed by using a Bioke RNA II nucleospin RNA isolation kit (Macherey-Nagel). The samples were disrupted mechanically by crushing with RNA isolation pestles (Kimble Kontes). Samples for basal gene expression analysis were seeded in T25 tissue culture flasks (NUNC) in BM at a cell density of 5000 cells $/ \mathrm{cm}^{2}$. After 1 day of culture, medium was aspirated and $500 \mu \mathrm{L}$ of TRIzol@ was added 
Table 6.1. Primer Sequences

\begin{tabular}{|c|c|c|}
\hline Gene & Forward Primer & Reverse Primer \\
\hline B2M & GACTTGTCTTTCAGCAAGGA & ACAAAGTCACATGGTTCACA \\
\hline ALP & ACAAGCACTCCCACTTCATC & TTCAGCTCGTACTGCATGTC \\
\hline Sox 9 & TGGGCAAGCTCTGGAGACTTC & ATCCGGGTGGTCCTTCTTGTG \\
\hline Col-1 & GTCACCCACCGACCAAGAAACC & AAGTCCAGGCTGTCCAGGGATG \\
\hline Col-2 & CGTCCAGATGACCTTCCTACG & TGAGCAGGGCCTTCTTGAG \\
\hline ACAN & AGGCAGCGTGATCCTTACC & GGCCTCTCCAGTCTCATTCTC \\
\hline ALCAM & ACGATGAGGCAGACGAGATAAGT & CAGCAAGGAGGAGACCAACAA \\
\hline BMP2 & GCTAGACCTGTATCGCAGGC & TTTTCCCACTCGTTTCTGGT \\
\hline
\end{tabular}

after which the cell/TRizol suspension was transferred to an Eppendorf tube. Subsequently, $200 \mu \mathrm{L}$ of $\mathrm{CHCl}_{3}$ was added to all samples, both from $2 \mathrm{D}$ as well as from $3 \mathrm{D}$ culture, and mixed by vigorously shaking the tubes. The TRizol/ $\mathrm{CHCl}_{3}$ mixture was centrifuged at $12,000 \mathrm{~g}$ for 15 minutes at $4{ }^{\circ} \mathrm{C}$. The aqueous phase was transferred to a new Eppendorf tube and mixed 1:1 with $70 \%$ ethanol. The mixture was transferred to filter columns from the kit and the RNA isolation was continued following the manufacturer's protocol. RNA concentrations and purity were determined by using an ND1000 spectrophotometer (Nanodrop Technologies, USA). cDNA was synthesized from 180, 240, 320 and $600 \mathrm{ng}$ of RNA for the samples from the micro-objects, FDM-scaffolds, ES-scaffolds and 2D respectively, using iScript ${ }^{\mathrm{TM}}$ (BIO-RAD) according to the manufacturer's protocol. Quantitative polymerase chain reaction (qPCR) was performed on the obtained cDNA by using the iQ SYBRßGreen Supermix (Bio$\mathrm{Rad}$ ) and the primers as listed in Table 6.1. PCR reactions were carried out on the MyiQ2 Two-Color Real-Time PCR Detection System (Bio-Rad) under the following conditions: cDNA was denatured for 10 minutes at $95^{\circ} \mathrm{C}$, followed by 40 cycles, consisting of $15 \mathrm{~s}$ at $95{ }^{\circ} \mathrm{C}, 30 \mathrm{~s}$ at $60{ }^{\circ} \mathrm{C}$, and $30 \mathrm{~s}$ at $72{ }^{\circ} \mathrm{C}$. For each reaction, a melting curve was generated to test primer dimer formation and nonspecific priming. The cycle threshold (CT) values were determined with the Bio-Rad iQ5 optical system software, in which a threshold value was set for the fluorescent signal at the lower log-linear part above the baseline. CT values were normalized to the B2M housekeeping gene and $\triangle \mathrm{CT}$ ((average of $\left.\left.\mathrm{CT}_{\text {control }}\right)-\mathrm{CT}_{\text {value }}\right)$. Results are expressed as relative mRNA expression calculated as $2^{-\triangle C T}$ and subsequently normalized to the basal gene expression levels determined after one day in $2 \mathrm{D}$ culture $(\mathrm{n}=6)$. All values representing down-regulation (fold induction $(\mathrm{FI})<1$ ) are represented as $-1 / \mathrm{FI}$ and error bars represent standard deviations which are determined accordingly.

\subsubsection{DNA assay}

After the samples were lysed for alkaline phosphatase (ALP) activity, the lysate was mixed in a 1:1 volume ratio with $1 \mathrm{mg} / \mathrm{mL}$ proteinase $\mathrm{K}$ (Sigma-Aldrich), 18.5 $\mu \mathrm{g} / \mathrm{mL}$ iodoacetamine (Sigma Aldrich) and $1 \mu \mathrm{g} / \mathrm{mL}$ pepstatin A (Sigma Aldrich) in Tris/EDTA buffer ( $\mathrm{pH} 7.6)$ and incubated for 16 hours at $56{ }^{\circ} \mathrm{C}$. Quantication of total DNA was done using the CyQuantßDNA assay (Molecular Probes) and a spectrophotometer (excitation $480 \mathrm{~nm}$, emission $520 \mathrm{~nm}$ ) (Victor 3, Perkin Elmer). 


\subsubsection{ALP activity assay}

After culture, all scaffolds were washed gently in PBS, dried by aspirating the PBS, cut in pieces and stored at $-80{ }^{\circ} \mathrm{C}$ for at least 24 hours. After thawing, the constructs were incubated in a cell lysis buffer with a $\mathrm{pH}$ of 7.8 composed of $0.1 \mathrm{M} \mathrm{KH}_{2} \mathrm{PO}_{4}$, $0.1 \mathrm{M} \mathrm{K}_{2} \mathrm{HPO}_{4}$ and $0.1 \%$ Triton X-100, (all Acros Chemicals) for 1 hour at room temperature. Subsequently, the relative ALP activity was determined by chemo-

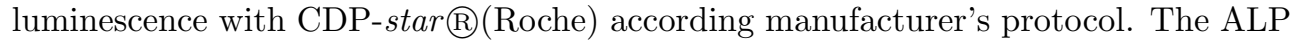
activity was normalized to DNA quantity per sample and the averages per condition were presented as relative value compared to the respective culture system in BM at day 3 .

\subsubsection{GAG assay}

The amount of GAG was determined spectrophotometrically after reaction with 16 $\mathrm{mg}$ of dimethylmethylene blue dye (DMMB, Sigma-Aldrich) in a $10 \mathrm{mM}$ hydrochloric acid solution containing $3.04 \mathrm{~g} / \mathrm{L}$ of glycine and $2.37 \mathrm{~g} / \mathrm{L}$ of $\mathrm{NaCl}(\mathrm{pH} 3)$. A micro plate reader (Multiskan GO, Thermo Fisher) was used to determine the absorbance at $525 \mathrm{~nm}$. The amount of GAG was calculated using a standard of chondroitin sulfate (Sigma-Aldrich). The GAG production was normalized to DNA quantity per sample.

\subsubsection{Scanning electron microscopy (SEM) analysis}

Cell morphology, attachment and distribution were characterized by SEM analysis with a Philips XL 30 ESEM-FEG. Samples were fixed for 30 minutes in $10 \%$ formalin. Subsequently, the samples were dehydrated in sequential ethanol series and critical point dried from liquid carbon dioxide using a Balzers CPD 030 Critical Point Dryer. The constructs were gold sputter-coated (Cressington) prior to SEM analysis. SEM images were obtained under high vacuum with an acceleration voltage of $30 \mathrm{kV}$ and a working distance of $10 \mathrm{~mm}$.

\subsubsection{Statistical analysis}

Results are presented as mean \pm standard deviation, and compared using one-way ANOVA with Dunnett's post-test. Statistical significance between the control group and the experimental groups are indicated with (\#) which represents a p-value < 0.05, (@) which represents a p-value $<0.01$, and $\left(^{*}\right)$ which represents a p-value $<$ 0.001 .

\subsection{Results}

To gain insight in the differentiation potential of hMSCs when cultured on 3D polymeric scaffolds, differentiation was induced by soluble factors. All results presented here were retrieved from colony-picked MSCs from donor 1. To be able to compare these results with the results from a more clinically relevant heterogeneous population of hMSCs (donor 2, 3 and 4), every experiment was carried out for at least one of those donors for which the results can be found in the supplementary data. 
2D TCPS
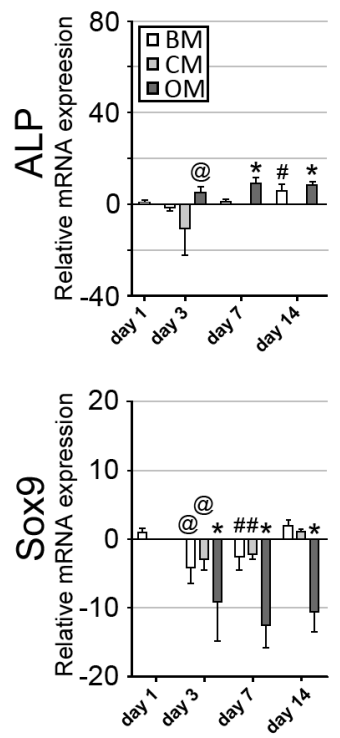

FDM-scaffolds
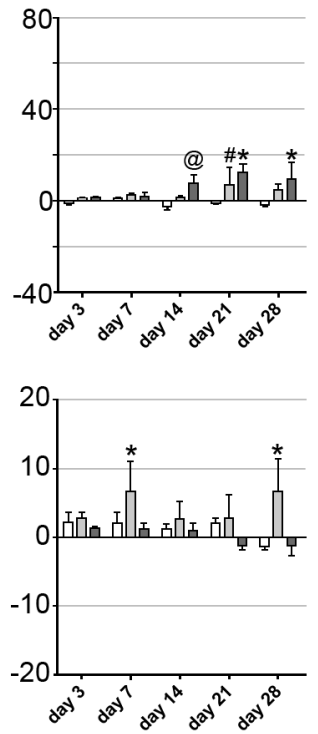

ES-scaffolds
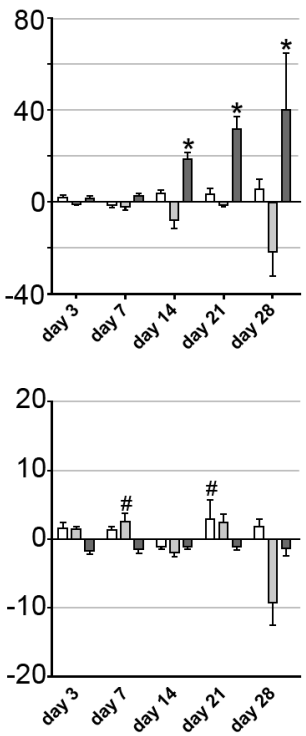

Micro-objects
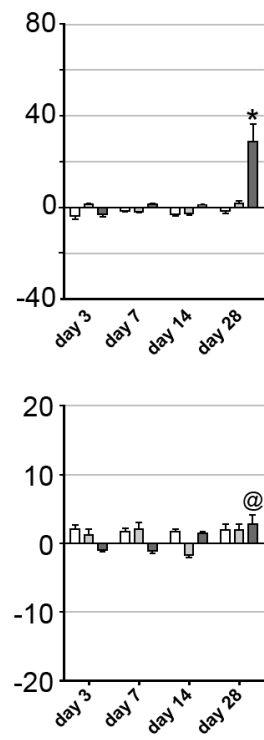

Figure 6.2: RT-QPCR analyses was carried out to determine the relative mRNA expression of ALP and Sox9 for colony-picked hMSCs cultured in 2D as monolayer (BM and OM) or micromass (CM) on TCPS and in 3D on three different scaffold systems. The mRNA expression levels were normalized and compared statistically to hMSCs cultured for 1 day as a monolayer in BM on TCPS. ALP gene expression was significantly up-regulated over time for hMSCs in 2D and in all three systems in 3D when cultured in OM. A significant down-regulation of Sox9 expression was found after monolayer or micro-mass culture in BM, $\mathrm{OM}$ and CM. Sox9 expression was significantly up-regulated after 7 and 28 days of culture in CM on FDM-scaffolds. On ES-scaffolds an initial significant increase for Sox9 expression was found after 7 days of culture in CM while the gene seemed to be down-regulated at day 14 and 28. ( $\mathrm{n}=5, \# \mathrm{p}<0.05$, @ $\mathrm{p}<0.01,{ }^{*} \mathrm{p}<0.001$ Dunnett's posttest with BM 2D day 1 as control)

\subsubsection{Differentiation potential of hMSCs in 3D scaffolds by qPCR}

The differentiation potential of hMSCs was assessed by mRNA expression analysis and normalized to the expression levels after 1 day of monolayer culture in basal medium. RT-QPCR analysis shows the relative mRNA expression of Alkaline Phosphatase (ALP) as an early marker for osteogenesis and Sox9 as an early marker for chondrogenesis (Figure 6.2). A significant up-regulation of ALP over time was found for hMSCs cultured as monolayer in OM on TCPS. In CM in 2D culture an initial down-regulation of ALP was found; after 7 and 14 days of culture the ALP expression was too low to be detected and was therefore not displayed. Comparing these results to the gene expression levels in 3D on the three scaffolding systems, it could be seen that also in 3D only OM induced consistently a significant up-regulation of ALP. CM seemed to slightly down-regulate the expression of ALP on ES-scaffolds and on 
2D TCPS
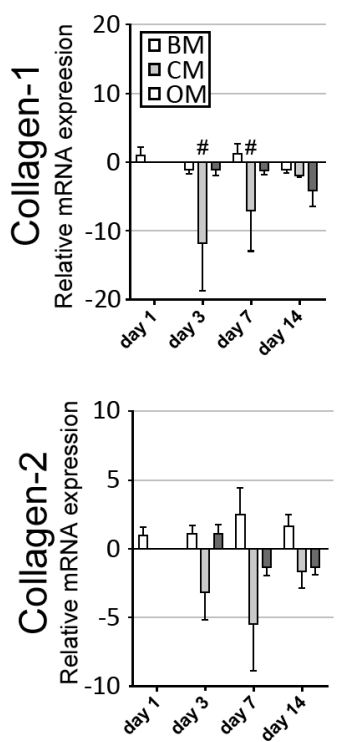

FDM-scaffolds
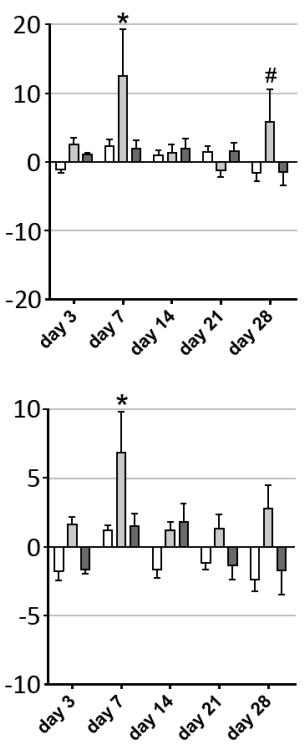

ES-scaffolds
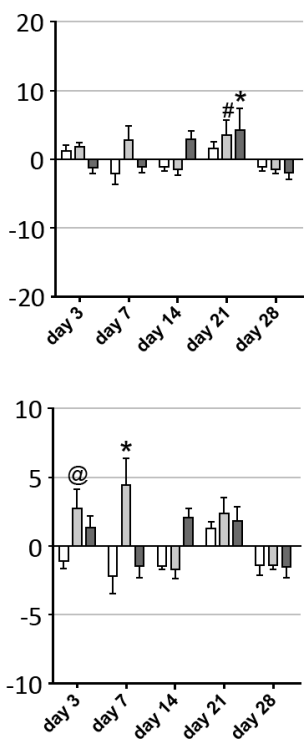

Micro-objects
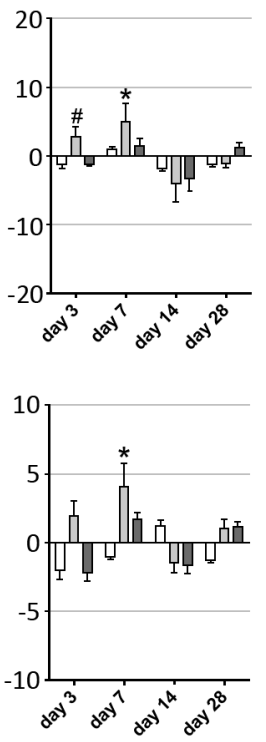

Figure 6.3: Relative mRNA expression of collagen- 1 and collagen-2 for colony-picked hMSCs cultured in 2D as monolayer (BM and OM) or micromass (CM) on TCPS and in 3D on three different scaffold systems. Collagen- 1 and collagen- 2 expression followed similar trends over time in $2 \mathrm{D}$ and in $3 \mathrm{D}$ per scaffolding system. The collagen-1 and collagen-2 expression fluctuated over-time and remained down-regulated after 28 days of culture in BM in all three scaffold types. $\left(\mathrm{n}=5, \# \mathrm{p}<0.05\right.$, @ $\mathrm{p}<0.01,{ }^{*} \mathrm{p}<0.001$, Dunnett's posttest with BM $2 \mathrm{D}$ day 1 as control)

micro-objects. In BM, the ALP expression did not show any significant changes over time in 2D nor in any of the scaffold systems. When looking at the relative expression levels, it could be seen that in 2D a 10-fold increase of ALP expression was found after 14 days of culture, which is in the same order as the fold increase in FDM and ES-scaffolds after 14 days.

Sox9 expression was significantly down-regulated in 2D culture in nearly all conditions but most profoundly in OM. In $3 \mathrm{D}$, there was a significant up-regulation observed for Sox9 expression after 7 and 28 days of culture in CM on FDM-scaffolds. On ES-scaffolds an initial significant increase for Sox9 expression was found after 7 days of culture in CM while the gene seemed to be down-regulated at day 14 and 28. On micro-objects, no significant differences were found in the Sox9 expression levels of hMSCs cultured in BM, CM or OM at nearly all time points compared to the expression levels in 2D at day 1.

Collagen-1 and collagen-2 were assessed as markers for ECM production (Figure 6.3). In $2 \mathrm{D}$ on TCPS, collagen-1 expression was significantly down-regulated in CM after 3 and 7 days. Collagen-2 expression also showed a down-regulation in CM at these time-points although these expression levels were not significantly different 
compared to the expression levels after 1 day of culture on TCPS (Figure 6.3). In 3D, the expression of both genes followed similar trends over time per scaffolding system. A down-regulation of both collagen- 1 and collagen- 2 was found in BM after 3 days of culture in the three 3D scaffold systems when compared to hMSCs in BM after 1 day of $2 \mathrm{D}$ culture. Collagen- 1 and collagen- 2 expression fluctuated over-time and remained down-regulated after 28 days of culture in BM in all three scaffold types. In CM, both genes showed an up-regulation after 3 and 7 days of culture, which was subsequently lost after 14 and 28 days of culture. Finally, hMSCs cultured in OM showed non-significant changes in the fluctuating gene expression levels, except for ES-scaffolds after 21 days of culture. This implied that the osteogenic soluble factors did not directly correlate to collagen-1 and collagen- 2 gene expression.

Another set of genes related to hMSCs differentiation was assessed for donor 1 hMSCs cultured in 2D as monolayer and in 3D on FDM-scaffolds and reported in Figure S6.1. Aggrecan (ACAN) is involved in chondrogenesis and in 2D monolayer culture the gene expression levels only showed a significant up-regulation in OM after 3 days. On FDM-scaffolds ACAN showed a significant up-regulation after 7 and 28 days of culture on FDM-scaffolds in CM. The small increase in ACAN expression in $\mathrm{BM}$ was lost after 14 days of culture and the expression levels in OM even showed a down-regulation at this time-point. BMP2 was assessed as a gene involved in osteogenesis. Culture in BM in 2D resulted in a significant 5- to 6-fold down-regulation of BMP2 expression after 3, 7 and 14 days. In contrast to the results in $2 \mathrm{D}$, a significant up-regulation of BMP2 was found in BM after 7, 14 and 21 days of culture on FDM-scaffolds, whereas in CM and OM, no significant change in BMP2 expression was found. Activated leukocyte cell adhesion molecule (ALCAM), related to the cell surface marker CD166, is often described as an indicator for hMSCs clonogenic potential [38]. It can be seen that ALCAM was significantly down-regulated a twofold in all time-points in nearly all conditions on FDM-scaffolds. Similar results were found in $\mathrm{BM}$ in $2 \mathrm{D}$ culture in which a significant down-regulation of 1.6, 2.3 and 3.5 was observed after 3, 7 and 14 days, respectively.

To compare the results of the colony-picked hMSCs in $2 \mathrm{D}$ to the results of the more heterogeneous population of hMSCs from donor 2 (Figure S6.2) and donor 4 (Figure S6.3), these cells were also cultured on 2D for 3, 7 and 14 days. In 2D culture, it could be seen that similar to the results for colony-picked hMSCs the ALP expression was down-regulated in CM for both donors. In OM, Sox9 expression was also down-regulated, while collagen-1 and collagen- 2 expression showed similar trends per donor and seemed to fluctuate between a 2-fold up- and down-regulation without a consistent change for both donors. In contrast to the results on ACAN expression for colony-picked hMSCs in 2D, hMSCs from donor 4 showed an increase in ACAN expression after 14 days of culture in CM.

To compare the expression levels of colony-picked hMSCs on 3D scaffolds to the more heterogeneous population of hMSCs from donor 2 and donor 3, cells were cultured for 3, 7, 14, 21 and 28 days on FDM- (Figure S6.4) and on ES-scaffolds (Figure S6.5) for these two donors, respectively. Donor 2 generally showed no profound gene expression level changes between the differentiation inducing culture media and BM for all genes. Also donor 3 on ES-scaffolds showed no apparent differences in gene expression levels for ALP, ACAN and ALCAM between the different culture media. 

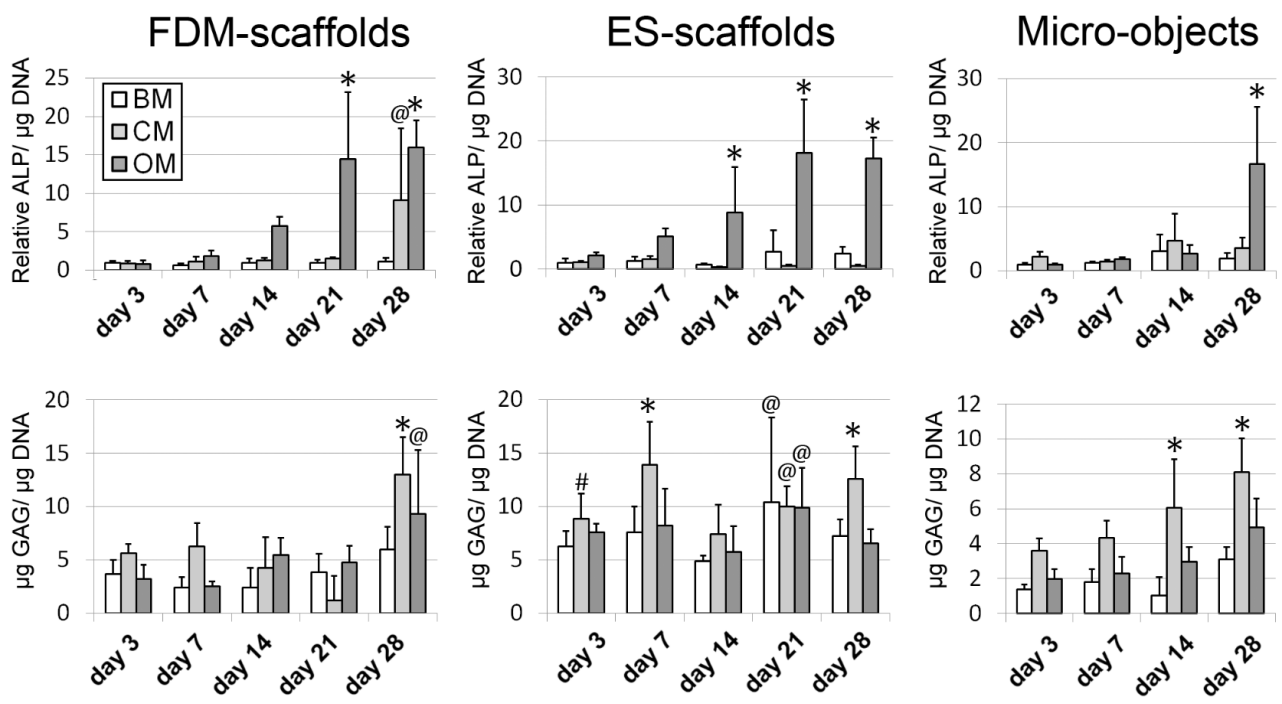

Figure 6.4: Protein expression analysis showed an increase in ALP activity over time for hMSCs in all three scaffold types when cultured in OM, whereas in BM and CM the ALP activity was maintained at a basal level. A significant increase in GAG production was observed for hMSCs cultured in CM after 28 days on FDM-scaffolds, after 3, 7, 21 and 28 days on ES-scaffolds and after 14 and 28 days on micro-objects. (FDM n $=5, \mathrm{ES} \mathrm{n}=5$, Micro-objects $\mathrm{n}=8$, \# $\mathrm{p}<0.05$, @ $\mathrm{p}<0.01,{ }^{*} \mathrm{p}<0.001$, Dunnett's posttest with BM 2D day 4 as control)

Compared to $2 \mathrm{D}$ culture at day 1 , all conditions showed a significant down-regulation of ALP at all time-points and a significant up-regulation of ALCAM. Sox9 was downregulated in CM at all time-points and in BM for all time-points after 7 days of culture. Collagen-1 expression was initially significantly up-regulated in BM and OM. After 14 days the expression stabilized at the same level as the $2 \mathrm{D}$ control after 1 day of culture. In both FDM-scaffolds and ES-scaffolds, a more profound up-regulation of chondrogenic or osteogenic marker expression after culture in $\mathrm{CM}$ and $\mathrm{OM}$, respectively, was found for colony-picked hMSCs than for the more heterogeneous populations of hMSCs from donor 2 and 3 .

\subsubsection{Differentiation potential of hMSCs in 3D scaffolds by protein expression analysis}

To investigate whether or not up-regulation of osteogenic or chondrogenic genes resulted in a functional change in the cells behavior, protein expression analysis was carried out (Figure 6.4). ALP activity was determined as an indicator of osteogenic behavior and glycosaminoglycans (GAGs) secretion was determined as an indicator for chondrogenesis. ALP activity increased significantly over time for hMSCs in all three scaffold types when cultured in OM, whereas in BM and CM it was minimally produced. A significant increase in GAG production was observed for hMSCs cultured 
in CM after 28 days on FDM-scaffolds, after 3, 7, 21 and 28 days on ES-scaffolds, and after 14 and 28 days on micro-objects. Furthermore, a significant increase in GAG production was found after 28 days in OM on FDM-scaffolds and after 21 days in OM and BM on ES-scaffolds. To compare the expression levels of colony-picked hMSCs on $3 \mathrm{D}$ scaffolds to more heterogeneous population of hMSCs, protein expression levels were determined for cells cultured for 3, 7, 14, 21 and 28 days on FDM-scaffolds (donor 2) and on ES-scaffolds (donor 3) (Figure S6.6). In contrast to the results on ALP gene expression levels found for these two donors, the ALP activity showed a positive correlation with OM. The up-regulation of ALP activity on ES-scaffolds was observed at an earlier time-point than for FDM-scaffolds, which was also observed with the colony-picked donor (Figure 6.4). GAG expression was significantly up-regulated in the presence of CM on FDM-scaffolds after 7 days of culture and on ES-scaffolds after 7, 14, 21 and 28 days of culture. In BM and OM, GAG production was also up-regulated after 14, 21 and 28 days, and after 21 and 28 days, respectively. The quantity of GAG/DNA on FDM-scaffolds showed to be higher for donor 2 hMSCs than for colony-picked hMSCs from donor 1. The quantity of GAG/DNA on ES-scaffolds was found to be in the same range.

\section{Donor 4 SEM analysis after 28 days of culture in 3D on FDM-scaffolds} $\mathrm{BM}$
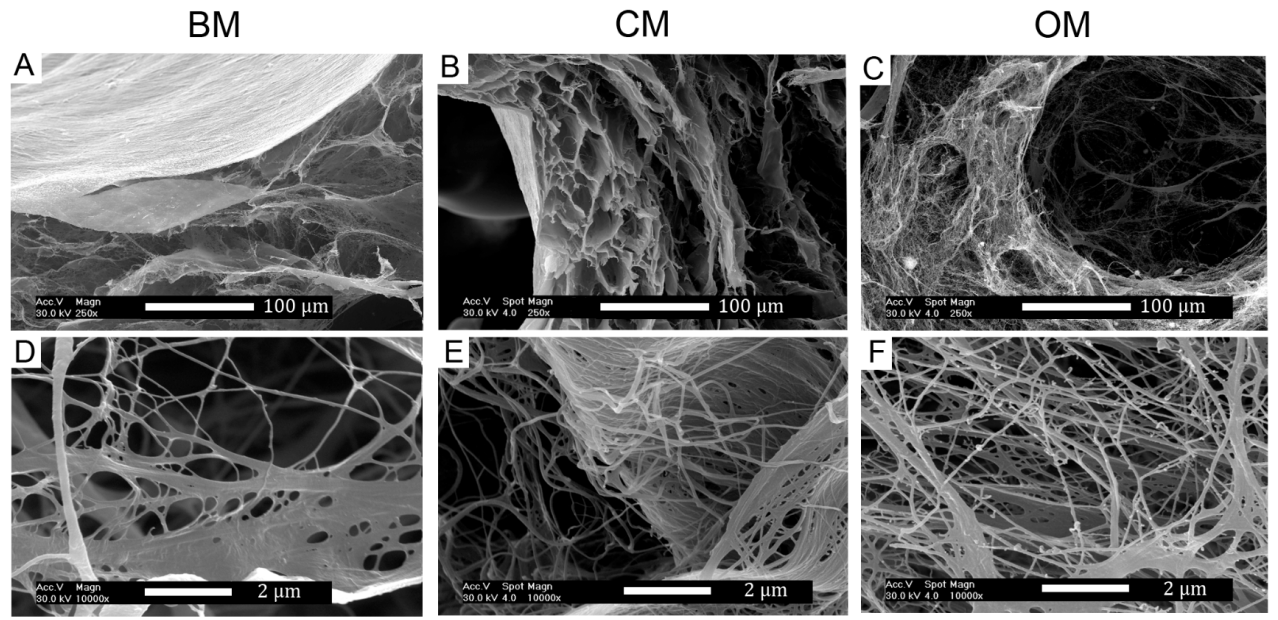

Figure 6.5: SEM analyses of donor 4 hMSCs after 28 days of culture in 3D on FDMscaffolds. In all three culture conditions BM (A, D), CM (B, E) and OM (C, F) collagen-like ECM matrix deposition was found. The scaffolds showed a dense outer layer of cells in all conditions. In CM vacuole-like structures were found which show comparable morphology as can be found in native cartilage. The cells showed to distribute throughout the whole construct in all conditions. 


\subsubsection{SEM analysis of ECM production after soluble factor induced differentiation}

The distribution and morphology of the cells and ECM throughout the 3D scaffolds were assessed by SEM (Figure 6.5 and Supplementary Figures 6.7 and 6.8). In FDMscaffolds, CM resulted often in lower cell numbers and less ECM production than $\mathrm{BM}$ and OM. Yet, the ECM that was secreted showed collagen-like ECM fibers with a tendency to align into bundles, whereas in BM and OM this orientation appeared more random. Furthermore, in CM, vacuole-like structures were observed in the ECM (Figure 6.5B). On ES-scaffolds, no profound differences were observed at the microscale and all culture media resulted in a dense cellular layer on top of the sheets with cells penetrated in between the scaffolds' fibers (Figure S6.7). Also on micro-objects no differences were found in cell morphology and distribution (Figure S6.8). In BM, the cellular sheet at the outside of the aggregate appeared smoother than in CM and OM.

\subsubsection{Loss of differentiated state of hMSCs in FDM- and ES-scaffolds upon soluble factor removal}

The stability of differentiated phenotype was assessed for colony-picked hMSCs as well as for more heterogeneous populations of hMSCs from donor 2, 3 and 4 on FDM- and ES-scaffolds. The stability of differentiated phenotype was not assessed for the micro-objects system since these objects are produced of a material that is not often applied in the clinics, despite it has shown in vivo biocompatibility. FDMand ES-scaffolds, however, are fabricated of PEOT/PBT which was already applied for in vivo tissue engineering approaches in the past. Soluble factors were removed by replacing the culture media with $\mathrm{BM}$ after 14 days of inducing differentiation into the chondrogenic (dex and TGF- $\beta 3$ ) and osteogenic (dex) lineages on FDMand ES-scaffolds, a procedure that will further be referred to as the de-differentiation phase. The culture period was prolonged with another 3 or 14 days to investigate if changes in gene expression levels and protein production were observed with respect to the specimens that were further cultured in differentiation media. Figure 6.6A shows the gene expression levels for BM, CM and OM for day 14 and day 28, as already presented in Figure 6.2 and 6.3, to enable visual comparison to results of the de-differentiation phase introduced here. As can be observed in Figure 6.6, the ALP expression significantly increased in OM after 14, 17 and 28 days in both scaffold types compared to the levels for BM after 14 days of culture. After 3 days of potential dedifferentiation, the ALP expression levels in OB were still significantly up-regulated compared to day 14 in BM, yet, a small decrease could be observed when comparing to $\mathrm{OM}$ at the same time-point. After 14 days of potential de-differentiation, there was no significant difference in ALP expression levels between samples in BM and $\mathrm{OB}$, whereas in OM the expression remained up-regulated.

Sox9 gene expression levels did not show the same trends for the two different scaffold systems. In FDM-scaffolds, a significant increase in Sox9 expression was found only after 17 days of culture in CM, whereas in ES-scaffolds a significant downregulation was found after 28 days in $\mathrm{CM}$. In $\mathrm{CB}$, no differences were observed after 
A Gene expression
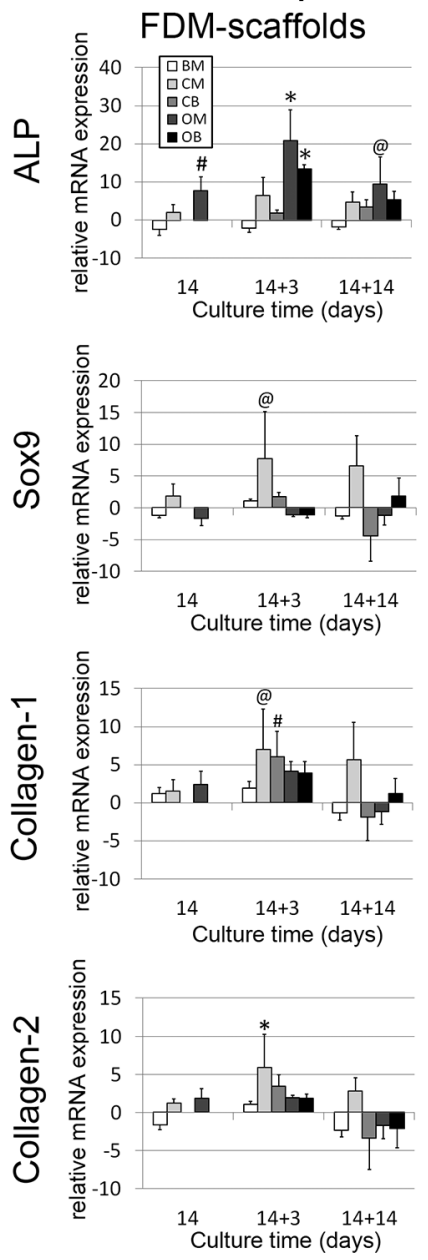
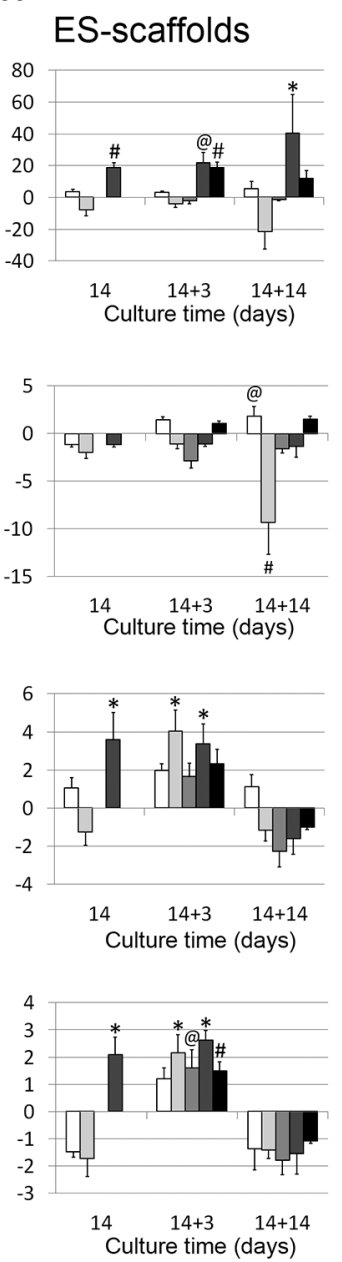

B Protein Activity

ALP activity on FDM-scaffolds

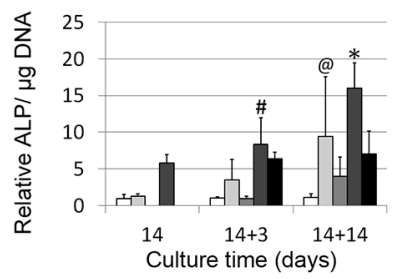

ALP activity on ES-scaffolds

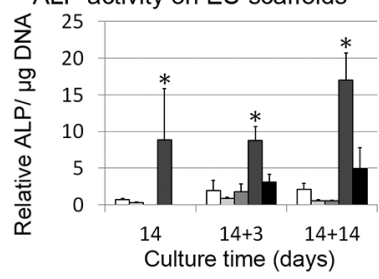

GAG production on FDM-scaffolds

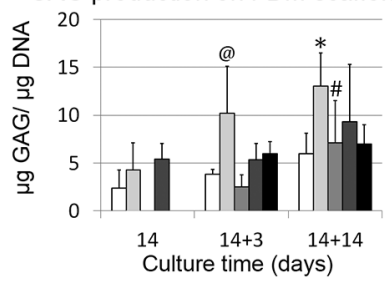

GAG production on ES-scaffolds

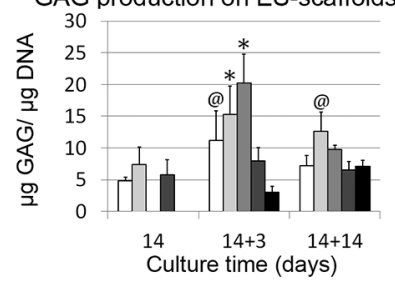

Figure 6.6: (A) RT-QPCR results after 14 days of soluble-factor-induced differentiation followed by 3 or 14 days of de-differentiation. ALP gene expression on FDM-scaffolds significantly increased in OM after 14, 17 and 28 days in both scaffold types compared to the levels for BM after 14 days of culture. After 14 days of de-differentiation, there was no significant difference between $\mathrm{BM}$ and $\mathrm{OB}$, whereas $\mathrm{OM}$ remained up-regulated. In FDM-scaffolds a significant increase in Sox9 expression was found only after 17 days of culture in CM, whereas in ES-scaffolds a significant down-regulation was found after 28 days in CM. In CB no differences were observed after 3 days or 14 days of de-differentiation compared to BM after 14 days of culture. Collagen-1 and collagen-2 expression was slightly or in some conditions even significantly up-regulated after 17 days of culture, whereas a down-regulation was found in all conditions after 28 days of culture. (B) ALP activity showed an up-regulation in OM over time as observed before, yet the ALP activity in OB did not change in FDM-scaffolds compared to OM at day 14. In ES-scaffolds the ALP activity was decreased compared to OM at day 14. GAG expression showed a significant up-regulation in CM after 17 and 28 days of culture in both scaffold types. In CB this up-regulation showed to be even higher after 17 days on ES-scaffolds whereas a decrease in GAG production was found in FDM-scaffolds at the same time-point. (A: $\mathrm{n}=5, \mathrm{~B}: \mathrm{n}=4, \# \mathrm{p}<0.05$, @ $\mathrm{p}<0.01,{ }^{*} \mathrm{p}<0.001$, Dunnett's posttest with BM 3D of respective scaffold type day 14 as control) 
3 days or 14 days of de-differentiation compared to BM after 14 days of culture. Similarly as to the results presented in Figure 6.3, collagen-1 and collagen- 2 expression showed the same trends per scaffold type. In both scaffold types, collagen-1 and collagen-2 expression was slightly or in some conditions even significantly up-regulated after 17 days of culture, whereas a down-regulation was found in all conditions after 28 days of culture.

The stability of mRNA expression levels after differentiation was also assessed for donor 2 on FDM-scaffolds, for donor 3 on ES-scaffolds and for donor 4 on FDMscaffolds (Supplementary Figures 6.9, 6.10 and 6.11, respectively). In the FDMscaffolds, it was observed that Sox9, collagen-1 and collagen-2 generally showed similar trends per donor, which was also observed for donor 1 on FDM-scaffolds. There seemed to be no correlation between the gene expression of ALP, ACAN and ALCAM per donor. Donor 2 and 4 did not show a consistent positive correlation between ALP gene expression and the presence of OM. Also for the markers of chondrogenesis, Sox9, ACAN and collagen-2, no positive correlation was found between gene expression levels and the presence of CM. For donor 3 hMSCs on ES-scaffolds, ALP was significantly down-regulated in most of the conditions compared to BM day 14. Only after 14 days of de-differentiation after osteogenic differentiation, the gene expression levels were restored to comparable levels as for hMSCs in BM after 14 days of culture. Sox9 and ACAN showed a consistent but not significant down-regulation in CM compared to BM at day 14 on ES-scaffolds. Also this down-regulation was lost during the de-differentiation phase.

To investigate the functional response of hMSCs upon de-differentiation, protein expression levels were analyzed (Figure 6.6B). BM, CM and OM results after 14 and 28 days of culture are based on the same results as presented in Figure 6.4. ALP activity in OM showed an up-regulation over time as observed before, yet the ALP activity in OB did not change in FDM-scaffolds compared to OM at day 14. In ESscaffolds, the ALP activity was even decreased compared to OM at day 14 and showed no significant difference with BM at day 14. GAG expression showed a significant up-regulation in CM after 17 and after 28 days of culture in both scaffold types. In $\mathrm{CB}$, this up-regulation showed to be even higher after 17 days on ES-scaffolds whereas a decrease in GAG production was found in FDM-scaffolds at the same time-point. After 14 days of de-differentiation the GAG production was significantly increased in CB compared to BM at day 14, yet the GAG expression was lower than for CM after 28 days of culture. Figure S6.12 shows the protein expression levels for donor 2 and 4 on FDM-scaffolds and for donor 3 on ES-scaffolds. It can be observed that only donor 2 and 3 hMSCs showed a significant increase in ALP activity when cultured in $\mathrm{OM}$, and this activity is lost upon soluble factor removal. For donor 4, a significant up-regulation was found in $\mathrm{OB}$ after 3 days of de-differentiation compared to 14 days of differentiation. There was, however, no significant difference between OM and OB for donor 4 after 3 or 14 days of de-differentiation. With respect to GAG production, only donor 4 showed a response on CM, whereas for the other 2 donors no profound changes in GAG production were found. In just a few of the cases where a change in the protein production levels was observed for heterogeneous populations of hMSCs after differentiation, de-differentiation resulted in a decrease of these protein production levels. For colony-picked hMSCs, this effect of the de-differentiation phase 
on protein production levels was found to be much stronger.

\subsection{Discussion}

Several studies have reported on hMSCs differentiation potential when cultured on $3 \mathrm{D}$ scaffolds with or without the addition of soluble factors. However, as far as we know, the stability of the differentiated phenotype after in vitro culture is not assessed thoroughly. In many tissue engineering applications, scaffolds cultured in vitro with hMSCs ultimately have to be implanted in a defect site. Therefore, it is of high importance to assess whether the results achieved in vitro have the potential to be maintained upon implantation.

Differentiation towards the osteogenic and chondrogenic lineage in this study was induced by the introduction of well-known soluble factors in the culture media. BM served as a negative control on differentiation, assuming that similar as in $2 \mathrm{D}$ also in $3 \mathrm{D}$ no differentiation will be induced by the media components. The three different scaffolds types did not seem to change the cellular phenotype of colony-picked hMSCs towards the osteogenic or chondrogenic lineage without the presence of differentiation media. In BM, there were no significant differences in mRNA expression levels in any of the three systems for ALP, Sox9, collagen-1 and collagen-2 after 3, 7, 14, 21 or 28 days of culture compared to the control group in BM in 2D after 1 day of culture. Also ALP activity and GAG production did not show consistent significant changes over time for hMSCs in BM in any of the scaffold systems. The same was found for two out of three of more heterogeneous hMSCs populations. Only the heterogeneous population of hMSCs from donor 3 showed significant differences between mRNA expression levels after 1 day of culture in BM in 2D and after 3 days of culture in BM on ES-scaffolds. Yet, these changes in expression levels did not change further over time in BM for the majority of genes that were tested. From these results, it can be concluded that all three scaffold-types did not induce osteogenic or chondrogenic differentiation in both colony-picked hMSCs and in the more heterogeneous populations of hMSCs in the absence of differentiation inducing soluble factors.

To assess whether these scaffolds support hMSCs differentiation, the differentiation towards osteogenic and chondrogenic lineage was assessed using the previous mentioned soluble factors. As an indication of osteogenic differentiation capacity, all three scaffolds systems showed an up-regulation of ALP expression and ALP activity over time when the colony-picked hMSCs were cultured in OM with fold increases comparable to the levels observed in 2D over time. This soluble-factor-induced change in cellular phenotype was partly lost when OM was replaced by BM after 14 days of differentiation which again gave the impression that the scaffolds did not induce but also did not promote hMSCs differentiation towards the osteogenic lineage.

The induced chondrogenic response on $\mathrm{CM}$ in $2 \mathrm{D}$ culture was not as profound as the osteogenic response on OM. Sox9, an early marker for chondrogenesis, did not consistently increase over time. In contrast, in 2D it showed a direct decrease in all three media formulations. In 3D a positive correlation between CM and Sox9 gene expression was only found in FDM-scaffolds. The response on CM with respect to the production of GAG was found to be the strongest in most consistent for hMSCs cultured on the micro-objects. A down-regulation of Sox9 in combination with an 
up-regulation of osteogenic markers was observed in $\mathrm{OM}$ both in 2D and in 3D and could be associated with differentiation into the osteogenic lineage [39].

During culture by microscopy observation and after culture by SEM analysis, it was observed that the number of cells both in micro-mass culture and in FDMscaffolds in CM decreased over time. Although this difference in cell adherence was not found to the same extend for all donors, probably as an effect of donor variation, the lack of cells in CM for some of the donors could be caused by the absence of FBS in the media which is known to act as a cell-adherence mediator. Conversely, hMSCs cultured in CM on ES-scaffolds and on micro-objects showed DNA quantities comparable to the DNA quantities of samples cultured in BM or OM at all timepoints for both the colony-picked hMSCs and the hMSCs from donor 3. Besides donor variation, the differences in cell adherence for hMSCs cultured in CM on ES- scaffolds or micro-objects and on FDM-scaffolds could be a result from both the physical properties of the scaffold types (FDM vs electrospun) and the scaffold material (FDM vs micro-objects).

A negative response in Sox9, collagen-2 and ACAN was found for hMSCs from donor 3 cultured in CM on ES-scaffolds. The differentiation potential towards the chondrogenic lineage for this heterogeneous population of hMSCs cultured in micromasses could not be assessed since the quantities of isolated RNA were too low to run further analysis. For this donor, it could be concluded that these hMSCs lack differentiation potential towards the chondrogenic lineage under traditional chondrogenesis inducing culture conditions. ES-scaffolds might still be favorable as 3D support for chondrogenic differentiation, in case the hMSC population of interest shows a high potential to differentiate into the chondrogenic lineage in micro-mass culture. Low RNA quantities were not observed for the micro-mass cultures of the other donors and hence could be an effect of donor variation [34, 40]. In summary, gene expression levels for colony-picked hMSCs showed a more profound response to osteogenic factors than the hMSCs from the other donors, probably due to the heterogeneity of those hMSCs populations,. Furthermore, colony-picked hMSCs showed a positive correlation between ALP gene expression levels and ALP activity as well as between Sox9 gene expression and GAG production. For the more heterogeneous populations of hMSCs a positive and consistent response on differentiation inducing factors was only found in protein expression. Yet, the use of these heterogeneous populations of hMSCs from older patients is more clinically relevant since in future therapies pre-selection of hMSCs might be too costly and time-consuming.

With respect to de-differentiation, generally, it was observed that when hMSCs showed a positive response on $\mathrm{CM}$ or $\mathrm{OM}$ towards the chondrogenic or osteogenic lineage, respectively, the differentiated phenotype was lost within 3 or 14 days after soluble factor removal. Both the response on differentiation inducing factors and the loss of the differentiated phenotype upon de-differentiation was found to be stronger in colony-picked hMSCs than in hMSCs from donor 2, 3 and 4. From these results, it can be concluded that the potentially soluble-factor-induced differentiated phenotype of colony-picked hMSCs showed to be unstable. The phenotypic stability of more heterogeneous populations of hMSCs also showed to be limited, since the increased protein expression levels were lost upon soluble factor removal for most of the conditions similarly to the results for colony-picked hMSCs. 
With the results presented herein, we would like to emphasize that for future in vitro tissue engineering it is important to bear in mind that successful soluble factor induced differentiation of any population of hMSCs does not necessarily result in a stable commitment of the hMSCs to the targeted lineage. Therefore, the development of differentiation inductive scaffolds that will retain their intrinsic instructive cues over long time-periods could be vital for future tissue engineering applications.

\subsection{Conclusion}

To the best of our knowledge this is the first study where the soluble-factor-induced differentiation of hMSCs is assessed for its stability on three distinct scaffold types and compared to their differentiation capacity in 2D. Firstly, we showed that solublefactor-induced differentiation was neither inhibited nor promoted by the scaffolds' properties which makes them suitable non-inductive supports for several tissue engineering applications. Secondly, after soluble factor removal, the possibly differentiated phenotype of the hMSCs was found to be lost and the mRNA expression levels of the majority of the assessed genes returned to comparable levels as for hMSCs that were cultured in non-inductive media during the full time-period of the study. From these results, we conclude that although some scaffold types might be opted as promising candidates to support hMSCs differentiation and tissue growth, these scaffolds do not always guarantee a stable differentiated phenotype. In future tissue engineering approaches, when combining scaffolds with hMSCs to be differentiated into a certain lineage in vitro, the stability of the differentiation phenotype should be assessed to better predict the constructs functionality upon implantation.

\section{Acknowledgements}

The authors gratefully acknowledge the funding from the Netherlands Institute for Regenerative Medicine (NIRM) through the grant number FES0908. Some of the materials employed in this work were provided by the Texas A \& M Health Science Center College of Medicine Institute for Regenerative Medicine at Scott \& White through a grant from NCRR of the NIH (Grant \# P40RR017447). 


\section{References}

[1] Ma B, Leijten JCH, Wu L, Kip M, van Blitterswijk CA, Post JN, et al. Gene expression profiling of dedifferentiated human articular chondrocytes in monolayer culture. Osteoarthr Cartilage. 2013;21:599-603.

[2] Kluba T, Niemeyer T, Gaissmaier C, Grunder T. Human anulus fibrosis and nucleus pulposus cells of the intervertebral disc - Effect of degeneration and culture system on cell phenotype. Spine. 2005;30:2743-8.

[3] Kayali AG, Flores LE, Lopez AD, Kutlu B, Baetge E, Kitamura R, et al. Limited capacity of human adult islets expanded in vitro to redifferentiate into insulin-producing beta-cells. Diabetes. 2007;56:703-8.

[4] Buzhor E, Harari-Steinberg O, Omer D, Metsuyanim S, Jacob-Hirsch J, Noiman T, et al. Kidney Spheroids Recapitulate Tubular Organoids Leading to Enhanced Tubulogenic Potency of Human Kidney-Derived Cells. Tissue Eng Pt A. 2011;17:2305-19.

[5] Lee K, Majumdar MK, Buyaner D, Hendricks JK, Pittenger MF, Mosca JD. Human mesenchymal stem cells maintain transgene expression during expansion and differentiation. Mol Ther. 2001;3:85766.

[6] Pittenger MF, Mackay AM, Beck SC, Jaiswal RK, Douglas R, Mosca JD, et al. Multilineage potential of adult human mesenchymal stem cells. Science. 1999;284:143-7.

[7] Mackay AM, Beck SC, Murphy JM, Barry FP, Chichester CO, Pittenger MF. Chondrogenic differentiation of cultured human mesenchymal stem cells from marrow. Tissue Eng. 1998;4:415-28.

[8] DiGirolamo CM, Stokes D, Colter D, Phinney DG, Class R, Prockop DJ. Propagation and senescence of human marrow stromal cells in culture: a simple colony-forming assay identifies samples with the greatest potential to propagate and differentiate. Brit J Haematol. 1999;107:275-81.

[9] Menicanin D, Bartold PM, Zannettino AC, Gronthos S. Genomic profiling of mesenchymal stem cells. Stem cell reviews. 2009;5:36-50.

[10] Dominici M, Le Blanc K, Mueller I, Slaper-Cortenbach I, Marini FC, Krause DS, et al. Minimal criteria for defining multipotent mesenchymal stromal cells. The International Society for Cellular Therapy position statement. Cytotherapy. 2006;8:315-7.

[11] Rasini V, Dominici M, Kluba T, Siegel G, Lusenti G, Northoff H, et al. Mesenchymal stromal/stem cells markers in the human bone marrow. Cytotherapy. 2013;15:292-306.

[12] Abrahamsson CK, Yang F, Park H, Brunger JM, Valonen PK, Langer R, et al. Chondrogenesis and mineralization during in vitro culture of human mesenchymal stem cells on three-dimensional woven scaffolds. Tissue engineering. 2010;16:3709-18.

[13] Hu J, Feng K, Liu X, Ma PX. Chondrogenic and osteogenic differentiations of human bone marrow-derived mesenchymal stem cells on a nanofibrous scaffold with designed pore network. Biomaterials. 2009;30:5061-7.

[14] Silva JM, Georgi N, Costa R, Sher P, Reis RL, Van Blitterswijk CA, et al. Nanostructured 3D constructs based on chitosan and chondroitin sulphate multilayers for cartilage tissue engineering. Plos One. 2013;8:e55451.

[15] Nguyen LTH, Liao S, Chan CK, Ramakrishna S. Enhanced osteogenic differentiation with 3D electrospun nanofibrous scaffolds. Nanomedicine-Uk. 2012;7:1561-75.

[16] Barradas AM, Monticone V, Hulsman M, Danoux C, Fernandes H, Tahmasebi Birgani Z, et al. Molecular mechanisms of biomaterial-driven osteogenic differentiation in human mesenchymal stromal cells. Integr Biol (Camb). 2013;5:920-31.

[17] Nandakumar A, Birgani ZT, Santos D, Mentink A, Auffermann N, van der Werf K, et al. Surface modification of electrospun fibre meshes by oxygen plasma for bone regeneration. Biofabrication. $2013 ; 5$.

[18] Shakhbazau AV, Petyovka NV, Kosmacheva SM, Potapnev MP. Neurogenic induction of human mesenchymal stem cells in fibrin 3D matrix. Bulletin of experimental biology and medicine. 2011;150:547-50.

[19] Janeczek Portalska K, Leferink A, Groen N, Fernandes H, Moroni L, van Blitterswijk C, et al. 
Endothelial differentiation of mesenchymal stromal cells. Plos One. 2012;7:e46842.

[20] Tian H, Bharadwaj S, Liu Y, Ma H, Ma PX, Atala A, et al. Myogenic differentiation of human bone marrow mesenchymal stem cells on a 3D nano fibrous scaffold for bladder tissue engineering. Biomaterials. 2010;31:870-7.

[21] Discher DE, Mooney DJ, Zandstra PW. Growth factors, matrices, and forces combine and control stem cells. Science. 2009;324:1673-7.

[22] Engler AJ, Sen S, Sweeney HL, Discher DE. Matrix elasticity directs stem cell lineage specification. Cell. 2006;126:677-89.

[23] Discher DE, Janmey P, Wang YL. Tissue cells feel and respond to the stiffness of their substrate. Science. 2005;310:1139-43.

[24] Unadkat HV, Hulsman M, Cornelissen K, Papenburg BJ, Truckenmuller RK, Carpenter AE, et al. An algorithm-based topographical biomaterials library to instruct cell fate (vol 108, pg 16565, 2011). PNAS. 2012;109:5905.

[25] McBeath R, Pirone DM, Nelson CM, Bhadriraju K, Chen CS. Cell shape, cytoskeletal tension, and RhoA regulate stem cell lineage commitment. Dev Cell. 2004;6:483-95.

[26] Stevens MM, George JH. Exploring and engineering the cell surface interface. Science. 2005;310:1135-8.

[27] Decuzzi P, Ferrari M. Modulating cellular adhesion through nanotopography. Biomaterials. 2010;31:173-9.

[28] Zhang L, Peng LP, Wu N, Li LP. Development of bone marrow mesenchymal stem cell culture in vitro. Chinese Med J-Peking. 2012;125:1650-5.

[29] Schilling T, Noth U, Klein-Hitpass L, Jakob F, Schutze N. Plasticity in adipogenesis and osteogenesis of human mesenchymal stem cells. Mol Cell Endocrinol. 2007;271:1-17.

[30] Grove JE, Bruscia E, Krause DS. Plasticity of bone marrow-derived stem cells. Stem Cells. 2004;22:487-500.

[31] Oreffo RO, Cooper C, Mason C, Clements M. Mesenchymal stem cells: lineage, plasticity, and skeletal therapeutic potential. Stem cell reviews. 2005;1:169-78.

[32] Rottmar M, Hakanson M, Smith M, Maniura-Weber K. Stem cell plasticity, osteogenic differentiation and the third dimension. J Mater Sci-Mater M. 2010;21:999-1004.

[33] Song L, Tuan RS. Transdifferentiation potential of human mesenchymal stem cells derived from bone marrow. Faseb J. 2004;18:980-2.

[34] Phinney DG, Kopen G, Righter W, Webster S, Tremain N, Prockop DJ. Donor variation in the growth properties and osteogenic potential of human marrow stromal cells. Journal of Cellular Biochemistry. 1999;75:424-36.

[35] de Bruijn JD, van den Brink I, Mendes S, Dekker R, Bovell YP, van Blitterswijk CA. Bone induction by implants coated with cultured osteogenic bone marrow cells. Advances in dental research. 1999;13:74-81.

[36] Moroni L, de Wijn JR, van Blitterswijk CA. Three-dimensional fiber-deposited PEOT/PBT copolymer scaffolds for tissue engineering: influence of porosity, molecular network mesh size, and swelling in aqueous media on dynamic mechanical properties. Journal of biomedical materials research. 2005;75:957-65.

[37] Leferink A, Schipper D, Arts E, Vrij E, Rivron N, Karperien M, et al. Engineered Micro-Objects as Scaffolding Elements in Cellular Building Blocks for Bottom-Up Tissue Engineering Approaches. Adv Mater. 2014;26:2592-9

[38] Siegel G, Kluba T, Hermanutz-Klein U, Bieback K, Northoff H, Schafer R. Phenotype, donor age and gender affect function of human bone marrow-derived mesenchymal stromal cells. Bmc Med. $2013 ; 11$.

[39] Giuliani N, Lisignoli G, Magnani M, Racano C, Bolzoni M, Dalla Palma B, et al. New insights into osteogenic and chondrogenic differentiation of human bone marrow mesenchymal stem cells and their potential clinical applications for bone regeneration in pediatric orthopaedics. Stem cells international. 2013;2013:312501. 
[40] Siddappa R, Licht R, van Blitterswijk C, de Boer J. Donor variation and loss of multipotency during in vitro expansion of human mesenchymal stem cells for bone tissue engineering. Journal of orthopaedic research : official publication of the Orthopaedic Research Society. 2007;25:1029-41. 
Supplementary Information
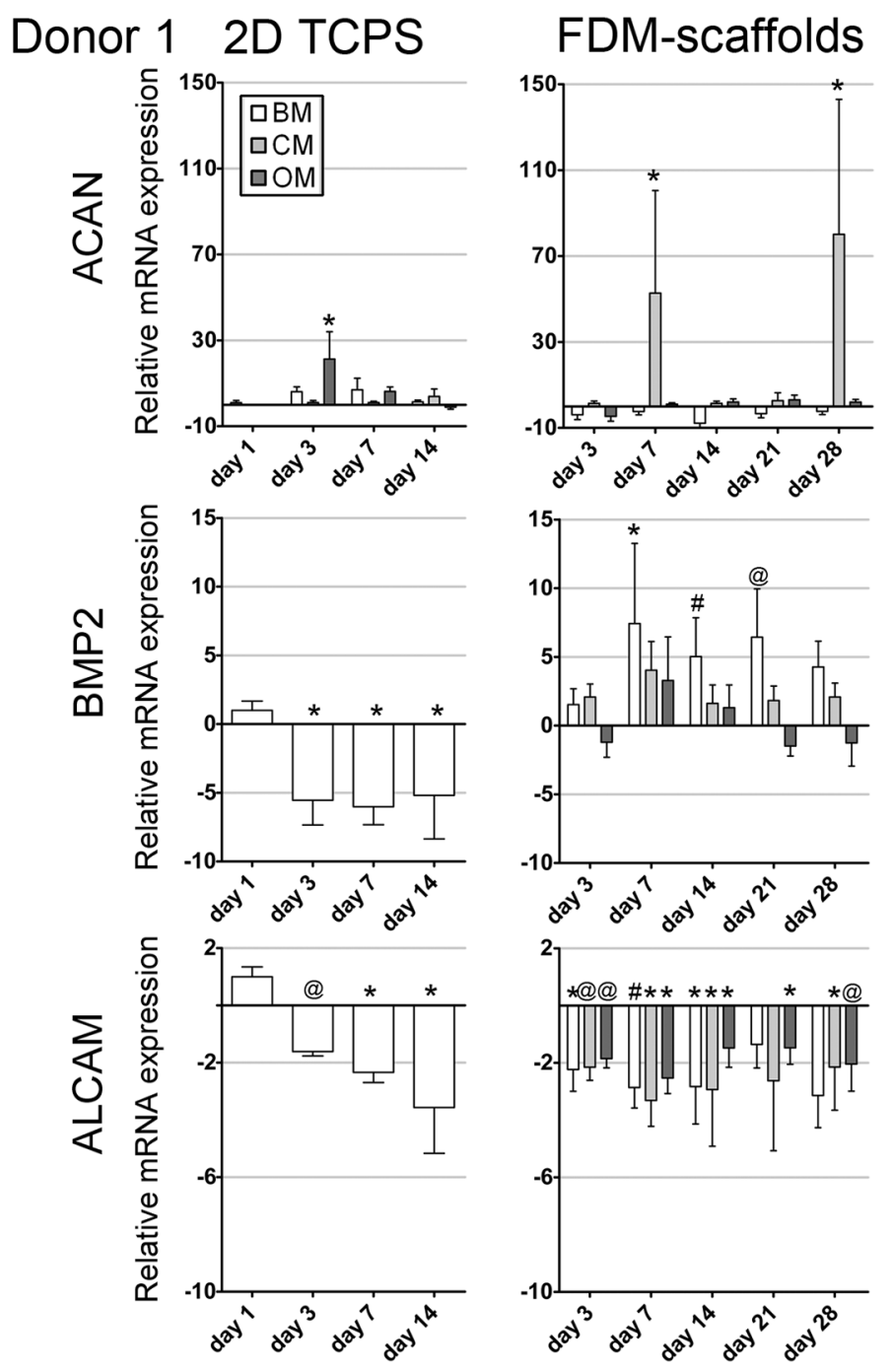

Figure S6.1. Soluble-factor-induced differentiation of colony-picked hMSCs in 2D as monolayer $(\mathrm{BM}$ and $\mathrm{OM})$ or micromass culture $(\mathrm{CM})$ and in 3D on FDM-scaffolds was assessed for ACAN, ALCAM and BMP2 mRNA expression levels. In micromass culture no activation of ACAN was found upon culture in CM. On FDM-scaffolds, culture in CM resulted in a significant up-regulation of ACAN after 7 and 28 days of culture. BMP2 showed a significant down-regulation in 2D after 3, 7 and 14 days in BM and a significant up-regulation in 3D after 7, 14 and 21 days in BM. ALCAM was significantly down-regulated in all conditions for nearly all time-points. ( $\mathrm{n}=5$, except for ACAN in CM day $28 \mathrm{n}=4, \# \mathrm{p}<0.05$, @ $\mathrm{p}<0.01$, * $\mathrm{p}<0.001$, Dunnett's posttest with BM 2D day 1 as control) 


\section{Donor 2 Gene expression in 2D on TCPS}
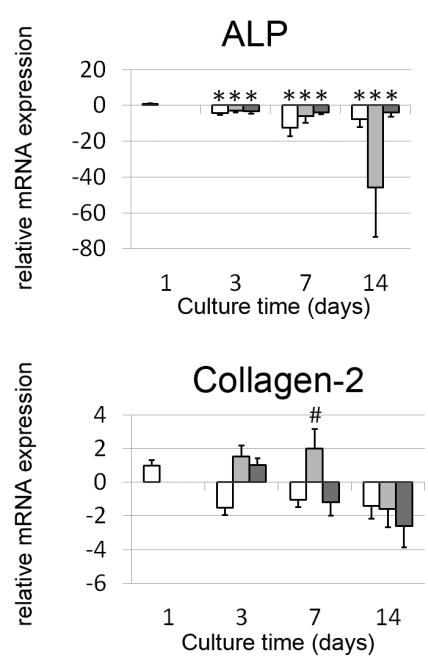

Sox9

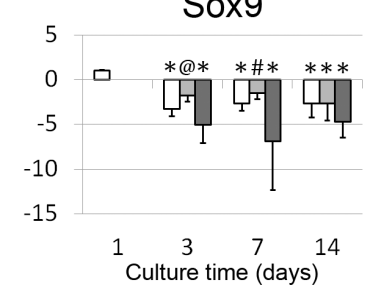

ACAN

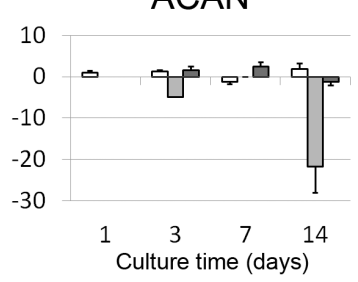

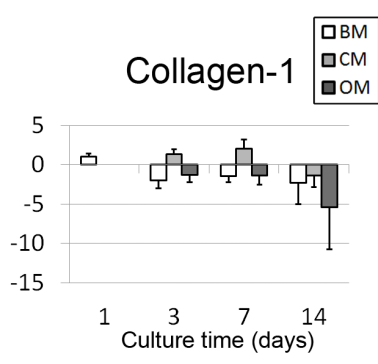

ALCAM

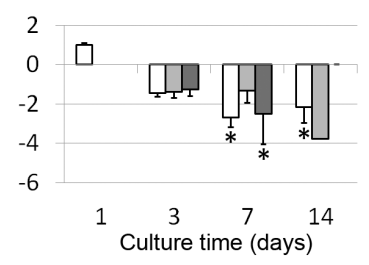

Figure S6.2. Soluble factor induced differentiation of hMSCs from donor 2 in 2D on TCPS. ALP, Sox9 and ALCAM expression levels were significantly down-regulated in all three types of media. Collagen-1 and collagen-2 expression followed similar trends in which initially a small up-regulation in CM and a down-regulation at nearly all time-points in BM and OM was found. ACAN expression was in some samples in CM too low to be detected. Some samples showed too low expression levels of ACAN and ALCAM expression to be detected within a reliable range of CT-values and were therefore not presented. ( $\mathrm{n}=5$, except for ACAN in CM day $3(n=1)$, day $7(n=0)$, day $14(n=2)$ and ALCAM in CM day $14(n=1)$ and $\mathrm{OM}$ day 14 (not expressed) \# p $<0.05$, @ p $<0.01$, ${ }^{*} \mathrm{p}<0.001$, Dunnett's posttest with BM 2D day 1 as control) 
Donor 4 Gene expression in 2D on TCPS
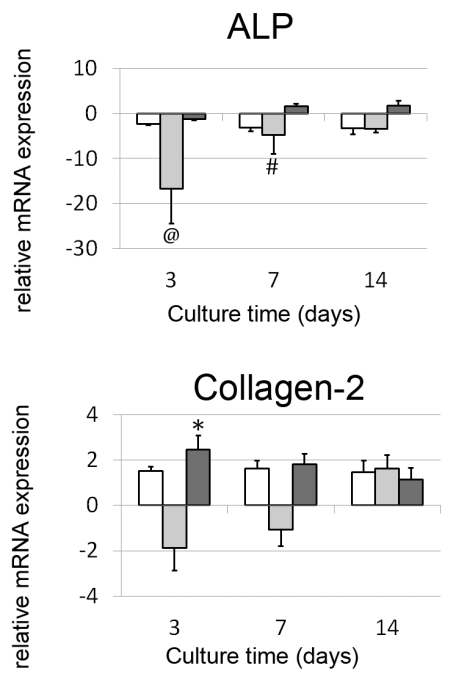

Sox 9

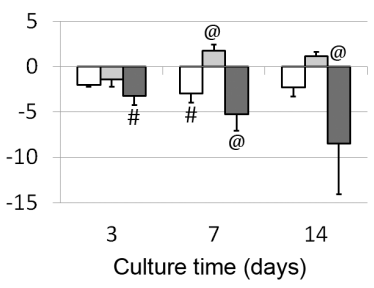

ACAN

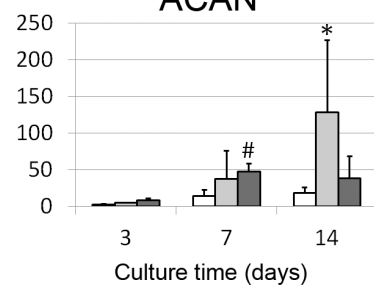

Collagen-1

$\square \mathrm{BM}$

$\square \mathrm{CM}$

$\square \mathrm{OM}$

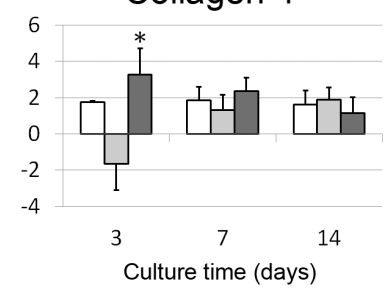

ALCAM

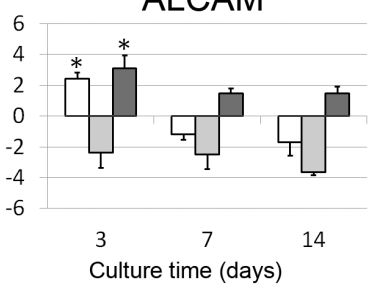

Figure S6.3. Soluble factor induced differentiation of hMSCs from donor 4 in 2D on TCPS. ALP expression levels were initially significantly down-regulated in CM. Sox9 was significantly down-regulated after 7 days in BM and after 3 and 7 days in OM. Collagen-1 and collagen-2 expression followed similar trends in which there was initially a small downregulation in $\mathrm{CM}$ and an up-regulation at day 3 in OM. ACAN expression showed a significant up-regulation in CM after 14 days of culture. ( $\mathrm{n}=5, \# \mathrm{p}<0.05, @ \mathrm{p}<0.01, * \mathrm{p}<0.001$, Dunnett's posttest with BM 2D day 1 as control) 


\section{Donor 2 Gene expression in 3D on FDM-scaffolds}
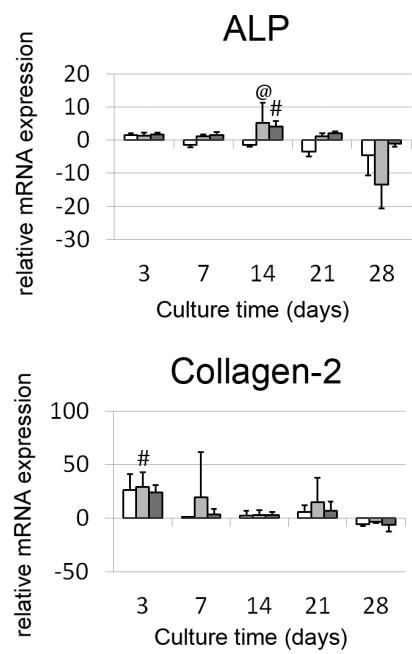

Sox9

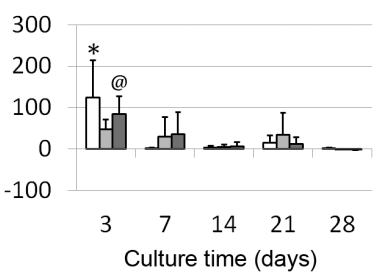

ACAN

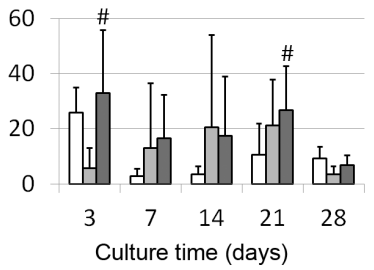

Collagen-1

口OM

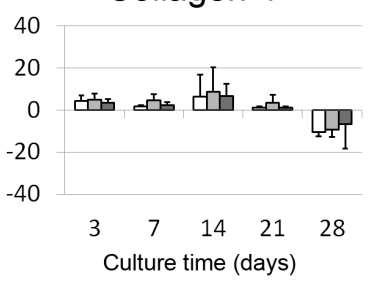

ALCAM

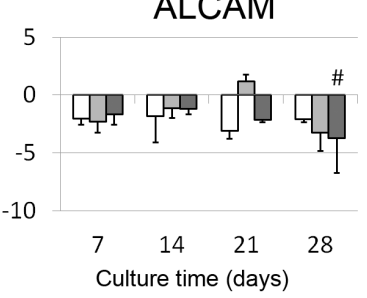

Figure S6.4. Soluble factor induced differentiation of hMSCs from donor 2 on 3D FDMscaffolds. No profound response on OM was found in the mRNA expression of the markers for osteogenesis ALP and Collagen-1. Sox9 expression was initially increased in CM, and significantly increased in BM and OM. This increase was lost after 7 days of culture. After 28 days of culture a small down-regulation was found compared to the expression levels after 1 day of culture in BM on TCPS. ACAN expression levels did not correlate to chondrogenic induction in CM. ALCAM expression levels showed a two-fold down-regulation after 7 days of culture, yet the expression levels remained stable up to 28 days of culture. ( $n=3-8$, \# $\mathrm{p}<0.05$, @ $\mathrm{p}<0.01, * \mathrm{p}<0.001$, Dunnett's posttest with BM 2D day 1 as control) 
Donor 3 Gene expression in 3D on ES-scaffolds

ALP

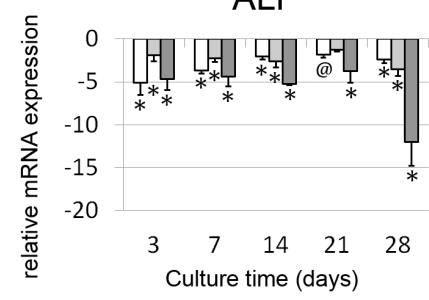

Collagen-2

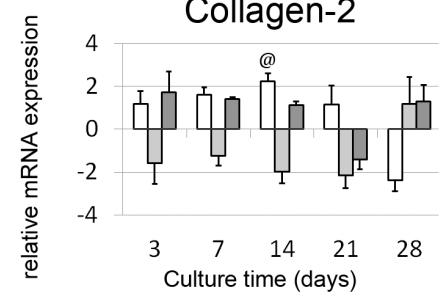

Sox9

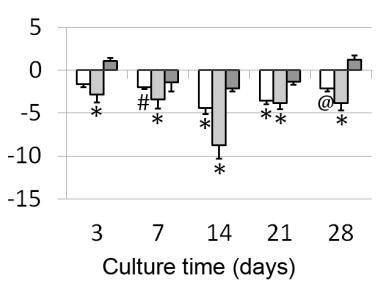

ACAN

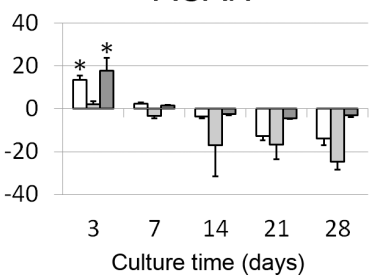

Collagen-1 $\begin{aligned} & \square \mathrm{CM} \\ & \square \mathrm{O}\end{aligned}$

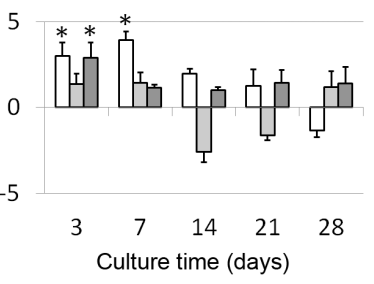

ALCAM

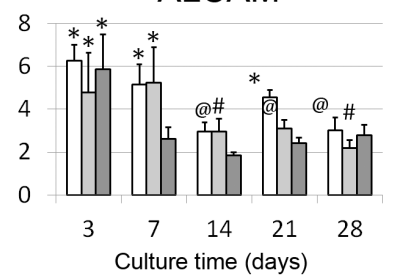

Figure S6.5. Soluble factor induced differentiation of hMSCs from donor 3 on 3D ESscaffolds. ALP and Sox9 expression levels were both significantly down-regulated in BM, $\mathrm{CM}$ and $\mathrm{OM}$ at nearly all time-points. Collagen-1 and Collagen-2 expression showed similar trends and fluctuate between a 3 -fold down and 5 fold up-regulation for Collagen- 1 and a 2-fold down- and up-regulation for collagen-2. ACAN expression levels decreased over time for all conditions. ALCAM showed to be significantly up-regulated within 3 days of 3D culture, yet the relative mRNA expression levels were slightly reduced over time. $(\mathrm{n}=5$, \# $\mathrm{p}<0.05$, @ $\mathrm{p}<0.01,{ }^{*} \mathrm{p}<0.001$, Dunnett's posttest with BM 2D day 0 as control) 

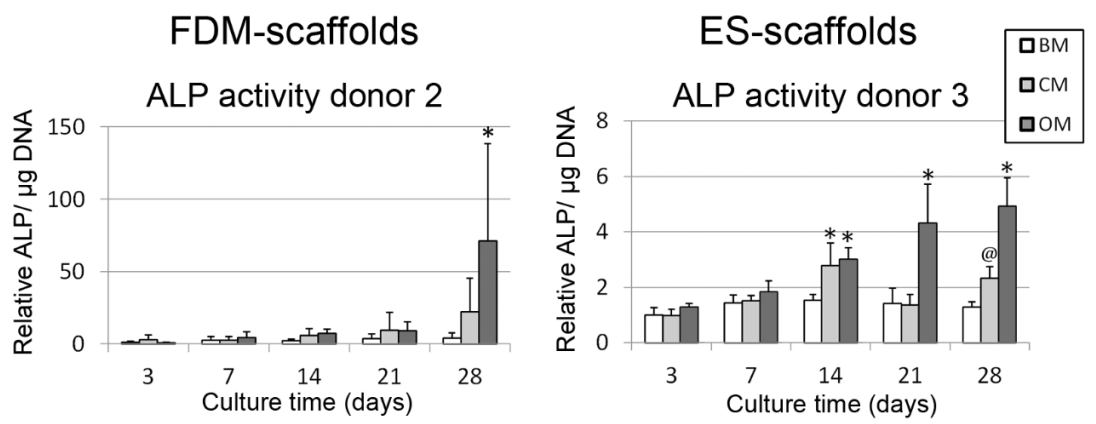

GAG production donor 2

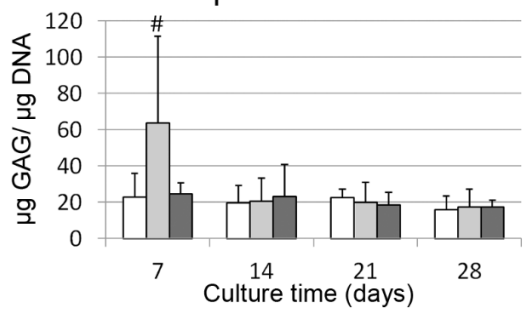

GAG production donor 3

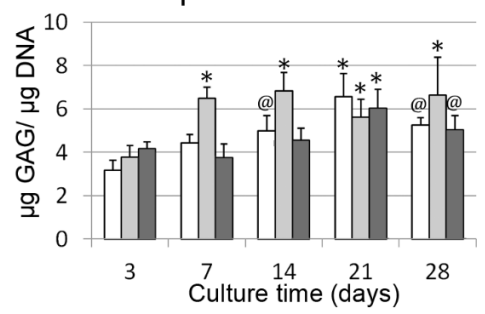

Figure S6.6. Protein expression levels after soluble factor induced differentiation of hMSCs from donor 2 and 3 in 3D on FDM- and ES-scaffolds, respectively. In both scaffold-systems an increase in ALP activity was found after culture in OM. In ES-scaffolds ALP activity was also increased after 14 and 28 days in CM. The GAG production on FDM-scaffolds only showed an increase after 7 days of culture in CM. In BM and OM no changes in GAG production were observed. The GAG production per $\mathrm{g}$ of DNA on ES-scaffolds was lower than on FDM-scaffolds due to the higher amounts of DNA detected. In CM an increase in GAG-production was found after 7 days of culture and remained stable up to day 28 . Surprisingly, also in BM and OM a significant increase in GAG-production was found after 14 and 21 days of culture respectively. $\left(\mathrm{n}=4, \# \mathrm{p}<0.05\right.$, @ $\mathrm{p}<0.01,{ }^{*} \mathrm{p}<0.001$, Dunnett's posttest with BM 2D day 3 as control for ALP donor 2, ALP donor 3 and GAG donor 3; Dunnett's posttest with BM 2D day 7 as control for GAG donor 2) 


\section{Donor 3 SEM analysis after 21 days of culture in 3D on ES-scaffolds \\ BM \\ $\mathrm{CM}$ \\ $\mathrm{OM}$}

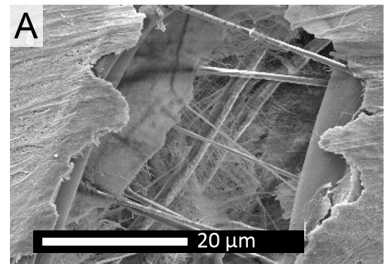

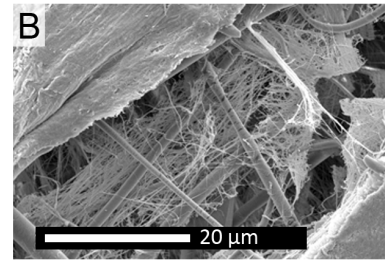

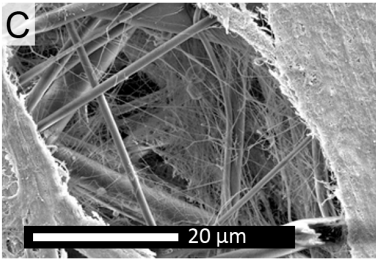

Figure S6.7. SEM analysis after 21 days of culture on ES-scaffolds. There were no differences found in the morphology and distribution of the cells and the formed tissue between scaffolds cultured with hMSCs in BM (A), CM (B) and OM (C). In all conditions a dense cellular layer was found on top of the scaffolds. On the macro-scale was observed that the majority of the ES-scaffolds wrinkled or curled-up when the hMSCs were cultured in CM.

Donor 1 SEM analysis after 28 days of culture in 3D on micro-objects $\mathrm{BM}$
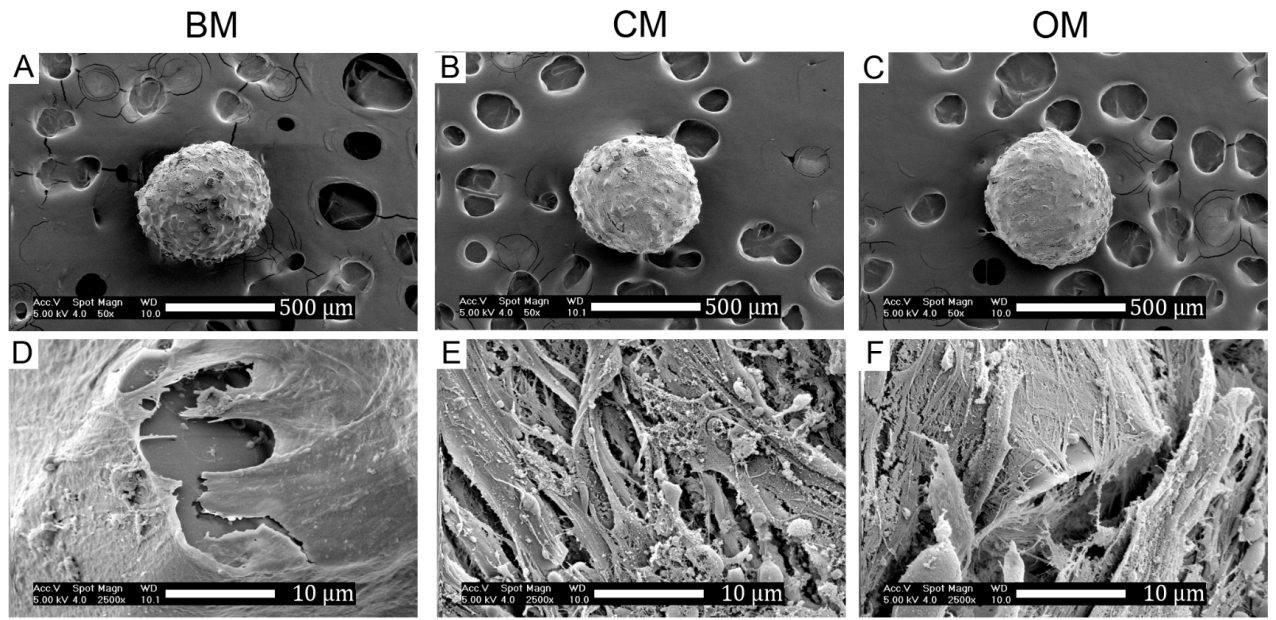

Figure S6.8. SEM analysis of colony-picked hMSCs from donor 1 after 28 days of culture in $3 \mathrm{D}$ on micro-objects. Also for micro-objects there were no differences found in the distribution of the cells and the formed tissue between micro-objects cultured with hMSCs in $\mathrm{BM}(\mathrm{A}, \mathrm{D}), \mathrm{CM}(\mathrm{B}, \mathrm{E})$ and $\mathrm{OM}(\mathrm{C}, \mathrm{F})$. However, the dense cellular layer surrounding the aggregated micro-objects appeared smoother for hMSCs cultured in BM. hMSCs cultured in CM seemed to produce more collagen-like fibers and the hMSCs in OM showed a highly spread morphology with protrusions anchoring onto the micro-objects surface. 


\section{Donor 2 Gene expression in 3D on FDM-scaffolds}

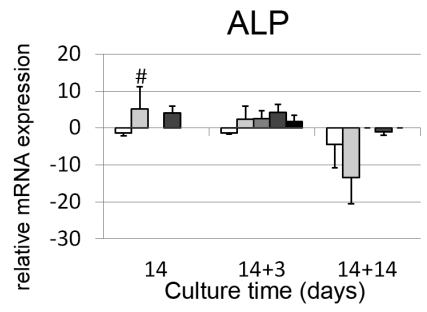

Collagen-2

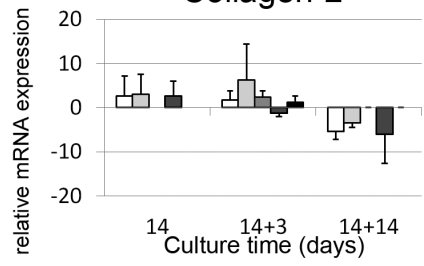

Sox9

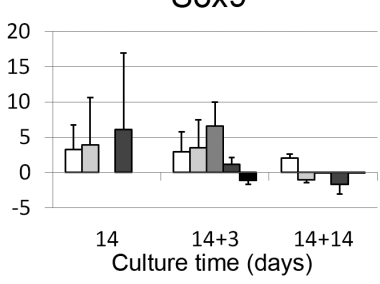

ACAN

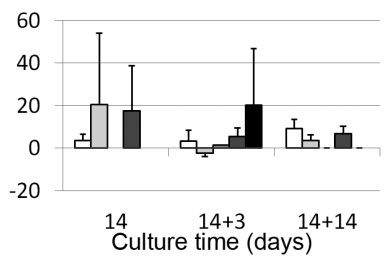

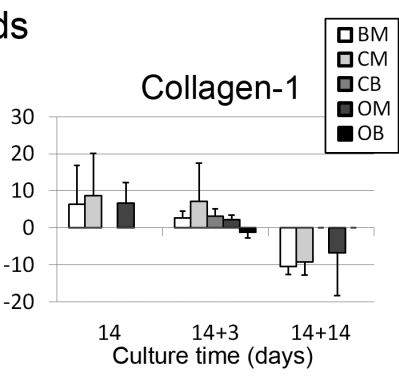

ALCAM

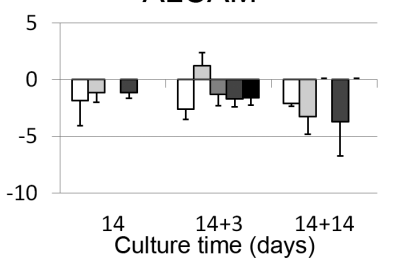

Figure S6.9. The mRNA expression levels of donor 2 hMSCs on FDM-scaffolds after 3 and 14 days of de-differentiation subsequent to 14 days of differentiation were compared to the expression levels resulting from 14 days of differentiation. ALP showed a significant upregulation after 14 days in CM. This increased expression level was lost not only after soluble factor removal $(\mathrm{CB})$ but also when culture in $\mathrm{CM}$ was continued. For all other markers no significant differences were found at day 14 between BM, CM and OM indicating that the presence of soluble factors did not result in differentiation of the hMSCs within 14 days. Therefore, no conclusions with respect to de-differentiation could be drawn for this donor on FDM-scaffolds. ( $\mathrm{n}=3-8, \# \mathrm{p}<0.05$, @ $\mathrm{p}<0.01,{ }^{*} \mathrm{p}<0.001$, Dunnett's posttest with BM 3D day 14 as control) 


\section{Donor 3 Gene expression in 3D on ES-scaffolds}

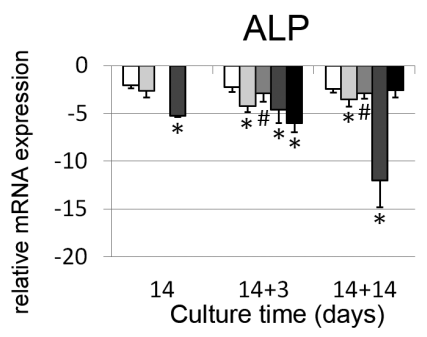

Collagen-2

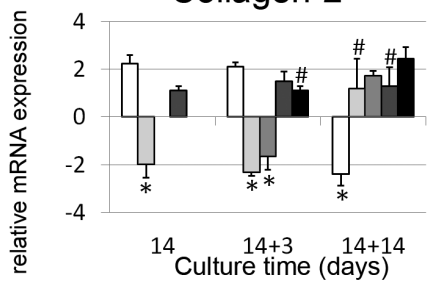

Sox 9

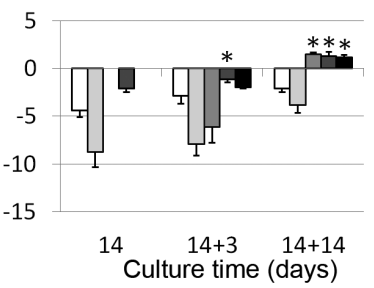

ACAN

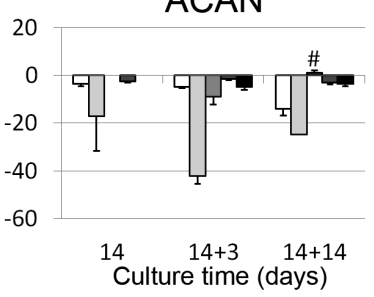

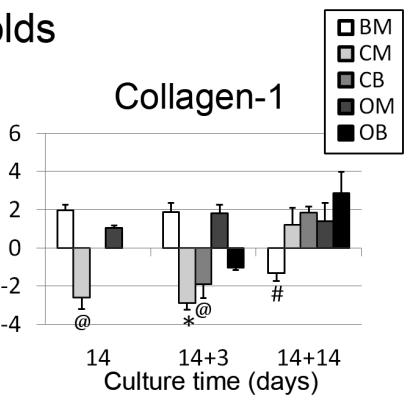

ALCAM

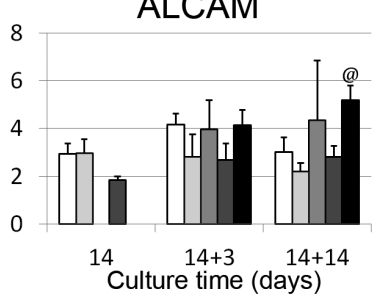

Figure S6.10. The mRNA expression levels of donor 3 hMSCs on ES-scaffolds after 3 and 14 days of de-differentiation subsequent to 14 days of differentiation were compared to the expression levels resulting from 14 days of differentiation. ALP expression levels were significantly decreased for hMSCs in OM compared to hMSCs in BM after 14 days of culture and remained to decrease over time in OM. When OM after 14 days of culture was replaced with $\mathrm{BM}(\mathrm{OB})$ it was observed that the expression levels were restored to the same levels as for hMSCs cultured in BM for 28 days. For Sox9 and ACAN expression, the same behavior was found when $\mathrm{CM}$ was replaced with $\mathrm{BM}$ after 14 days of differentiation. Collagen-1, collagen-2 and ALCAM did not show profound changes between BM, CM and OM after 14 days of differentiation and the expression levels for $\mathrm{CM}$ versus $\mathrm{CB}$ and $\mathrm{OM}$ versus $\mathrm{OB}$ remained within the same range. ( $\mathrm{n}=4-5$ except for day $14 \mathrm{OM}(\mathrm{n}=2)$ and day $14+3 \mathrm{BM}$ $(\mathrm{n}=3), \# \mathrm{p}<0.05$, @ $\mathrm{p}<0.01,{ }^{*} \mathrm{p}<0.001$, Dunnett's posttest with BM 3D day 14 as control) 


\section{Donor 4 Gene expression in 3D on FDM-scaffolds}
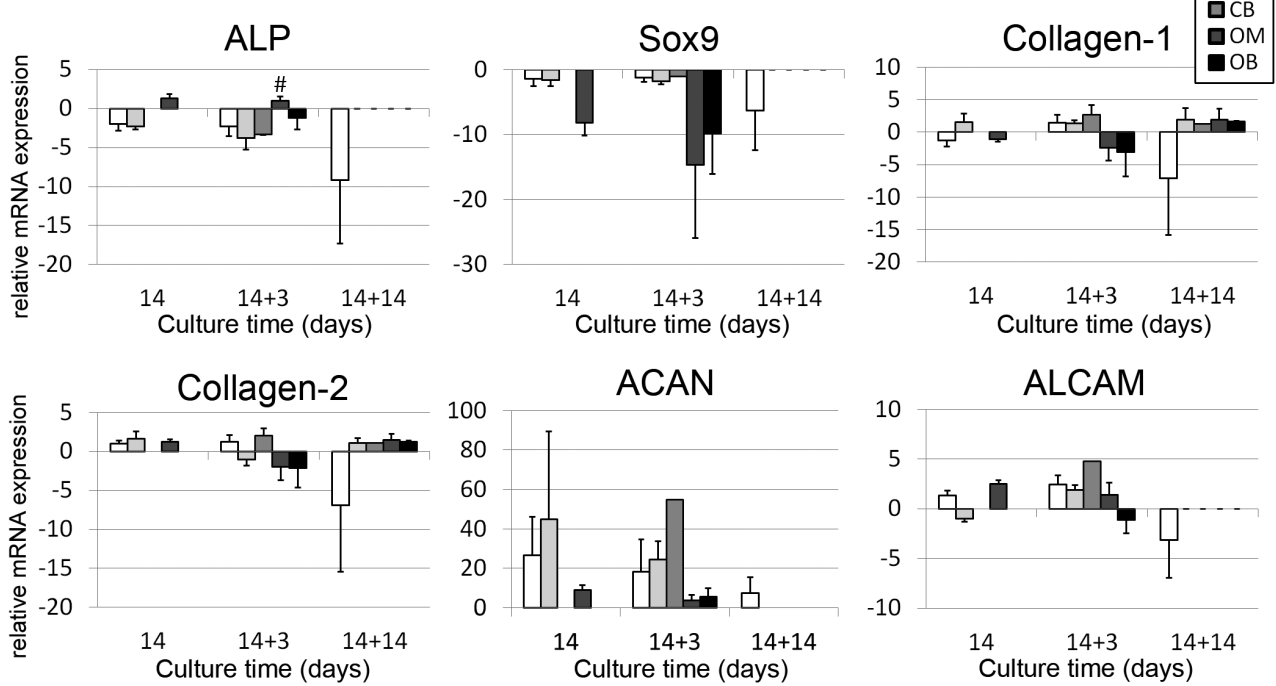

Figure S6.11. The mRNA expression levels of donor 4 hMSCs on FDM-scaffolds after 3 and 14 days of de-differentiation subsequent to 14 days of differentiation were compared to the expression levels resulting from 14 days of differentiation. ALP expression was upregulated for hMSCs in OM, after 3 days of de-differentiation the expression levels in $\mathrm{OM}$ remained stable whereas in $\mathrm{OB}$ the expression levels where down-regulated within the same range as hMSCs cultured in BM for 17 days. ALP expression levels for CM, OM, CB and OB were too low to be detected, which was also the case for the levels of Sox9, ACAN and ALCAM. Sox9 expression levels were slightly down-regulated in OM after 14 days of culture. This decrease progressed after another 3 days of differentiation while at that timepoint hMSCs in OB remained comparable to the levels in OM at day 14. Collagen-1 and collagen-2 expression showed differences between hMSCs cultured in CM or in OM. After soluble factor removal these differences were retained. For ACAN and ALCAM no profound changes in expression levels were observed between hMSCs cultured in BM, CM and OM. Therefore the maintenance of expression levels after soluble factor removal for these markers was not considered relevant. ( $\mathrm{n}=3-5$, except for day $14 \mathrm{CM}$, day $14+3 \mathrm{CB}$ and OB, day 14 +14 CM $(\mathrm{n}=2)$ and Day 28 CB $(\mathrm{n}=1), \# \mathrm{p}<0.05$, @ $\mathrm{p}<0.01,{ }^{*} \mathrm{p}<0.001$, Dunnett's posttest with BM 3D day 14 as control) 


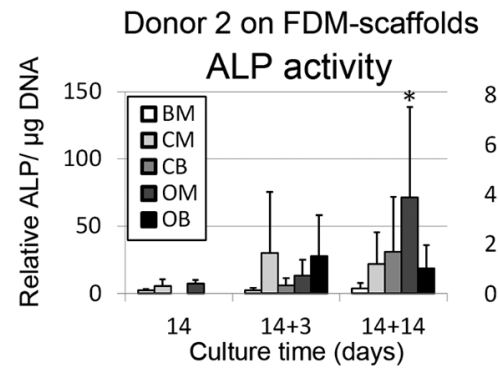

Donor 3 on ES-scaffolds

Donor 4 on FDM-scaffolds

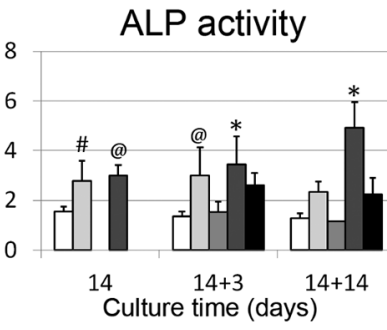

ALP activity
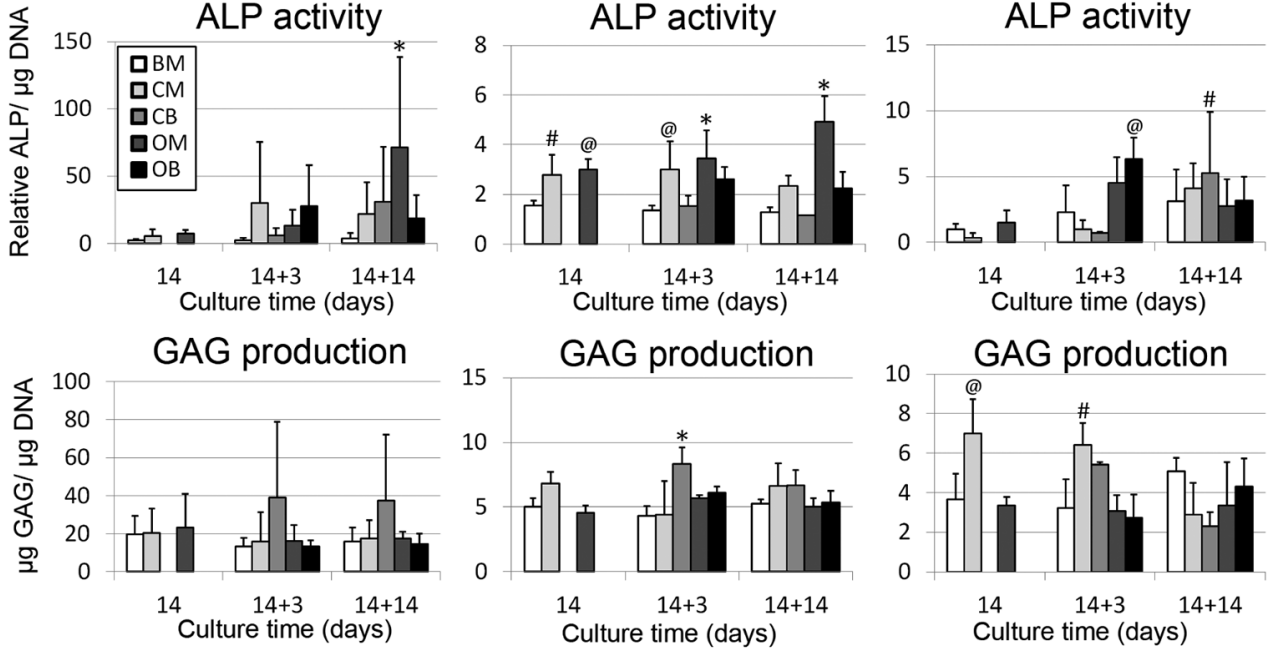

Figure S6.12. Protein expression after 3 or 14 days of de-differentiation subsequent to 14 days of differentiation in CM or OM. The ALP activity was found to be significantly increased for hMSCs cultured in OM in two out of three hMSCs populations. After 3 days of de-differentiation donor 2 hMSCs still showed an increase in ALP activity. Yet, after 14 days of de-differentiation the ALP activity in OM showed to be significantly higher than in OB. Also for hMSCs from donor 3 on ES-scaffolds, the ALP activity in OM was significantly higher than in OB after 14 days of de-differentiation. For donor 4 the ALP activity was not significantly increased in OM after 14,17 or 28 days of differentiation compared to BM at the same time-point. Only after 3 and 14 days of de-differentiation a significant increase in ALP activity was found for hMSCs in OB and CB, respectively, compared to BM day 14 . When comparing the ALP activity of hMSCs in BM, CM, OM, CB and OB after 14 days of de-differentiation, however, no differences were observed. The GAG expression levels did not change significantly for two donors. Only donor 4 on FDM-scaffolds showed an increased GAG production after hMSCs were cultured in CM. These elevated production levels were lost both when culture in CM was continued as well as for hMSCs that were de-differentiated in CB. ( $\mathrm{n}=4, \# \mathrm{p}<0.05$, @ $\mathrm{p}<0.01,{ }^{*} \mathrm{p}<0.001$, Dunnett's posttest with BM 3D day 14 as control) 


\section{Part II}

\section{Monitoring tissue engineered constructs}





\section{Chapter 7}

\section{Label-free Raman monitoring of extracellular matrix formation in three-dimensional polymeric scaffolds}

A. M. Leferink ${ }^{1 *}$, A. Kunstar ${ }^{1 *}$, P. I. Okagbare ${ }^{4}$, M. D. Morris ${ }^{4}$, Blake J. Roessler ${ }^{5}$, C. Otto ${ }^{5}$, M. Karperien $^{1,2}$, C. A. van Blitterswijk ${ }^{1}$, L. Moroni ${ }^{1}$, A. A. van Apeldoorn ${ }^{1,2}$

${ }^{1}$ Department of Tissue Regeneration and ${ }^{2}$ Present address: Department of Developmental Bioegineering and ${ }^{3}$ Department of Medical Cell Biophysics of MIRA - Institute for Biomedical Technology and Technical Medicine, University of Twente, Drienerlolaan 5, 7522 NB Enschede, The Netherlands ${ }^{4}$ Department of Chemistry, University of Michigan, 930 N. University Avenue, Ann Arbor, MI 48108, USA, ${ }^{5}$ Department of Internal Medicine, Division of Rheumatology, University of Michigan Medical School, Medical Science Research Building II, 1150 West Medical Center Drive, Room 3560, Ann Arbor, MI 48109-5688, USA

*Shared first author.

Published J R Soc Interface 10: 20130464. 


\begin{abstract}
Monitoring extracellular matrix (ECM) components is one of the key methods used to determine tissue quality in three-dimensional scaffolds for regenerative medicine and clinical purposes. Raman spectroscopy can be used for non-invasive sensing of cellular and ECM biochemistry. We have investigated the use of conventional (confocal and semi-confocal) Raman microspectroscopy and fiber-optic Raman spectroscopy for in vitro monitoring of ECM formation in three-dimensional poly(ethylene oxide terephthalate)-poly(butylene terephthalate) (PEOT/PBT) scaffolds. Chondrocyte-seeded PEOT/PBT scaffolds were analyzed for ECM formation by Raman microspectroscopy, biochemical analysis, histology and scanning electron microscopy (SEM).

ECM deposition in these scaffolds was successfully detected by biochemical and histological analysis and by label-free nondestructive Raman microspectroscopy. In the spectra collected by the conventional Raman setups the Raman bands at $937 \mathrm{~cm}^{-1}$ and at $1062 \mathrm{~cm}^{-1}$ which respectively correspond to collagen and sulfated glycosaminoglycans (sGAGs) could be used as Raman markers for ECM formation in scaffolds. Collagen synthesis was found to be different in single chondrocyte-seeded scaffolds when compared to microaggregate-seeded samples. Normalized band-area ratios for collagen content of single cell-seeded samples gradually decreased during a 21 day culture period, whereas collagen content of the microaggregate-seeded samples significantly increased during this period.

Moreover, a fiber optic Raman set-up allowed for the collection of Raman spectra from multiple pores inside scaffolds in parallel. These fiber optic measurements could give a representative average of the ECM Raman signal present in tissue engineered constructs. Results in this study provide proof-of-principle that Raman microspectroscopy is a promising non-invasive tool to monitor ECM production and remodeling in three-dimensional porous cartilage tissue engineered constructs.
\end{abstract}

Keywords: Raman spectroscopy, scaffold, extracellular matrix, imaging, chondrocytes 


\subsection{Introduction}

Articular cartilage is a highly specialized connective tissue with the function to provide a smooth and low-friction buffer between the bones of a joint and to distribute the load over the surface of joints during movement. In several pathological conditions, such as osteoarthritis and rheumatoid arthritis or trauma, cartilage shows limited capacity for regeneration due to poor cellularity and its avascular character [1, 2]. The main features of cartilage are closely related to its three-dimensional matrix, which mainly consists of collagen type-II, proteoglycans and water $[3,4]$. Therefore evaluating the production levels of these essential ECM components is a key to determine tissue quality in tissue engineered constructs. Conventional quality testing methods, such as immunohistochemistry, histology and microscopy techniques are all destructive and require tissue fixation, labeling, biochemical staining or cell lysis. In contrast, Raman microspectroscopy is a label-free technique, which does not require special sample preparation and can be used for non-invasive characterization of cell and tissue biochemistry [5]. It has been demonstrated that a careful selection of suitable laser wavelengths and intensity eliminates cell damage allowing for the study of cells without inadvertently changing their phenotype or behavior caused by photo damage $[6,7]$. This vibrational spectroscopic technique employs an inelastic scattering effect (the Raman effect) to generate a molecular fingerprint of the investigated samples based on detection of specific wavelength shifts caused by chemical bond vibrations.

Raman spectral studies have already been performed on structural analysis of collagen [8, 9], sulfated glycosaminoglycans (GAGs) and proteoglycans [10, 11]. Furthermore, this technique has been successfully applied to study collagen containing ECM in a medium-throughput culture system [12] and to monitor chondrocyte behavior on bioactive scaffolds [13]. In a fiber optic configuration, Raman spectroscopy has already been used for monitoring tissues in joints in vivo [14] and to investigate the process of bone graft incorporation in bone reconstruction and repair in a transcutaneous manner [15]. Other researchers have reported on in vivo measurements from the bladder and prostate [16], oesophagus [17], skin [18], cervix [19, 20], and arteries using Raman spectroscopy [21].

In this study, we have investigated the use of label-free Raman microspectroscopy to detect ECM formation and to monitor the production levels of essential ECM components over time in three-dimensional (3D) porous PEOT/PBT scaffolds using conventional and fiber optic Raman setups. Previously, PEOT/PBT copolymers have been extensively studied and proven to be suitable for their use as scaffold material in tissue engineering, both in vitro and in vivo [22-25], and reached clinical applications (PolyActive $^{\mathrm{TM}}$, IsoTis Orthopaedics S.A.) as dermal substitutes [26] and bone fillers $[27,28]$.

\subsection{Materials and Methods}

\subsubsection{Casting of agarose microwell arrays}

Agarose microwell arrays were prepared with a soft-lithography technique. Polydimethylsiloxane (PDMS) negative molds were used to routinely cast the arrays, with 
microwells with a diameter of $200 \mu \mathrm{m}$, in $3 \%$ agarose gel as described earlier [29]. Ultrapure C Agarose (Invitrogen, Carlsbad, CA) was dissolved with a concentration of $3 \% \mathrm{w} / \mathrm{v}$ in sterile phosphate-buffered saline (PBS) solution (Gibco, Carlsbad, CA) by heating. Seven milliliter of dissolved agarose were pipetted into each well of a 6 -well tissue culture plate in which the molds were previously placed (one mold/well) and centrifuged briefly to remove air bubbles. After setting in $4{ }^{\circ} \mathrm{C}$ for 30 minutes, the solidified gels with the microwell arrays were removed from the wells and separated from the mold using a spatula. A cylindrical puncher was used to cut out the microwell arrays to fit a standard 12 wells plate.

\subsubsection{Fabrication of PEOT/PBT scaffolds}

300PEOT55PBT45 (PolyActive ${ }^{\mathrm{TM}} 300 / 55 / 45$, PolyVation, The Netherlands) is a block copolymer with a weight ratio of 55 to 45 for the two components (PEOT and PBT) respectively, and a molecular weight of the starting poly(ethylene glycol) (PEG) segments of 300 Da used in the co-polymerization process. 3D regular grids were fabricated by 3D fiber deposition with a bioscaffolder (SysENG, Germany) with a fiber to fiber distance of $800 \mu \mathrm{m}$, a fiber diameter of approximately $200 \mu \mathrm{m}$ and a layer thickness of $150 \mu \mathrm{m}$. Cylindrical porous scaffolds $(6 \mathrm{~mm}$ in diameter by 4 $\mathrm{mm}$ in height for the semi-confocal Raman study and $4 \mathrm{~mm}$ in diameter by $3 \mathrm{~mm}$ in height for the confocal and the fiber optic Raman study) were punched out of the 3D regular grids. These scaffolds were sterilized in $70 \%$ ethanol 2 times for 30 minutes each, washed in PBS first for 5 minutes and additionally for other 30 minutes two times, and finally incubated in culture medium overnight prior to cell culture.

\subsubsection{Isolation of bovine chondrocytes and cell culture}

Primary bovine chondrocytes were isolated from articular cartilage derived from the femoral-patellar groove of a 10-month-old calf by digestion with $420 \mathrm{U} / \mathrm{mL}$ collagenase type-II (Worthington Biochemical, Lakewood, NJ). The freshly isolated passage 0 (P0) chondrocytes were cultured in chondrocyte medium (CM) consisting of Dulbecco's modified eagle medium (DMEM, Gibco, Carlsbad, CA) containing 10 v/v \% heat-inactivated fetal bovine serum (FBS, South American Origin; Biowhittaker, Lonza, Verviers, Belgium), $100 \mathrm{U} / \mathrm{mL}$ penicillin G (Invitrogen, Carlsbad, CA), $100 \mu \mathrm{g} / \mathrm{mL}$ streptomycin (Invitrogen), $0.1 \mathrm{mM}$ nonessential amino acids (Sigma, St. Louis, MO), $0.4 \mathrm{mM}$ proline (Sigma, St. Louis, MO), and $0.2 \mathrm{mM}$ L-ascorbic-acid2-phosphate (Sigma, St. Louis, MO) at $37{ }^{\circ} \mathrm{C}$ under a humidified atmosphere of $5 \%$ $\mathrm{CO}_{2}$.

After being cultured on tissue culture plastic (T-flask; Nunc; Thermo Fischer Scientific, Roskilde, Denmark), in control samples chondrocytes (P1) were seeded on scaffolds in CM. During the single cells versus aggregates study (confocal Raman study), one half of the chondrocytes (P1) were used for scaffolds, the other half were used for creation of chondrocyte aggregates using agarose microwell arrays in CM (2865 microwells and $1 \times 10^{6}$ cells/agarose microwell array). Chondrocytes seeded in these microwells spontaneously formed microaggregates ( $\sim 350$ cells/microaggregate) at the bottom of the microwells after 12 hours. Subsequently, at 1 day of culture, the 
chondrocyte microaggregates were flushed out with CM from the agarose microwell arrays, collected and seeded on scaffolds.

\subsubsection{Cell seeding of PEOT/PBT scaffolds}

Each scaffold was placed aseptically into a well of a non-tissue culture treated 24 wells (in the semi-confocal Raman study) or 48 wells plate (in the confocal and fiber optic Raman study) (both Nunc, Thermo Fisher Scientific, Roskilde, Denmark).

In the semi-confocal Raman study, human fibronectin $(300 \mu \mathrm{g} / \mathrm{mL}$, BD Biosciences), which is known to support cell adhesion [30], was applied to the chondrocyte suspension before seeding onto the scaffolds The cell-fibronectin suspension, $3 \times 10^{6}$ cells in a final volume of $50 \mu \mathrm{L}$ for each scaffold, was pipetted onto scaffolds and left to completely adsorb into the porous structure. Samples were left in an incubator at $37{ }^{\circ} \mathrm{C}$ under a humidified atmosphere of $5 \% \mathrm{CO}_{2}$ for 45 minutes. Subsequently, 2 $\mathrm{mL}$ of culture medium was carefully added drop wise. After 7 and 21 days of culture the samples were studied using Raman microspectroscopy. Chondrocytes of C-28/I2 human immortalized chondrocyte cell line were also seeded on PEOT/PBT scaffolds. C-28/I2 cells were used as a negative control for matrix formation, since they were previously described showing mainly proliferation and low gene expression involved in extracellular matrix synthesis and turnover [31]. C-28/I2 cell seeded samples were cultured in $\mathrm{CM}$ under a humidified atmosphere of $5 \% \mathrm{CO}_{2}$ at $37{ }^{\circ} \mathrm{C}$ and analyzed by Raman microspectroscopy after 21 days of culture period.

In the confocal Raman study (single cells versus microaggregates study) and fiber optic Raman study, before transferring the PEOT/PBT scaffolds into 48 wells plates, a layer of $3 \%$ agarose gel was deposited onto the bottom of each individual well. A circular hole with a diameter slightly bigger than the scaffold was punched out from the middle of the gel in each well and the scaffolds were placed into these holes (one scaffold per well/hole). These holes serve as barriers to prevent cell suspension from flowing out of the scaffold, providing efficient cell seeding. For fiber optic Raman measurements, only single cell-seeded samples were used. The single chondrocyte or microaggregate suspension (both without fibronectin) consisting of 500,000 cells, or 500,000 cells in microaggregates in a final volume of $30 \mu \mathrm{L}$ per scaffold, were seeded onto scaffolds drop wise. Subsequently, samples were left undisturbed for 45 minutes and then $1 \mathrm{~mL}$ of culture medium was carefully added drop wise. Cell seeded samples were cultured in chondrogenic differentiation medium consisting of DMEM supplemented with $100 \mathrm{U} / \mathrm{mL}$ penicillin $\mathrm{G}, 100 \mu \mathrm{g} / \mathrm{mL}$ streptomycin, $40 \mu \mathrm{g} / \mathrm{mL}$ proline, 0.2 mM L-ascorbic-acid-2-phosphate, $50 \mathrm{mg} / \mathrm{mL}$ insulin-transferrin-selenite (ITS) Premix (Bexton Dickinson), $100 \mu \mathrm{g} / \mathrm{mL}$ sodium pyruvate (Sigma), $10 \mathrm{ng} / \mathrm{mL}$ transforming growth factor- $\beta 3$ (TGF- $\beta 3$, Invitrogen) and $0.1 \mu \mathrm{M}$ dexamethasone (Sigma), at 37 ${ }^{\circ} \mathrm{C}$ under a humidified atmosphere of $5 \% \mathrm{CO}_{2}$. After 7,14 and 21 days of culture analysis of ECM formation was performed by Raman microspectroscopy, total DNA quantification, GAG and hydroxyproline detection assay, SEM and histology. 


\subsubsection{Semi-Confocal Raman Microspectroscopy}

Samples for the semi-confocal Raman study were monitored by using a Nikon E600 epifluorescence microscope (Nikon, Inc., Melville, New York) modified for near-infrared (NIR) Raman spectroscope in house which was previously described [32] Briefly, a 785nm Kaiser Invictus laser was line-focused (Kaiser Optical Systems, Inc., Ann Arbor, Michigan) onto the samples using a $20 \times / 0.75$ NA S Fluor objective. Raman-scattered light was collected through the same $20 \times / 0.75$ NA S Fluor objective and dispersed through a spectrograph (HoloSpec $f / 1.8$, Kaiser Optical Systems, Inc.). Prior to Raman measurements, samples were transferred onto fused silica slides. Raman signal was collected for 180 seconds on a charge-coupled device (CCD) detector optimized for NIR wavelengths (DU401-BR-DD, Andor Technologies, Belfast, Northern Ireland). Raman transects consisted of 126 Raman spectra arranged at equidistant points along a line through the specimen. Compared to confocal Raman systems (point-mapping mode), the confocality is reduced along the slit. Three transects were collected at three various locations (in three pores) across the surface of each scaffold-sample and time point (one sample per time point). A total of $378(3 \times 126)$ Raman spectra were collected from each scaffold and time point in this study. Bright field micrographs were collected with a stereomicroscope (Nikon, SMZ800) and with a Plan Apo $1 \times / 0.1$ NA objective from each scaffold at all time points.

\subsubsection{Confocal Raman Microspectroscopy}

In the confocal Raman study, measurements were performed using a home-built confocal Raman spectrometer as described earlier [12, 33, 34] on the tissue engineered constructs. Briefly, a Krypton ion laser (Coherent, Innova 90K, Santa Clara, CA) with an emission wavelength of $647.1 \mathrm{~nm}$ was used as the excitation source. A $40 \times / 0.75$ NA Olympus UIS2 objective (UPlanFLN, Olympus, Hamburg, Europe) was used to illuminate the sample as well as to collect the Raman-scattered photons in epidetection mode. The scattered light was filtered by a razor-edge filter (Semrock, Rochester, NY, USA) to suppress reflected laser light and Rayleigh-scattered light, and focused onto a pinhole of $15 \mathrm{~m}$ diameter at the entrance of an imaging spectrograph (HR460; Jobin-Yvon, Paris, France), which contained a blazed holographic grating with 600 grooves $/ \mathrm{mm}$. The spectrograph dispersed the Raman-scattered photons on an air-cooled electron-multiplying CCD detector (Newton DU-970N, Andor Technology, Belfast, Northern Ireland). The system provided a spectral resolution of 1.85 to $2.85 \mathrm{~cm}^{-1} /$ pixel over the wavenumber range from -20 to $3670 \mathrm{~cm}^{-1}$. Raman images were acquired from the samples by recording a full spectrum from each position of the laser beam guided by the displacement of the scanning mirror in the area of interest on the samples. Each Raman scan resulted in 1024 spectra. These measurements were performed in an area of $30 \times 30 \mu \mathrm{m}$ with a spectral resolution of $310 \mathrm{~nm}$ per scan, an accumulation time of $1 \mathrm{~s} / \mathrm{step}$ and an excitation power of $35 \mathrm{~mW}$. Three Raman images were collected from three pores of each sample and triplicates of samples were measured each time point. The samples were scanned by using a scanning mirror system (SM, MG325D and G120D, General Scanning, Bedford, USA). Toluene, a Raman calibration standard, which has accurately known peak frequencies (521, 785, 1004, 1624, 2921 and $\left.3054 \mathrm{~cm}^{-1}\right)$, was used for wavenumber calibration of 


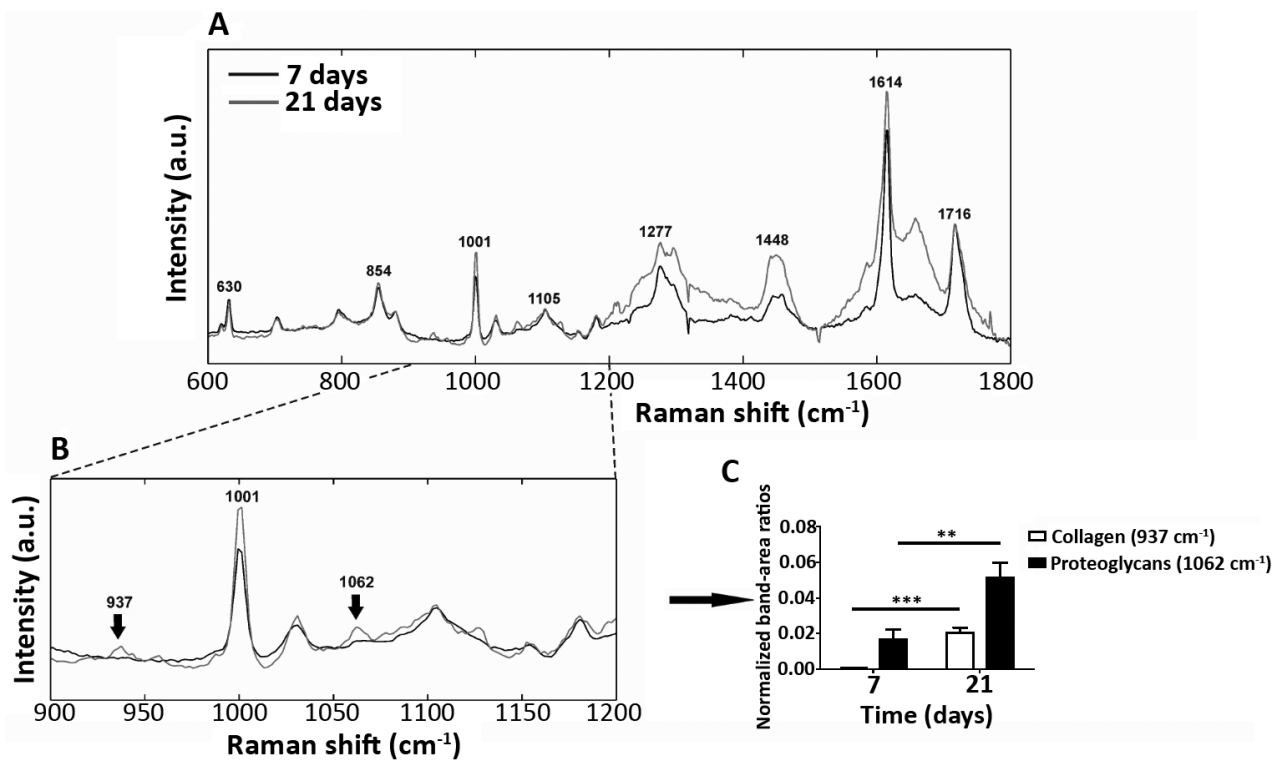

Figure 7.1: Baseline corrected mean Raman transects from samples of PEOT/PBT scaffolds, seeded with bovine chondrocytes, acquired after 7 and 21 days of culture period and collected by the semi-confocal Raman setup in the region A: from $600 \mathrm{~cm}^{-1}$ to $1800 \mathrm{~cm}^{-1}$ B: from $900 \mathrm{~cm}^{-1}$ to $1300 \mathrm{~cm}^{-1}$. Increased intensities of the Raman bands at $937 \mathrm{~cm}^{-1}$ (collagen) and $1062 \mathrm{~cm}^{-1}$ (proteoglycans) were clearly visible from day 7 to day 21 of the culture period. C: Semi-quantitative univariate data analysis showed normalized integrated band-area ratios of the collagen (white bar) and proteoglycan (black bar) bands after 7 and 21 days of culture period. The normalized band-area ratios were obtained from the ratio of the collagen or proteoglycan band over the band of phenylalanine $\left(1001 \mathrm{~cm}^{-1}\right)$. All bands were integrated after baseline subtraction. The normalized band-area ratio for both collagen and proteoglycan content were significantly increased from day 7 to day 21 of culture period (collagen: $\mathrm{p}=0.0003$; sGAG: $\mathrm{p}=0.0065$ ).

the spectra. Prior to Raman measurements, samples were washed with PBS, fixed in $10 \%$ formalin for 10 minutes, washed extensively with PBS afterwards and placed onto UV grade calcium fluoride slides (Crystran Ltd., UK).

\subsubsection{Raman data analysis}

Spectra obtained from the semi-confocal Raman study were corrected for curvature, dark current, and variations in the CCD quantum efficiency. A mean spectrum was calculated and baseline-corrected from each transect after correction for the fused silica background.

Preprocessing of spectra obtained from the confocal Raman study was performed as described previously [34-36]. The spectra were preprocessed by: (1) removing cosmic ray events; (2) subtracting the camera offset noise (dark current); and (3) calibrating the wave number axis. The well-known band-positions were used to relate 


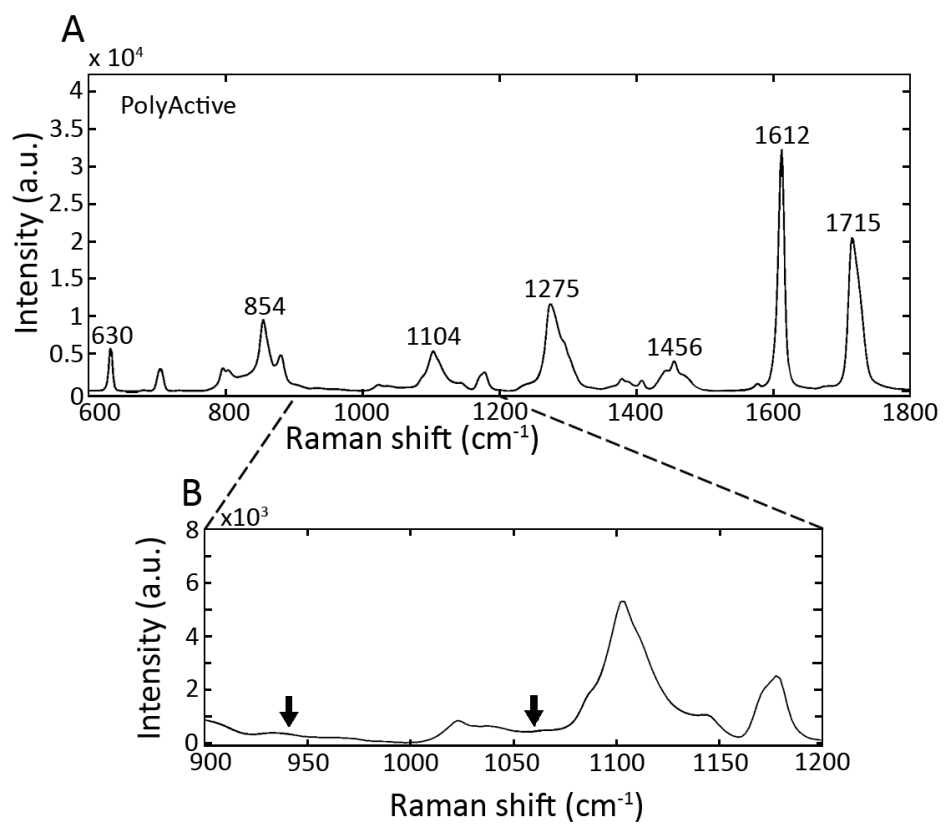

Figure 7.2: Mean Raman transects from a PEOT/PBT scaffold without cells in the region A: from $600 \mathrm{~cm}^{-1}$ to $1800 \mathrm{~cm}^{-1}$ and B: from $900 \mathrm{~cm}^{-1}$ to $1300 \mathrm{~cm}^{-1}$. The Raman spectrum shows Raman bands in the same region as the Raman spectra of the cell-seeded scaffolds displayed in Figure 7.1. However PEOT/PBT specific bands can be easily recognized and do not interfere with ECM specific bands at 937 and $1062 \mathrm{~cm}^{-1}$.

wavenumbers to pixels. The frequency-dependent optical detection efficiency of the setup was corrected using a tungsten halogen light source (Avalight-HAL; Avantes BV, Eerbeek, The Netherlands) with a known emission spectrum. The detectorinduced etaloning effect was compensated by this procedure. After data correction, the spectra of the Raman scans on respective measurement days were averaged to generate mean spectra for each sample.

Both in the semi-confocal and confocal Raman study semi-quantitative univariate data analysis was performed by selecting specific vibrational bands of collagen or/and sGAGs in the averaged spectra from each time point, and integrating each band after local baseline subtraction. Subsequently, normalized band-area ratios were obtained from the collagen and proteoglycan bands separately over the integrated band of the phenylalanine ring breathing mode at $1001 \mathrm{~cm}^{-1}$. The calculations were made using normalized band-area ratios, not absolute values, so the system is rather a semiquantitative than a quantitative monitoring of the collagen and sGAG formation [12]. All data manipulations were performed using routines written in MATLAB 7.4 (The Math Works Inc., Natick, MA). 


\subsubsection{Fiber-optic Raman spectroscopy and data analysis}

Fiber-optic Raman measurement was carried out using a custom designed fiber optic Raman probe. Details of the Raman probe design have been previously described $[15,37]$. Briefly, the fiber optic Raman probe consisted of 50-collection fibers that were arranged into 10 branches. The fibers employed in the probe design are silica fibers with core diameter of $100 \mu \mathrm{m}$. Each branch housed 5-fibers and terminated in a stainless steel ferrule with an outer diameter of $1.25 \mathrm{~mm}$. The Raman probe was used with a custom designed aluminum probe holder to facilitate contact of each fiber with the scaffold. The Raman collection probes were bundled at the distal end into a linear array for coupling to the Raman spectrograph (RamanRxn1, Kaiser Optical Systems Inc.). Laser illumination was achieved using a $300 \mu \mathrm{m}$ core optical fiber, that terminated in a stainless steel ferrule $(\mathrm{OD}=400 \mu \mathrm{m})$ and coupled to an $830 \mathrm{~nm}$ laser source. Raman data were acquired with the fiber optic Raman probe and processed with MATLAB - including silica subtraction - to generate ten Raman spectra for all collection probes. Data processing includes dark subtraction, removal of spikes due to cosmic rays and correction for grating induced curvature. Silica contribution from the optical fibers was subtracted by derivative subtraction of silica background spectra that was acquired by reflecting the excitation laser from a frosted aluminum surface into the optical fibers. Further processing included baseline subtraction using a $5^{\text {th }}$ order polynomial [38]. The ten Raman spectra were averaged to generate mean spectra for each sample (each single cell-seeded scaffold).

\subsubsection{GAG detection assay}

Following 7 and 14 days of culture, samples from the confocal Raman study were washed with PBS and frozen at $80{ }^{\circ} \mathrm{C}$. After thawing, the constructs were digested for 16 hours at $56{ }^{\circ} \mathrm{C}$ with $1 \mathrm{mg} / \mathrm{mL}$ proteinase $\mathrm{K}$ (Sigma-Aldrich) in Tris/EDTA buffer (pH 7.6). This solution contained $185 \mu \mathrm{g} / \mathrm{mL}$ iodoacetamine and $10 \mu \mathrm{g} / \mathrm{mL}$ Pepstatin A (both Sigma Aldrich). Quantification of total DNA was done using the CyQuant DNA assay (MolecularProbes) and a spectrophotometer (excitation 480 $\mathrm{nm}$, emission $520 \mathrm{~nm}$, Victor3, Perkin Elmer). The amount of GAG was determined spectrophotometrically after reaction with dimethylmethylene blue dye (DMMB, SigmaAldrich) in a $10 \mathrm{mM}$ hydrochloric acid solution containing $3.04 \mathrm{~g} / \mathrm{L}$ of glycine and $2.37 \mathrm{~g} / \mathrm{L}$ of $\mathrm{NaCl}(\mathrm{pH} 3)$. A micro plate reader (Multiskan GO, Thermo Fisher) was used to determine the absorbance at $520 \mathrm{~nm}$. The amount of GAG was calculated using a standard of chondroitin sulfate (SigmaAldrich).

\subsubsection{Hydroxyproline assay}

Hydroxyproline assay was carried out on the same proteinase $\mathrm{K}$ digested samples as for the GAG assay and DNA quantification. From the digested sample $15 \mu \mathrm{L}$ was transferred to a teflon capped glass bottle, $15 \mu \mathrm{L}$ of concentrated hydrochloric acid $\left(\mathrm{HCl}, 12 \mathrm{M}\right.$ ) was added and samples were hydrolyzed at $120{ }^{\circ} \mathrm{C}$ for 3 hours. The complete supernatant was transferred to a 96 well plate and left to evaporate at 60 ${ }^{\circ} \mathrm{C}$. Subsequently, $100 \mu \mathrm{L}$ of chloramine $\mathrm{T} /$ Oxidation buffer mix was added to each well and incubated at room temperature for 5 minutes. Finally $100 \mu \mathrm{L}$ of DMAB 
Reagent was added to each including the hydroxyproline standard and incubated for 90 minutes at $60{ }^{\circ} \mathrm{C}$. A micro plate reader (Multiskan GO, Thermo Fisher) was used to determine the absorbance at $560 \mathrm{~nm}$.

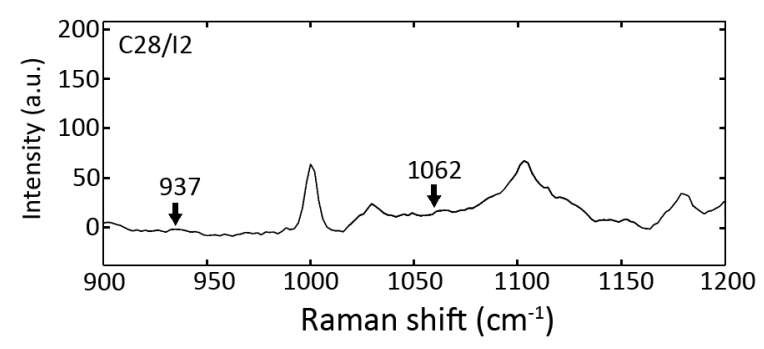

Figure 7.3: Mean Raman transect from PEOT/PBT scaffold seeded with human C28/I2 chondrocytes (negative control for extracellular matrix formation) in the region from 900 $\mathrm{cm}^{-1}$ to $1200 \mathrm{~cm}^{-1}$ at day 21 of culture period. Mean Raman transect does not show bands at $937 \mathrm{~cm}^{-1}$ (collagen) and at $1062 \mathrm{~cm}^{-1}$ (proteoglycans).

\subsubsection{Histology}

In the confocal Raman study, after Raman measurements, samples were embedded in glycol methacrylate (GMA) for histological analysis, sectioned at $10 \mu \mathrm{m}$ intervals, and stained with Safranin-O (Sigma) for visualization of sulfated glycosaminoglycans (sGAGs), and hematoxylin and eosin (H\&E, Sigma) for visualization of the nuclei and cytoplasm.

\subsubsection{Scanning Electron Microscopy (SEM)}

Cell morphology and attachment was characterized by SEM analysis with a Philips XL 30 ESEM-FEG. Samples (from the confocal Raman study) were fixed for 30 minutes in $10 \%$ formalin. Subsequently the samples were dehydrated in sequential ethanol series and critical point dried from liquid carbon dioxide using a Balzers CPD 030 Critical Point Dryer. The constructs were gold sputter coated (Cressington) prior to SEM analysis.

\subsubsection{Statistical analysis}

The results are presented as mean \pm standard deviation (SD). Experimental data were analyzed for statistical significance using a student t-test. Statistical significance was set to p-value $<0.05\left(^{*}\right)$.

\subsection{Results and Discussion}

The aim of this study is to investigate the use of conventional (semi-confocal and confocal) and fiber-optic Raman microspectroscopy for monitoring ECM formation dur- 

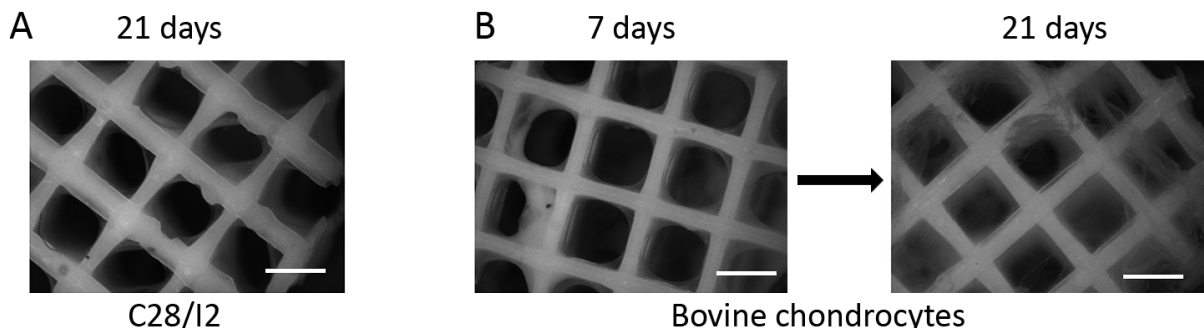

Figure 7.4: Bright field micrographs of A: PEOT/PBT scaffold seeded with human C28/I2 chondrocytes at day 21 of culture period and B: PEOT/PBT scaffold seeded with bovine chondrocytes at day 7 and 21 of culture period. Abundant ECM formation was observed in scaffolds seeded with bovine chondrocytes. The image was made with a $10 \times$ objective and scale bars are equal to $1000 \mu \mathrm{m}$

ing cell culture in, 3D fiber deposited porous PEOT/PBT scaffolds. Moreover, chondrocytes have been seeded as single cells and as microaggregates onto the PEOT/PBT scaffolds, to investigate if there are differences in ECM formation between single celland cell aggregate-seeded scaffolds. The rationale of using microaggregates instead of single chondrocytes was to initiate increased ECM formation. It is known that threedimensional aggregation is an essential step in chondrogenesis and sustains matrix production of chondrocytes [39-41].

In the semi-confocal Raman study, Raman transects from PEOT/PBT scaffolds seeded with bovine chondrocytes were acquired after 7 and 21 days of culture period using a conventional Raman setup. Mean Raman transects of these samples showed increased intensities of the bands at $937 \mathrm{~cm}^{-1}$ and $1062 \mathrm{~cm}^{-1}$ from day 7 to day 21 of the culture period (Figure 7.1A and B - truncated). These bands correspond to collagen (proline, hydroxyproline, C-C vibrations of collagen backbone) [42] and chondroitin sulfate and proteoglycans (including aggrecan) [10, 43, 44] respectively, which are essential components of the ECM in cartilage.

It was previously described that the band of collagen found at $937 \mathrm{~cm}^{-1}$ can be used as a Raman marker for collagen-containing extracellular matrix formation over time in chondrocyte pellet cultures [12]. Furthermore, chondrocyte behavior on bioactive scaffolds has already been monitored by using Raman spectra from the extracellular matrix deposited onto such scaffolds and by assessing Raman bands indicative for collagen and amide $I$ in the spectral region between $1200 \mathrm{~cm}^{-1}$ and $1800 \mathrm{~cm}^{-1}[13]$. In order to quantify changes in intensities of bands at $937 \mathrm{~cm}^{-1}$ and $1062 \mathrm{~cm}^{-1}$, we used semi-quantitative univariate data analysis.

The results of the univariate data analysis are shown in Figure $7.1 \mathrm{C}$ with the normalized band area ratios for the band signifying collagen and proteoglycans. Subsequently, band-area ratios were obtained from collagen and proteoglycan bands separately over the integrated band of the phenylalanine ring breathing mode at 1001 $\mathrm{cm}^{-1}[45]$. Phenylalanine was found to be the best-resolved band and is not sensitive to local chemical environments [32]. The normalized band-area ratio for both collagen and proteoglycan content increased from day 7 to day 21 of culture period.

Mean Raman transects were also obtained from PEOT/PBT scaffolds without 
cells (Figure 7.2A and B - truncated) as reference spectra. Comparing these spectra with the mean Raman spectra of cell-seeded scaffolds on Figure 7.1A and B, Raman contributions of PEOT/PBT polymer can be distinguished at $630 \mathrm{~cm}^{-1}, 854 \mathrm{~cm}^{-1}$ and between $1100 \mathrm{~cm}^{-1}$ and $1800 \mathrm{~cm}^{-1}$ in Raman spectra from cell-seeded scaffolds. The area of measurement on ECM overlaps in some cases with part of the polymer scaffold during Raman imaging, leading to Raman contributions from the polymer in the obtained spectra. Yet, PEOT/PBT specific bands can be easily recognized and do not interfere with ECM specific bands at 937 and $1062 \mathrm{~cm}^{-1}$.

Raman transects from PEOT/PBT scaffolds seeded with the C-28/I2 human immortalized chondrocyte cell line, used as negative control for ECM formation, were collected after 21 days of culture period similar to bovine chondrocyte-seeded samples. The average of the Raman transects of these samples did not show bands at $937 \mathrm{~cm}^{-1}$ (collagen) and at $1062 \mathrm{~cm}^{-1}$ (proteoglycans), even after 21 days of culture (Figure 7.3). Furthermore, bright field microscopy of these samples showed that no ECM was present (Figure 7.4A) which confirmed the analysis done based on Raman spectra. In contrast, the bright field micrographs of bovine chondrocyte-seeded samples (Figure 7.4B) showed collagen like fiber formation at day 7 of the culture period indicative of ECM production. Moreover, the amount of ECM further increased in time completely covering the scaffolds at day 21 (Figure 7.4B).

In the confocal Raman study presented here the seeding of single chondrocytes was compared to seeding of chondrocyte microaggregates on three-dimensional fiber deposited PEOT/PBT scaffolds. In a previous study, similar 3D polymer scaffolds were seeded with bovine articular chondrocytes in spinner flasks, so that stirred cell culture promoted the formation of cell aggregates as were used in this study [46]. In that previous study, cell aggregation enhanced the kinetics of cell attachment without compromising the uniformity of cell distribution on the scaffolds [46]. In our confocal Raman study, chondrogenic differentiation medium was used, to stimulate proteoglycan synthesis from chondrocytes in 3D cell culture in the same way as was done by Mauck and co-workers [47]. Mean Raman spectra from single chondrocyte- and chondrocyte microaggregate-seeded scaffolds (Figure 7.5) showed bands corresponding to phenylalanine (C-C aromatic ring) at $1001 \mathrm{~cm}^{-1}$ [45], lipids/proteins ( $\mathrm{CH} 2$ bending mode) at $1448 \mathrm{~cm}^{-1}$ [48] and amide I at $1657 \mathrm{~cm}^{-1}$ [49]. Additionally, Raman bands at $937 \mathrm{~cm}^{-1}$ (collagen) and at $1062 \mathrm{~cm}^{-1}$ (proteoglycans) were also detected indicating ECM deposition.

Although normalized band-area ratios for proteoglycan content did not change over time, collagen synthesis was found to be different in single chondrocyte-seeded scaffolds when compared to microaggregate-seeded samples (Figure 7.5B and C). The normalized band-area ratios for total collagen content of single cell-seeded samples gradually decreased during a 21-day culture period (Figure 7.5B), whereas the total collagen content of the microaggregate-seeded samples had significantly increased (Figure 7.5C) during this period.

Several studies with chondrocytes have shown correlation between the aggregation of chondrocytes in multiple layers and enhanced cartilaginous tissue formation [41, 50-52]. Our Raman results in this study also indicate that the use of chondrocyte microaggregates, instead of single chondrocytes, for cell seeding of scaffolds could be used to enhance ECM formation and therefore could potentially lead to more 
A
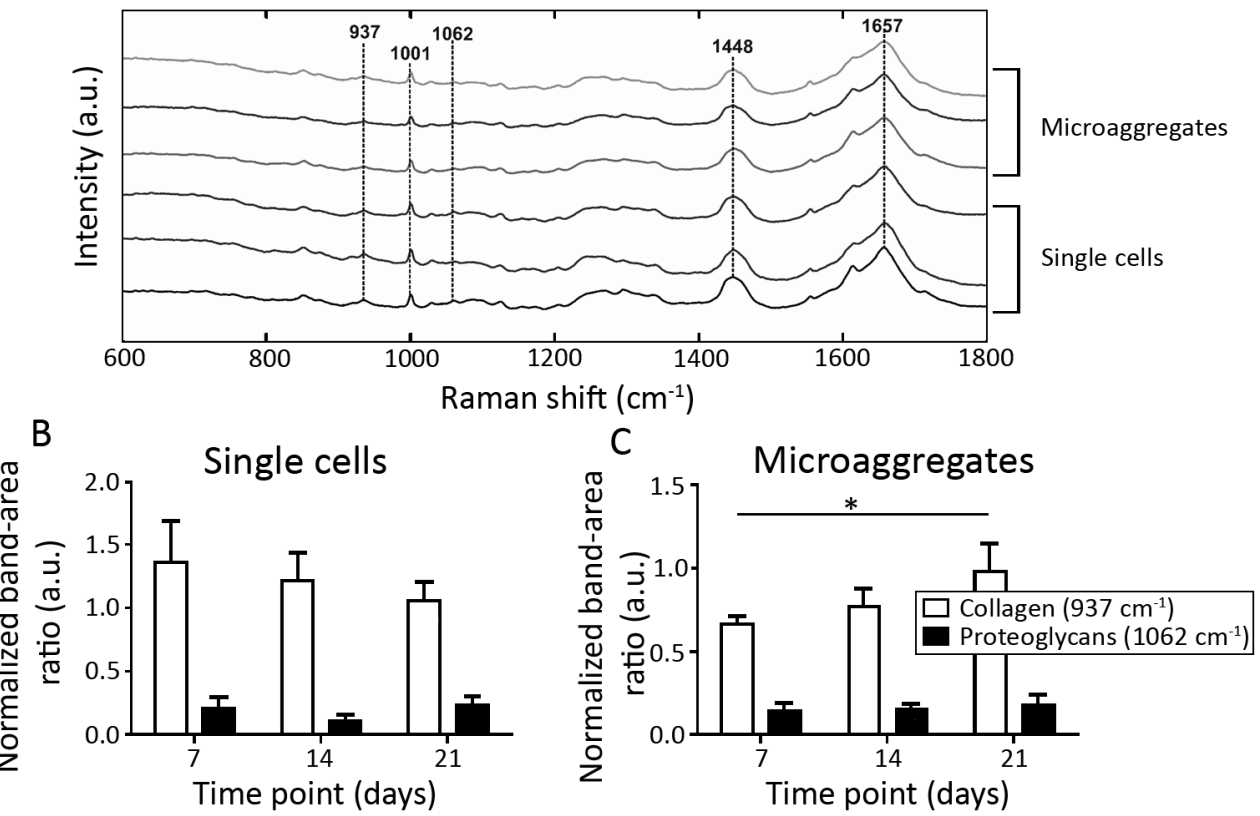

Figure 7.5: Mean Raman spectra and corresponding normalized band-area ratios of PEOT/PBT scaffolds seeded with bovine single chondrocytes or chondrocyte microaggregates. A: Mean Raman spectra acquired after 7, 14 and 21 days of culture period and collected by the confocal Raman setup in the region from $600 \mathrm{~cm}^{-1}$ to $1800 \mathrm{~cm}^{-1}$. The spectra were vertically displaced for clarity: (a) 7 days, (b) 14 days, (c) 21 days cultured scaffolds seeded with single chondrocytes, and (d) 7 days, (e) 14 days and (f) 21 days cultured scaffolds seeded with chondrocyte microaggregates. B, C: Semi-quantitative univariate data analysis showed normalized integrated band-area ratios of collagen (white bar) and proteoglycans (black bar) bands for the Raman spectra of single cell-seeded and microaggregate-seeded scaffolds at day 7,14 and 21 of culture period. The normalized band-area ratio acquired from the ratio of the collagen or proteoglycan band to the band of phenylalanine $\left(1001 \mathrm{~cm}^{-1}\right)$. All bands were integrated after baseline subtraction. Although normalized band-area ratios for proteoglycan content did not change over time, but collagen synthesis was found to be different in single chondrocyte-seeded scaffolds when compared to microaggregateseeded samples. While normalized band-area ratios for collagen content of single cell-seeded samples gradually decreased during the 21 day culture period, the collagen content of the microaggregate-seeded samples showed a significantly increase during this period $(p=0.0353)$.

functional cartilage tissue engineered constructs.

ECM formation in the single chondrocyte-seeded scaffolds was also evaluated using fiber optic Raman spectroscopy. The experimental fiber optic Raman setup for measurements can be seen in Figure 7.6A. Average Raman spectra from single chondrocyte-seeded scaffolds cultured for 14 days and 21 days mainly showed Raman contributions from the optical fibers (i.e. residual silica Raman spectra) even after silica background subtraction. However, Raman spectra of cell-seeded scaffolds showed 


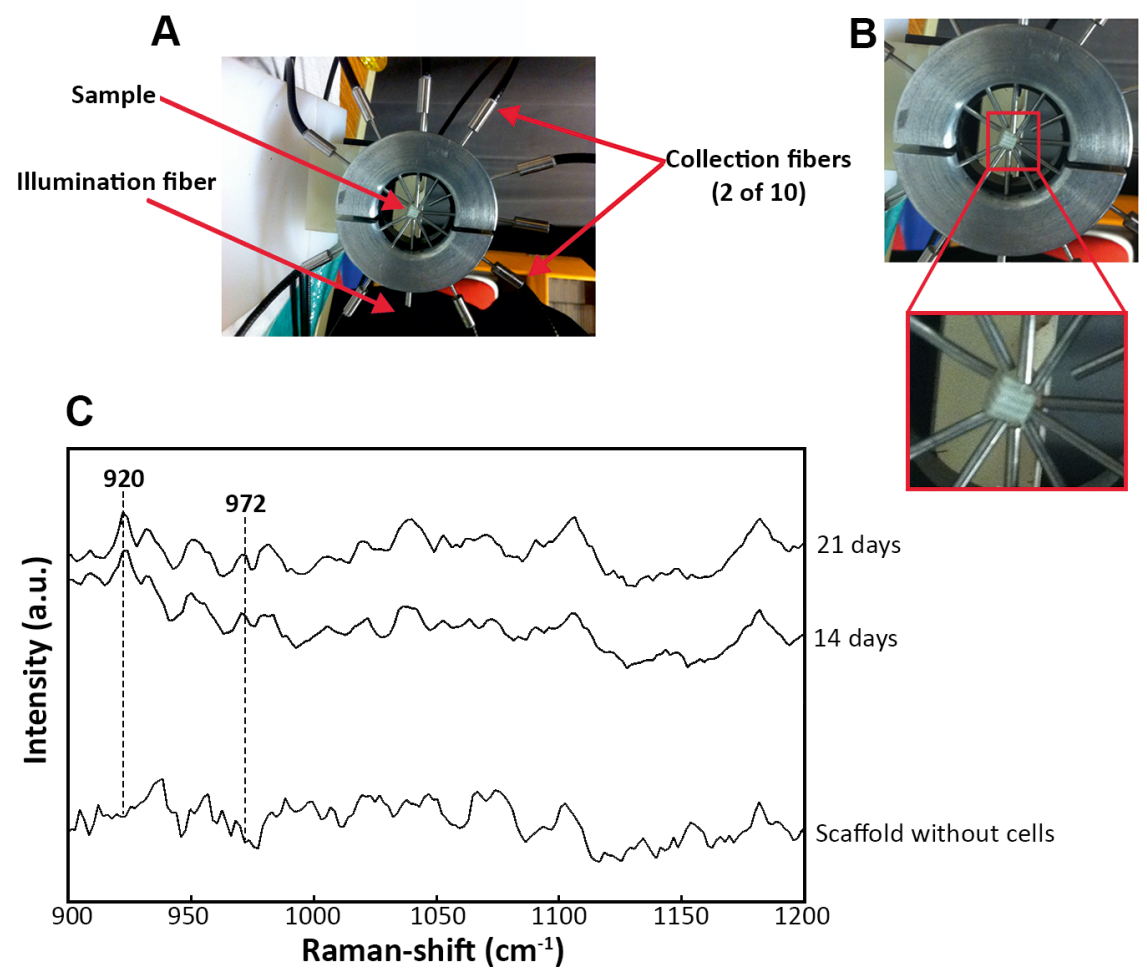

Figure 7.6: Setup of fiber-optic Raman probe for measurement on single chondrocyteseeded scaffolds. A-B: The illumination and collection fibers were spread around the scaffold using a custom design aluminium probe holder to facilitate contact of each fiber with the scaffold. C: Mean Raman spectra from scaffolds seeded with single bovine chondrocytes at day 14 and 21 of culture period and from scaffolds without cells showing the spectral region from $900 \mathrm{~cm}^{-1}$ to $1200 \mathrm{~cm}^{-1}$. Although, the Raman spectra collected with the fiber-optic setup shows inherent background signal generated by silica within the optical fiber, the bands at $920 \mathrm{~cm}^{-1}$ and $972 \mathrm{~cm}^{-1}$ (attributes of ECM) are still recoverable.

Raman bands at 920 and $972 \mathrm{~cm}^{-1}$ corresponding to components of collagen, such as aminoacid proline, which were not found in the spectra of the scaffold without cells. We show in Figure 7.2 that PEOT/PBT spectra do not show Raman bands in the spectral region between 900 and $1100 \mathrm{~cm}^{-1}$. Therefore, bands arising in this region in spectra of bare scaffolds, as can be seen in Figure 7.6B, originate from Raman scattering generated from the silica within the optical fibers, which were not completely removed by derivative silica subtraction algorithm performed with codes written in MATLAB. A suitable algorithm in MATLAB for more accurate silica background subtraction and/or further data processing using multivariate statistical technique such as Band target entropy minimization (BTEM) greatly reduces background bands and maximizes the Raman bands specific for ECM.

Additionally, we investigated ECM deposition in the single cell- and 
A

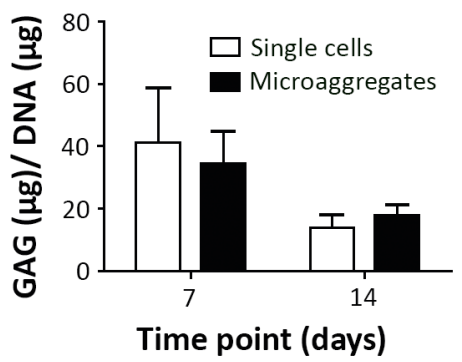

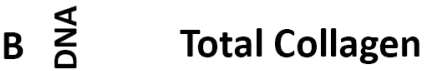

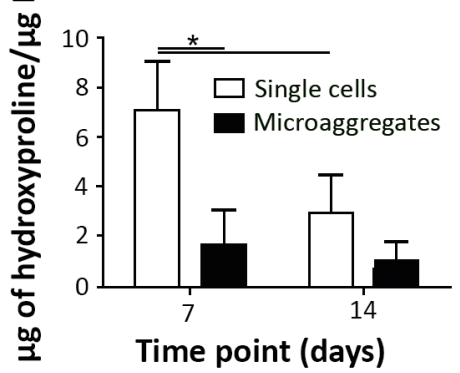

C $H \& E$

Safranin-O
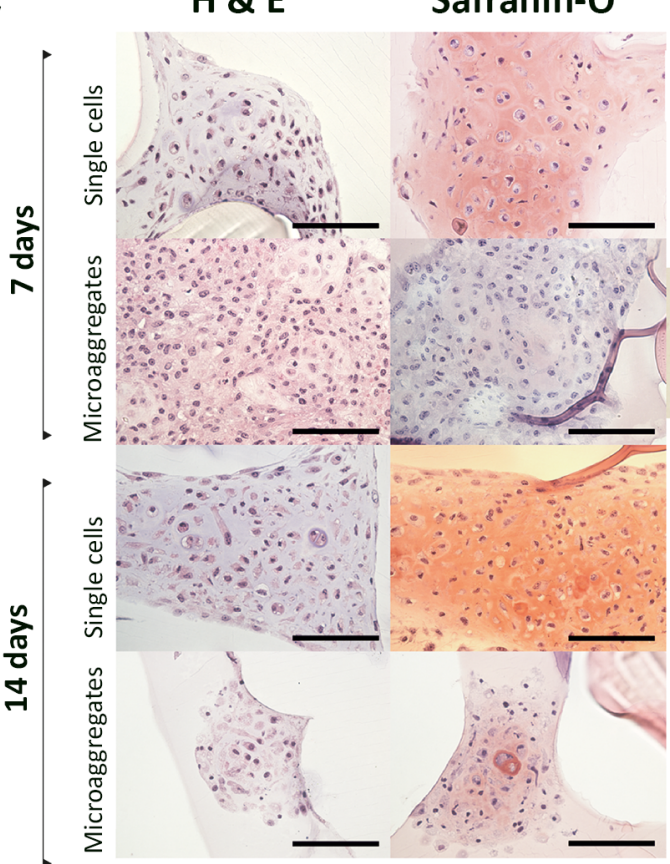

Figure 7.7: Matrix production. A: Results of GAG-assay and B: hydroxyproline assay, a measure for total collagen, both normalized to DNA content of single chondrocyte- or microaggregate-seeded PEOT/PBT scaffolds at day 7 and 14 of culture period. GAG production was successfully detected in all samples, although major significant differences were not observed. Collagen production decreased significantly for single cells when comparing day 7 with day $14(\mathrm{p}=0.042$. Microaggregates show significantly less collagen production than single cells $(\mathrm{p}=0.016)$ after 7 days of culture. C: Result of Safranin O and H\&E staining visualizing sGAG production and nuclei \& cytoplasm respectively in single chondrocytesand microaggregate-seeded scaffold at day 7 and 14 of culture period. Scale bar equals to $100 \mu \mathrm{m}$. 
microaggregate-seeded samples by more conventional methods. GAG formation was successfully detected by biochemical analysis (GAG-assay), both in the single cellseeded and microaggregate-seeded samples at day 7 and 14 of the culture period. However, significant differences were not observed (Figure 7.7A). The hydroxyproline analysis indicated that cells produce significantly more collagen-like matrix per cell when seeded on the scaffolds as single cells compared to microaggregates (Figure 7.7B). Furthermore, higher collagen production per cell was found after 7 days compared to 14 days for single cells. In contrast, the absolute amount of total collagen was comparable for both timepoints in both conditions. The cell number, determined by DNA assay, showed an increase in single cell seeded samples, whereas the DNA content for microaggregates remained stable during culture. This could explain the decrease in time for total collagen produced by single cell-seeded samples.

Moreover, sGAG formation was also successfully shown by Safranin-O staining, and the nuclei and cytoplasm were visualized by H\&E staining both in the single cellseeded and microaggregate-seeded samples at day 7 and 14 of culture period (Figure 7.7C). The results of the Safranin-O indicated milder level of sGAG production in the microaggregate-seeded samples compared to the single cell-seeded ones, which can be explained by the fact that, especially after 14 days, the number of cells in the histological section is lower for microaggregate-seeded samples. This subtle difference in sGAG production was also observed by the GAG assay, although it was not statistically significant.

Furthermore, both the single cell-seeded (Figure 7.8A) and microaggregate-seeded samples (Figure 7.8B) matrix-like structure formation could be observed by electron microscopy. Chondrocyte microaggregates adhering to the scaffold surface could be seen in the SEM micrographs of the microaggregate-seeded samples at day 7 of culture period. After 21 days of culture, the majority of microaggregates had a flattened appearance and collagen like fibrous structures were observed in the vicinity of cells suggesting active ECM formation ultimately covering the surface of the scaffold used.

\subsection{Conclusion}

In this study, the use of conventional (semi-confocal and confocal) Raman microspectroscopy and fiber-optic Raman spectroscopy has been demonstrated for studying the formation of cartilage ECM in 3D fiber deposited PEOT/PBT scaffolds. The three different Raman microscope setups used in this study were all found to be feasible tools to monitor tissue formation inside tissue engineered porous 3D scaffolds. We studied ECM production of primary bovine chondrocytes seeded into 3D fiber deposited PEOT PBT block copolymer constructs during 3 weeks of culture by Raman and conventional bio- and histochemistry. The Raman bands at 937 and $1062 \mathrm{~cm}^{-1}$ corresponding to collagen and proteoglycans respectively was shown to be indicative for ECM production in the Raman spectra as analyzed by fiber optic Raman and confocal Raman measurements inside the pores of the 3D tissue engineered construct. Normalized band-area ratios for proteoglycan content did not show clear differences over time when comparing single chondrocytes with microaggregates seeded into samples. However, we observed that collagen synthesis was different in single chondrocyte-seeded scaffolds when compared to microaggregate-seeded sam- 


\section{A Single chondrocyte-seeded scaffold}
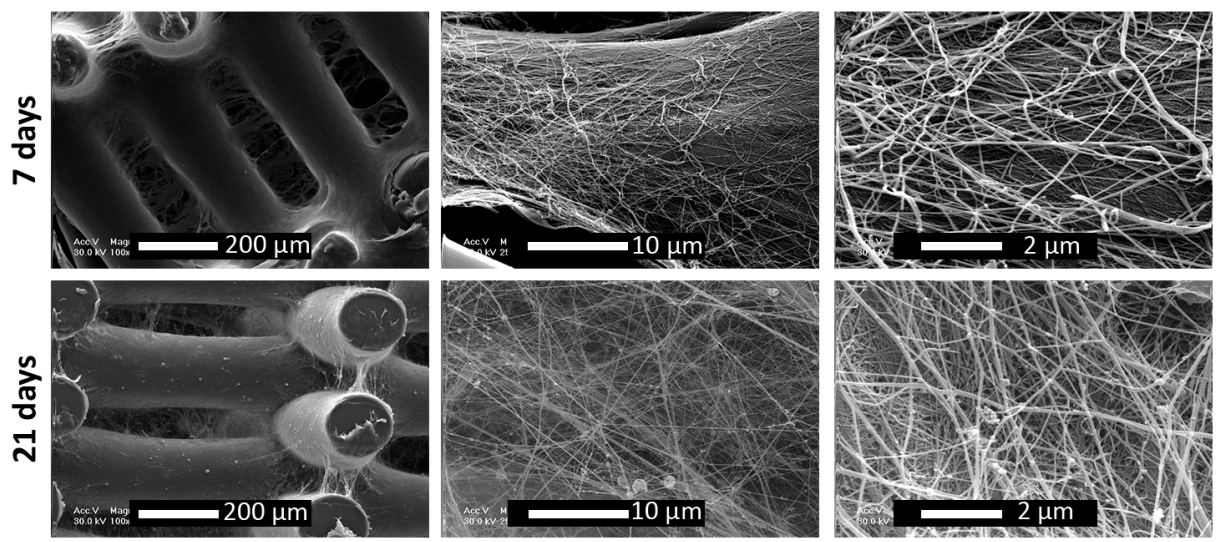

\section{B Microaggregate-seeded scaffold}
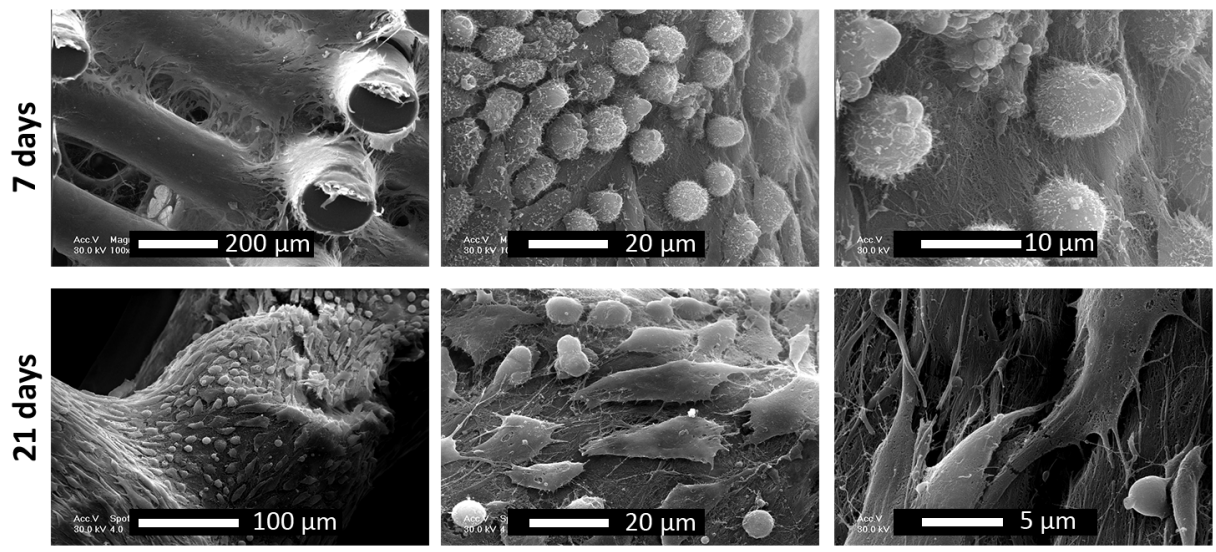

Figure 7.8: SEM micrographs of A: single chondrocyte-seeded and B: microaggregateseeded scaffolds at day 7 and day 21 of culture period. Collagen-like fibers, indicating ECMformation, were observed in all samples. Chondrocyte-microaggregates can be seen adhered to the scaffolds and showing the onset of cell spreading at day 7 of culture period. After 21 days of culture period the majority of the microaggregates gained a flattened appearance and collagen-like fibrils were observed indicating active ECM formation by the cells covering the surface of the scaffold. 
ples. Normalized band-area ratios for collagen content of single cell-seeded samples gradually decreased during the 21 day culture period, whereas the collagen content of the microaggregate-seeded samples had significantly increased during this period. Results obtained in this study suggest that seeding microaggregates, instead of single chondrocytes, seems to improve ECM formation and therefore potentially can be used to improve cartilage tissue engineered constructs. Future studies focus on studying matrix (and peri-cellular matrix) organization in scaffolds more in detail.

A limitation of the fiber-optic system was the inherent background signal generated by silica within the optical fiber. Careful data analysis using MATLAB revealed that bands at $920 \mathrm{~cm}^{-1}$ and $972 \mathrm{~cm}^{-1}$, attributed to ECM components were recoverable. The use of a new generation of fluorocarbon fiber-optic Raman probes, which generate a reference Raman band for quantitative Raman spectroscopy, will eliminate silica background signals and possibly lead to well-resolved Raman spectra of ECM $[37,53]$. If so and as opposed to the conventional Raman setups, which were only able to measure a relatively small volume of the scaffolds, this would allow collection of Raman spectra from multiple pores in tissue engineered scaffolds with one measurement in parallel. This generates a representation of the overall Raman signal from ECM within these scaffolds.

In order to further improve such analysis further investigation is needed to validate the potential of fiber optic evaluation of cartilaginous matrix formation in tissue engineered constructs. Additionally, more profound knowledge on the discrimination of specific collagen types is a key element to be considered in future studies.

\section{Acknowledgements}

The authors gratefully acknowledge the funding from the Dutch Program for Tissue Engineering (DPTE) through the grant number TGT. 6737, from the Netherlands Institute for Regenerative Medicine (NIRM) through the grant number FES0908 and from the National Institute of Health (NIH) through the grant number R01AR055222 and R01AR056646. C-28/I2 human immortalized chondrocyte cell line was established using cells derived from tissue that was provided by the National Disease Research Interchange. 


\section{References}

[1] Mankin HJ. The response of articular cartilage to mechanical injury. The Journal of bone and joint surgery American volume. 1982;64:460-6.

[2] Dudics V, Kunstar A, Kovacs J, Lakatos T, Geher P, Gomor B, et al. Chondrogenic potential of mesenchymal stem cells from patients with rheumatoid arthritis and osteoarthritis: measurements in a microculture system. Cells Tissues Organs. 2009;189:307-16.

[3] Zhang Z, McCaffery JM, Spencer RG, Francomano CA. Hyaline cartilage engineered by chondrocytes in pellet culture: histological, immunohistochemical and ultrastructural analysis in comparison with cartilage explants. J Anat. 2004;205:229-37.

[4] Kuettner KE. Biochemistry of articular cartilage in health and disease. Clinical biochemistry. 1992;25:155-63.

[5] Krafft C, et al. Mapping of single cells by near infrared Raman microspectroscopy. Vib Spectrosc. 2003;32:75-83.

[6] Notingher I, Verrier S, Romanska H, Bishop AE, Polak JM, Hench LL. In situ characterisation of living cells by Raman spectroscopy. Spectrosc-Int J. 2002;16:43-51.

[7] Puppels GJ, Olminkhof JH, Segers-Nolten GM, Otto C, de Mul FF, Greve J. Laser irradiation and Raman spectroscopy of single living cells and chromosomes: sample degradation occurs with $514.5 \mathrm{~nm}$ but not with $660 \mathrm{~nm}$ laser light. Exp Cell Res. 1991;195:361-7.

[8] Frushour BG, Koenig JL. Raman scattering of collagen, gelatin, and elastin. Biopolymers. 1975;14:379-91.

[9] Leikin S, Parsegian VA, Yang WH, Walrafen GE. Raman spectral evidence for hydration forces between collagen triple helices. Proceedings of the National Academy of Sciences of the United States of America. 1997;94:11312-7.

[10] Ellis R, Green E, Winlove CP. Structural Analysis of Glycosaminoglycans and Proteoglycans by Means of Raman Microspectrometry. Connect Tissue Res. 2009;50:29-36.

[11] Bansil R, Yannas IV, Stanley HE. Raman spectroscopy: a structural probe of glycosaminoglycans. Biochimica et biophysica acta. 1978;541:535-42.

[12] Kunstar A, Otto C, Karperien M, van Blitterswijk C, van Apeldoorn A. Raman Microspectroscopy: A Noninvasive Analysis Tool for Monitoring of Collagen-Containing Extracellular Matrix Formation in a Medium-Throughput Culture System. Tissue Eng Part C-Me. 2011;17:737-44.

[13] Jones JR, Vats A, Notingher L, Gough JE, Tolley NS, Polak JM, et al. In situ monitoring of chondrocyte response to bioactive scaffolds using Raman spectroscopy. Key Eng Mat. 2005;284286:623-6.

[14] Matousek P, Draper ERC, Goodship AE, Clark IP, Ronayne KL, Parker AW. Noninvasive Raman Spectroscopy of human tissue in vivo. Applied spectroscopy. 2006;60:758-63.

[15] Okagbare PI, Esmonde-White FWL, Goldstein SA, Morris MD. Transcutaneous Raman spectroscopy for assessing progress of bone graft incorporation in bone reconstruction and repair. Photonic Therapeutics and Diagnostics Vii. 2011;7883.

[16] Crow P, Molckovsky A, Uff J, Stone N, Wilson B, Wongkeesong LM. Fibre-optic raman spectrsocopy: The prospects for in vivo diagnosis of bladder and prostate cancer. J Urology. 2004;171:68.

[17] Shim MG, Song LMWM, Marcon NE, Wilson BC. In vivo near-infrared Raman spectroscopy: Demonstration of feasibility during clinical gastrointestinal endoscopy. Photochemistry and photobiology. 2000;72:146-50.

[18] Hata TR, Scholz TA, Ermakov IV, McClane RW, Khachik F, Gellermann W, et al. Non-invasive Raman spectroscopic detection of carotenoids in human skin. J Invest Dermatol. 2000;115:441-8.

[19] Mahadevan-Jansen A, Mitchell WF, Ramanujam N, Utzinger U, Richards-Kortum R. Development of a fiber optic probe to measure NIR Raman spectra of cervical tissue in vivo. Photochemistry and photobiology. 1998;68:427-31.

[20] Utzinger U, Heintzelman DL, Mahadevan-Jansen A, Malpica A, Follen M, Richards-Kortum R. Near-infrared Raman spectroscopy for in vivo detection of cervical precancers. Applied spectroscopy. 2001;55:955-9. 
[21] Buschman HP, Marple ET, Wach ML, Bennett B, Schut TCB, Bruining HA, et al. In vivo determination of the molecular composition of artery wall by intravascular Raman spectroscopy. Analytical chemistry. 2000;72:3771-5.

[22] Beumer GJ, van Blitterswijk CA, Ponec M. Biocompatibility of a biodegradable matrix used as a skin substitute: an in vivo evaluation. J Biomed Mater Res. 1994;28:545-52.

[23] Bakker D, van Blitterswijk CA, Hesseling SC, Grote JJ. Effect of implantation site on phagocyte/polymer interaction and fibrous capsule formation. Biomaterials. 1988;9:14-23.

[24] Beumer GJ, van Blitterswijk CA, Ponec M. Degradative behaviour of polymeric matrices in (sub)dermal and muscle tissue of the rat: a quantitative study. Biomaterials. 1994;15:551-9.

[25] Moroni L, Hendriks JA, Schotel R, de Wijn JR, van Blitterswijk CA. Design of biphasic polymeric 3-dimensional fiber deposited scaffolds for cartilage tissue engineering applications. Tissue Eng. 2007;13:361-71

[26] Mensik I, Lamme EN, Riesle J, Brychta P. Effectiveness and Safety of the PEGT/PBT Copolymer Scaffold as Dermal Substitute in Scar Reconstruction Wounds (Feasibility Trial). Cell Tissue Bank. 2002;3:245-53

[27] Meijer GJ, van Dooren A, Gaillard ML, Dalmeijer R, de Putter C, Koole R, et al. Polyactive as a bone-filler in a beagle dog model. International journal of oral and maxillofacial surgery. $1996 ; 25: 210-16$

[28] Du C, Meijer GJ, van de Valk C, Haan RE, Bezemer JM, Hesseling SC, et al. Bone growth in biomimetic apatite coated porous Polyactive $((\mathrm{R}))$ 1000PEGT70PBT30 implants. Biomaterials. 2002;23:4649-56.

[29] Napolitano AP, Chai P, Dean DM, Morgan JR. Dynamics of the self-assembly of complex cellular aggregates on micromolded nonadhesive hydrogels. Tissue engineering. 2007;13:2087-94.

[30] Nikolovski J, Mooney DJ. Smooth muscle cell adhesion to tissue engineering scaffolds. Biomaterials. 2000;21:2025-32. [31] Finger F, Schorle C, Zien A, Gebhard P, Goldring MB, Aigner T. Molecular phenotyping of human chondrocyte cell lines T/C-28a2, T/C-28a4, and C-28/I2. Arthritis and rheumatism. 2003;48:3395-403.

[32] Esmonde-White KA, Mandair GS, Raaii F, Jacobson JA, Miller BS, Urquhart AG, et al. Raman spectroscopy of synovial fluid as a tool for diagnosing osteoarthritis. Journal of Biomedical Optics. 2009;14:034013.

[33] van Manen HJ, Lenferink A, Otto C. Noninvasive imaging of protein metabolic labeling in single human cells using stable isotopes and Raman microscopy. Analytical chemistry. 2008;80:9576-82.

[34] Pully VV, Lenferink A, Otto C. Hybrid Rayleigh, Raman and two-photon excited fluorescence spectral confocal, microscopy of living cells. J Raman Spectrosc. 2010;41:599-608.

[35] Uzunbajakava N, Lenferink A, Kraan Y, Volokhina E, Vrensen G, Greve J, et al. Nonresonant confocal Raman imaging of DNA and protein distribution in apoptotic cells. Biophys J. 2003;84:396881.

[36] van Manen HJ, Kraan YM, Roos D, Otto C. Intracellular chemical imaging of heme-containing enzymes involved in innate immunity using resonance Raman microscopy. Journal of Physical Chemistry B. 2004;108:18762-71.

[37] Okagbare PI, Morris MD. Polymer-capped fiber-optic Raman probe for non-invasive Raman spectroscopy. Analyst. 2012;137:77-81.

[38] Cao A, Pandya AK, Serhatkulu GK, Weber RE, Dai H, Thakur JS, et al. A robust method for automated background subtraction of tissue fluorescence. J Raman Spectrosc. 2007;38:1199-205.

[39] Pizette S, Niswander L. BMPs are required at two steps of limb chondrogenesis: Formation of prechondrogenic condensations and their differentiation into chondrocytes. Dev Biol. 2000;219:23749.

[40] Tacchetti C, Quarto R, Nitsch L, Hartmann DJ, Cancedda R. In vitro morphogenesis of chick embryo hypertrophic cartilage. The Journal of cell biology. 1987;105:999-1006.

[41] Moreira Teixeira LS, Leijten JC, Sobral J, Jin R, van Apeldoorn AA, Feijen J, et al. High throughput generated micro-aggregates of chondrocytes stimulate cartilage formation in vitro and in vivo. Eur Cell Mater. 2012;23:387-99. 
[42] Cheng WT, Liu MT, Liu HN, Lin SY. Micro-Raman spectroscopy used to identify and grade human skin pilomatrixoma. Microscopy research and technique. 2005;68:75-9.

[43] Pudlas M, Brauchle E, Klein TJ, Hutmacher DW, Schenke-Layland K. Non-invasive identification of proteoglycans and chondrocyte differentiation state by Raman microspectroscopy. Journal of biophotonics. 2012 .

[44] Bonifacio A, Beleites C, Vittur F, Marsich E, Semeraro S, Paoletti S, et al. Chemical imaging of articular cartilage sections with Raman mapping, employing uni- and multi-variate methods for data analysis. Analyst. 2010;135:3193-204.

[45] O Faolain E, Hunter MB, Byrne JM, Kelehan P, McNamara M, Byrne HJ, et al. A study examining the effects of tissue processing on human tissue sections using vibrational spectroscopy. Vib Spectrosc. 2005;38:121-7.

[46] Vunjak-Novakovic G, Obradovic B, Martin I, Bursac PM, Langer R, Freed LE. Dynamic cell seeding of polymer scaffolds for cartilage tissue engineering. Biotechnol Progr. 1998;14:193-202.

[47] Mauck RL, Byers BA, Yuan X, Tuan RS. Regulation of cartilaginous ECM gene transcription by chondrocytes and MSCs in 3D culture in response to dynamic loading. Biomechanics and modeling in mechanobiology. 2007;6:113-25.

[48] Frank CJ, Mccreery RL, Redd DCB. Raman-Spectroscopy of Normal and Diseased Human Breast Tissues. Analytical chemistry. 1995;67:777-83.

[49] Krafft C, Neudert L, Simat T, Salzer R. Near infrared Raman spectra of human brain lipids. Spectrochim Acta A. 2005;61:1529-35.

[50] Duke PJ, Daane EL, Montufar-Solis D. Studies of chondrogenesis in rotating systems. J Cell Biochem. 1993;51:274-82.

[51] Naumann A, Dennis JE, Aigner J, Coticchia J, Arnold J, Berghaus A, et al. Tissue engineering of autologous cartilage grafts in three-dimensional in vitro macroaggregate culture system. Tissue Eng. 2004;10:1695-706.

[52] Wolf F, Candrian C, Wendt D, Farhadi J, Heberer M, Martin I, et al. Cartilage tissue engineering using pre-aggregated human articular chondrocytes. European cells \& materials. 2008;16:92-9.

[53] Okagbare PI, Morris MD. Fluorocarbon fiber-optic Raman probe for non-invasive Raman spectroscopy. Applied spectroscopy. 2012;66:728-30. 


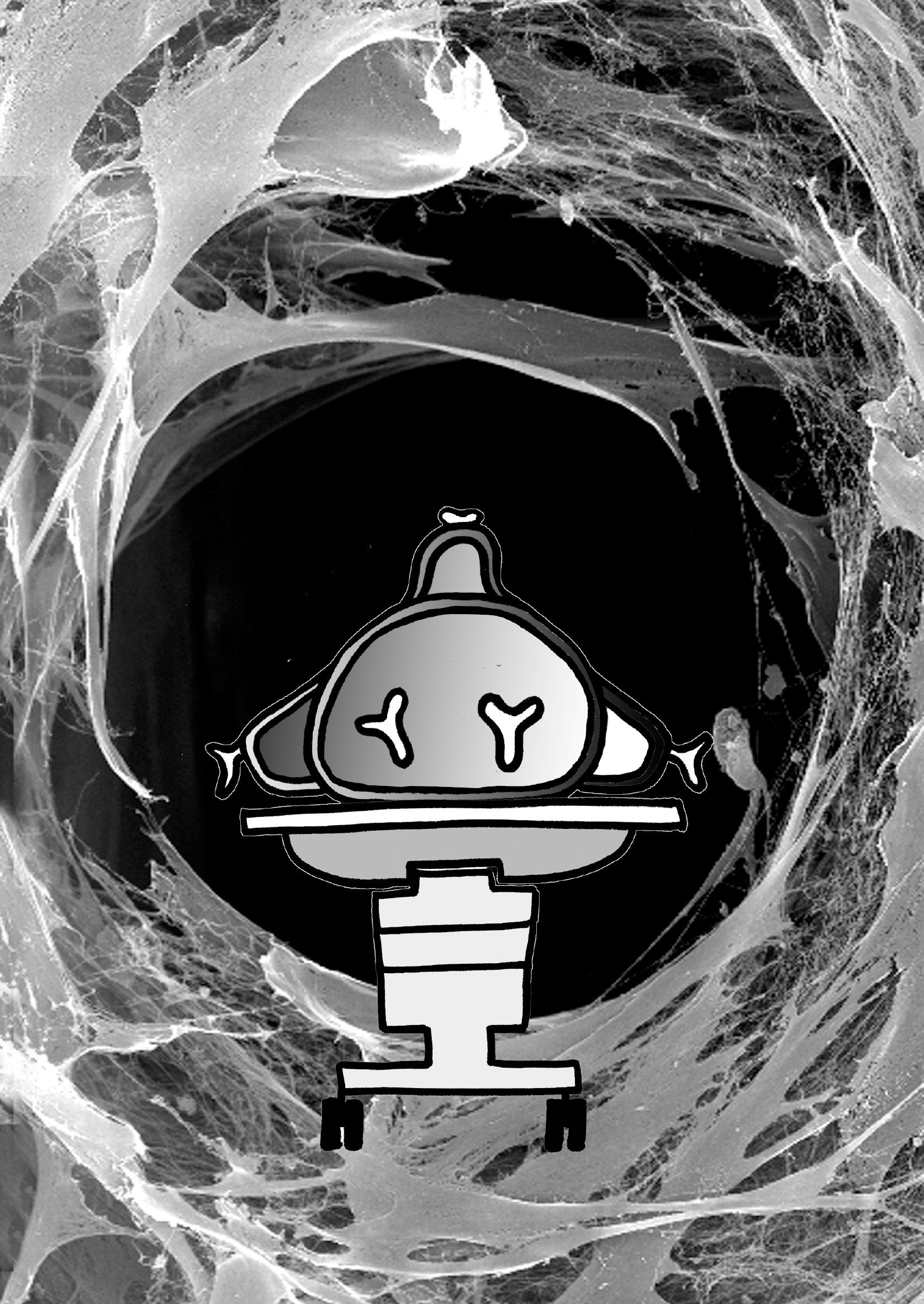




\title{
Chapter 8
}

\section{An open source image processing method to quantitatively assess tissue growth after non-invasive magnetic resonance imaging in human bone marrow stromal cell seeded 3D polymeric scaffolds}

\begin{abstract}
A. M. Leferink ${ }^{1}$, R. M. Fratila ${ }^{2}$, M. A. Koenrades ${ }^{1}$, C. A. van Blitterswijk ${ }^{1}$, A. H. Velders ${ }^{3,4}$ L. Moroni $^{1}$

${ }^{1}$ Department of Tissue Regeneration and ${ }^{2}$ NeuroImaging Group of MIRA - Institute for Biomedical Technology and Technical Medicine, University of Twente, Drienerlolaan 5, 7522 NB Enschede, The Netherlands ${ }^{3}$ Laboratory of SupraMolecular Chemistry and Technology of MESA - Institute for Nanotechnology, University of Twente, Drienerlolaan 5, 7522 NB Enschede, The Netherlands ${ }^{4}$ Laboratory of BioNanoTechnology, Agrotechnology and Food Sciences, Wageningen University, Dreijenplein 6, 6703 HB Wageningen, The Netherlands
\end{abstract}




\begin{abstract}
Monitoring extracellular matrix (ECM) components is one of the key methods used to determine tissue quality in three-dimensional scaffolds for regenerative medicine and clinical purposes. This is even more important when multipotent human bone marrow stromal cells (hMSCs) are used, as it could offer a method to understand in real time the dynamics of stromal cell differentiation and eventually steer it into the desired lineage. Magnetic Resonance Imaging (MRI) is a promising tool to overcome the challenge of a limited transparency in opaque three-dimensional (3D) scaffolds. Technical limitations of MRI involve non-uniform illumination leading to fluctuating background signals and therewith complicating quantifications on the retrieved images. We present a post-imaging processing sequence that is able to correct for this non-uniform illumination. To test the processing sequence we investigated the use of MRI for in vitro monitoring of tissue growth in three-dimensional poly(ethylene oxide terephthalate)poly(butylene terephthalate) (PEOT/PBT) scaffolds. Results showed that MRI, without the need to use contrast agents, is a promising non-invasive tool to quantitatively monitor ECM production and cell distribution during in vitro culture in $3 \mathrm{D}$ porous tissue engineered constructs.
\end{abstract}

Keywords: Magnetic resonance imaging, quantitative monitoring, imaging processing, scaffolds, tissue growth 


\subsection{Introduction}

A typical tissue engineering approach consists of combining cells with a synthetic or biological porous material called scaffold, which provides a mechanically stable environment to culture a substitute graft in vitro before implantation. Prior to implantation, several parameters including cellular distribution, extra cellular matrix (ECM) formation and tissue functionality need to be assessed. Monitoring in real-time these parameters is even more relevant when multipotent bone marrow stromal cells are used, as it is known that these cells can eventually progress into a non-desired cell phenotype when cultures on three-dimensional (3D) scaffolds are not controlled. For example, Jukes et al. and Scotti et al. showed that both embryonic and mesenchymal stem cells differentiate into a mature osteogenic lineage first passing by chondrogenesis $[1,2]$. Therefore, monitoring cell fate through analyzing the composition of the ECM that is formed in time would be a valuable tool to step from a conventional approach where scaffolds are treated as a "black-box" during culture to a new phase where the information obtained through monitoring could be used to steer cell differentiation into the targeted phenotype [3, 4].

Unfortunately, 3D scaffolds for tissue engineering strategies are often composed of polymeric materials with limited transparency. This property restricts the applicability of several imaging techniques like scanning electron microscopy, confocal microscopy, Raman spectroscopy and second harmonic generation imaging to superficial imaging of the constructs [5]. Histology is the most commonly used and most informative method to identify cells and ECM components inside scaffolds. However, this method does not allow for real-time monitoring of tissue growth since it requires sample fixation and processing. To be able to monitor cell growth and ECM formation over time by histological analysis, multiple samples have to be processed. Moreover, the obtained sections only represent part of the scaffold, which complicates the determination of cell growth and ECM formation for the whole construct. Micro-computed tomography $(\mu$-CT) can overcome these problems of limited transparency and sample preparation of a tissue engineered construct, but uses ionizing radiation and requires dense tissue to provide contrast [6]. Positron Emission Tomography (PET) and Single Photon Emission Computed Tomography (SPECT), generally combined with computed tomography (CT), can be used to localize and study tissue dynamics like tissue metabolism. However, these imaging modalities require the use of radioactive tracers $[7]$.

A promising approach to monitor cellular distribution and tissue formation in time in $3 \mathrm{D}$ is to use magnetic resonance imaging (MRI), also referred to as magnetic resonance microscopy (MRM) when applied with very high resolution, which is a noninvasive, non-ionizing and optionally label-free tool $[8,9]$. MRI has the capability to image thin slices of tissue with a sub-millimeter resolution in any orientation at any depth. Contrast in label-free MRI images is based, among others, on variations in tissue hydration or water/lipid ratios, which results in differences in the spin-phase and relaxation time of protons. For example, in previous work on magnetic resonance (MR) detection in bone tissue engineering approaches, an inverse relationship between MR relaxation times and mineral concentration was found after culturing osteoblasts on poly-(ethyl methacrylate) (PEMA) scaffolds [5]. A correlation between collagen 
orientation and T2 relaxation times was found in articular cartilage $[10,11]$ and in tendon under load [12]. In several other studies contrast agents were implemented in MRI to track cells both in vitro and in vivo [13]. Immobilization of contrast agents on nanoparticles to permit endocytosis is required for cell labeling $[14,15]$. After endocytosis of the contrast agent, depending on the type of contrast agent, accumulation of the agent leads to a darker or brighter signal, which will either reduce or increase the contrast between the labeled cells and the scaffolds [16]. A hurdle that has to be overcome is the possible loss of signal over time and/or increase in false positive signal both due to agent clearance or agent diffusion. Another challenge to take into account is that by incorporating MRI contrast agents to assess the quality of the tissue construct, the application of the labeled construct in the clinics might be complicated by regulations with respect to the exact formulation of the construct.
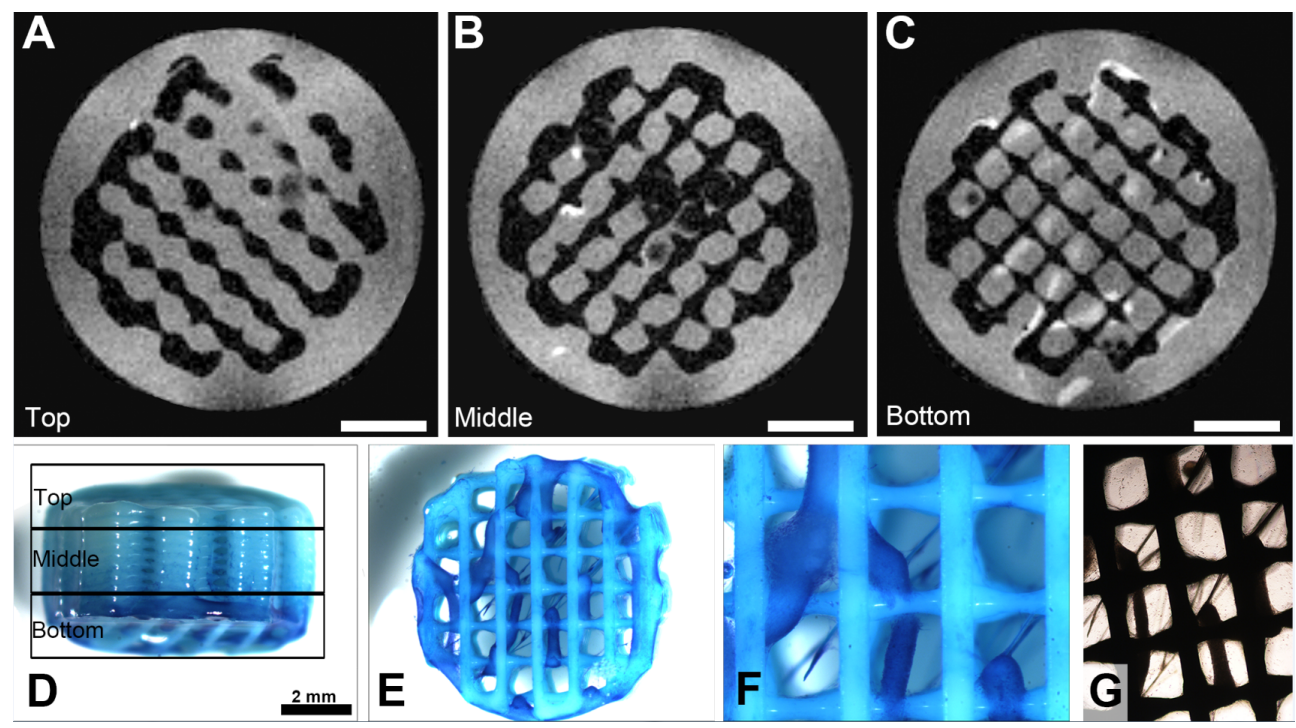

Figure 8.1: MRI scans of a scaffold after 14 days of culture with hMSCs (donor 1) taken with slice thicknesses of $80 \mu \mathrm{m}$ (A-C). Slices from one scan from the top (A), middle (B) and bottom (C) of the scaffold areas are represented, respectively, as indicated in the marques in (D) the side-view of the scaffold in which cells are stained with methylene blue. From the bottom-view of the scaffold, it can be seen that methylene blue stained hMSCs and ECM formed with the appearance of a dense string-like tissue distributed non-homogeneously throughout the scaffold (E-F). This was also observed during culture by bright field microscopy $(\mathrm{G})$. Scale bars represent $2 \mathrm{~mm}$.

Although contrast agents are already widely applied in clinical practice, their use is restricted to specific diagnostic procedures and limited to non-toxic doses. Labelfree micro-MRI has already been applied in tissue engineering approaches where dense tissues were assessed to detect for example collagen orientation and collagen mineralization $[11,17]$. However, the method of micro-MRI still has some challenges with respect to contrast with low tissue density, resolution, and background illumination inhomogeneities. In this study, we present a freely accessible method to retrieve quan- 
titative information in 3D by image processing and analysis of MRI data without the need to use contrast enhancing agents during scanning. To validate our image processing method we have cultured MSCs in 3D rapid prototyped scaffolds and quantified the tissue growth and distribution throughout the scaffolds after MRI.

\subsection{Materials and Methods}

\subsubsection{Isolation of human bone marrow derived stromal cells}

Bone marrow aspirates were obtained from patients who had given written informed consent. Human MSCs from two donors (donor 1: female, age 77; donor 2: female, age 55) were isolated and expanded as described previously [18] unless stated otherwise. Briefly, aspirates were resuspended using a 20-gauge needle, plated at a density of 50,000 cells $/ \mathrm{cm}^{2}$ and cultured in proliferation medium, which contains minimal essential medium (alpha-MEM; Life Technologies, Gaithersburg, MD), $10 \%$ heatinactivated fetal bovine serum (FBS; Lonza), $0.2 \mathrm{mM} \mathrm{L-Ascorbic} \mathrm{acid} \mathrm{2-phosphate}$ magnesium salt (ASAP, Sigma Aldrich), 2 mM L-glutamine (Gibco), 100 U/mL penicillin (Life Technologies), $10 \mu \mathrm{g} / \mathrm{mL}$ streptomycin (Life Technologies) and $1 \mathrm{ng} / \mathrm{mL}$ basic fibroblast growth factor (bFGF; Instruchemie, Delfzijl, The Netherlands). Cells were grown at $37{ }^{\circ} \mathrm{C}$ in a humidified atmosphere with $5 \% \mathrm{CO}_{2}$. Medium was refreshed twice per week and cells were used for further subculturing or cryopreservation on reaching near confluence.

\subsubsection{Fabrication of PEOT/PBT scaffolds}

Scaffold were fabricated of 300PEOT55PBT45 (PolyActive ${ }^{\mathrm{TM}} 300 / 55 / 45$, PolyVation, The Netherlands) which is a block copolymer with a weight ratio of 55 to 45 for the two PEOT and PBT components respectively, and a molecular weight of 300 Da for the PEG segments used in the co-polymerization process. Cylindrical porous scaffolds ( $8 \mathrm{~mm}$ in diameter by $3 \mathrm{~mm}$ in height) were fabricated as described before [19] by fused deposition modeling with a bioscaffolder (SysENG, Germany) with a fiber to fiber distance of $1000 \mu \mathrm{m}$, a fiber diameter of approximately $200 \mu \mathrm{m}$, and a layer thickness of $150 \mu \mathrm{m}$. These scaffolds were sterilized in $70 \%$ ethanol 2 times for 30 minutes each, washed in PBS first for 5 minutes and additionally for other 30 minutes two times, and finally incubated in culture medium overnight prior to cell culture.

\subsubsection{Cell seeding of PEOT/PBT scaffolds}

Scaffolds were dried and transferred to non-treated 24-well plates (NUNC). The scaffolds were seeded with 750,000 hMSCs (passage 3), harvested from monolayer expansion, in $100 \mu \mathrm{L}$ of proliferation medium, which was gently resuspended to fill all the pores of the scaffold. After 1.5 hour of incubation in the given volume, the medium was filled up to $500 \mu \mathrm{L}$. Proliferation medium was replaced twice a week for all samples. Constructs were cultured up to 60 days. 


\subsubsection{MRI equipment and measurements}

MRI experiments were performed at room temperature on a $14.1 \mathrm{~T}$ (600 MHz) Avance II NMR spectrometer from Bruker (Karlsruhe, Germany), equipped with a vertical narrow bore magnet, a Great B0 compensation unit, and 3 Great 1/60 amplifier units (X, Y, and Z). A micro 5 imaging probe with a $10 \mathrm{~mm}$ diameter saddle coil insert from Bruker (Karlsruhe, Germany) was used. Images were obtained using a multi-slicemulti-echo (MSME) sequence with the following parameters: repetition time (TR) $=1000 \mathrm{~ms}$, echo time $(\mathrm{TE})=10 \mathrm{~ms}$, flip angle $=90^{\circ}$, slice thickness $=0.07$ to $0.1 \mathrm{~mm}$, inter-slice gap $=0$, field of view $(\mathrm{FOV})=1 \mathrm{~cm}$, and $128 \times 128$ or $256 \times 256$ matrix. Samples were imaged in phosphate buffered saline (PBS) after fixation in $10 \%$ formalin to optimize scanning parameters. To investigate if non-targeted contrast agents can increase the contrast between water and lipids, one scaffold was imaged before and after addition of Endorem $\AA$, a T2 contrast agent based on superparamagnetic iron oxide (SPIO) nanoparticles. To investigate whether the tissue constructs can be kept in culture after a non-invasive MRI measurement, un-fixated samples were carefully transferred to a sterile MRI tube and imaged in culture media. Subsequently, samples were placed back in the culture plate and culture was continued.

\subsubsection{Image processing and quantification}

MRI images were processed in Fiji [20] prior to analysis to correct for non-uniform background illumination and to reduce noise. Background approximations were extracted from the top or bottom slice, where no scaffold and tissue material were present, by performing morphological opening with a disk shaped structuring element (radius 9). Background approximations were subtracted from the original image stack to remove the non-uniform illumination. A median filter (radius 2) was applied to the image stacks for noise reduction. After processing, only tissue structures appeared as bright regions, while water and scaffold material showed distinguishably lower intensities, enabling unique identification of constituents of interest. Images were segmented based on a single intensity threshold within a circular region of interest (ROI), comprising scaffold and surrounding water within the MRI glass tubes. Subsequently, morphological opening (radius 2) was applied to smooth the objects and remove outliers. Due to changing overall brightness and intensities between different experiments, the threshold had to be set for each experiment individually. To identify tissue material the threshold was set as such that a bare scaffold, without the presence of cells, showed a limited amount of false positive signal. The retrieved binary images were quantitatively analyzed. The area of the identified objects was computed in a section-by-section (top, middle, bottom) manner to provide volumetric densities throughout the scaffolds.

\subsubsection{D visualization}

Triangulated 3D surface meshes were created from the binary images for both scaffold and tissue material, using the integrated marching cubes algorithm in the BoneJ plugin (resampling factor 1 and 2 respectively) [21, 22]. The mesh models were imported into MeshLab (v.1.3.2), an open source tool developed with the support of 
the 3D-CoForm project, to render 3D models comprising tissue material and scaffold. A non-shrinking Taubin filter was applied to smooth the objects [23]. Surfaces were flat-shaded to enhance the faceting effect.

\subsubsection{Methylene blue staining}

To localize cells in the 3D scaffold prior to imaging with MRI, samples were washed gently with PBS, fixated in $10 \%$ formalin for 30 minutes and subsequently stained for 60 seconds using a $1 \%$ methylene blue solution in $0.1 \mathrm{M}$ borax buffer $(\mathrm{pH}=8.5$, Sigma). Scaffolds were subsequently washed with demineralized (DI) water until the water was clear. The scaffolds were imaged with a Nikon SMZ800 Stereomicroscope equipped with a QImaging Retiga 1300 camera.

\subsubsection{Scanning Electron Microscopy (SEM)}

Cell morphology and attachment was characterized by SEM analysis with a Philips XL 30 ESEM-FEG. Samples were fixated for 30 minutes in $10 \%$ formalin. Subsequently the samples were dehydrated in sequential ethanol series and critical point dried from liquid carbon dioxide using a Balzers CPD 030 Critical Point Dryer. The constructs were gold sputter coated (Cressington) prior to SEM analysis.

\subsubsection{Histological analysis}

After MRI measurements, samples were dehydrated using a sequential ethanol series (60, 70, 80, 90, 96 and 100\% ethanol, 30 minutes for each step), and subsequently embedded in glycol methacrylate (GMA). The obtained blocks were sectioned at 5 $\mu \mathrm{m}$ intervals, and stained with hematoxylin and eosin (H\&E, Sigma) for visualization of the nuclei and cytoplasm.

\subsection{Results}

\subsubsection{Detection of tissue on planar MRI images}

MRI measurements were successfully performed on a PEOT/PBT scaffold seeded with hMSCs after 14 days of static culture (Figure 8.1A-C). Prior to imaging the cells were fixated with $10 \%$ formalin and stained with methylene blue to localize tissue and cells (Figure 8.1D-F). The MRI images showed a high contrast between the scaffold material (black), water (grey) and tissue-like material containing lipids (white) (Figure 8.1C). As confirmed by methylene blue staining, the majority of the cells were found in the bottom layers of the scaffold. From the bottom-view of the scaffold shown in Figure 8.1E and $1 \mathrm{~F}$ similar string-like tissue patterns were found as in the MR images of the bottom slices (Figure 8.1C). Also, bright field microscopy during culture prior to fixation showed this same tissue distribution (Figure 8.1G). 

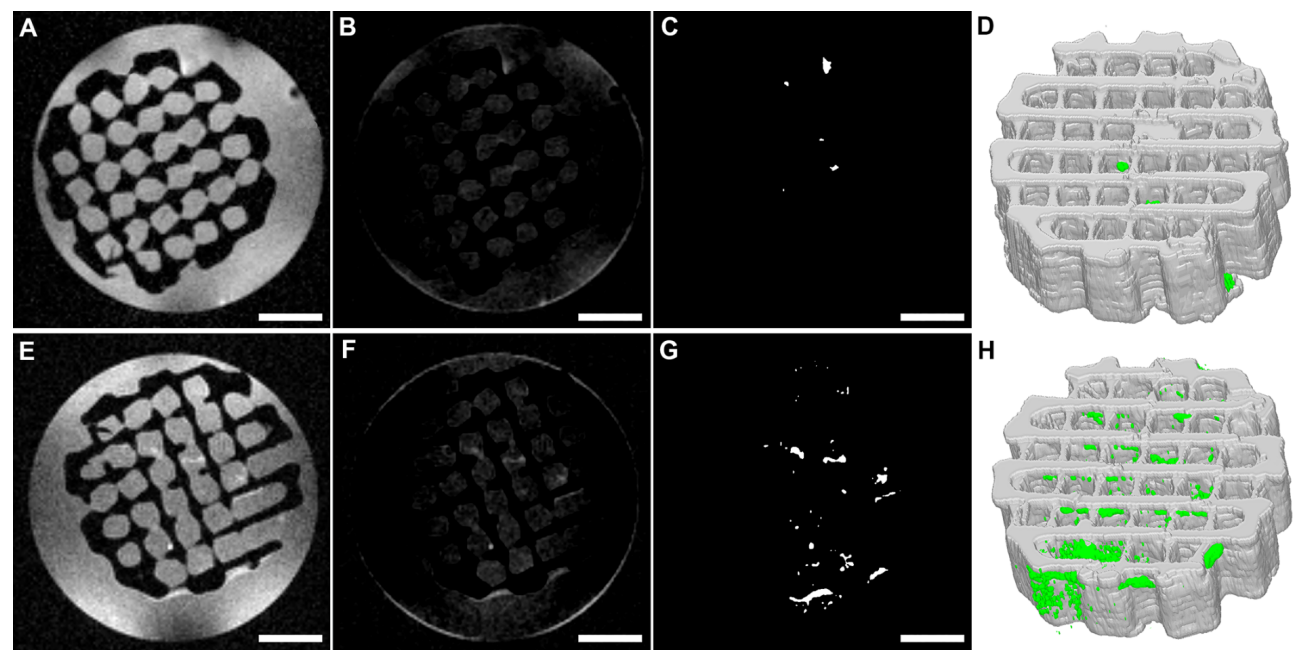

Figure 8.2: Image processing steps on MRI-derived image stacks in the absence (top, images A-D) and presence (bottom, images E-H) of hMSCs (donor 1; 5 weeks of culture). A and $\mathrm{E}$ represent the unprocessed $\mathrm{MR}$ images; $\mathrm{B}$ and $\mathrm{F}$ the images after background subtraction; $\mathrm{C}$ and $\mathrm{G}$ show the results of segmentation; $\mathrm{D}$ and $\mathrm{H}$ are the obtained 3D mesh models, representing the tissue localization, amounts and density. Scale bars represent $2 \mathrm{~mm}$.

\subsubsection{Image processing and $3 \mathrm{D}$ visualization}

The results of the major processing steps and the retrieved 3D models are shown in Figure 8.2. When comparing the two 3D models without and with hMSCs after 5 weeks of static culture (Figure $8.2 \mathrm{D}$ and $2 \mathrm{H}$ respectively) tissue was clearly detected in the scaffold cultured with hMSCs. The bare scaffolds showed tiny air bubble entrapment which in some planes led to closure of the pores in the model, since the air bubbles resulted in dark areas with bright edges on the interface with the surrounding water.

\subsubsection{The effect of Endorem(B) contrast agent on the reliability of the 3D models}

To investigate whether the use of an untargeted contrast agent would increase the contrast between the different materials present in the scaffold structure, two scans were performed subsequently on one scaffold which was statically cultured with hMSCs (donor 2) for 5 weeks. Figure 8.3 shows the results from planar scans at different heights in the scaffold. The contrast between tissue and free water was increased after the addition of Endorem $\AA$, while the contrast between free water and scaffold material was reduced. This resulted in an inaccurate segmentation of the scaffold (Figure $8.3 \mathrm{~F}$, L and R), leading to closure of the scaffold pores upon 3D modelling, which can be seen in the bottom-view (Figure 8.3T). 


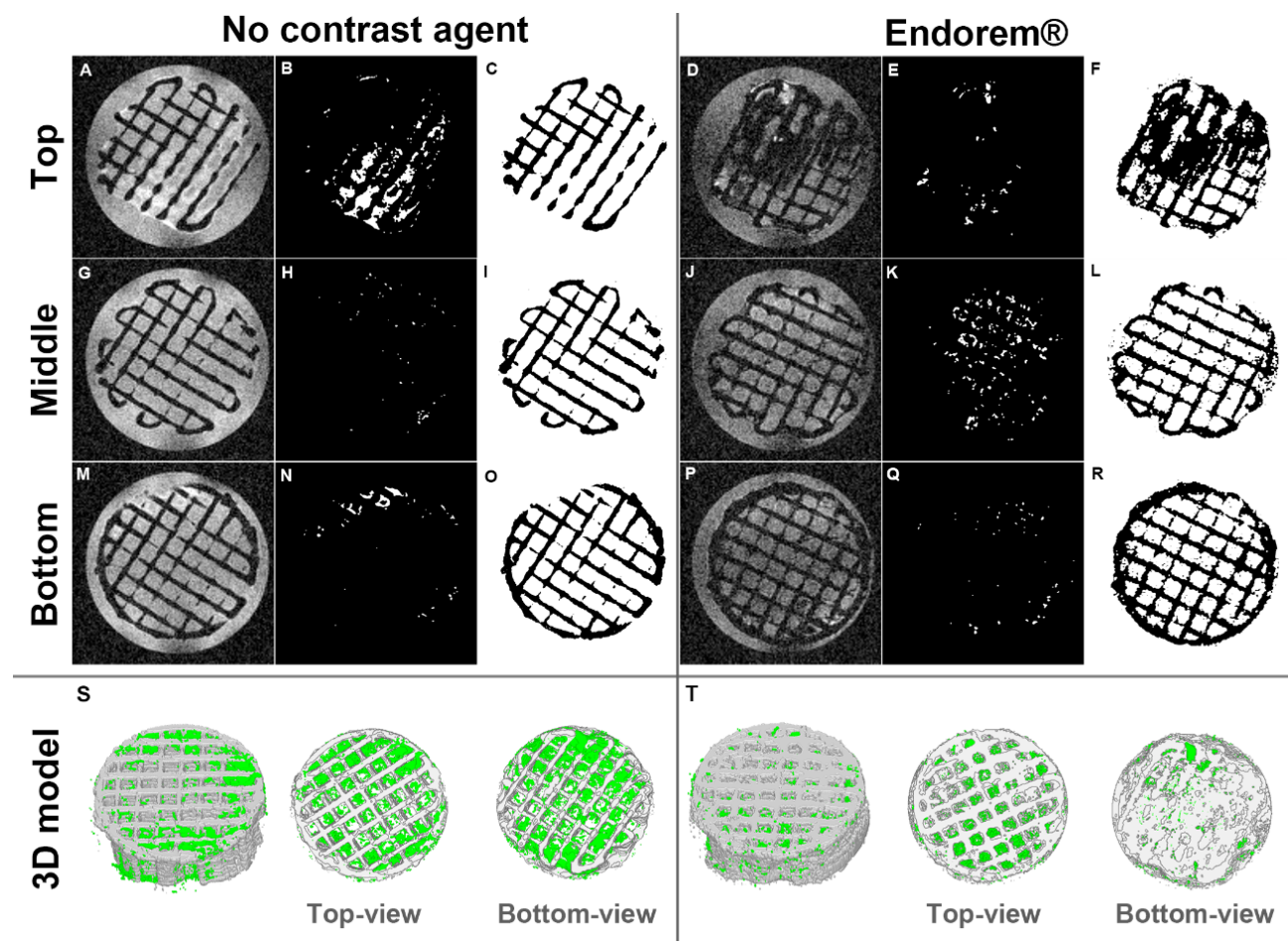

Figure 8.3: MRI scans of the top, middle and bottom of the scaffold after 5 weeks of culture obtained without the use of any contrast agents (A, G and M) and after the addition of Endorem $\AA \mathrm{T}_{2}$ contrast agent $(\mathrm{D}, \mathrm{J}$ and $\mathrm{P})$. Tissue is identified and appears white after image processing (B, H, N, E, K and Q). Scaffold material is extracted from unprocessed images by image processing sequences (C, I, O, F, L and R). By a mathematical combination of the images representing tissue-material and the images displaying scaffold material, a $3 \mathrm{D}$ model could be retrieved ( $\mathrm{S}$ and $\mathrm{T}$ ).

\subsubsection{Quantification of tissue distribution throughout the 3D scaffold}

After image processing the retrieved binary images can be used for quantification. One direct measure for tissue distribution was obtained by determination of the number of pixels per slice that was identified to represent tissue. By determination of the average of these numbers of pixels per slice over specific sub-volumes of the complete construct (Figure 8.4A) information was retrieved on the amount of tissue in the bottom, middle and top of the scaffold as presented in Figure 8.4B ( $\mathrm{n}=10$ slices per presented volume). These results were confirmed by bright field microscopy observation and SEM analysis in which a cell sheet is found at the top and at the bottom of the scaffold (Figure $8.4 \mathrm{C}$ and $4 \mathrm{E}$ ), while in a cross-sectional view lower numbers of cells were found in the interior of the scaffolds (Figure $8.4 \mathrm{D}$ ). This observation is further confirmed by histological analysis (Figure 8.4F-H). 
A

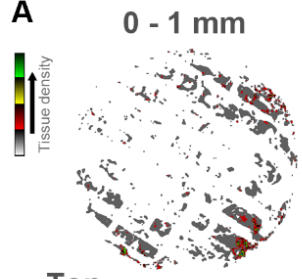
Top Middle
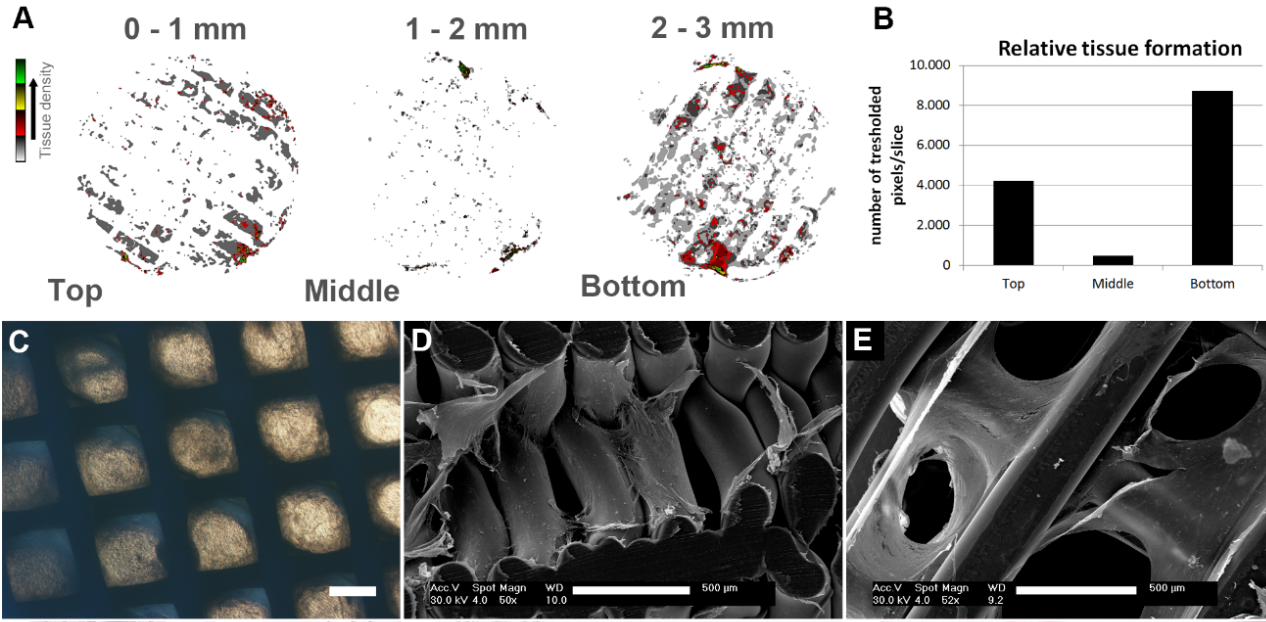

Bottom
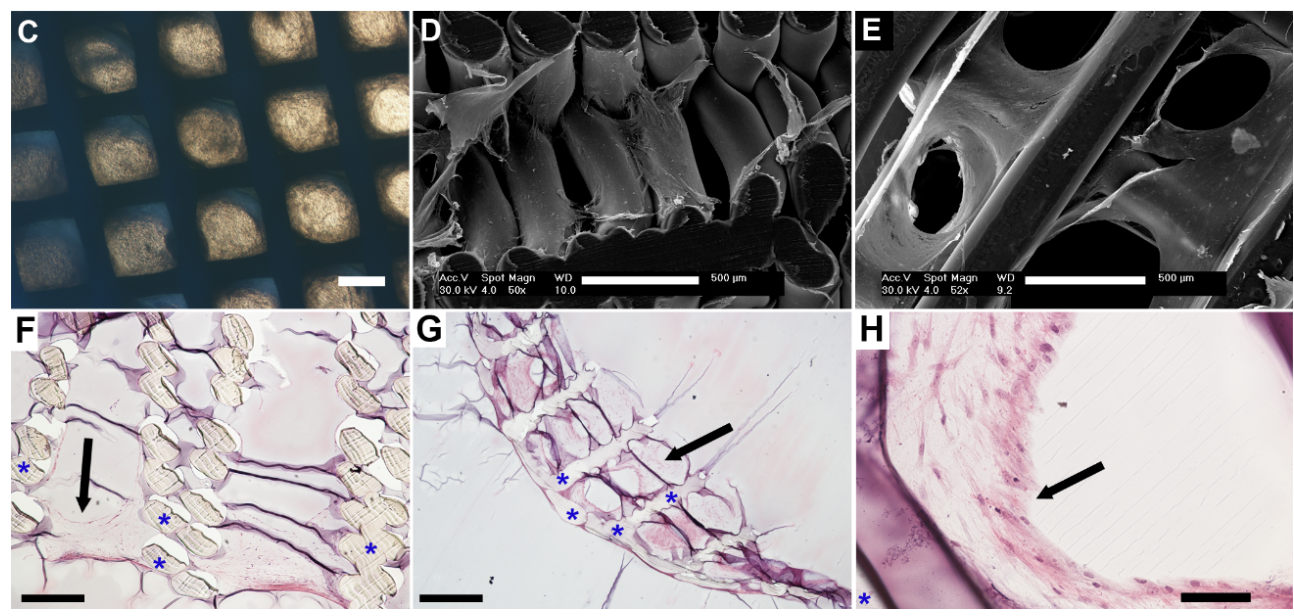

Figure 8.4: Processed images can be used to quantify tissue formation with high spatial resolution throughout the $3 \mathrm{D}$ construct. Z-stacks were retrieved by summarizing multiple slices into one projection as a 5 stage look-up table (A). The colours represent the amount of tissue in the $\mathrm{x}-\mathrm{y}$ plane over the full thickness of the projection as indicated by the legend. By determination of the average number of pixels representing tissue over a subset of slices, an indication of tissue presence in different areas of the scaffold can be given $(n=10$ slices per presented volume) (B). Bright field microscopy observation showed a homogeneous distribution of cells and tissue between the pores in the $\mathrm{x}-\mathrm{y}$ plane, by varying the focal plane upon observation an impression of pore filling per scaffold part can be retrieved (C). By SEM analysis on a top-to-bottom cross-section of the scaffold, tissue is observed throughout the scaffold. (D) Yet, from the bottom-view was observed that large cell sheets were found on the bottom of the scaffold (E). This finding was confirmed by histological analysis of a top-to-bottom cross-section of a construct (F). From a section of the bottom layer of the scaffold it can be observed that the tissue forms circular patterns in the pores of the scaffolds $(\mathrm{G}, \mathrm{H})$. Arrows indicate cells and tissue, asterisks indicate scaffold material. Scale bars represent (C, D, E and F) $500 \mu \mathrm{m}$, (G) $1 \mathrm{~mm}$ and (H) $100 \mu \mathrm{m}$. 


\subsection{Discussion}

Currently, many studies focus on monitoring hMSCs fate in tissue engineered constructs in 3D. Most conventional methods to study cell growth and distribution are based on destructive methods such as histological analysis and biochemical assays. Non-invasive imaging modalities are promising tools to non-destructively and ultimately longitudinally or continuously monitor tissue development in 3D. Magnetic resonance modalities have gained interest in the field of tissue engineering for several years.

First, nuclear magnetic resonance spectroscopy (NMR) has been applied to monitor metabolites in tissue engineered constructs [24]. More recently, MRI has been applied because of the capability to distinguish between several tissue types and densities such as collagens, mineralized tissues and soft tissues [8, 12, 17, 25-28]. Contrast with a sub-mm scale resolution in MRI is obtained by variations in proton dynamics which results in different water proton transverse $\left(\mathrm{T}_{2}\right)$ relaxation times and magnetization transfer ratios [10]. Burg et al. have observed that the signal intensity in MRI on 3D scaffolds was higher in cells than in the liquid phase and scaffold material [29]. The obtained contrast allowed them to observe cellular distribution in formalin fixated tissue constructs.

Abarrategi et al. have shown to successfully assess the distribution of MSCs in 3D rapid prototyped polymeric and ceramic scaffolds without formalin fixation [25]. However, the seeding density of the constructs was relatively high with $5 \times 10^{6}$ cells/ scaffold on a cylindrical scaffold with a diameter of $4.5 \mathrm{~mm}$ and a height of $3 \mathrm{~mm}$. We observed that lower densities of cells as applied in our study $\left(7.5 \times 10^{5}\right.$ cells $)$ in a cylindrical scaffold with a diameter of $8 \mathrm{~mm}$ and a height of $3 \mathrm{~mm}$ results in limited contrast. Furthermore, non-uniformity of intensity, which we also observed in the work of Abarrageti, complicates quantification of tissue development [30, 31]. To overcome these technical challenges, we presented a sequence of freely accessible image post-imaging processing steps to be able to quantify tissue growth in low density tissue constructs. Our method allowed for the identification of tissue formation in opaque mm-sized 3D scaffolds from MRI-derived image stacks. In contrast to studies that require contrast agents to localize cells, we showed that the most accurate $3 \mathrm{D}$ models of cell and tissue distribution within solid scaffolds can be obtained without the use of contrast agents.

Several studies have reported on MRI analysis in vitro after fixation of the samples in formalin [25, 32, 33]. Studies of Fishbein et al. and Zheng et al. showed that phosphate salts and fixation solutions have an influence on the relaxation times of water protons, attributed to the physicochemical interactions (e.g. noncovalent binding or chemical exchange) of free water with polyoxymethylene oligomers formed when formaldehyde is dissolved in water. Changes in proton dynamics in these studies were found in native cartilage tissues, in which the fixatives also showed to influence the composition of cartilage over time. In our study, an un-fixated sample was also imaged, subsequently fixated and imaged again, after which there was no evidence found for a difference in contrast or signal intensity after histogram based analysis (data not shown). We therefore hypothesize that the influence of fixatives on proton dynamics did not interfere with the post-imaging processing method presented here. 
To label-free monitor tissue growth longitudinally in $3 \mathrm{D}$, without interrupting the culture phase, we believe that MRI will be a valuable tool which allows for the maintenance of sterile culture conditions during scanning by controlling temperature and gas exchange, without compromising the quality of the images [34]. Furthermore, targeted contrast agents such as antibody functionalized iron oxide magnetic beads could be developed to be able to characterize the type of tissue formed by for example distinguishing between collagen-type- 1 and collagen-type- 2 in the ECM. By applying our optimized image processing sequences, the required duration of scanning could be reduced. The processing sequence proved to overcome specific technical limitations which are currently compromised by longer scanning times to be able to average over more multiple signals per voxel.

\subsection{Conclusion}

The free-of-charge post-imaging processing sequence presented in this study can be a valuable tool to overcome technical limitations of image analysis after MRI. We have shown that our method enables the identification and quantitative localization of tissue in 3D opaque constructs for tissue engineering approaches. Identified tissue distribution was quantified from the image stacks, visualized in $3 \mathrm{D}$ mesh models and confirmed qualitatively by histological analysis. In the future, optimized postimage processing sequences can help to access shorter scanning times and improved resolution of tissue engineered constructs prior to implantation.

\section{Acknowledgement}

The authors gratefully acknowledge the funding from the Netherlands Institute for Regenerative Medicine (NIRM) through the grant number FES0908. 


\section{References}

[1] Jukes JM, Both SK, Leusink A, Sterk LM, van Blitterswijk CA, de Boer J. Endochondral bone tissue engineering using embryonic stem cells. Proc Natl Acad Sci U S A. 2008;105:6840-5.

[2] Scotti C, Tonnarelli B, Papadimitropoulos A, Scherberich A, Schaeren S, Schauerte A, et al. Recapitulation of endochondral bone formation using human adult mesenchymal stem cells as a paradigm for developmental engineering. Proc Natl Acad Sci U S A. 2010;107:7251-6.

[3] Baradez MO, Marshall D. The use of multidimensional image-based analysis to accurately monitor cell growth in 3D bioreactor culture. Plos One. 2011;6:e26104.

[4] Chen WL, Huang CH, Chiou LL, Chen TH, Huang YY, Jiang CC, et al. Multiphoton imaging and quantitative analysis of collagen production by chondrogenic human mesenchymal stem cells cultured in chitosan scaffold. Tissue Eng Part C Methods. 2010;16:913-20.

[5] Washburn NR, Weir M, Anderson P, Potter K. Bone formation in polymeric scaffolds evaluated by proton magnetic resonance microscopy and X-ray microtomography. Journal of Biomedical Materials Research Part A. 2004;69A:738-47.

[6] Barbetta A, Bedini R, Pecci R, Dentini M. Role of X-ray microtomography in tissue engineering. Ann I Super Sanita. 2012;48:10-8.

[7] Kofidis T, Lenz A, Boublik J, Akhyari P, Wachsmann B, Mueller-Stahl K, et al. Pulsatile perfusion and cardiomyocyte viability in a solid three-dimensional matrix. Biomaterials. 2003;24:5009-14.

[8] Xu HH, Othman SF, Magin RL. Monitoring Tissue Engineering Using Magnetic Resonance Imaging. J Biosci Bioeng. 2008;106:515-27.

[9] Appel AA, Anastasio MA, Larson JC, Brey EM. Imaging challenges in biomaterials and tissue engineering. Biomaterials. 2013;34:6615-30.

[10] Nissi MJ, Rieppo J, Toyras J, Laasanen MS, Kiviranta I, Jurvelin JS, et al. T(2) relaxation time mapping reveals age- and species-related diversity of collagen network architecture in articular cartilage. Osteoarthritis Cartilage. 2006;14:1265-71.

[11] Xia Y, Moody JB, Burton-Wurster N, Lust G. Quantitative in situ correlation between microscopic MRI and polarized light microscopy studies of articular cartilage. Osteoarthritis Cartilage. 2001;9:393-406.

[12] Mountain KM, Bjarnason TA, Dunn JF, Matyas JR. The functional microstructure of tendon collagen revealed by high-field MRI. Magnetic resonance in medicine : official journal of the Society of Magnetic Resonance in Medicine / Society of Magnetic Resonance in Medicine. 2011;66:520-7.

[13] Ramaswamy S, Greco JB, Uluer MC, Zhang ZJ, Zhang ZL, Fishbein KW, et al. Magnetic Resonance Imaging of Chondrocytes Labeled with Superparamagnetic Iron Oxide Nanoparticles in Tissue-Engineered Cartilage. Tissue Eng Pt A. 2009;15:3899-910.

[14] Bhirde A, Xie J, Swierczewska M, Chen X. Nanoparticles for cell labeling. Nanoscale. 2011;3:14253.

[15] Hachani R, Lowdell M, Birchall M, Thanh NTK. Tracking stem cells in tissue-engineered organs using magnetic nanoparticles. Nanoscale. 2013;5:11362-73.

[16] Yang CY, Tai MF, Chen ST, Wang YT, Chen YF, Hsiao JK, et al. Labeling of human mesenchymal stem cell: Comparison between paramagnetic and superparamagnetic agents. J Appl Phys. 2009;105:-.

[17] Chesnick IE, Mason JT, Giuseppetti AA, Eidelman N, Potter K. Magnetic resonance microscopy of collagen mineralization. Biophysical Journal. 2008;95:2017-26.

[18] de Bruijn JD, van den Brink I, Mendes S, Dekker R, Bovell YP, van Blitterswijk CA. Bone induction by implants coated with cultured osteogenic bone marrow cells. Advances in dental research. 1999;13:74-81.

[19] Moroni L, de Wijn JR, van Blitterswijk CA. Three-dimensional fiber-deposited PEOT/PBT copolymer scaffolds for tissue engineering: influence of porosity, molecular network mesh size, and swelling in aqueous media on dynamic mechanical properties. Journal of biomedical materials research. 2005;75:957-65.

[20] Schindelin J, Arganda-Carreras I, Frise E, Kaynig V, Longair M, Pietzsch T, et al. Fiji: an 
open-source platform for biological-image analysis. Nature Methods. 2012;9:676-82.

[21] Lorensen WE, Cline HE. Marching cubes: A high resolution 3D surface construction algorithm. ACM SIGGRAPH Computer Graphics. 1987;21:163-9.

[22] Doube M, Klosowski MM, Arganda-Carreras I, Cordelieres FP, Dougherty RP, Jackson JS, et al. BoneJ Free and extensible bone image analysis in ImageJ. Bone. 2010;47:1076-9.

[23] Taubin G. A signal processing approach to fair surface design. Proceedings of the 22nd annual conference on Computer graphics and interactive techniques: ACM; 1995. p. 351-8.

[24] Constantinidis I, Sambanis A. Noninvasive monitoring of tissue-engineered constructs by nuclear magnetic resonance methodologies. Tissue engineering. 1998;4:9-17.

[25] Abarrategi A, Fernandez-Valle ME, Desmet T, Castejon D, Civantos A, Moreno-Vicente C, et al. Label-free magnetic resonance imaging to locate live cells in three-dimensional porous scaffolds. J R Soc Interface. 2012;9:2321-31.

[26] Kotecha M, Klatt D, Magin RL. Monitoring cartilage tissue engineering using magnetic resonance spectroscopy, imaging, and elastography. Tissue Eng Part B Rev. 2013;19:470-84.

[27] Neves AA, Medcalf N, Smith M, Brindle KM. Evaluation of engineered meniscal cartilage constructs based on different scaffold geometries using magnetic resonance imaging and spectroscopy. Tissue engineering. 2006;12:53-62.

[28] Peptan IA, Hong L, Xu HH, Magin RL. MR assessment of osteogenic differentiation in tissueengineered constructs. Tissue engineering. 2006;12:843-51.

[29] Burg KJ, Delnomdedieu M, Beiler RJ, Culberson CR, Greene KG, Halberstadt CR, et al. Application of magnetic resonance microscopy to tissue engineering: a polylactide model. J Biomed Mater Res. 2002;61:380-90.

[30] Belaroussi B, Milles J, Carme S, Zhu YM, Benoit-Cattin H. Intensity non-uniformity correction in MRI: existing methods and their validation. Medical image analysis. 2006;10:234-46.

[31] Milles J, Zhu YM, Gimenez G, Guttmann CR, Magnin IE. MRI intensity nonuniformity correction using simultaneously spatial and gray-level histogram information. Computerized medical imaging and graphics : the official journal of the Computerized Medical Imaging Society. 2007;31:8190.

[32] Fishbein KW, Canuto HC, Bajaj P, Camacho NP, Spencer RG. Optimal methods for the preservation of cartilage samples in MRI and correlative biochemical studies. Magnetic resonance in medicine : official journal of the Society of Magnetic Resonance in Medicine / Society of Magnetic Resonance in Medicine. 2007;57:866-73.

[33] Zheng S, Xia Y. Changes in Proton Dynamics in Articular Cartilage Caused by Phosphate Salts and Fixation Solutions. Cartilage. 2010;1:55-64.

[34] Crowe JJ, Grant SC, Logan TM, Ma T. A magnetic resonance-compatible perfusion bioreactor system for three-dimensional human mesenchymal stem cell construct development. Chem Eng Sci. 2011;66:4138-47. 


\section{Chapter 9}

\section{A future outlook}

\section{Unraveling the black box: An antibody based approach with the potential for multi-coloring osteogenic and chondrogenic proteins in tissue engineered constructs}

\footnotetext{
A .M. Leferink ${ }^{1}$, D. Santos ${ }^{1}$, C. A. van Blitterswijk ${ }^{1,2}$, L. Moroni ${ }^{1,2}$

${ }^{1}$ Department of Tissue Regeneration of MIRA -Institute for Biomedical Technology and Technical Medicine, University of Twente, The Netherlands ${ }^{2}$ Department of Complex Tissue Regeneration, Faculty of Health and Science, University of Maastricht
} 


\begin{abstract}
When tissue engineering strategies rely on the combination of threedimensional (3D) polymeric or ceramic scaffolds with cells to culture implantable tissue construct in vitro, it is desirable to monitor tissue growth and cell fate to be able to more rationally predict the quality and success of the construct upon implantation. Such a 3D construct is often referred to as a 'black-box' since the properties of the scaffolds material limit the applicability of most imaging modalities to assess important construct parameters. These parameters include the number of cells, the amount and type of tissue formed and the distribution of cells and tissue throughout the construct. Immunolabeling enables the spatial and temporal identification of multiple tissue types within one scaffold without the need to sacrifice the construct. In this report, we concisely review the applicability of antibodies (Abs) and their conjugation chemistries in tissue engineered constructs. With some preliminary experiments, we show an efficient conjugation strategy to couple extracellular matrix (ECM) Abs to fluorophores. The conjugated probes proved to be effective in determining the presence of collagen type I on electrospun and rapid prototyped scaffolds seeded with adult mesenchymal stromal cells. The conjugation chemistry applied in our proof of concept study is expected to be applicable in the coupling of any other fluorophore or particle to the Abs. This could ultimately lead to a library of probes to permit high-contrast imaging by several imaging modalities.
\end{abstract}

Keywords: Bone marrow stromal cells, extra cellular matrix, collagen, immunofluorescence, antibodies 


\subsection{Introduction}

Tissue engineering approaches for cartilage and bone regeneration often involve the use of three-dimensional (3D) synthetic polymeric or ceramic scaffolds with a certain mechanical integrity to mimic the natural native environment. Scaffolds can be implanted directly into the defect site, in which they are expected to attract cells and facilitate tissue ingrowth. Another approach is based on in vitro culture of scaffolds combined with autologous (stem) cells to be able to control culture parameters and therewith steer the cell fate and tissue growth into a desired lineage. In both cases, our understanding of the biological phenomena occurring within the pore network of $3 \mathrm{D}$ scaffolds is often limited. Real time monitoring of such phenomena offers a tool to also advance the design of scaffolds which can better control cell fate and tissue growth. However, current imaging techniques are hindered by the scaffolds limited transparency, scaffolds geometry and a lack of available methods to non-invasively assess cells and tissues functionality.

In the past few decades, the need for non-invasive monitoring methods has been widely acknowledged with a special focus on monitoring with a spatio-temporal resolution. Several imaging methods have been opted to overcome transparency issues, such as ultrasound, nuclear, photoacoustic, X-ray and magnetic resonance (MR) based imaging modalities [1]. X-ray and MR imaging have shown to be promising tools in quantification of mineralization in bone tissue engineering $[2,3]$. However, to date none of these methods enables the detection of multiple early tissue lineage markers with a single cell-resolution in $3 \mathrm{D}$ without the need to combine several imaging modalities.

The evolution of bio-conjugation chemistry has significantly contributed to the development of novel and successful methods to label multiple components within a single construct for imaging purposes. Antibodies (Abs) stand out as probes due to their specificity, affinity and versatility to target tissue specific components. In this report, we review currently available immunolabels to target among others bone and cartilage extra cellular matrix (ECM) components. Subsequently, we will propose a method for the functionalization of Abs to target collagen type I and collagen type II, which are abundantly present in bone and cartilage, respectively. In our preliminary studies, fluorophores are used as a model label; however, the protocol can be applied on any other label by similar conjugation chemistry.

\subsection{Cartilage and Bone}

Cartilage is a dense connective tissue which can be classified in three different types dependent on the ECM composition and function [4]. The first class is hyaline cartilage and can be found in the joints, ribs, nose, trachea and larynx. Elastic cartilage is found in the ear, epiglottis and larynx, and fibrous cartilage is found in the intervertebral discs. The main focus in cartilage tissue engineering is on hyaline cartilage in the joints, referred to as articular cartilage [5]. Cartilage is produced by chondrocytes and finds its function in absorbing impact forces, transferring loads to the underlying bone and allowing low-friction movement of the joint $[6,7]$. In its healthy mature 
A

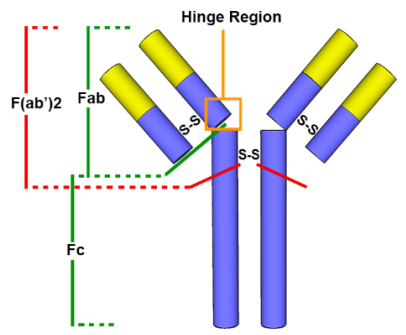

C

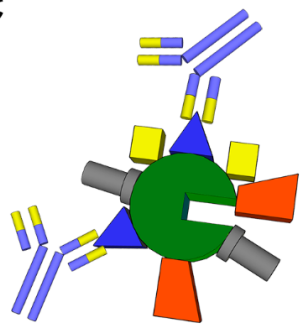

B
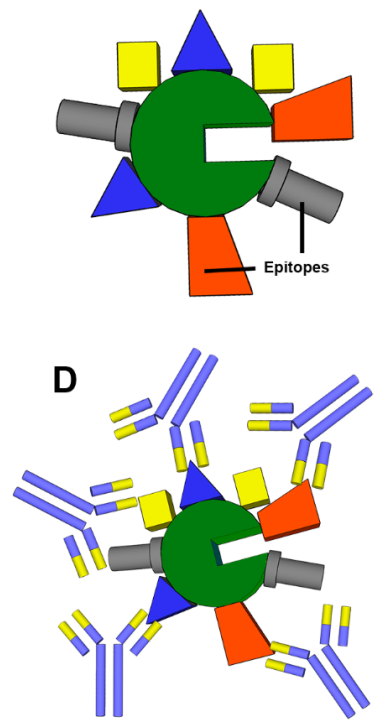

$\mathbf{E}$
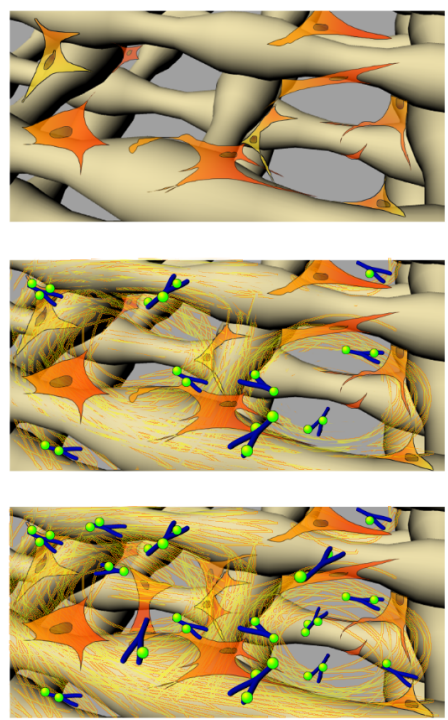

Figure 9.1: A schematic representation of an immunoglobulin $G(\operatorname{Ig} G)$ antibody. $\operatorname{Ig} G$ is a single protein made from four peptides joined by disulfide bonds (A). There is a single constant region containing the $\mathrm{Fc}$ portion and species-specific antigens. The variable region contains the Fab portion that binds the epitope portion of the antigen (B). Monoclonal antibodies react with a specific epitope of an antigen $(\mathrm{C})$ while polyclonal antibodies react with various epitopes (D). Fluorescent labeled Abs can enable the localization of specific biological components within 3D tissue engineering constructs over time (E, from top to bottom increasing in culture time). Figures are not to scale.

form, cartilage has an extremely high matrix/cell ratio: only $2-3 \%$ of its mass consists of chondrocytes which are the only cell type residing in cartilage tissue [8].

Cartilage ECM is rich in collagen (12-21\%), proteoglycans (6-10\%) and water (65$80 \%$ ). The main function of collagen fibrils is to give structure and tensile strength to the cartilage. The 3D orientation of collagen fibrils enables the immobilization of highly hydrated negatively charged proteoglycans [6]. Depending on the zone and function within the cartilage, the fibers can be oriented horizontally on the surface to absorb shear forces, or in an arch-like orientation and more vertical orientation in deeper zones to transduce mechanical forces throughout the entire tissue. This also reflects a different content of collagen, proteoglycans and water when moving from the superficial to the middle and deep zones [9]. The main type of collagen in hyaline cartilage is collagen type-II (90\%), yet small amounts of other types can be detected.

Proteoglycans can be divided in two main classes: non-aggregating and aggregating. Small non-aggregating proteoglycans consist of a core protein to which a large number of sulfated glycosaminoglycans (GAGs) are attached. These non-aggregating proteoglycans can bind to hyaluronic acid, which also binds to chondrocytes. GAGs mostly found in hyaline articular cartilage are keratin sulfate, chondroitin sulfate and 
dermatan sulfate [10]. Although promising results such as increased proteoglycan production and up-regulation of chondrogenic markers have been obtained in scaffoldbased cartilage tissue engineering, the regeneration of functional cartilage remains a challenge. In vitro produced ECM mainly shows the presence of collagen type-I with a lack of collagen-fiber organization, resulting in fibrous cartilage-like matrix with poor mechanical properties. Efforts have been made to enhance ECM production with mechanical stimuli, yet no single study showed cartilage regeneration in engineered tissue constructs with similar ECM composition, mechanical properties and structure as found in native cartilage [11].

Bone consists for $60 \%$ of minerals, $30 \%$ of organic components and $10 \%$ of water and its main function is to provide mechanical support to the body. It also protects vital organs, provides attachment site for ligaments and tendons, and encloses the bone marrow, which is the main breeding place for white and red blood cells, and other mononuclear cell types such as hematopoietic stem cells. Furthermore, due to its high mineral content, mainly calcium and phosphate, it plays an important role in the regulation of calcium and phosphate levels in the blood [12].

The characteristic cell type that resides inside lacunae found in mineralized bone matrix is the osteocyte. Osteoblasts are present where new bone is formed. When incorporated in the lacunae, these cells become osteocytes. Osteoblasts originate from osteoprogenitor cells that reside in the bone-surface-lining membranes (periosteum and endosteum) and the bone marrow stroma. While osteoblasts are responsible for producing the ECM components forming bone, osteoclasts - the third and last type of bone cells present in bony tissues - are responsible to cleave and degrade ECM. This interplay between osteoblasts and osteoclasts is responsible of the exquisite homeostasis that keeps bone tissue to be continuously and dynamically changed in time. The organic phase of the bone mainly consists of fibril-forming collagens $(\sim 80 \%-$ $90 \%)$. Collagen type-I $(>95 \%)$ is the principal collagen in mineralized bone, and together with collagen type-V $(<5 \%)$, forms heterotypic fiber bundles that provide the basic structural integrity of connective tissues [13]. These fiber bundles are supported by various non-collagenous proteins which are dispersed between the collagen fibrils. The proteins in bone ECM have shown to be useful osteogenic markers, especially for the later stages of differentiation [14, 15]. Some non-collagenous bone specific matrix proteins are osteocalcin, osteopontin [16, 17], bone sialoprotein [18], osteonectin and proteoglycans such as biglycan and decorin [19]. The inorganic phase consists of deposited osteoids which are mineralized by the incorporation of hydroxyapatite crystals mainly consisting of calcium and phosphate. The combination of the organic and inorganic phase provides bone with both its mechanical strength and elastic properties.

In bone tissue engineering, the emphasis in scaffold development has been on optimal mechanical properties, biodegradability and architecture for cell colonization and organization, to ensure the integration of the scaffold with the host tissue [20]. The evaluation of a wide-range of materials for bone tissue engineering has revealed information about osteoblast adhesion and proliferation, osteo-induction, osteo-conduction, and ECM formation within engineered scaffolds. Still, despite efforts of researchers to mimic the physical and biochemical properties of native bone ECM, no control over high-order structures and biological functions of the produced 
ECM can be guaranteed with the currently available technologies. To date, to evaluate the exact composition and architecture of engineered ECM, histological analysis are still most commonly applied.

\subsection{Antibodies}

Antibodies (Abs) are proteins belonging to the immunoglobulin group and one of the most important defense mechanisms in vertebrate animals. In research, they are used as highly specific probes in order to identify and locate intra- and extracellular proteins, differentiate cell types and separate proteins. There are five major classes of immunoglobulins: immunoglobulin $\mathrm{G}(\mathrm{IgG}), \operatorname{Ig} \mathrm{A}$, $\operatorname{IgM}, \operatorname{IgD}$, and $\operatorname{IgE}$, listed in order of decreasing quantity found in plasma. Of these five classes, IgG is by far the most frequently used [21]. Immunoglobulins are made from two identical heavy chains $(\mathrm{H}$, $55-70 \mathrm{kDa}$, either $\kappa$ or $\lambda$ ) and two identical light chains (L, 24-25 kDa, either $\gamma, \epsilon$, $\delta, \alpha$, or $\mu$ ) peptides joined by disulfide bonds (Figure 9.1A). Pepsin cleaves the $\gamma$ chains on the $\mathrm{C}$-terminal side of disulfide bridges, resulting in one bivalent antigen fragment, $\mathrm{F}\left(\mathrm{ab}{ }^{\prime}\right) 2$. The enzyme, papain, can digest the hinge regions of the IgG molecule, thus, producing two antigen-binding fragments (Fab) and one crystalline fragment $(\mathrm{Fc})$. The constant region contains the Fc portion that binds to an Fc receptor, and is unique to the animal species in which the antibody was generated. The variable region contains the Fab portion that binds the epitope portion of the antigen, and therewith gives Abs their specificity. However, recent studies and analyses of the growing number of available Abs indicated that this separation between the two functional regions may be an oversimplification [22].

A single antigen has multiple epitopes (Figure 9.1B) to allow Abs to recognize it. Monoclonal antibodies are a homogeneous population of immunoglobulins generated by a B-cell clone to a single epitope on the antigen (Figure 9.1C). A heterogeneous mixture of antibodies is known as polyclonal antibodies (Figure 9.1D). These antibodies are immunochemically dissimilar, having slightly different specificities and affinities. Polyclonal antibodies are usually produced in rabbits due to the ease of breeding of these animals. A possible application of Ab-based ECM detection in 3D tissue engineered scaffolds is schematically presented in Figure 9.1E. Initially, only cells are present in the in vitro culture (upper figure). Over time, the cells will start to secrete specific ECM components such as collagen type-I to which a targeted label will bind. With increasing concentration of ECM components, the binding of labeled Abs will also increase, resulting in a higher overall brightness of the substrate upon optical detection.

\subsection{Antibody conjugation chemistry}

The direct conjugation of antibodies to detectable labels or agents allows the combination of the label properties with the high specificity and selectivity of antibodies [23]. Three main label types can be distinguished: fluorescent [24-27], enzymatic [28, 29], and particulate [21, 30]. Fluorescent immuno-labels enable the detection of specific components qualitatively and quantitatively by detecting light emitted from a 
fluorophore with a different wavelength than the light used to excite the fluorophore [21]. The function of enzymatic-labels is based on the conversion of an uncolored water-soluble substrate to a colored water-insoluble product. A well-known enzyme for this type of immuno-assay is horse radish peroxidase (HRP). Antibody conjugated particles were developed already decades ago for the immunolabeling of specific ECM components in scanning electron microscopy (SEM) analysis, although required sample processing made real-time monitoring impossible [31]. To date, particle based labels comprise a wide range of materials from heavy metals such as colloidal gold or small gold particles [30, 32, 33] to magnetic beads [34-36], radioactive components $[25,37,38]$ and combinations of, for example, microbeads and covalently bound or entrapped fluorescent moieties [39].

Similar as for proteins, the reactivity of an antibody is determined by its amino acid composition and tertiary structure [40]. Understanding the functional groups available on an antibody is vital for finding the most appropriated conjugation method. Most Ab labelling strategies use one of the three types of available reactive groups. These groups comprise primary amines $\left(-\mathrm{NH}_{2}\right)$, sulfhydryl groups (-SH) and carbohydrates (sugars) [41, 42]. Primary amines are the most commonly used groups for conjugation, since they are abundant, widely distributed and easily modified due to their reactivity and location on the surface of the antibody [43]. Nhydroxysuccinimidyl ester (NHS ester) reactive group is the most specific and efficient reagent to target primary amines [43]. The only drawback of this strategy is that it may cause a significant decrease in the antigen-binding activity of the antibody [44]. This is due to the presence of primary amines in the binding site, which can also be modified. Moreover, lysines, on which primary amines can be found, have a positive net charge while fluorophores have a negative net charge, which may alter antibody conformation and activity upon conjugation. This decrease in activity is particularly noticeable when working with monoclonal antibodies or when attempting to achieve a higher degree of labelling (DOL) [40]. The second useful target for covalently labelling antibodies is via sulfhydryls. Disulfide bonds are important in antibody function as they contribute to the tertiary structure, covalently connecting heavy and light chains and connecting the two Ab halves at the hinge region. Conjugation at sulfur atoms requires that the thiols to which the label will be bound contains free sulfhydryl group. Because disulfides in the hinge region are the most susceptible to reduction, a commonly utilized method to cleave these disulfides bridges is by introducing papain [40]. Papain induced cleavage splits the antibody into monovalent halves without changing the antigen-binding site. Labelling Abs at hinge-region sulfhydryls ensures consistent labelling at a defined location and degree. The third useful target for labelling nanoparticles with antibodies is carbohydrate moieties [40]. Since glycosylation sites are found on the Fc portion of the Ab, they can often be modified without affecting the antigen-binding capacity. Labelling carbohydrates requires more steps than labelling amines because carbohydrates must first be oxidized to obtain reactive aldehydes. Aldehyde-activated (-CHO) sugars can react directly to primary amines or to reagents that have been activated with hydrazide groups. Recently, Shrestha et al. performed an extensive study on the application of the three previously mentioned conjugation methods to conjugate a specific antibody to one type of fluorophore [40]. They concluded that amine based conjugation was by far the best technique due to 
its simplicity, rapidity, ease of operation, higher conjugate yield and lower costs.

To enable the direct coupling of a label to the antibody via $-\mathrm{NH}_{2},-\mathrm{SH}$ or $-\mathrm{CHO}$ groups to form a detectable antibody, functionalization of the label and or antibody is required. Several well-known strategies to couple a label covalently to the reactive groups of the antibody are, via maleimide activation, active ester formation and biotin-avidin or biotin-streptavidin coupling [45, 46]. Furthermore, non-covalently coupling methods have been developed via hydrophobic interactions, electrostatic association with the particles coating, ligand coordination such as thiols and histidines and nickel mediated assembly of histidine to carboxyl groups.

The aim of this study was to develop a protocol for the conjugation of bone and cartilage specific Abs to be able to monitor ECM formation in 3D tissue engineered constructs. The probes have been developed considering that they should provide enhanced contrast in imaging modalities such as MRI, micro-CT or nuclear imaging for which transparency of the construct does not form an issue. Therefore, the conjugation chemistry should be compatible with particles that could be applied as contrast agents. Here, we chose to optimize and test anti-collagen-I and anti-collagenII Abs conjugated with fluorescent probes as a proof of concept. We have validated the binding specificity with collagen type-I and collagen type-II on collagen type-I coated glass slides, native cartilage and bone tissue sections and on 3D tissue engineered constructs. We show that our conjugation protocol provides a sufficient DOL retaining an adequate antibody-antigen binding affinity to detect ECM components.

\subsection{Materials and Methods}

\subsubsection{Ab-dye conjugation procedure}

Anti-collagen type-I N-Terminal and anti-collagen type-II N-terminal (both polyclonal, produced in rabbit, Sigma-Aldrich), the dyes ATTO 488 NHS ester (SigmaAldrich) and ATTO 594 NHS ester (Sigma-Aldrich) and Zeba ${ }^{\text {TM}}$ Spin Desalting Columns (7K MWCO, $0.5 \mathrm{~mL}$, Thermo Scientific) were used. Prior to use, the buffer in the columns was exchanged to PBS with $0.02 \mathrm{M}$ sodium azide according to manufacture's instruction. Sodium azide was used as a preservative to inhibit the growth of contaminants such as bacteria or fungi in the antibody solutions.

Before the conjugation step, $50 \mu \mathrm{L}$ of antibody solution was passed through the column once in order to exchange the antibody buffer solution to phosphate buffered saline (PBS) solution and collected in an amber colored $1.5 \mathrm{~mL}$ eppendorf tube. To adjust the $\mathrm{pH}$ to the optimal conjugation value $(\mathrm{pH}=8.3), 3 \mu \mathrm{L}$ of $1 \mathrm{M}$ sodium bicarbonate $(\mathrm{pH}=8.3)$ were added to the antibody solution. On the first use, the dye was dissolved to $2 \mathrm{mg} / \mathrm{mL}$ in anhydrous DMSO according to manufacture's instruction, aliquoted and stored at $-20{ }^{\circ} \mathrm{C}$ for further experiments. In order to obtain the desired DOL between 2 and 3 labels per antibody, approximately $1.5 \mu \mathrm{L}$ of dye solution were added to the antibody solution, mixed and incubated for 1 hour at RT with continuous stirring. The conjugates solution was then passed through the desalting columns three times to remove any unconjugated dye. An ND1000 spectrophotometer (Nanodrop Technologies, USA) was utilized to analyze the obtained concentration 
and ensure that the reaction occurred as expected. If required, BSA was added to increase the solution concentration above $1 \mathrm{mg} / \mathrm{mL}$.

The anti-collagen type-I conjugated ATTO 488 dye will further be referred to as anti-col-I. The anti-collagen type-II conjugated ATTO 594 dye will further be referred to as anti-col-II. The conjugate solution was stored at $4{ }^{\circ} \mathrm{C}$. To validate our label, a validated anti-collagen type-I antibody (ab292, Abcam, Cambridge, UK) and a secondary anti-rabbit antibody conjugated to an Alexa-Fluor 488 fluorophore were used in several experiments as a positive control and will be further referred to as control probe.

\subsubsection{Conjugate characterization}

The efficiency of the procedure and DOL of the antibody-dye conjugate were determined with an ND1000 spectrophotometer (Nanodrop Technologies, USA). The equations applied to calculate the protein concentration and DOL can be found in the supplementary information. SDS-PAGE was applied to get an impression of the purity of the conjugate. The gel was run at $70 \mathrm{~V}$ for stacking and then shifted to 30 $\mathrm{mA}$ until separation was completed.

\subsubsection{Scaffold fabrication}

Scaffolds were fabricated from 300PEOT55PBT45 (300/55/45) (PolyVation, The Netherlands), a block copolymer composed of poly(ethylene oxide terephthalate) (PEOT) and poly(butylene terephthalate) (PBT) with a weight ratio of 55 to 45 for the two components, respectively, and a molecular weight of the starting poly(ethylene glycol) (PEG) segments of 300 Da used in the co-polymerization process.

For electrospun (ES) scaffolds, a $28 \%$ (w/v) solution of 300/55/45 was prepared in a mixture of chloroform (CHCl3)-1, 1, 1, 3, 3, 3-hexafluoro-2-propanol (HFIP) with a ratio of $78-22 \% \mathrm{v} / \mathrm{v}$. The solution was left stirring at room temperature overnight. Subsequently, the solution was loaded into a syringe and pumped at a controlled flow rate using a syringe pump (KDS 100, KD Scientific). PTFE tubing was used to connect the syringe and a needle to which a high voltage was applied (Gamma High Voltage Research Inc., FL, USA). A stainless steel collector, covered by an aluminum foil, was used to collect the ES scaffold. A voltage of $12 \mathrm{kV}$ was applied to a $1.2 \mathrm{~mm}$ needle, which was placed at a distance of $25 \mathrm{~cm}$ from the collector. The flow rate was set at $15 \mathrm{~mL} /$ hour, temperature to $25{ }^{\circ} \mathrm{C}$, and humidity to $30 \%$. Upon reaching a sheet thickness of approximately $200 \mu \mathrm{m}$ the electrospinning process was stopped and disks with a diameter of $15 \mathrm{~mm}$ were punched out from the sheet.

Fused deposition modeling was used to fabricate 3D scaffolds with a bioscaffolder (SysENG, Germany), as described before [47]. The cylindrical shaped scaffolds had diameter of $8 \mathrm{~mm}$, a height of $3 \mathrm{~mm}$, a fiber-to-fiber distance of $1000 \mu \mathrm{m}$, a fiber diameter of approximately $200 \mu \mathrm{m}$, and a layer thickness of $150 \mu \mathrm{m}$.

\subsubsection{Cell culture}

Bone marrow aspirates were obtained from donors after written informed consent and human bone marrow stromal cells (hMSCs) were isolated and proliferated as previ- 
ously described [48]. In short, 20-gauge needles were used to re-suspend the aspirates which were then plated at a density of $5 \times 10^{5}$ cells $/ \mathrm{cm}^{2}$. Cells were cultured in hMSC proliferation medium, for which the composition is described in the supplementary data, at $37{ }^{\circ} \mathrm{C}$ in a humid atmosphere with $5 \% \mathrm{CO}_{2}$. The culture medium was refreshed three times a week. After monolayer expansion, cells were either cryopreserved or used for further subculturing.

Passage $3 \mathrm{hMSCs}$ were detached from the culture flasks by trypsinization upon reaching $70 \%$ confluence. All scaffolds were sterilized by immersion in $70 \%$ ethanol for at least 2 hours, washed multiple times with sterile PBS and subsequently placed into a non-treated 24 well plate (NUNC). The constructs were then incubated at $37{ }^{\circ} \mathrm{C}$ in a humid atmosphere with $5 \% \mathrm{CO}_{2}$ overnight in basic medium to pre-wet them. To prevent the ES scaffold discs from floating, rubber O-rings (Eriks BV, The Netherlands) were used to hold the discs in place. After incubation, the medium on the scaffold was aspirated and 75,000 cells and 250,000 cells were seeded onto each electrospun scaffold and plotted scaffolds, respectively. After 7 days of culture in proliferation medium, the media was replaced with chondrogenic and osteogenic medium in order to start differentiation. All media compositions are described in the supplementary information.

\subsubsection{Immunostaining}

After 14 days of culture, the samples were washed once with PBS, fixed with paraformaldehyde (4\% in PBS) for half an hour and stored in PBS at $5{ }^{\circ} \mathrm{C}$. Prior to $\mathrm{Ab}$ incubation, constructs were blocked with a buffer $(0.5 \%$ Triton $\mathrm{X}-100,1 \%$ BSA in PBS). Samples were incubated with the fluorescently conjugated primary Abs, at $4{ }^{\circ} \mathrm{C}$ overnight. After incubation, constructs were washed three times with PBS for 5 minutes each. Cell nuclei labelling was performed with 4',6' Diamidin-2'phenylindoldihydrochlorid (DAPI, $100 \mathrm{ng} / \mathrm{mL}$ in PBS, Sigma, Munich, Germany) and actin filaments were stained with Phalloidin to visualize the cytoskeleton. Samples were imaged using a Nikon A1 confocal microscope (Nikon Instruments Inc.). 


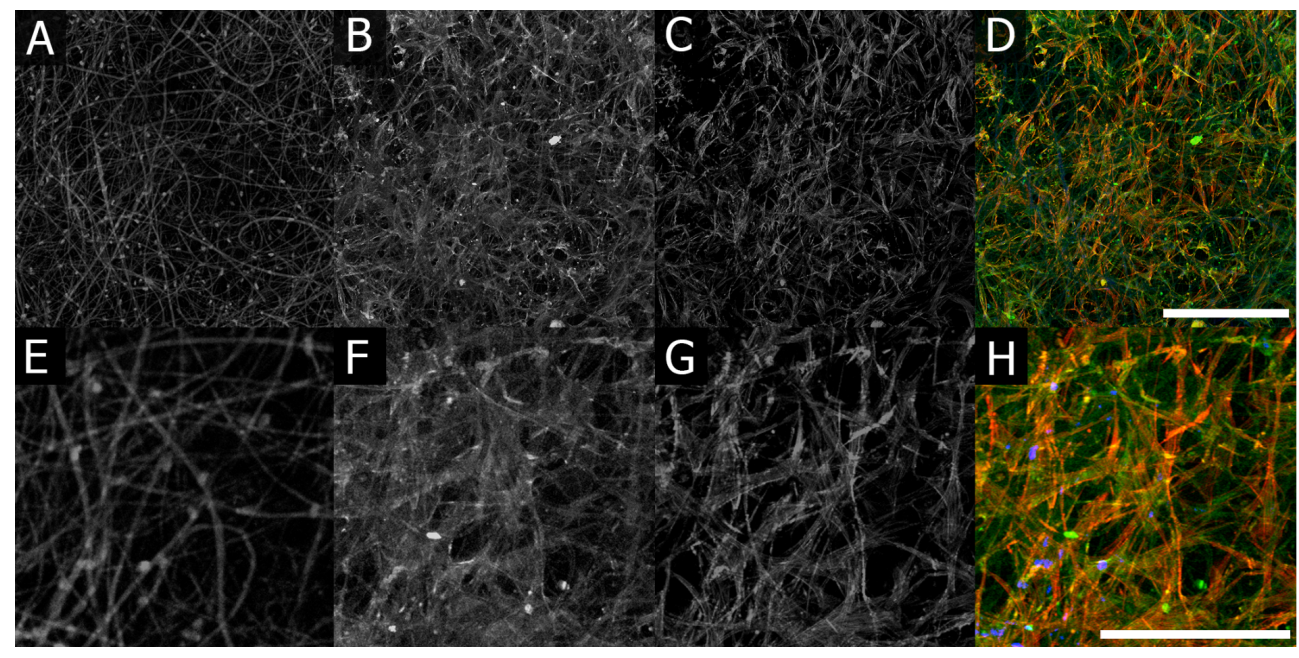

Figure 9.2: Electrospun scaffolds seeded with hMSCs after 14 days of culture in osteogenic medium. (A, E) A DAPI staining is applied to identify the nuclei of the cells. In this channel autofluorescence of the polymer enables to localize the scaffolds' fibers. (B, F) Anti-Col-I shows a homogeneous distribution over the scaffold's surface. (C, G) Actin filaments are stained with Phalloidin. (D, H) An overlaid representation of the three stainings shows nuclei in blue, collagen type-I in green and actin in red. Images $\mathrm{E}-\mathrm{H}$ represents digital magnifications of images A-D. Scale bar represents (A-D) $1 \mathrm{~mm}$ and (E-H) $500 \mu \mathrm{m}$.

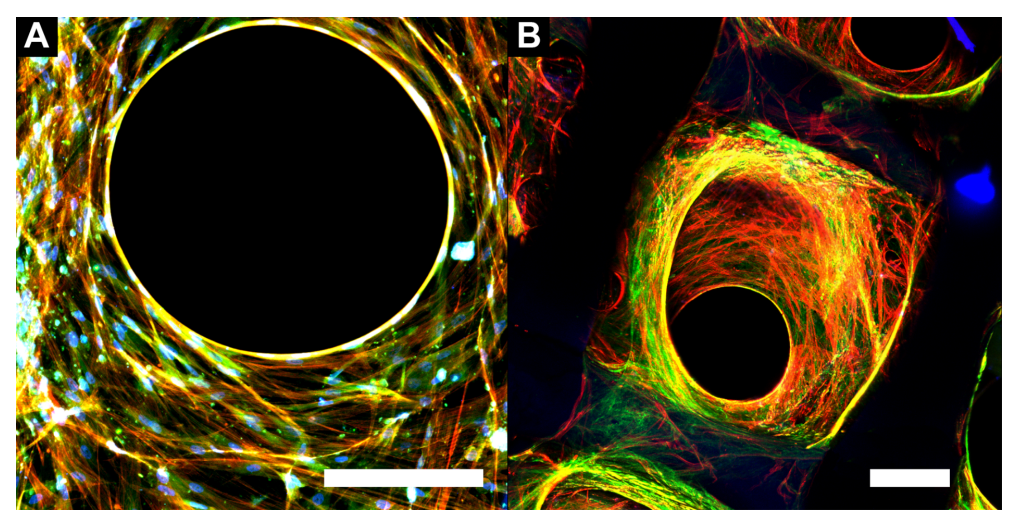

Figure 9.3: Bioplotted scaffolds seeded with hMSCs after 14 days of culture in osteogenic medium. The samples were stained with DAPI (blue) to visualize the nuclei, with Phalloidin (red) to visualize actin filaments and with (A) anti-col-I or (B) the control probe (both green). Scale bars represent $200 \mu \mathrm{m}$. 


\subsection{Results and Discussion}

\subsubsection{Ab and dye concentration by nanodrop}

To quantify the DOL after conjugation of the fluorescent probe to the Ab, the absorbance spectrum was analyzed with an ND1000 spectrophotometer (Nanodrop Technologies, USA). Detailed calculations to determine the concentrations of the Abs and dye, and their ratio representing the DOL can be found in the results section of the supplementary information. The concentrations of the conjugated antibodies after purification were found to be 0.13 and $0.125 \mathrm{mg} / \mathrm{ml}$ for anti-col-I and anti-colII, respectively. The DOL was determined at an average of 7 ATTO 488 and of 5.6 ATTO 594 fluorophores per antibody for anti-col-I and anti-col-II, respectively.

SDS-PAGE was performed before adding BSA to the conjugate solution to get insight in the purity of the probe solution (Figure S9.1). In both antibody conjugated dyes, a strong fluorescent band was observed in the top of the gel, where higher molecular weight $\left(\mathrm{M}_{W}\right)$ molecules were retained. Two other bands were observed at lower $\mathrm{M}_{W}$, however, these bands seemed significantly weaker compared to the ones in the top layer of the gel. The probe solution was therefore considered sufficiently purified with just low amounts of unconjugated label and Abs.

\subsubsection{Cell culture}

The ultimate goal of the probe developed here was to be applied on culture systems to monitor and characterize tissue formation in 3D scaffolds in vitro. Firstly, the antigen affinity of the anti-col-I was assessed on a pure collagen type-I coating (Rat) and compared to the affinity of the commercially available control probe (Figure S9.2). It was observed that both probes showed high binding affinity with the collagen type-I coating whereas no label was detected on the surface of the glass slide. In anti-col-I some fluorescent aggregates were observed. This could have been caused by preaggregation of both the Abs and the fluorophores prior to conjugation. Anti-col-I was further tested on a histological section of demineralized rat tail tissue to get insights in non-specific binding (Figure S9.3). The anti-col-I probe was applied on hMSCs cultured for 14 days in osteogenic medium on electrospun scaffolds (Figure 9.2). These scaffolds showed randomly oriented fibers with a non-uniformly distributed average diameter of $3.06 \pm 1.95 \mu \mathrm{m}$, with a minimum diameter of approximately $1 \mu \mathrm{m}$ and maximum fiber diameter of $8 \mu \mathrm{m}$.

From Figure 9.2, it can be observed that collagen type-I was found intra-cellularly between the actin filaments and inter-cellularly between multiple cells. Collagen typeI staining was homogeneously distributed over the cells and the fibers of the scaffold. A difference between chondrogenic and osteogenic samples could be observed (Figure S9.4). Chondrogenic samples showed a higher confluence of the scaffolds and relatively high amounts of collagen type-I staining from both the control and the anti-col-I probes. In osteogenic medium the collagen type-I staining seemed to be more defined causing less blurred background signal than observed on chondrogenic samples. In osteogenic medium the control probe showed an inhomogeneous distribution of highly fluorescent domains which were much brighter than the fluorescence detected from the anti-col-I probe. 
Anti-col-II (red in Figure S9.4C and 9.4F) did not provide sufficient staining in both chondrogenic and osteogenic medium to monitor any collagen type-II production. Just a few red spots were observed in both chondrogenic and osteogenic samples. This could be due to a low amount of collagen type-II production in the 2 weeks of culture, but we cannot exclude that this absence of detectable signal could be caused by a relatively low binding affinity of the Ab itself or by a decreased binding affinity of the Ab after label conjugation. The red spots could be caused by impurities in the sample or the dye solution as observed also for anti-col-I on the collagen type-I coated glassslides (Figure S9.2A). Since, the anti-col-II showed no specific binding affinity with both the tissue on electrospun scaffolds and native tissue and due to the absence of a control probe for collagen type-II, the quality of the probe was not further assessed on the bioplotted scaffolds. However, we hypothesize that the conjugation procedure introduced here for anti-col-I could be easily translated to N-terminal anti-collagen type-II Abs.

Figure 9.3 shows stacked images retrieved by a flattening procedure on multiple confocal scans on bioplotted scaffolds seeded with hMSCs after 14 days of culture in osteogenic medium. The circular pattern formed by the seeded hMSCs has shown to be typical for tissue formation in this type of scaffolds, where cells initially attach on the struts of the scaffolds and over time close the pore. This pattern of tissue growth is one of the processes that can be considered important to assess during culture to monitor the type and morphology of the ECM that was produced.

From Figure 9.3, it could be seen that collagen type-I was found both with anticol-I and with the control probe. In both samples, the collagen type-I showed to be distributed over the areas where cells were located as well. Therefore, the anti-col-I probe can be considered successfully developed and applied. The high DOL obtained in this study could have interfered with the binding affinity of the Ab to the antigen, which could explain the lower brightness of the anti-col-I compared to the control probe. The stability of the label was not expected to result in this lower brightness, since the ATTO-dyes applied in anti-col-I and anti-col-II, are generally more stable than the fluorophore coupled to the control probe.

In theory, the conjugation chemistry applied on this Ab allows for the coupling to any other kind of labeling particle. Applying other imaging modalities would permit imaging of collagen type-I at greater depths without the need to stain the cells and nuclei. By coupling collagen type detection to a responsive scaffold material, for example a sort of actuating system to locally administer certain stimuli, more control over collagen production and collagen orientation could be realized. One can think of a direct or indirect actuating system that enables to locally apply strain, which is often suggested as a key culture parameter for collagen orientation and therewith ECM functionality.

\subsection{Conclusion}

The main objective of this study was the optimization and validation of a method that could be used to functionalize particles and fluorophores to be applied in several imaging modalities. Based on a concise review on Abs and available conjugation strategies, the most promising method for our application was chosen and optimized. 
Both anti-collagen type-I and anti-collagen type-II Abs were successfully conjugated to their respective dyes. The anti-col-I probe showed a similar selectivity to a control probe targeting collagen type-I in all tests performed. Despite the promising preliminary results obtained with the anti-col-I probe, further optimization to improve the antigen binding activity of both probes will be required for successful multiplexed images. Yet, from the successful collagen type-I detection with anti-col-I, we conclude that the conjugation via amines offers an easy and feasible chemistry to obtain specific anti-collagen-I Abs coupled to several types of fluorophores and particles.

\section{Acknowledgement}

The authors gratefully acknowledge the funding from the Netherlands Institute for Regenerative Medicine (NIRM) through the grant number FES0908. 


\section{References}

[1] Appel AA, Anastasio MA, Larson JC, Brey EM. Imaging challenges in biomaterials and tissue engineering. Biomaterials. 2013;34:6615-30.

[2] Washburn NR, Weir M, Anderson P, Potter K. Bone formation in polymeric scaffolds evaluated by proton magnetic resonance microscopy and X-ray microtomography. Journal of Biomedical Materials Research Part A. 2004;69A:738-47.

[3] Chesnick IE, Avallone FA, Leapman RD, Landis WJ, Eidelman N, Potter K. Evaluation of bioreactor-cultivated bone by magnetic resonance microscopy and FTIR micro spectroscopy. Bone. 2007;40:904-12.

[4] Alves da Silva ML, Crawford A, Mundy JM, Correlo VM, Sol P, Bhattacharya M, et al. Chitosan/polyester-based scaffolds for cartilage tissue engineering: assessment of extracellular matrix formation. Acta biomaterialia. 2010;6:1149-57.

[5] Roos H, Adalberth T, Dahlberg L, Lohmander LS. Osteoarthritis of the knee after injury to the anterior cruciate ligament or meniscus: the influence of time and age. Osteoarthritis Cartilage. 1995;3:261-7.

[6] Riesle J, Hollander AP, Langer R, Freed LE, Vunjak-Novakovic G. Collagen in tissue-engineered cartilage: types, structure, and crosslinks. J Cell Biochem. 1998;71:313-27.

[7] Kuettner KE. Biochemistry of articular cartilage in health and disease. Clinical biochemistry. 1992;25:155-63.

[8] Moreira-Teixeira LS, Georgi N, Leijten J, Wu L, Karperien M. Cartilage tissue engineering. Endocrine development. 2011;21:102-15.

[9] Klein TJ, Sah RL. Modulation of depth-dependent properties in tissue-engineered cartilage with a semi-permeable membrane and perfusion: a continuum model of matrix metabolism and transport. Biomechanics and modeling in mechanobiology. 2007;6:21-32.

[10] Van Blitterswijk C. Tissue Engineering. Academic Press, Elsevier; 2008. ISBN: 978-0-12-3708694

[11] Zhang L, Hu J, Athanasiou KA. The role of tissue engineering in articular cartilage repair and regeneration. Critical reviews in biomedical engineering. 2009;37:1-57.

[12] Zaidi M. Skeletal remodeling in health and disease. Nature medicine. 2007;13:791-801.

[13] Chiquet M. Regulation of extracellular matrix gene expression by mechanical stress. Matrix biology : journal of the International Society for Matrix Biology. 1999;18:417-26.

[14] Lian JB, Stein GS. Concepts of osteoblast growth and differentiation: basis for modulation of bone cell development and tissue formation. Critical reviews in oral biology and medicine : an official publication of the American Association of Oral Biologists. 1992;3:269-305.

[15] Yao KL, Todescan R, Jr., Sodek J. Temporal changes in matrix protein synthesis and mRNA expression during mineralized tissue formation by adult rat bone marrow cells in culture. Journal of bone and mineral research : the official journal of the American Society for Bone and Mineral Research. 1994;9:231-40.

[16] Sodek J, Ganss B, McKee MD. Osteopontin. Critical reviews in oral biology and medicine : an official publication of the American Association of Oral Biologists. 2000;11:279-303.

[17] McKee MD, Nanci A. Osteopontin: an interfacial extracellular matrix protein in mineralized tissues. Connect Tissue Res. 1996;35:197-205.

[18] Ganss B, Kim RH, Sodek J. Bone sialoprotein. Critical reviews in oral biology and medicine : an official publication of the American Association of Oral Biologists. 1999;10:79-98.

[19] Sodek J. CS. Molecular Regulation of Osteogenesis. In: J.E. D, editor. Bone Engineering. Toronto: Em Squared incorporated; 2000.

[20] Ferreira AM, Gentile P, Chiono V, Ciardelli G. Collagen for bone tissue regeneration. Acta biomaterialia. 2012;8:3191-200.

[21] Burry RW. Controls for immunocytochemistry: an update. The journal of histochemistry and cytochemistry : official journal of the Histochemistry Society. 2011;59:6-12. 
[22] Sela-Culang I, Kunik V, Ofran Y. The Structural Basis of Antibody-Antigen Recognition. Frontiers in immunology. 2013;4:302.

[23] Ansell SM, Harasym TO, Tardi PG, Buchkowsky SS, Bally MB, Cullis PR. Antibody conjugation methods for active targeting of liposomes. Methods in molecular medicine. 2000;25:51-68.

[24] Asti A, Visai L, Dorati R, Conti B, Saino E, Sbarra S, et al. Improved cell growth by BioOss/PLA scaffolds for use as a bone substitute. Technology and health care : official journal of the European Society for Engineering and Medicine. 2008;16:401-13.

[25] Hofer T, Skeffington LR, Chapman CM, Rader C. Molecularly defined antibody conjugation through a selenocysteine interface. Biochemistry. 2009;48:12047-57.

[26] Lichlyter DJ, Grant SA, Soykan O. Development of a novel FRET immunosensor technique. Biosens Bioelectron. 2003;19:219-26.

[27] Trier NH, Hansen PR, Houen G. Production and characterization of peptide antibodies. Methods. 2012;56:136-44.

[28] Shinomiya Y, Kato N, Imazawa M, Miyamoto K. Enzyme immunoassay of the myelin basic protein. Journal of neurochemistry. 1982;39:1291-6.

[29] King TP, Kochoumian L. A comparison of different enzyme-antibody conjugates for enzymelinked immunosorbent assay. J Immunol Methods. 1979;28:201-10.

[30] Liopo A, Conjusteau A, Tsyboulski D, Ermolinsky B, Kazansky A, Oraevsky A. Biocompatible Gold Nanorod Conjugates for Preclinical Biomedical Research. Journal of nanomedicine \& nanotechnology. 2012;S2.

[31] Singer SJ, Schick AF. The Properties of Specific Stains for Electron Microscopy Prepared by the Conjugation of Antibody Molecules with Ferritin. The Journal of biophysical and biochemical cytology. 1961;9:519-37.

[32] Karmani L, Labar D, Valembois V, Bouchat V, Nagaswaran PG, Bol A, et al. Antibodyfunctionalized nanoparticles for imaging cancer: influence of conjugation to gold nanoparticles on the biodistribution of 89Zr-labeled cetuximab in mice. Contrast Media Mol Imaging. 2013;8:402-8.

[33] Robinson JM, Takizawa T, Vandre DD, Burry RW. Ultrasmall immunogold particles: important probes for immunocytochemistry. Microscopy research and technique. 1998;42:13-23.

[34] Paik CH, Ebbert MA, Murphy PR, Lassman CR, Reba RC, Eckelman WC, et al. Factors influencing DTPA conjugation with antibodies by cyclic DTPA anhydride. J Nucl Med. 1983;24:1158-63.

[35] Shu CY, Ma XY, Zhang JF, Corwin FD, Sim JH, Zhang EY, et al. Conjugation of a watersoluble gadolinium endohedral fulleride with an antibody as a magnetic resonance imaging contrast agent. Bioconjugate chemistry. 2008;19:651-5.

[36] Rieger M, Schaumann GE, Mouvenchery YK, Niessner R, Seidel M, Baumann T. Development of antibody-labelled superparamagnetic nanoparticles for the visualisation of benzo[a]pyrene in porous media with magnetic resonance imaging. Analytical and bioanalytical chemistry. 2012;403:2529-40.

[37] Zhang Y, Hong H, Engle JW, Bean J, Yang Y, Leigh BR, et al. Positron emission tomography imaging of CD105 expression with a $64 \mathrm{Cu}$-labeled monoclonal antibody: NOTA is superior to DOTA. Plos One. 2011;6:e28005.

[38] Gupta S, Batra S, Jain M. Antibody labeling with radioiodine and radiometals. Methods Mol Biol. 2014;1141:147-57.

[39] Theilacker N, Roller EE, Barbee KD, Franzreb M, Huang X. Multiplexed protein analysis using encoded antibody-conjugated microbeads. J R Soc Interface. 2011;8:1104-13.

[40] Shrestha D, Bagosi A, Szollosi J, Jenei A. Comparative study of the three different fluorophore antibody conjugation strategies. Analytical and bioanalytical chemistry. 2012;404:1449-63.

[41] Acchione M, Kwon H, Jochheim CM, Atkins WM. Impact of linker and conjugation chemistry on antigen binding, Fc receptor binding and thermal stability of model antibody-drug conjugates. mAbs. 2012;4:362-72.

[42] Brinkley M. A Brief Survey of Methods for Preparing Protein Conjugates with Dyes, Haptens, and Cross-Linking Reagents. Bioconjugate chemistry. 1992;3:2-13.

[43] Dhar TK, Dasgupta S, Ray D, Banerjee M. A filtration method for rapid preparation of conju- 
gates for immunoassay. J Immunol Methods. 2012;385:71-8.

[44] Wilbur DS, Stray JE, Hamlin DK, Curtis DK, Vessella RL. Monoclonal-Antibody Fab' Fragment Cross-Linking Using Equilibrium Transfer Alkylation Reagents - a Strategy for Site-Specific Conjugation of Diagnostic and Therapeutic Agents with $\mathrm{F}\left(\mathrm{Ab}^{\prime}\right)(2)$ Fragments. Bioconjugate chemistry. 1994;5:220-35.

[45] Algar WR, Tavares AJ, Krull UJ. Beyond labels: a review of the application of quantum dots as integrated components of assays, bioprobes, and biosensors utilizing optical transduction. Analytica chimica acta. 2010;673:1-25.

[46] Lao UL, Mulchandani A, Chen W. Simple conjugation and purification of quantum dot-antibody complexes using a thermally responsive elastin-protein L scaffold as immunofluoresecent agents. J Am Chem Soc. 2006;128:14756-7.

[47] Moroni L, de Wijn JR, van Blitterswijk CA. Three-dimensional fiber-deposited PEOT/PBT copolymer scaffolds for tissue engineering: influence of porosity, molecular network mesh size, and swelling in aqueous media on dynamic mechanical properties. Journal of biomedical materials research. 2005;75:957-65.

[48] Both SK, Van der Muijsenberg AJC, Van Blitterswijk CA, De Boer J, De Bruijn JD. A rapid and efficient method for expansion of human mesenchymal stem cells. Tissue engineering. 2007;13:3-9. 


\section{Supplementary Data}

\section{Materials and Methods}

\section{Conjugate Characterization}

The concentration of the protein and the dye was determined using the LambertBeer law (Equation 1 and 2). Proteins have a maximum absorption at $280 \mathrm{~nm}$, thus, absorbance at this wavelength $\left(\mathrm{A}_{280}\right)$ is often used to determine their concentration in solution. However, fluorescent dyes also absorb at $280 \mathrm{~nm}$, hence, a correction factor (CF) has to be applied.

$$
[\text { Protein }]=\frac{A_{280}-\left(A_{\max } \times C F\right)}{\epsilon_{I g G} \times p}
$$

Where:

$\mathrm{A}_{280}$ : the absorbance at $280 \mathrm{~nm}$

$\mathrm{A}_{\max }$ : the absorbance at $\lambda_{\max }$

$\lambda_{\max }$ : the wavelength where the absorbance has its maximum

CF: correction factor which depends on the dye's spectral properties

$\mathrm{P}$ : path length $(1 \mathrm{~cm})$

$\epsilon_{I g G}$ : molar extinction coefficient $\left(\right.$ in $\mathrm{M}^{-1} \mathrm{~cm}^{-1}$ ) of the pure protein at $280 \mathrm{~nm}$

$$
[d y e]=\frac{A_{\max }}{\epsilon_{\max } \times p}
$$

Where:

$\epsilon_{\max }$ : molar extinction coefficient $\left(\right.$ in $\mathrm{M}^{-1} \mathrm{~cm}^{-1}$ ) of the dye at its absorbance maximum.

The DOL is represented by the ratio between the concentration of the dye and the concentration of the protein as given in Equation 3.

$$
[\text { DOL }]=\frac{[\text { dye }]}{[\text { Protein }]}
$$

\section{Culture media}

Basic medium contained $\alpha$-minimal essential medium (Life Technologies), 10\% heatinactivated fetal bovine serum (FBS, Lonza), $0.2 \mathrm{mM}$ ascorbic acid (Asap; Life Technologies), $2 \mathrm{mM}$ L-glutamine (Life Technologies), $100 \mathrm{U} / \mathrm{mL}$ penicillin (Life Technologies), $100 \mu \mathrm{g} / \mathrm{mL}$ streptomycin (Life Technologies). Proliferation medium consisted of basic medium supplemented with $1 \mathrm{ng} / \mathrm{mL}$ basic fibroblast growth factor (FGF) (Instruchemie). Osteogenic medium consisted of basic medium supplemented with 10 nM dexamethasone. Chondrogenic medium contains Dulbecco's modified essential medium (D-MEM) (Life Technologies) with $0.2 \mathrm{mM}$ ascorbic acid, $100 \mathrm{U} / \mathrm{mL}$ penicillin (Life Technologies), $100 \mu \mathrm{g} / \mathrm{mL}$ streptomycin (Life Technologies), $50 \mu \mathrm{g} / \mathrm{mL}$ 
ITS-premix, $100 \mu \mathrm{g} / \mathrm{mL}$ sodium pyruvate, $10 \mathrm{ng} / \mathrm{mL}$ TGF- $\beta 3$ and $1 \mu \mathrm{M}$ dexamethasone. TGF- $\beta 3$ and dexamethasone were freshly added every time that the media was changed during culture.

\section{Collagen coating}

Glass slides with a diameter of $18 \mathrm{~mm}$ were immersed in $10 \%$ acetic acid in ethanol for 30 minutes, followed by $100 \%$ ethanol rinses and dried in the oven at $50{ }^{\circ} \mathrm{C}$. Collagen type I from rat tail (BD Biosciences, Two Oak Park. Bedford, USA) was diluted from a stock concentration of $11.59 \mathrm{mg} / \mathrm{mL}$ to $2 \mathrm{mg} / \mathrm{mL}$ in a $0.02 \mathrm{M}$ acetic acid solution. Glass slides were placed in a non-treated 12 well plate (NUNC) and $250 \mu \mathrm{L}$ of collagen solution was added. After 1 hour incubation at $37{ }^{\circ} \mathrm{C}$, glass slides were washed three times with PBS to remove any remaining acetic acid. The presence of collagen coating was confirmed by picosirius red staining (Supplementary Figure $9.2 \mathrm{C})$.

\section{Native tissue}

A 6 weeks old post-mortem rat was kindly provided by the department of biomedical signals and systems (MIRA institute, University of Twente). Animal use was regulated by national laws on animal experiments after approval from a local ethical committee. The tail of the rat was isolated and immersed in $12.5 \% \mathrm{EDTA}, \mathrm{pH}=8$, for 5 weeks in order to decalcify the tissues. EDTA was changed three times a week. A series of increasing ethanol concentrations $(60 \%, 70 \%, 80 \%, 90 \%, 96 \%, 100 \% \times 2)$, 2 days per concentration, was used to dehydrate the tissue. Subsequently, the tissue was immersed in butanol overnight and in eosin for 1 hour to stain them with a pink color to be able to localize the sample after embedding. Specimens where embedded in paraffin for 5 days in a holder at $60{ }^{\circ} \mathrm{C}$. Paraffin was changed after 2 days to remove any traces of butanol. The sections were cut at room temperature with $5 \mu \mathrm{m}$ intervals.

\section{Results}

The protein concentration is determined following the Lamberts Beer law (Equation 1 ) and the DOL is determined following Equation 3. The CF equals the $\epsilon_{280}$ of the dye divided by the $\epsilon_{\max }$ of the dye. The CFs for ATTO 488 and for ATTO 594 were provided by the supplier and found to be 0.1 and 0.51 , respectively. The $\epsilon_{\max }$ for ATTO 488 and for ATTO 594 were also provided by the supplier and were 90,000 and $120,000 \mathrm{M}^{-1} \mathrm{~cm}^{-1}$, respectively. The molar extinction coefficient for the AB (IgG) was set at $210,000 \mathrm{M}^{-1} \mathrm{~cm}^{-1}$. The path length in all measurements was set at $1 \mathrm{~cm}$.

\section{Anti-Collagen type-I conjugated to ATTO 488}

$\mathrm{A}_{280}$ was found to be 0.203 , while $\mathrm{A}_{\max }$ was found to be 0.469 at approximately 500 $\mathrm{nm}$. With these values the protein concentration was determined according to Equation 1 and found to be $7.43 \times 10^{-7} \mathrm{M}$ The molecular weight of IgG is approximately $150 \mathrm{kDa}$, so the concentration of the conjugated Anti-col-I was approximately 0.13 
$\mathrm{mg} / \mathrm{mL}$. Subsequently, the DOL was determined according to Equation 3 and found to be 7.01 .

\section{Anti-Collagen type-II conjugated to ATTO 594}

$\mathrm{A}_{280}$ was found to be 0.358 , while $\mathrm{A}_{\max }$ was found to be 0.435 at approximately 500 $\mathrm{nm}$. With these values the protein concentration was determined according to Equation 1 and found to be $6.48 \times 10^{-7} \mathrm{M}$ The molecular weight of IgG was approximately $150 \mathrm{kDa}$, so the concentration of the conjugated Anti-col-II was approximately 0.125 $\mathrm{mg} / \mathrm{mL}$. Subsequently, the DOL was determined according to Equation 3 and found to be 5.59 .

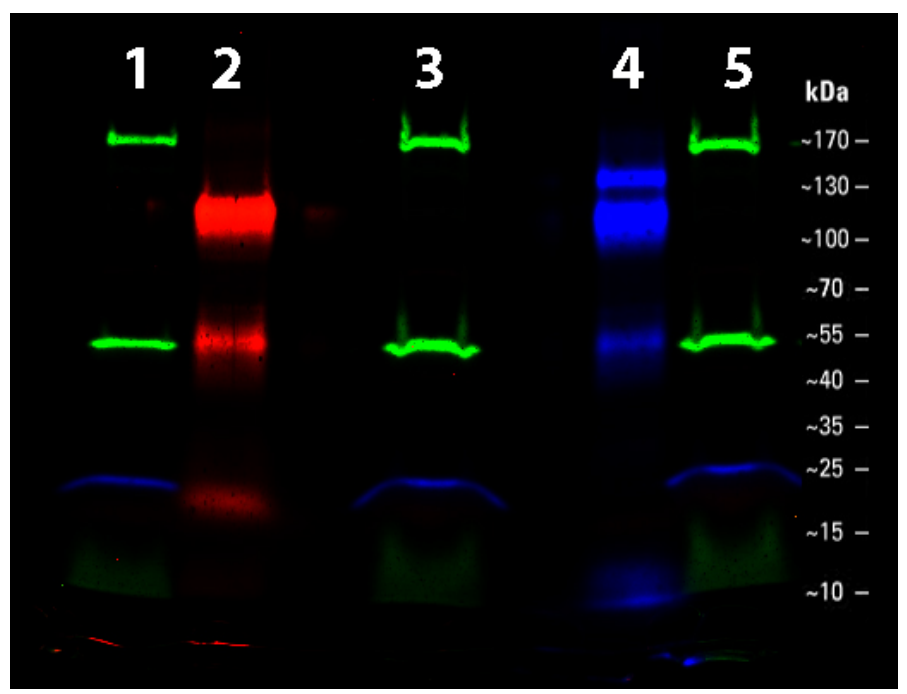

Figure S9.1. SDS page was run for anti-col-I and anti-col-II conjugates. The ladders were placed in the first (1), third (3) and fifth (5) lane and their fluorescent bands are displayed in green. Anti-col-II was located on the second column (2) and is displayed in red. Anti-col-I was located in the fourth column and is displayed in blue. 


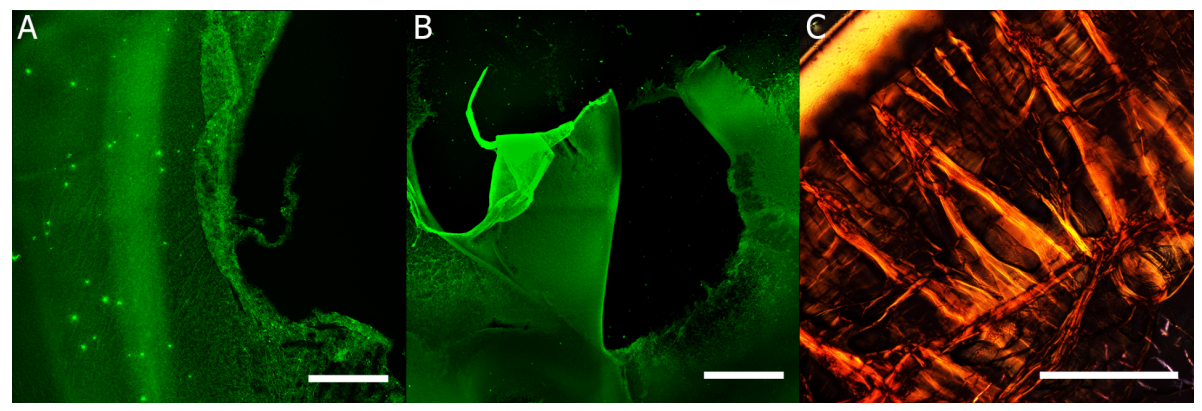

Figure S9.2. Collagen Type-I (from rat-tail) coated glass slides stained with (A) anti-col-I and (B) control probe and (C) picosirius red under polarized light. Both labels showed a high fluorescent intensity on the coating while there was no binding to the glass surface. In anti-col-I some fluorescent protein aggregates were found, which were not observed in the control probe. Scale bars represent $1 \mathrm{~mm}$.

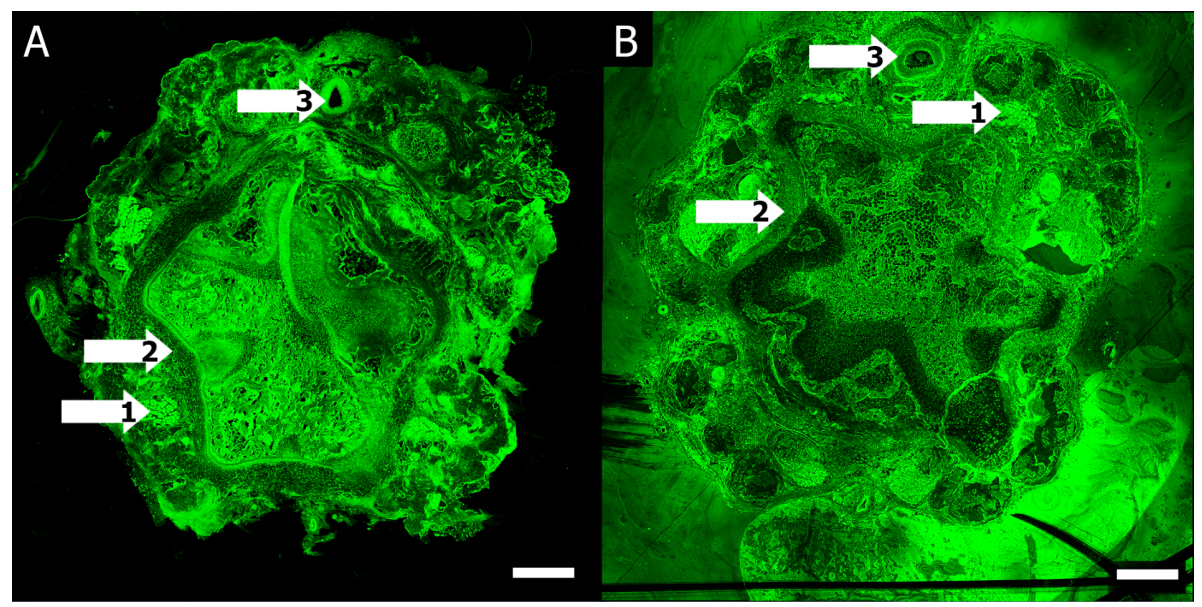

Figure S9.3. A demineralized $5 \mu \mathrm{m}$ thick cross-section of a rat-tail stained with (A) anticol-I and (B) control probe. In contrast to the collagen type-I coated glass slides, unspecific binding of the control probe to the glass slides was observed here. This difference could be caused by the fact that the glass-slides for histological sections were functionalized with a tissue adherence-promoting coating. The arrows indicate tendon tissue (1), periosteum (2) and the ventral artery (3). Suspected tendon-tissue showed a high fluorescent brightness with both probes. For the suspected ventral artery a higher fluorescent brightness was observed with the anti-col-I probe. Yet, the contrast in the tissue section for both probes is sufficient to distinguish between those different tissue types. The scale bar represents $1 \mathrm{~mm}$. 


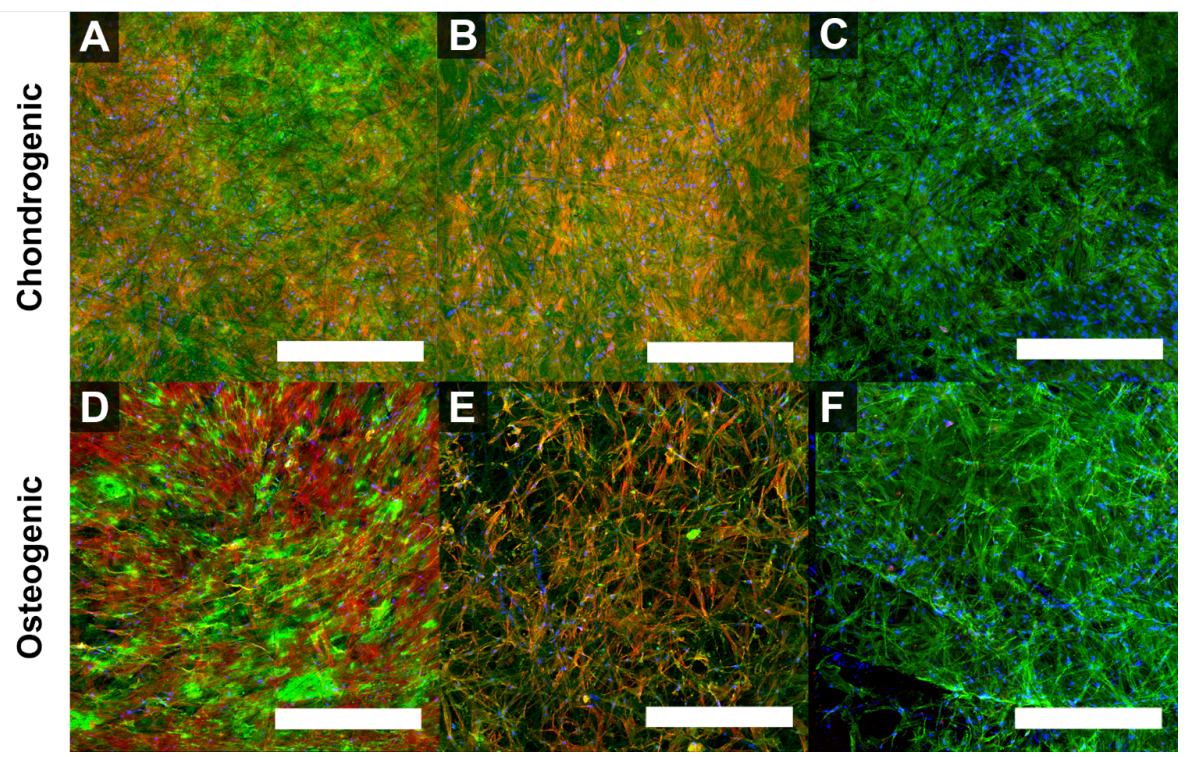

Figure S9.4. Stacked images of ES scaffolds seeded with hMSCs after 14 days of culture in osteogenic medium. DAPI staining (blue) was applied in all samples to identify the nuclei of the cells. (A, D) The control probe showed a relatively homogenous distribution of collagen staining (green) in chondrogenic medium compared to osteogenic medium in which highly fluorescent domains were found. (B, E) Anti-Col-I also showed a homogenous distribution of collagen staining in chondrogenic medium, while a lower amount of collagen staining was found in osteogenic medium although still homogeneously distributed. Actin filaments were stained red (Alexa Fluor 488) when collagen type-I was stained (A, B, D, E). (C, F) AntiCol-II (red) did not provide sufficient staining to monitor collagen type-II production. Only a few red spots were observed in both chondrogenic and osteogenic samples which could be caused by impurities in the sample or from the dye solution. In both conditions, confluence of the cells on the scaffolds could be observed. Scale bars represent $1 \mathrm{~mm}$. 


\section{Chapter 10}

\section{General Discussion}

Advances in the field of tissue engineering develop at a fast pace. However, nondestructive assessment of a potentially implantable construct remains a challenge. The need for novel approaches to monitor the quality of tissue engineered constructs with respect to cell adherence, proliferation, differentiation and tissue growth, among others, is well acknowledged $[1,2]$. The aim of this thesis was to assess this monitoring challenge from two sides. First, by evaluating cell fate in scaffold-based approaches by conventional destructive methods insights in the current state of these methods will be obtained. This evaluation may aid in the determination of scaffold properties that can be modulated without affecting cell-material interactions [3]. By changing these properties, the applicability of specific non-invasive monitoring methods could be increased. Second, the applicability of currently available imaging technologies on conventional scaffold-based tissue constructs was evaluated.

In chapter 2, we have reviewed recently reported efforts in developing and optimizing non-invasive methods to assess tissue growth, cell fate and scaffolds integrity in vivo and in vitro. Subsequently, we have evaluated the applicability of available imaging technologies on several scaffold materials and scaffold fabrication methods. From literature assessment, it can be concluded that to date destructive histological analysis remains the most applied method for the assessment of a tissue engineered construct, despite advances in the field of imaging in tissue engineering. The wide applicability of conventional histological analysis to distinct scaffold materials, geometries and tissue types is probably the main reason for these methods to remain the golden standard. For non-destructive imaging methods to become a standard, further advances in multi-modal imaging systems will be most promising [4]. By combining several imaging methods and advanced imaging processing algorithms, detailed information on various properties of the engineered constructs can be obtained [5]. To examine the potential of imaging approaches in assessing three dimensional (3D) tissue-engineered constructs, a model construct has to be developed and characterized by conventional methods as a control to validate the applied imaging approach. Part I of this thesis focused on the development and characterization of both conventional and novel scaffolding approaches. 


\section{Part I: Cell fate in 3D tissue engineered constructs}

A typical tenet in scaffold based tissue engineering strategies is the seeding of these porous biomaterials with a high cell number, especially for those scaffolds with a highly accessible and interconnected pore network like rapid prototyping ones. As cell expansion is associated with high costs and cumbersome procedures to obtain millions of cells for a scaffold, it is important to find optimized seeding conditions to reduce the amount of used cells without compromising tissue regeneration. Furthermore, during preliminary experiments on the monitoring of human mesenchymal stem cells (hMSCs) fate in 3D plotted polymeric scaffolds in vitro, the difficulty of poor cell adherence was faced. Therefore, in chapter 3 efforts to improve the initial cell adherence on these scaffolds by adjusting relatively simple cell seeding parameters without changing the scaffolds properties were reported [6]. It was shown that lower initial cell numbers and small cell seeding volumes can result in an increase in the cell seeding efficiency. When using clinically relevant cells such as hMSCs, the cell seeding conditions will have to be optimized per system and application to reduce cell loss without lowering the number of adhered cells on the scaffold.

Horizontal agitation did not improve the cell seeding efficiency compared to static culture in the study reported in chapter 3. However, other dynamic culture systems have shown to improve cell adherence and distribution [7-9]. Therefore, in chapter 4, a recently introduced dynamic culture system, by means of a biaxial rotating vessel, was utilized. The influence of the convection flow generated by the rotating vessel on cell adherence, cell fate and tissue growth was assessed for adult hMSCs and compared to fetal hMSCs. The biaxial rotating vessel bioreactor used in this study improved fetal hMSCs distribution and proliferation in 3D plotted PEOT/PBT scaffolds without inducing cell differentiation. Unfortunately, in our studies, these results could not be confirmed for two populations of adult hMSCs. Also a previously successfully applied perfusion bioreactor [10] showed detrimental effects on cell distribution and proliferation for adult MSCs. Yet, considering that bioreactor systems have been successfully used for more tortuous porous scaffolds for the culture of adult hMSCs [11, 12], it cannot be excluded that a further optimization of the operational parameters of the convection and perfusion bioreactors used in this thesis could aid the proliferation of adult MSCs on rapid prototyped scaffolds in future studies. The low cell number and poor cellular distribution in these studies with hMSCs could also be donor dependent. A higher number of hMSCs donors could eliminate this possible influence of donor variance [13].

In chapter 5, we introduced a novel bottom-up approach which ensures a homogenous cell distribution throughout the construct in static culture. We also examined the potential clinical translation of this approach. We showed how the physical properties of the micro-objects, which were developed as cell-laden spacers, influenced their cell-guided assembly. Besides fundamental experiments in which we showed the biocompatibility and tailorability of these objects, we also demonstrated the injectability of objects-cells aggregate suspensions for in situ tissue regeneration approaches. In preliminary follow-up studies conducted recently (data not shown in this thesis), we succeeded in the fabrication of these objects from already clinically applied biocompatible and biodegradable poly-lactic acid. Based on this result, we speculate that 
a library of scaffolding micro-objects can be developed in the near future to aid the controlled assembly of complex tissue engineered constructs both in vitro and in vivo. Moreover, we were able to sufficiently monitor cellular behavior over time to show the potential of our approach. In the future, we expect eventual imaging problems faced with this micro-object based approach to be less challenging than for the plotted polymeric scaffolds introduced in the chapters 3 and 4 . We base this hypothesis on the transparent properties of the micro-objects and the limited size of the injectable aggregates. Since so far no imaging challenges were encountered, this scaffolding approach was not further assessed in our experimental studies on the application of imaging modalities on tissue engineered constructs which were described in Part II of this thesis.

The possible donor variation observed in chapter 4 is slightly touched upon the study reported in chapter 6 , which aims at gaining insight in the differentiation capacity of several populations of hMSCs when cultured on 3D scaffolds. The stability of hMSCs differentiation induced by conventional delivery of soluble factors in the culture media was assessed on three types of polymeric scaffold and compared to their differentiation capacity in 2D. We showed that soluble-factor-induced differentiation was not impaired or improved by the properties of the scaffolds. We also showed that the differentiated phenotype of hMSCs in most conditions was lost upon soluble factor removal. Therefore, in future scaffold-based tissue engineering approaches the stability of the cellular phenotype has to be assessed prior to implantation to be able to better predict the clinical value of the construct.

In the near future, we think that gaining more real-time insights in cell behavior is of high importance for the success of tissue engineering approaches and the further development of promising instructive 3D constructs. We showed that in vitro differentiation of hMSCs on conventional synthetic scaffolds does not guarantee a stable differentiated phenotype. Many researchers focus on modulation of scaffold properties to better mimic the in vivo environment or to more effectively instruct cells into the desired lineage. Two of the main hurdles to overcome are a low reproducibility and donor dependent results. Therefore, most currently developed approaches remain inefficient since the quality of the obtained constructs can only be evaluated by sacrificing them. Therefore, even though a novel so called 'smart' scaffold might be highly promising for a certain tissue engineering approach, the evaluation of its clinical and commercial potential often remains a challenge when the successful application cannot be guaranteed.

\section{Part II: Challenges in imaging assessed}

In chapter 7, we have evaluated the application of three label-free Raman (micro-) spectroscopy set-ups on similar plotted scaffolds as previously introduced in chapter 3 , 4 and 5. In this study, we seeded bovine chondrocytes as a model cell line for cartilage tissue engineering research. However, we hypothesize that the same method for ECM characterization introduced here can also be applied on ECM produced by hMSCs. We showed that the detection of Raman bands 937 and $1062 \mathrm{~cm}^{-1}$ correspond to the presence of collagen and proteoglycans, respectively. By determination of the surface area of the peaks found, quantitative numbers on collagen and proteoglycan 
production were obtained. Previous works of co-workers on this chapter already showed the processing of the obtained Raman-spectra into images [14]. By applying confocal Raman micro-spectroscopy, detailed 3D color graphs or heat-maps could be reconstituted, which display spatial-local information on several ECM components within one model.

In chapter 8 , we have applied micro-magnetic resonance imaging on similar opaque plotted scaffolds as assessed in chapters 3,4 and 6. The focus in this study was to quantify total tissue formation, without specifically assessing the ECM composition. Therefore, the tests were run at scaffolds seeded with hMSCs and cultured in basic medium without differentiation inducing soluble factors and proliferation enhancing medium, which is basic medium supplemented with basic fibroblast growth factor. We introduced an image-processing procedure that allows for the quantitative analysis of the images, while correcting for imaging related artefacts such as inhomogeneous background illumination. Identified tissue distribution was quantified layer-by layer and visualized in 3D mesh models. We think that in the near future, optimized post-image processing sequences can result in shortening of required scanning times enabling multiple scans over time to monitor tissue growth almost continuously. Further advances will have to be made with respect to the practical use of MRI. Currently available devices have large dimensions and therefore will very likely not become a standard device in tissue engineering laboratories, even though recent advances are made in the development of smaller devices [15]. To further optimize the utilization of MRI in assessing tissue engineered constructs, MRI targeted contrast enhancing probes could be developed. Currently available targeted probes mostly rely on endocytosis or provide contrast in vascular systems by accumulation of high concentrations of magnetic beads $[16,17]$. By the development of specific ECM-component targeted contrast agents, via for example immunolabeling, non-invasive identification of these components in 3D opaque scaffolds or even in bioreactor systems could be achievable.

In chapter 9 , we exemplified the viability of this idea in theory and practice by a concise review on immunolabeling approaches followed by preliminary studies on the conjugation of fluorescent dyes to collagen type-I and type-II antibodies. Our results showed that the conjugation chemistry applied resulted in sufficient degrees of labeling. Yet, the binding affinity of the anti-collagen type-II probe seemed to be hampered. From the successful collagen type-I detection by the anti-collagen type-I probe in collagen coatings, native tissue and tissue engineered constructs, it can be concluded that the conjugation chemistry applied is efficient for this specific antibody. In this study, the fluorescent label served as a model for any other contrast enhancing agent for non-optical imaging processes. The conjugation chemistry is designed as such that the protocols do not require major modifications to be applicable on any other kind of label.

We expect that similar as in the field of medical imaging, the focus of microresolution non-invasive imaging will broaden with advances in the capabilities of the devices, the specificity of targeted labels and the introduction of complex algorithms in applied image processing. These improvements in combination with multi-modal imaging methods will significantly improve the quality and accuracy of the obtained information. In the past, improvements on imaging techniques were mainly focused on the hardware, for example by increasing the magnetic field strength in MRI or the 
introduction of confocal modalities in optical microscopes. In this thesis, we show that computational analysis of Raman spectra allows us to quantify extra cellular matrix components and that MRI image processing methods enable the quantification of tissue content in 3D. By combining the antibody conjugation approach introduced in chapter 9 with the advances in computational analysis of images and spectra, comprehensive information will be obtained which will ultimately aid in achieving higher efficiencies in any in vitro cultured tissue engineered construct.

\section{Concluding remarks}

From the results presented in this thesis, we believe that we have shown the importance and the potential of novel approaches to assess tissue engineered constructs. In the coming years, we expect the field to take a leap towards larger sized, more complex constructs in which the necessity to assess the functional composition of the construct will only increase. The field of tissue engineering is not solely materials and cell-based, but also comprises more often pharmaceuticals, growth factors, and other instructive elements. Clinical translation of such advanced tissue engineered constructs is expected to face more complex regulations, in which the quality and reproducibility of the constructs will be considered of even higher importance than in former applications. When non-invasive (multimodal) image- and sensor-based monitoring approaches would be combined into a single culture system, in which information can be analyzed on-line and consequently processes such as drug delivery can be actuated automatically, a higher control over cell and tissue fate could be achieved. One can imagine that ultimately, by direct and continuous monitoring and actuation of cell differentiation and tissue growth related processes, an increased efficiency and reproducibility of in vitro cultures could be achieved. 


\section{References}

[1] Materna T, Rolf HJ, Napp J, Schulz J, Gelinsky M, Schliephake H. In vitro characterization of three-dimensional scaffolds seeded with human bone marrow stromal cells for tissue engineered growth of bone: mission impossible? A methodological approach. Clinical oral implants research. 2008;19:379-86.

[2] Mather ML, Morgan SP, Crowe JA. Meeting the needs of monitoring in tissue engineering. Regenerative medicine. 2007;2:145-60.

[3] Wang X, Boire TC, Bronikowski C, Zachman AL, Crowder SW, Sung HJ. Decoupling polymer properties to elucidate mechanisms governing cell behavior. Tissue Eng Part B Rev. 2012;18:396404.

[4] Mouras R, Bagnaninchi PO, Downes AR, Elfick APD. Label-free assessment of adipose-derived stem cell differentiation using coherent anti-Stokes Raman scattering and multiphoton microscopy. Journal of Biomedical Optics. 2012;17.

[5] Baradez MO, Marshall D. The use of multidimensional image-based analysis to accurately monitor cell growth in 3D bioreactor culture. Plos One. 2011;6:e26104.

[6] Leferink AM, Hendrikson WJ, Rouwkema J, Karperien M, van Blitterswijk CA, Moroni L. Increased cell seeding efficiency in bioplotted three-dimensional PEOT/PBT scaffolds. Journal of tissue engineering and regenerative medicine. 2013:n/a-n/a.

[7] Grayson WL, Bhumiratana S, Cannizzaro C, Chao PH, Lennon DP, Caplan AI, et al. Effects of initial seeding density and fluid perfusion rate on formation of tissue-engineered bone. Tissue engineering. 2008;14:1809-20.

[8] Griffon DJ, Abulencia JP, Ragetly GR, Fredericks LP, Chaieb S. A comparative study of seeding techniques and three-dimensional matrices for mesenchymal cell attachment. Journal of tissue engineering and regenerative medicine. 2011;5:169-79.

[9] Katayama A, Arano T, Sato T, Ikada Y, Yoshinari M. Radial-flow bioreactor enables uniform proliferation of human mesenchymal stem cells throughout a three-dimensional scaffold. Tissue Eng Part C Methods. 2013;19:109-16.

[10] Janssen FW, Oostra J, Oorschot A, van Blitterswijk CA. A perfusion bioreactor system capable of producing clinically relevant volumes of tissue-engineered bone: in vivo bone formation showing proof of concept. Biomaterials. 2006;27:315-23.

[11] Di Maggio N, Piccinini E, Jaworski M, Trumpp A, Wendt DJ, Martin I. Toward modeling the bone marrow niche using scaffold-based 3D culture systems. Biomaterials. 2011;32:321-9.

[12] Stiehler M, Bunger C, Baatrup A, Lind M, Kassem M, Mygind T. Effect of dynamic 3-D culture on proliferation, distribution, and osteogenic differentiation of human mesenchymal stem cells. Journal of biomedical materials research. 2009;89:96-107.

[13] Siddappa R, Licht R, van Blitterswijk C, de Boer J. Donor variation and loss of multipotency during in vitro expansion of human mesenchymal stem cells for bone tissue engineering. Journal of orthopaedic research : official publication of the Orthopaedic Research Society. 2007;25:1029-41.

[14] Hilderink J, Otto C, Slump C, Lenferink A, Engelse M, van Blitterswijk C, et al. Label-Free Detection of Insulin and Glucagon within Human Islets of Langerhans Using Raman Spectroscopy. Plos One. 2013;8.

[15] Harrington JK, Chahboune H, Criscione JM, Li AY, Hibino N, Yi T, et al. Determining the fate of seeded cells in venous tissue-engineered vascular grafts using serial MRI. Faseb J. 2011;25:4150-61.

[16] Di Corato R, Gazeau F, Le Visage C, Fayol D, Levitz P, Lux F, et al. High-Resolution Cellular MRI: Gadolinium and Iron Oxide Nanoparticles for in-Depth Dual-Cell Imaging of Engineered Tissue Constructs. ACS Nano. 2013;7:7500-12.

[17] Xu C, Miranda-Nieves D, Ankrum JA, Matthiesen ME, Phillips JA, Roes I, et al. Tracking mesenchymal stem cells with iron oxide nanoparticle loaded poly(lactide-co-glycolide) microparticles. Nano Lett. 2012;12:4131-9. 


\section{Curriculum Vitae}

Anne Leferink was born on the 20th of January 1985 in Enschede, The Netherlands. She started her study Biomedical Engineering at the University of Twente in 2003 and completed her bachelor degree with a research project on the synthesis and characterization of photo-polymerizable materials for soft tissue engineering applications in the department of Polymer Chemistry and Biomaterials (PBM) under supervision of Prof. Dr. Dirk Grijpma. She continued with the master 'Molecular, Cellular and Tissue Engineering' and performed a four-months intership at the Institute for Biomedical Engineering (INEB, Porto, Portugal) on a project related to scaffold fabrication for the treatment of spinal cord injury under supervision

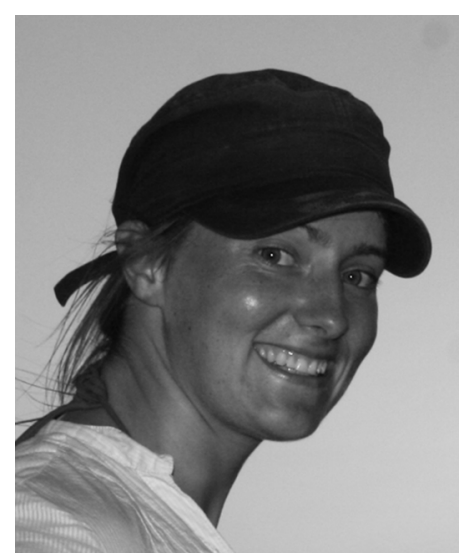
of Dr. Ana Paula Pêgo. In December 2009, she finished her master thesis entitled 'Design and fabrication of functionalized microstructures: fundamental studies on the role of physical parameters in cell-material interaction' which she performed at the Tissue Regeneration Department of the University of Twente (Prof. Dr. Clemens van Blitterswijk and Dr. Nicolas Rivron). In February 2010, she started her PhD research at the Department of Tissue Regeneration of the University Twente under supervision of Dr. Lorenzo Moroni and Prof. Dr. Clemens van Blitterswijk. Her research, of which the results are described in this thesis, was focused on monitoring tissue growth and cell behavior in three-dimensional scaffolds for bone and cartilage tissue engineering. 


\section{List of Publications}

\section{Peer-reviewed papers}

2014 A. M. Leferink, D. Schipper, E. Arts, E. Vrij, N. Rivron, M. Karperien, K. Mittmann, C. A. van Blitterswijk, L. Moroni and R. Truckenmüller. Engineered micro-objects as scaffolding elements in cellular building blocks for bottom-up tissue engineering approaches. Advanced Materials, 26(16), DOI: 10.1002/adma.201304539 2013 A. M. Leferink, W. J. Hendrikson, J. Rouwkema, M. Karperien, C. A. van Blitterswijk and L. Moroni. Increased cell seeding efficiency in bioplotted threedimensional PEOT/PBT scaffolds. Journal of TERM, DOI: 10.1002/term.1842

2013 A. Kunstar*, A. M. Leferink*, P. I. Okagbare, M. D. Morris, B. J. Roessler, C. Otto, M. Karperien, C. A. van Blitterswijk, L. Moroni and A. A. van Apeldoorn. Label-free Raman monitoring of extracellular matrix formation in three-dimensional polymeric scaffolds. Journal of the Royal Society Interface, 10(86). * shared first authorship

2012 K. Janeczek Portalska, A. M. Leferink, N. Groen, H. Fernandes, L. Moroni, C. A. van Blitterswijk and J. de Boer. Endothelial differentiation of mesenchymal stromal cells. PLoS One, 7(10):e46842.

\section{Manuscripts in preparation}

2014 A. M. Leferink, Y. Chng, C. A. van Blitterswijk and L. Moroni, A comparative study on cell distribution and viability of fetal and adult human bone marrow stromal cells in a biaxial rotating vessel bioreactor after seeding on polymeric $3 D$ rapid prototyped scaffolds. submitted

2014 A. M. Leferink, R. M. Fratila, M. A. Koenrades, C. A. van Blitterswijk, A.H. Velders, L. Moroni, An open source image processing method to quantitatively assess tissue growth after non-invasive magnetic resonance imaging in human bone marrow stromal cell seeded 3D polymeric scaffolds. submitted

2014 A. M. Leferink, D. Santos, M. Karperien, R. Truckenmüller, C. A. van Blitterswijk, L. Moroni, Differentiation capacity of human mesenchymal stromal cells cultured in three distinct types of $3 D$ polymeric scaffolds. submitted

2014 A. M. Leferink, D. Santos, C. A. van Blitterswijk, L. Moroni, An antibody based approach for multi-coloring osteogenic and chondrogenic proteins in tissue engineered constructs. in preparation 
2014 A. M. Leferink, M. P. Tibbe, C. A. van Blitterswijk, R. Truckenmüller, L. Moroni, A Novel approach for the fabrication of micro objects as cell spacers in regenerative medicine applications. in preparation

2014 A. M. Leferink, C. A. van Blitterswijk, L. Moroni, Review: Monitoring cell fate and tissue growth in three-dimensional scaffolds for tissue engineering. in preparation

\section{Abstracts selected for oral presentation}

2012 A. M. Leferink, R. Fratila, M. Karperien, C. A. van Blitterswijk, A.H. Velders and L.Moroni, Non-invasive imaging of stem cell fate and tissue development in $3 D$ scaffolds in vitro by MRI. NBTE, Lunteren, the Netherlands

2012 A. M. Leferink, M. Karperien, C. A. van Blitterswijk and L. Moroni, Differentiation and Dedifferentiation of $h M S C$ s in 3D. Biofabrication, Manchester, UK 2011 A. M. Leferink, W. J. Hendrikson, M. Karperien, C. A. van Blitterswijk and L. Moroni, Optimization of human mesenchymal stem cell seeding efficiency and spatial cell distribution on $3 D$ scaffolds fabricated by rapid prototyping. NBTE, Lunteren, the Netherlands

2011 A. M. Leferink, M. Karperien, C. A. van Blitterswijk and L. Moroni, Chondrogenic and osteogenic differentiation of hMSCs cultured on 3D PEOT/PBT scaffolds. TERMIS-EU, Granada, Spain

\section{Abstracts selected for poster presentation}

2013 A. M. Leferink, M. Karperien, C. A. van Blitterswijk and L. Moroni, Maintenance of multi- potential differentiation capacity of human mesenchymal stem cells on polymeric rapid prototyped 3D scaffolds. Till and McCulloch meeting, Banff, Canada 2012 A. M. Leferink, E. Arts, D. Schipper, N. Rivron, C.A. van Blitterswijk, L. Moroni and R. Truckenmüller, Directing aggregation of cells and microparticles as a bottom-up approach towards organized complex tissue constructs. NBTE, Lunteren, the Netherlands

2012 A. M. Leferink, D. Schipper, N. Rivron, C. A. van Blitterswijk, L. Moroni and R. Truckenmüller, Controlled aggregation of microstructures and hMSCs as a bottom-up approach towards cell and tissue organization. TERMIS-EU, Vienna, Austria

2012 A. M. Leferink, D. Schipper, N. Rivron, C. A. van Blitterswijk, L. Moroni and R. Truckenmuller, Controlled aggregation of microstructures and hMSCs as a bottom-up approach towards cell and tissue organization. $9^{\text {th }}$ World Biomaterials Conference, Chengdu, China

2010 A. M. Leferink, G. A. Higuera, M. Karperien, L. Moroni, C. A. van Blitterswijk, A one-point flow through oxygen sensor for monitoring cell behavior in $3 D$ constructs for tissue engineering applications. Biophysical stimuli and mass transport for tissue development, Lattrop, The Netherlands 